DOE/EIA-0206(95)

Distribution CategoryUC-950

\title{
Performance Profiles of Major Energy Producers 1995
}

January 1997

Energy Information Administration Office of Energy Markets and End Use U.S. Department of Energy Washington, DC 20585 


\section{Contacts}

This report was prepared in the Office of Energy Markets and End Use of the Energy Information Administration, U.S. Department of Energy, under the general direction of W. Calvin Kilgore. The project was directed by Mark E. Rodekohr, Director of the Energy Markets and Contingency Information Division (202) 586-1441, and Mary E. Northup, Chief of the Financial Analysis Branch (202) 586-1445. Kathy L. Washington performed the desktop publishing and formatting effort for this report.
Specific technical information concerning this report and the associated data survey (Form EIA-28), may be obtained from Jon A. Rasmussen (202) 586-1449. The following authors contributed to this report: Neal Davis (Chapters 4 and 5), Susanne Johnson (Chapters 4 and 5), Kevin Lillis (Chapters 1, 4, and 6), Jon Rasmussen (Executive Summary, Chapters 1, 2, 3, and 6), and Dennis Sumner (Chapter 2).

\section{Data File Information}

Historical Financial Reporting System (FRS) data are available from the Energy Information Administration's File Transfer Protocol (FTP) site and are also available on a 3.5-inch high-density diskette. These data cover the years 1977 through 1995, published in the Energy Information Administration's annual editions of Performance Profiles of Major Energy Producers. There are two different sets of data: aggregate data from the FRS survey form and multi-year tables from Appendix B of Performance Profiles of Major Energy Producers.

To download the Financial Reporting System 1977-1995 data files, access the Energy Information Center's FTP site, at ftp: / /ftp.eia.doe.gov or access the Energy Information Administration's Home Page at http://www.eia.doe.gov. For further assistance, please contact the National Energy Information Center at (202) 586-8800, FAX (202) 586-0727, TTY (202) 586-1181, or on INTERNET infoctr@eia.doe.gov.

To receive the Financial Reporting System 1977-1995 diskette, please contact Gregory P. Filas at telephone (202) 5861347, Fax (202) 586-9753, or on INTERNET gfilas@eia.doe.gov. 


\section{Preface}

This publication examines developments in the operations of the major U.S. energy-producing companies on a corporate level, by major line of business, by major function within each line of business, and by geographic area.

Pursuant to Section 205(h) of the Department of Energy Organization Act, which established the Financial Reporting System (FRS), the Energy Information Administration (EIA), through its Form EIA-28, collects financial information and other measures of energyrelated business efforts and results for major energy companies. Since the FRS data are collected on a uniform, segmented basis, the comparability of information across energy lines of business is unique to this reporting system. For example, petroleum activities can be compared to activities in other lines of energy business or nonenergy areas, and domestic activities can be compared to foreign activities.

This report presents financial and operating data collected on Form EIA-28 for the calendar year 1995. Trends in foreign direct investment in U.S. energy are analyzed for the year 1994.

In 1995, 24 companies filed Form EIA-28. The analysis and data presented in this report represent the operations of the FRS companies in the context of their worldwide operations and in the context of the major energy markets which they serve. Both energy and nonenergy developments of these companies are analyzed. Although the focus is on developments in 1995, important trends prior to that time are also featured.

Economic performance, in financial and physical dimensions, continues to serve as a significant factor in evaluating past decisions and guiding future options in the development and supply of energy resources. The information contained in this report is intended to promote an understanding and provide a critical review of the possible motivations and apparent consequences of investment decisions by some of the largest corporations in the energy industry. The information is intended for use by the U.S. Congress, Government agencies, industry analysts, and the general public. 



\section{Contents}

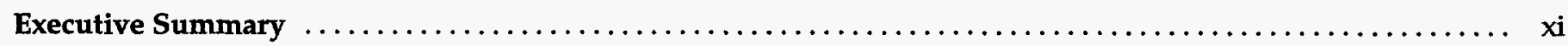

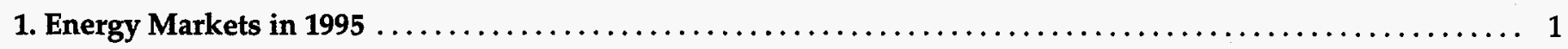

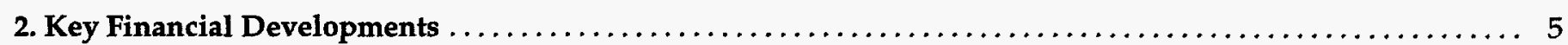

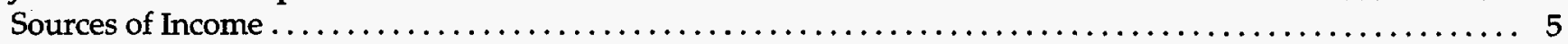

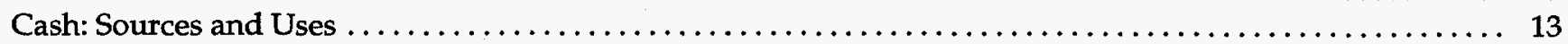

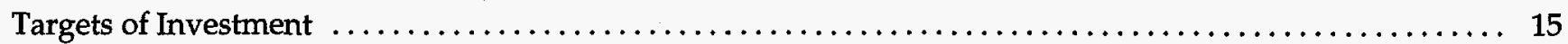

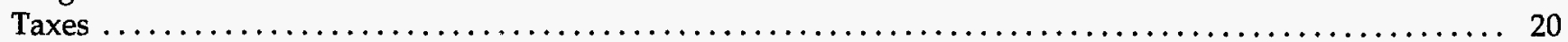

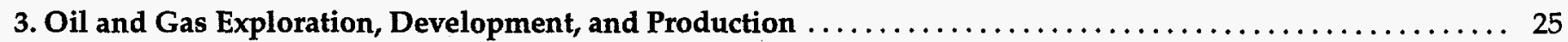

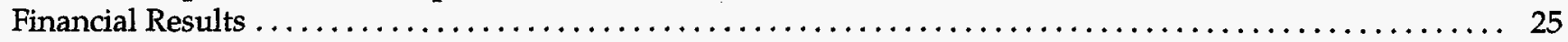

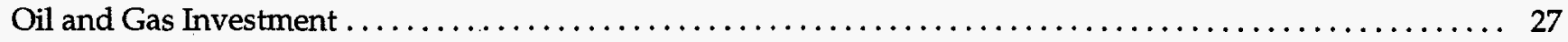

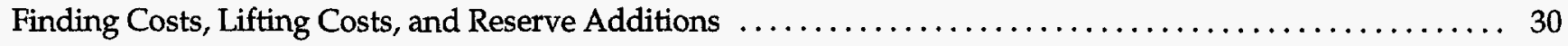

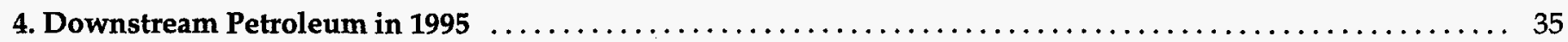

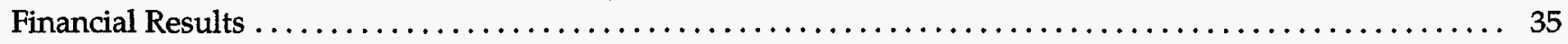

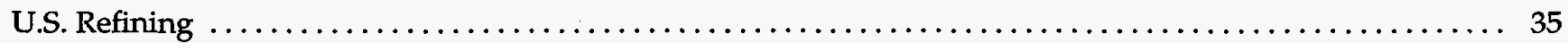

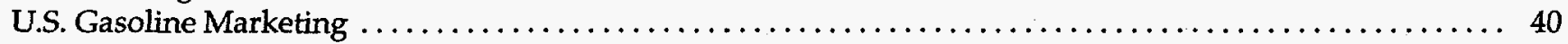

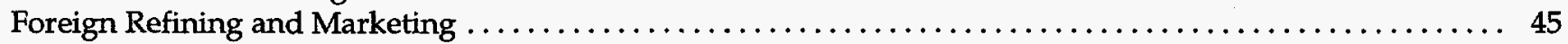

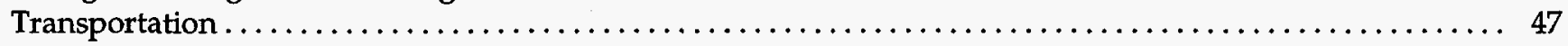

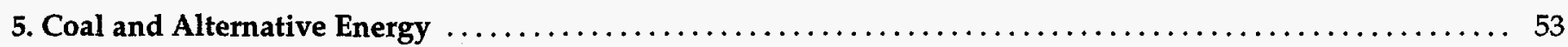

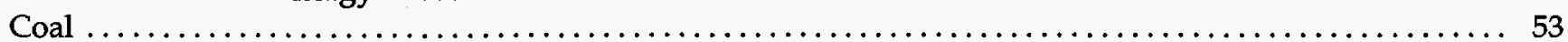

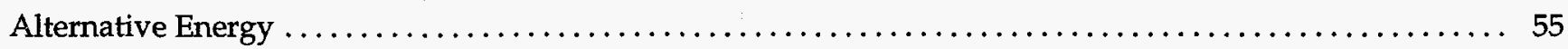

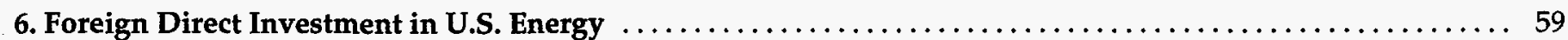

Foreign Acquisitions and Divestitures of U.S. Energy Assets $\ldots \ldots \ldots \ldots \ldots \ldots \ldots \ldots \ldots \ldots \ldots \ldots \ldots \ldots$

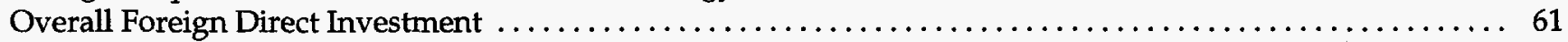

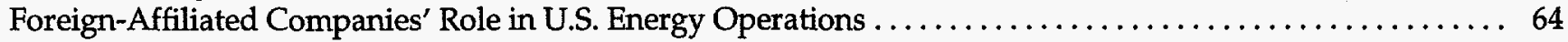

Financial Performance of Foreign-Affiliated Energy Companies $\ldots \ldots \ldots \ldots \ldots \ldots \ldots \ldots \ldots \ldots \ldots \ldots$

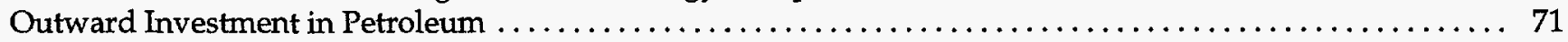

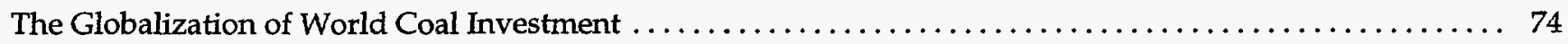

Appendices

A. Structure of the Financial Reporting System-Form EIA-28 $\ldots \ldots \ldots \ldots \ldots \ldots \ldots \ldots \ldots \ldots \ldots \ldots \ldots$

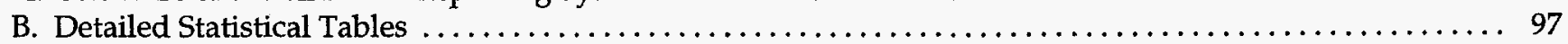

C. Completed Foreign Direct Investment Transactions, $1994 \ldots \ldots \ldots \ldots \ldots \ldots \ldots \ldots \ldots \ldots \ldots \ldots \ldots .155$

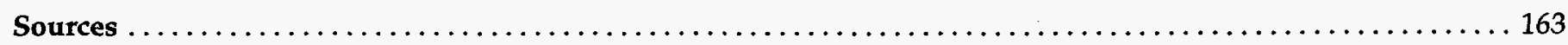

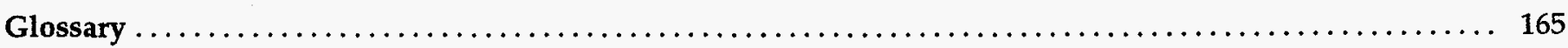




\section{Tables}

1. Consolidated Income Statement for FRS Companies, 1994 and $1995 \ldots \ldots \ldots \ldots \ldots \ldots \ldots \ldots \ldots \ldots \ldots \ldots$

2. Contributions to Net Income by Line of Business for FRS Companies, $1994-1995 \ldots \ldots \ldots \ldots \ldots \ldots \ldots \ldots$. . . . 8

3. Operating Income in Chemicals and Other Nonenergy Segments for FRS Companies, 1994-1995 .......... 9

4. Selected Financial Data for Petroleos de Venezuela and Other Large Multinational Petroleum

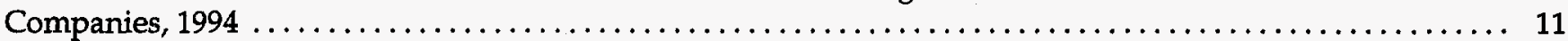

5. Return on Investment by Line of Business for FRS Companies, 1986-1995 ....................... 13

6. Line-of-Business Contributions to Pretax Cash Flow for FRS Companies, 1994-1995 . . . . . . . . . . . . . . . . . . . 14

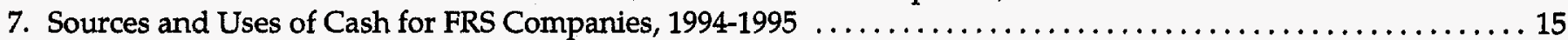

8. Additions to Investment in Place by Line of Business for FRS Companies, 1994-1995 . . . . . . . . . . . . . 17

9. Value of Mergers, Acquisitions, and Related Transactions by FRS Companies, $1995 \ldots \ldots \ldots \ldots \ldots \ldots \ldots \ldots$

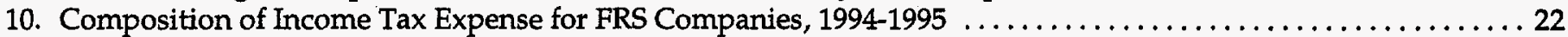

11. Income Tax Expense, Pretax Income, and Effective Tax Rates by Line of Business, 1994-1995 . . . . . . . . . . 23

12. Income Components and Financial Ratios in Oil and Gas Production for FRS Companies and

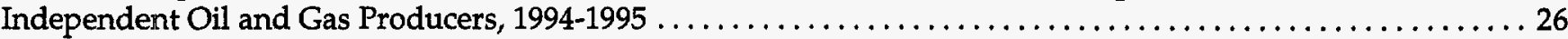

13. Average Prices, Sales, and Production in Oil and Gas for FRS Companies, 1994-1995 . . . . . . . . . . . . 27

14. Exploration and Development Expenditures for FRS Companies by Region, 1994-1995 .............. 28

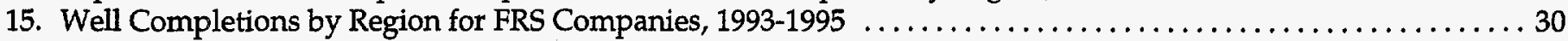

16. Finding Costs by Region, FRS Companies and Independent Producers, $1994-1995 \ldots \ldots \ldots \ldots \ldots \ldots \ldots \ldots$

17. Lifting Costs by Region, FRS Companies and Independent Producers, $1994-1995 \ldots \ldots \ldots \ldots \ldots \ldots \ldots \ldots \ldots$

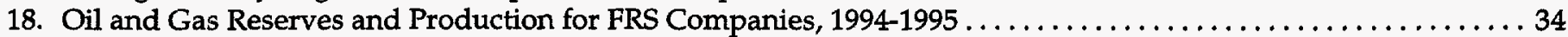

19. Refining and Marketing Investment and Operating Data for FRS Companies, 1994-1995 ............. 36

20. Sales, Expenses, and Income in U.S. Refining/Marketing for FRS Companies, 1994-1995 . . . . . . . . . . . . 36

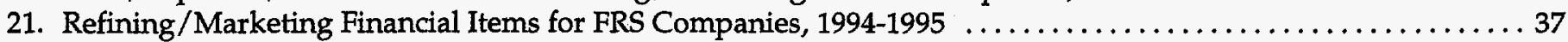

22. FRS U.S. Refined Product Margins and Costs per Barrel Sold, Selected Years, 1979-1995 . . . . . . . . . . . . 38

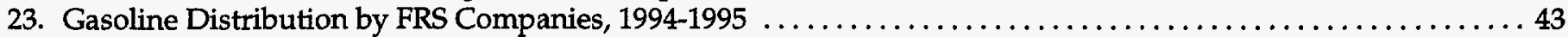

24. Marketing Characteristics and Refined Product Margin for FRS Companies Ranked by Total Energy Assets,

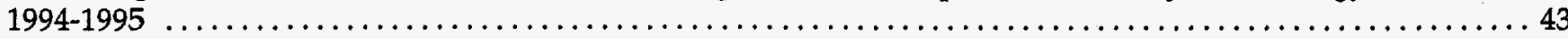

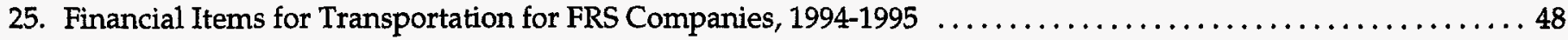

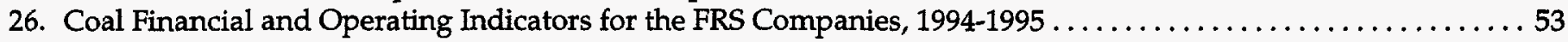

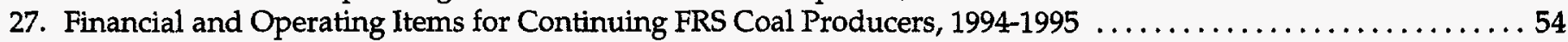

28. Revenues, Income, and Investment in Other Energy for FRS Companies, 1994-1995 . . . . . . . . . . . 55

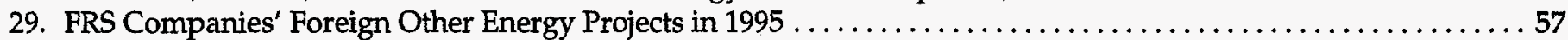

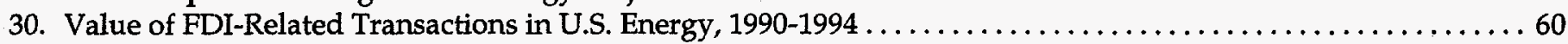

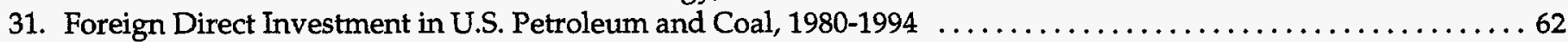

32. U.S. Capital and Exploratory Expenditures of Foreign-Affiliated Petroleum and Natural Gas Companies,

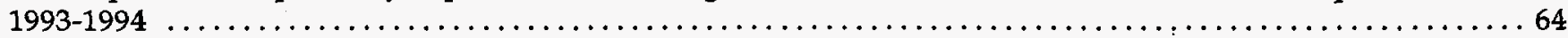

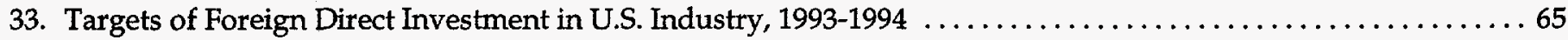

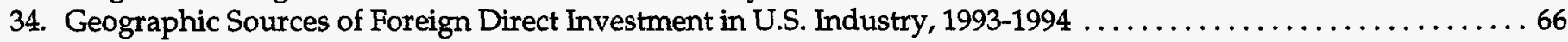

35. Geographic Sources of Foreign Direct Investment in U.S. Petroleum, 1993-1994 ...................667

36. Net Production of Petroleum and Dry Natural Gas in the United States by Foreign-Affiliated U.S. Companies,

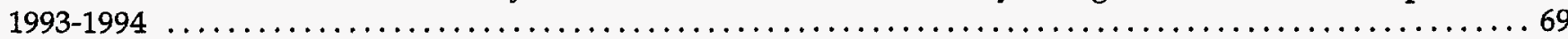

37. Domestic Oil and Dry Natural Gas Proved Reserves and Production for Foreign-Affiliated U.S. Companies,

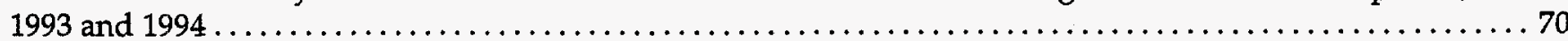

38. U.S. Refinery Operations of Foreign-Affiliated U.S. Companies, $1993-1994 \ldots \ldots \ldots \ldots \ldots \ldots \ldots \ldots \ldots \ldots 71$

39. Branded Retail Outlets and Total Gasoline Supplied by Foreign-Affiliated U.S. Companies, 1993-1994 . . . . . . . 72

40. Bituminous Coal and Lignite Production and Source of Ownership of Foreign-Affiliated Coal Companies

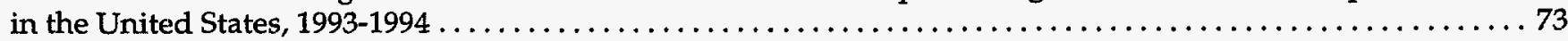

41. Foreign Participation in U.S. Uranium Exploration and Development, $1976-1994 \ldots \ldots \ldots \ldots \ldots \ldots \ldots \ldots$

42. Selected Financial Information for Foreign-Affiliated U.S. Energy Companies, 1993-1994 . . . . . . . . . . . . . 76

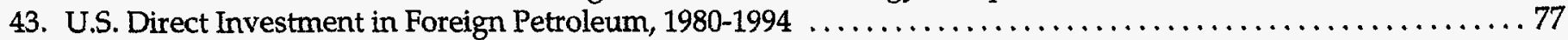

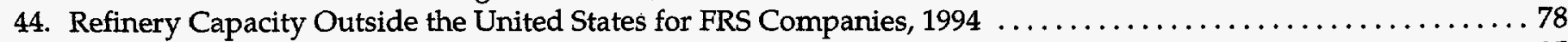

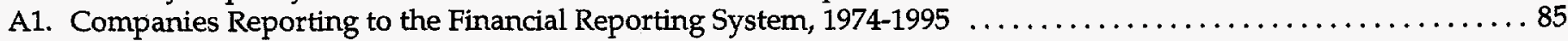

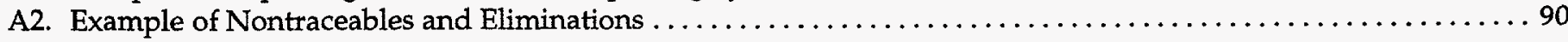


A3. A Comparison Between Full Cost and Successful Efforts Accounting Methods ..................93

A4. The Impact of FASB-52, Foreign Currency Translations, on Stockholders' Equity and Pretax Income,

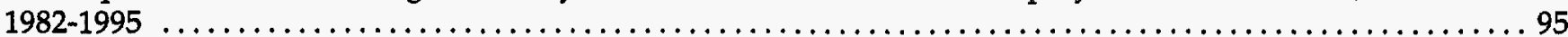

B1. Selected U.S. Operating Statistics for FRS Companies and U.S. Industry, 1994 and $1995 \ldots \ldots \ldots \ldots \ldots \ldots \ldots 9$

B2. Selected U.S. Operating Statistics for FRS Companies and U.S. Industry, $1989-1995 \ldots \ldots \ldots \ldots \ldots \ldots \ldots$. . . . . . 100

B3. A Comparison of Selected Financial Items for FRS Companies and the S\&P 400, 1995

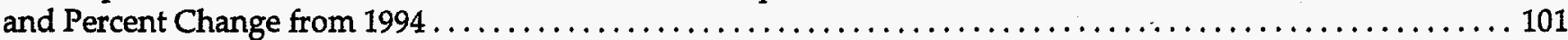

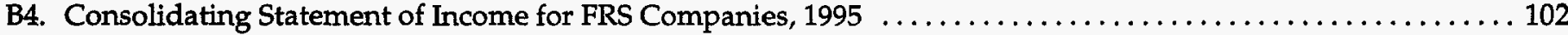

B5. Consolidating Statement of Income for FRS Companies, U.S. and Foreign Petroleum Segments,

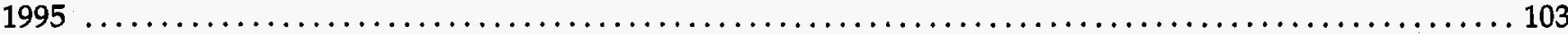

B6. Profit Rates for Lines of Business and Petroleum Segments for FRS Companies, 1989-1995 . . . . . . . . . . . 104

B7. Profit Rates for Petroleum Segments for FRS Companies Ranked by Total Energy Assets, 1993-1995

B8. A Comparison of Balance Sheet Items for FRS Companies and the S\&P 400, 1995 and

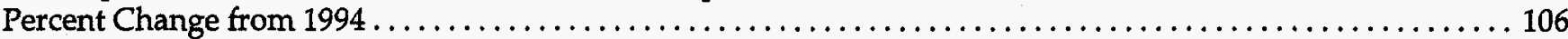

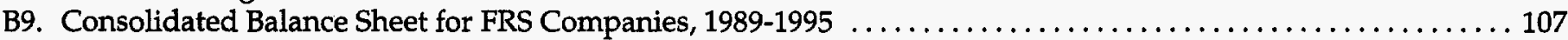

B10. Distribution of Net Investment in Place for FRS Companies, United States and Foreign, $1995 \ldots \ldots \ldots \ldots \ldots 108$

B11. Net Property, Plant and Equipment (PP\&E), Additions to PP\&E, Investments and Advances, and Depreciation, Depletion and Amortization (DD\&A), by Lines of Business for FRS Companies, 1995 . . . . . . . 109

B12. Income and Investment Patterns in Worldwide Petroleum for FRS Companies Ranked by Total Energy Assets, 1995, and Percent Change from 1994

B13. Income and Investment Patterns by Petroleum Segments for FRS Companies Ranked by Total

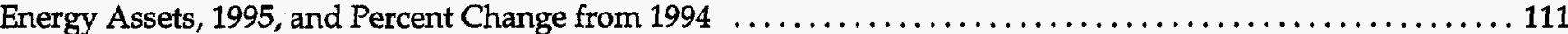

B14. Size Distribution of Income and Investment Within Worldwide Petroleum for FRS Companies

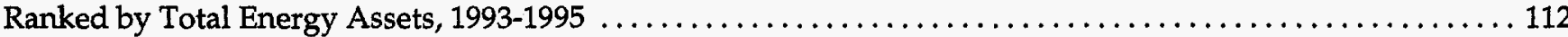

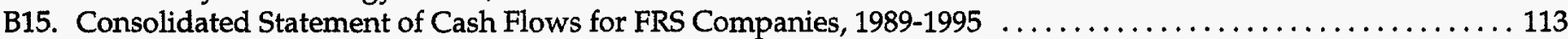

B16. A Comparison of Key Financial Indicators, Selected Performance Measures, and Patterns of Finance for FRS Companies and for the S\&P 400, 1993-1995 . . . . . . . . . . . . . . . . . . . . . . . . 114

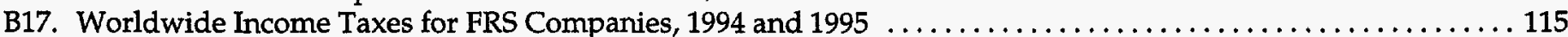

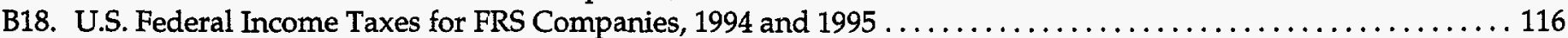

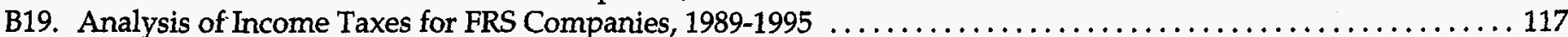

B20. U.S. Taxes Other Than Income Taxes for FRS Companies, 1995, and Percent Change from $1994 \ldots \ldots \ldots \ldots 118$

B21. Petroleum Exploration and Development Expenditures for FRS Companies, United States and

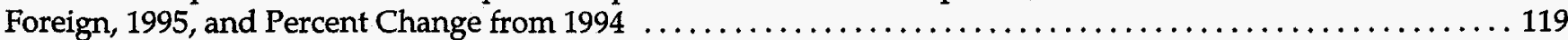

B22. U.S. and Foreign Exploration and Development Expenditures and Production (Lifting) Costs

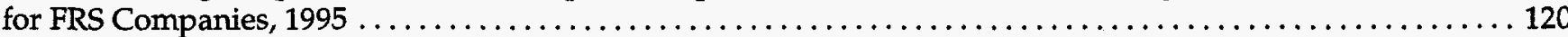

B23. Total Exploratory and Development Wells Drilled in the United States for FRS Companies and

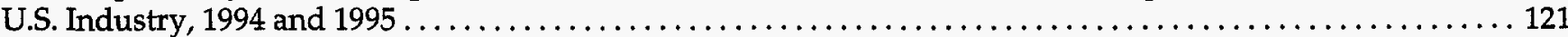

B24. Completed Well Costs, Oil, Gas, and Dry, for FRS Companies and U.S. Industry, 1994 and $1995 \ldots \ldots \ldots \ldots 122$

B25. Completed Well Costs, Oil, Gas, and Dry, Onshore and Offshore, for FRS Companies,

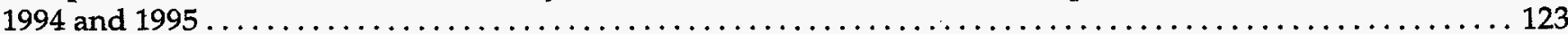

B26. U.S. Net Wells Completed, and Net In-Progress Wells for FRS Companies, 1989-1995 . . . . . . . . . . . . . . 124

B27. Exploration and Development Net Drilling Footage for FRS Companies, 1989-1995 . . . . . . . . . . . . . 125

B28. U.S. Net Producing Wells and U.S. Acreage for FRS Companies, 1989-1995 ...................... 126

B29. U.S. Net Petroleum Acreage for FRS Companies, Ranked by Total Energy Assets, 1995, and Percent Change from 1994 ...

B30. U.S. Net Ownership Interest Petroleum Reserves and Production for FRS Companies and

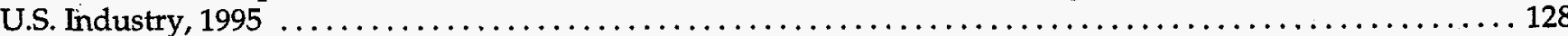

B31. Proved Petroleum Reserves for FRS Companies, United States and Foreign, 1995 . . . . . . . . . . . . . . . 129

B32. U.S. Reserve Additions, Exploration and Development Expenditures, and Expenditures per Barrel of Reserve Additions for FRS Companies Ranked by Total Energy Assets and for U.S. Industry, 1993-1995

B33. Foreign Petroleum Exploration, Development, Reserves, and Production Statistics by Geographic

Area for FRS Companies and Foreign Industry, 1995, and Percent Change from $1994 \ldots \ldots \ldots \ldots \ldots \ldots \ldots 131$

B34. Foreign Exploration and Development Expenditures by Region for FRS Companies, 1989-1995 .......... 132 
B35. Distribution of Foreign Exploration and Development Expenditures for FRS Companies Ranked

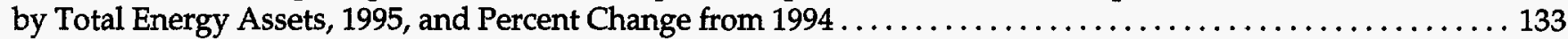

B36. Number of Net Wells Completed, Net In-Progress Wells, and Net Producing Wells in Foreign

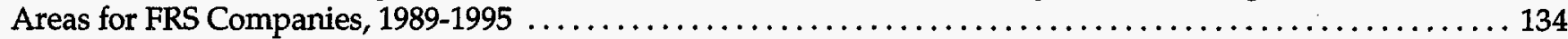

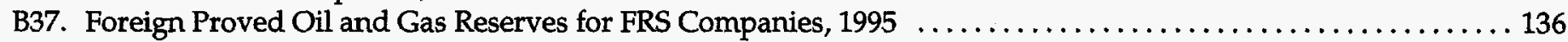

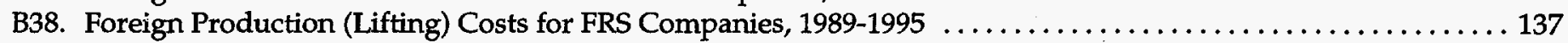

B39. U.S. Refining/Marketing Dispositions of Refined Products by Channel of Distribution for

FRS Companies, 1989-1995

B40. Sales of U.S. Refined Products, by Volume and Price, for FRS Companies Ranked by

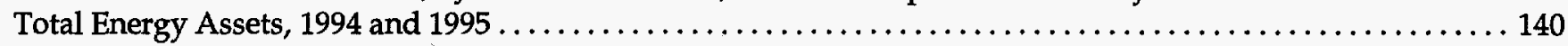

B41. U.S. Petroleum Refining/Marketing, General Operating Expenses for FRS Companies, 1989-1995 . . . . . . . . 141

B42. U.S. Petroleum Segments Purchases and Sales of Raw Materials and Refined Products for

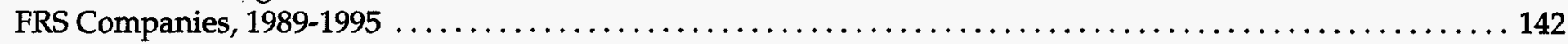

B43. U.S. and Foreign Refining/Marketing Segment, Sources and Dispositions of Crude Oil and

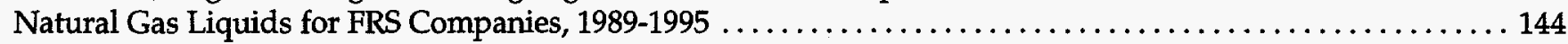

B44. U.S. and Foreign Oil Raw Materials Balance for FRS Companies Ranked by Total Energy Assets,

$1993-1995$.......................................................... 145

B45. U.S. Refinery Output and Refinery Capacity Statistics for FRS Companies, Ranked by

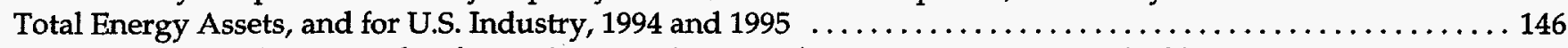

B46. Foreign Refinery Output and Refinery Capacity Statistics for FRS Companies, Ranked by

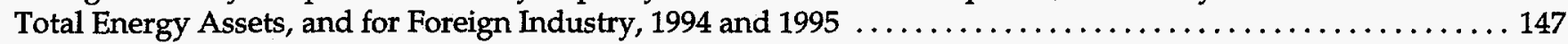

B47. U.S. and Foreign Petroleum Refining Statistics for FRS Companies, $1989-1995 \ldots \ldots \ldots \ldots \ldots \ldots \ldots \ldots \ldots$

B48. U.S. Refining/Marketing Revenues and Costs for FRS Companies, $1993-1995 \ldots \ldots \ldots \ldots \ldots \ldots \ldots \ldots \ldots$

B49. Sources of U.S. Bituminous Coal and Lignite Production, by Region and Mining Method,

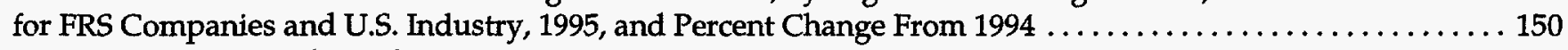

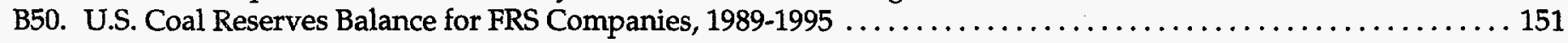

B51. U.S. Coal Reserves (End of Year) and Production Statistics for FRS Companies, 1989-1995 ............. 152

B52. Research and Development Expenditures for FRS Companies, $1989-1995 \ldots \ldots \ldots \ldots \ldots \ldots \ldots \ldots \ldots \ldots$

C1. Completed Transactions by Size in the Petroleum Industry from January 1994 Through

December 1994 -Acquisitions and Divestitures . . . . . . . . . . . . . . . . . . . . . . . . . . . . 157

C2. Completed Transactions by Size in the Coal Industry from January 1994 Through

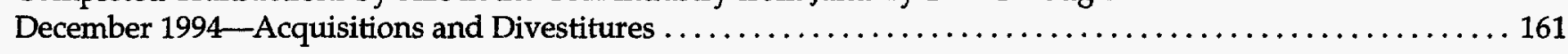

\section{Illustrations}

1. Operating Revenues by Line of Business for FRS Companies, $1981-1995 \ldots \ldots \ldots \ldots \ldots \ldots \ldots \ldots \ldots \ldots \ldots$

2. Shares of U.S. Energy Production and Refinery Capacity for FRS Companies, $1981-1995 \ldots \ldots \ldots \ldots \ldots \ldots . \ldots$

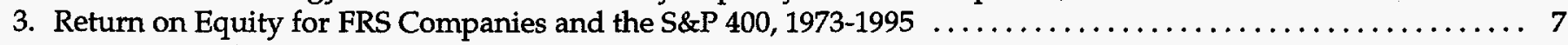

4. Revenues and Operating Expenses for the Chemical Segment for FRS Companies, 1981-1995 ........... 9

5. Return on Investment and Capital Expenditures on Chemicals for Companies, 1981-1995 . . . . . . . . . . . . 10

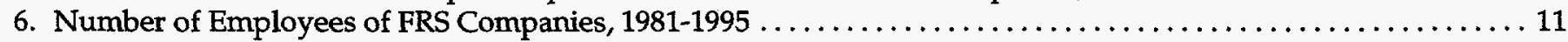

7. Research and Development Expenditures as a Percent of Cash Flow from Operations for FRS Companies,

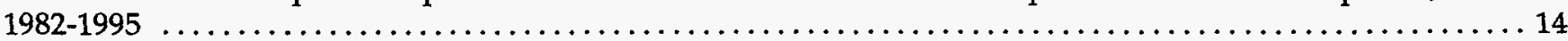

8. Research and Development Expenditures by Line of Business for FRS Companies, 1982-1995 ............ 14

9. Additions to Investment in Place and Value of Acquisitions and Mergers for FRS Companies, 1974-1995 . . . . 20 20

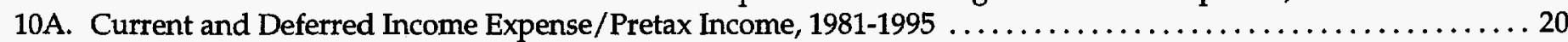

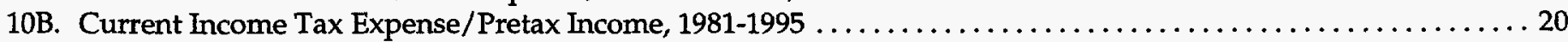

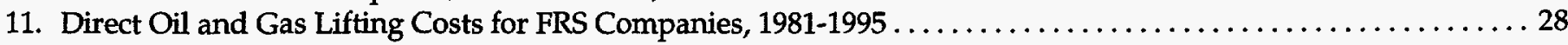

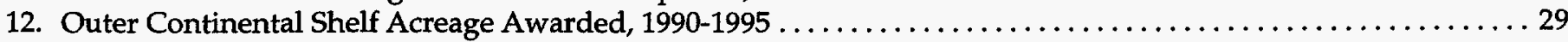

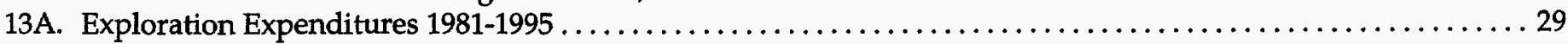

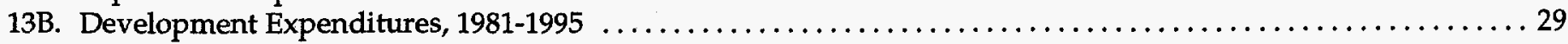

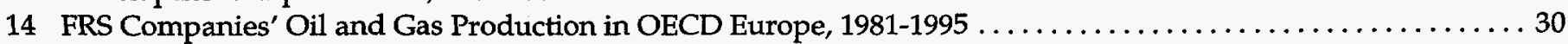

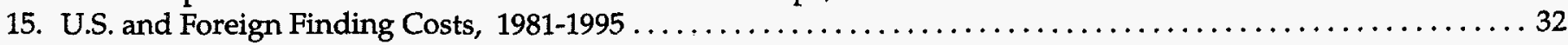

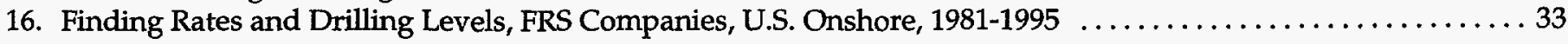




\section{DISCLAMMER}

Portions of this document may be illegible in electronic image products. Images are produced from the best available original document. 


\section{DISCLAIMER}

This report was prepared as an account of work sponsored by an agency of the United States Government. Neither the United States Government nor any agency thereof, nor any of their employees, make any warranty, express or implied, or assumes any legal liability or responsibility for the accuracy, completeness, or usefulness of any information, apparatus, product, or process disclosed, or represents that its use would not infringe privately owned rights. Reference herein to any specific commercial product, process, or service by trade name, trademark, manufacturer, or otherwise does not necessarily constitute or imply its endorsement, recommendation, or favoring by the United States Government or any agency thereof. The views and opinions of authors expressed herein do not necessar. ily state or reflect those of the United States Government or any agency thereof. 
17. FRS Company Return on Investment, 1990-1995

18. U.S. Refining Pollution Abatement Costs as a Share of Costs and Expenditures for the FRS Companies, 1977-1994

19. Net PP\&E per Unit of Refinery Capacity for the FRS Companies, 1974-1995

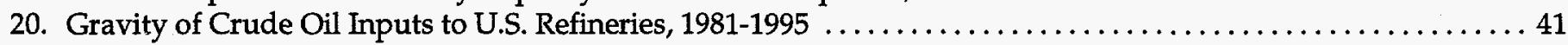

21. Average Sulfur Content of Crude Oil Inputs to U.S. Refineries, $1981-1995 \ldots \ldots \ldots \ldots \ldots \ldots \ldots \ldots \ldots \ldots \ldots$

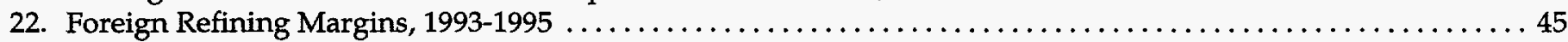

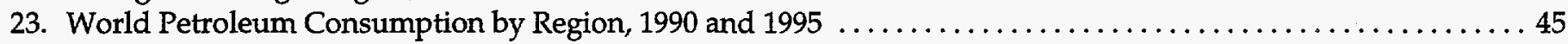

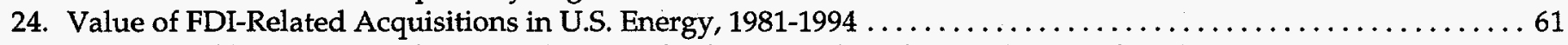

25. Foreign Affiliates' Share of U.S. Production of Oil, Gas, and Coal, and of U.S. Refining Capacity, 1980-1994 ... 68

26. Production and Share of U.S. Total Bituminous Coal and Lignite for Foreign-Affiliated U.S. Companies, 1980-1994

27. Foreign Capital and Exploratory Expenditures of the FRS Companies, 1974-1994 74

28. Exploration and Development Expenditures, by Foreign Regions, for FRS Companies, 1986, 1990, and 1994 ... 79 



\section{Executive Summary}

Performance Profiles of Major Energy Producers 1995 is the nineteenth annual report of the Energy Information Administration's (EIA) Financial Reporting System (FRS). The report examines financial and operating developments in energy markets, with particular reference to the 24 major U.S. energy companies required to report annually on Form EIA-28 (see Chapter 1, the box entitled "The FRS Companies in 1995"). Financial information is reported by major lines of business, including oil and gas production ("upstream"), petroleum refining and marketing ("downstream"), other energy operations, and nonenergy businesses. Financial and operating results are presented in the context of energy market developments with a view toward identifying changing corporate strategies and measuring the performance of ongoing operations both in the United States and abroad. Main developments in 1995 are described below.

\section{Financial Performance Highlights}

Net income and profitability of the FRS companies increased for the third consecutive year in 1995. Net income, excluding unusual items, increased 29 percent to $\$ 25.0$ billion from $\$ 19.3$ billion in 1994 . Income gains came primarily from chemical operations with foreign oil and gas production adding $\$ 1.7$ billion to bottom-line results. Cost-cutting continued to be evident in 1995, but downsizing appeared to lessen somewhat from the levels of prior years.

Cash flow generated by the FRS companies' operations reached a 10-year high in 1995. The rise in cash flow enabled the FRS companies to pursue additional investment, and to reduce debt to levels not seen since the early 1980 's, even while other large U.S. industrial companies were taking on added debt.

Oil and gas exploration and production was the leading target of energy-related investment in 1995. As in 1994, capital expenditures for U.S. oil and gas production outpaced expenditures for foreign oil and gas production. Growth in upstream spending reflected increased worldwide drilling by the FRS companies. The companies' focus on the drill bit paid off in 1995: for the second consecutive year, the FRS companies' worldwide oil and gas reserves added through exploration and development efforts were at a record high, exceeding their 1995 production by nearly 20 percent. Further, their costs of adding reserves were $\$ 4.18$ per barrel, the lowest level since at least 1977 (adjusted for inflation).

Two FRS company activities were especially notable in 1995. Natural gas markets grew in the 1990's, attracting heightened levels of exploration and development by FRS companies. The path to full deregulation of U.S. gas markets has attracted a number of FRS companies to activities beyond the wellihead, including trading, storing, and marketing of natural gas.

In contrast, U.S. refining and marketing activity has been a focus of retrenchment by a majority of FRS companies. Despite continued cost-cutting, the overall profitability of these operations went to near zero in 1995, the third lowest level in over 20 years of FRS data collection. The year 1995 may have seen the beginnings of a new response to low profitability: the pursuit of alliances involving downstream assets that could have substantial effects on costs, as well as on the competitive structure of refined product markets.

Another focus of the FRS companies' downsizing has been outlays for research and development, which have fallen in recent years in all categories of the companies' business activities.

\section{Demand Growth and Deregulation in Natural Gas}

The FRS companies have begun focusing investment on natural gas opportunities to take advantage of growth in demand in the United States and abroad. In the United States, demand for natural gas grew 15 percent from 1990 through 1995, compared to 5 percent for other forms of energy. Natural gas demand has grown in Europe and Asia, the regions accounting for most of the FRS companies' natural gas development and production outside North America. Demand growth in the AsiaPacific region has also encouraged a number of FRS companies to make sizable investments in natural gas production, and in the transportation of liquefied natural gas and natural gas liquids in this region. 
In 1995, the FRS companies drilled a record number of gas wells onshore in the United States. They added 6.2 trillion cubic feet of natural gas reserves onshore in the United States, also an FRS record. Their natural gas production in the United States was the highest since 1982, and their production in foreign regions was the highest since the nationalizations of the 1970's. The increased emphasis on natural gas is expected to continue, since the FRS companies' reserve replacement rates for natural gas generally exceed replacement rates for oil.

Deregulation of interstate natural gas transportation has opened new lines of enterprise in recent years. Federal Energy Regulatory Commission (FERC) Order 636 required the separate provision of natural gas transport services apart from other previously bundled services. This development has prompted the FRS companies to venture into the activities of resale, trade, and storage of natural gas. Resale activity by the FRS companies, as measured by the difference between U.S. natural gas sales and production, has grown nearly fourfold in the 1990's. In 1995, at least 12 FRS companies were involved in these midstream activities.

Natural gas is an attractive fuel for electrical generation, both for environmental reasons and because of the high thermal efficiencies achieved by gas-fired power plants. In the United States, nearly 50 percent of the growth in natural gas demand came from cogenerators, electric utilities, and other electric power producers in 1995. In the rapidly growing economies of Asia and Latin America, natural gas is an essential component of projected economic growth, including its use as an input to electric power production. As of 1995, a handful of FRS companies has made investments in gas-fired electric generation, mostly overseas, ${ }^{1}$ while several more FRS companies have recently shown varying degrees of interest in this line of activity.

\section{U.S. Refining and Marketing Results Hit Another Low}

In 1995, the financial performance of the FRS companies' U.S. downstream operations ${ }^{2}$ was the third poorest in at least two decades. In 1995, the squeeze on margins was in part due to the depressing effects of an unusually warm winter on first-quarter heating fuel demand and to complications arising from the introduction of reformulated gasoline in the first quarter.
In 1995, as in recent years, lower refining/marketing profitability has also in large part been the result of growing expenditures for refinery upgrades and pollution abatement. During the 1990's, the U.S. refining industry has invested billions of dollars in new conversion capacity. Much of this spending has been made in order to comply with the Clean Air Act Amendments of 1977 and the subsequent Clean Air Act Amendments of 1990. The year 1995 was the first full year of reformulated gasoline requirements. Investment in conversion capacity has enabled the U.S. refining industry to operate at record high utilization rates in recent years. However, the growth in conversion capacity has exceeded growth in demand for higher end products and in recent years has put downward pressure on both margins and earnings.

In the face of declining margins and higher environmental expenditures, FRS refiners have for several years been engaged in an effort to reduce the costs of operating their refineries and marketing networks. Although these efforts have largely been successful, they have been insufficient to reverse the slide in earnings. However, with most of the major investments required by .environmental legislation largely behind the U.S. refining industry, years of cost-cutting efforts may pay off in the future.

A more recent response to several years of declining margins and weak profitability has been the FRS companies' willingness to engage in joint downstream ventures with other companies. These agreements are attempts to further cut costs, rationalize operations, and restore the profitability of their petroleum product refining and marketing enterprises.

\section{A Wave of Downstream Alliances?}

Downstream agreements may prove to be the next stage after individual, company-based efforts to gain competitive rates of return in refining and marketing.

Recently, a number of FRS refiners announced agreements, still at the discussion stage at the time this report was being written, involving combinations of downstream assets. These efforts are apparently motivated by persisting low levels of profitability realized by refining operations in the United States and Western Europe throughout the 1990's. Cost savings is one possible motivating factor in all of these agreements, many of which (if not all) should result in labor force reductions.

\footnotetext{
${ }^{1}$ Energy Information Administration, Privatization and the Globalization of Energy Markets (DOE/EIA-0609) (Washington, DC, October 1996).

${ }^{2}$ As a group, the FRS companies represent a significant portion of the U.S. refining industry. In 1995, their operations accounted for 66 percent of total U.S. refining capacity.
} 
Also, regional concentration of marketing assets could relieve some competitive pressures on margins.

In the United States, Shell Oil, Texaco, and Star Enterprise (a 50-50 joint venture between Texaco and Saudi Arabia's Aramco) announced that they have been negotiating an alliance to combine their U.S. refining and marketing operations. To become a reality, an alliance must be successfully negotiated and subsequently approved by antitrust authorities. An example of the difficulties of achieving agreement was the discussion between DuPont's Conoco unit and Phillips Petroleum concerning a U.S. downstream joint venture which faltered. Nevertheless, Phillips indicated that it is still interested in a downstream joint venture. Also, Amerada Hess, another FRS company, announced a search for a downstream joint venture partner. Abroad, Mobil and British Petroleum announced their intent to merge their European downstream operations. Other FRS companies with agreements involving various European downstream assets include Conoco, Exxon, and Texaco.

Joint ventures involving downstream assets are not altogether new among FRS companies. For example,
Chevron and Texaco's Caltex joint venture has been operating in the Far East since the 1930's. In the United States, Shell Oil's Deer Park, Texas refinery is a 50-50 joint venture established in 1993 with Pemex, the state energy company of Mexico. What appears to be distinctive about the latest proposed downstream alliances is that they are primarily a response to low profitability of downstream assets in the United States and Western Europe.

Another area of recent joint venture activity, but generally not involving downstream assets, is oil and gas exploration and production in Venezuela. At least 12 FRS companies (including the foreign parent companies of BP America and Shell Oil) have been active in targeting Venezuela for future oil agreements with Petroleos de Venezuela (PDVSA), the state energy company of Venezuela, and its subsidiaries. To enable readers to better understand this development, and the likely partner of a number of FRS companies in future ventures in Venezuela, relevant aspects of PDVSA are reviewed in most of the chapters of this report. 


\section{Energy Markets in 1995}

The 24 major energy companies reporting to the Energy Information Administration's (ELA) Financial Reporting System (FRS) (see the box entitled "The FRS Companies in 1995 " on page 2) derive the bulk of their revenues and income from petroleum operations, including natural gas production (see the box entitled "The FRS Companies in the U.S. Economy and Energy Markets" on page 3). ${ }^{1}$ A majority of FRS companies are multinational, with over a third of their net investment located abroad. Worldwide petroleum and natural gas market developments are of primary importance to the FRS companies' financial performance. Developments in chemical markets are also important in that 16 FRS companies have asset commitments in chemical manufacturing.

A central tenet of energy market analysis is that economic growth is an important determinant of energy demand. World economic activity, as measured by inflationadjusted gross domestic product (GDP), was 2.2 percent higher in 1995 than in 1994. ${ }^{2}$ This rate of growth was roughly equal to the 1994 rate of world economic growth, although it was up significantly from the 0.7 -percent growth rates of 1992 and 1993.

The most rapidly growing area of the world encompasses the developing nations of the Asia-Pacific region, which registered an 8-percent growth rate in 1994 and 1995, nearly four times the average rate of economic growth experienced by the rest of the world. As a result, this region has been the main focus of the FRS companies' investments in refinery capacity and upgrading abroad in recent years. The Latin American economic expansion, which began in 1991, continued at a healthy pace, with the exception of Mexico, whose debt crisis precipitated a steep recession in 1995. In Africa, economic activity grew 2.7 percent in 1995, after growing 2.6 percent in 1994. The
United States economy began the year at a 3-percent rate of growth (year-over-year) in the first quarter; but by the fourth quarter of 1995, growth had slipped to a 1-percent rate. For the year, U.S. real GDP growth was 2 percent.

Judged by volatility of crude oil prices, oil markets were relatively quiescent in 1995 . Following the meeting of the Organization of Petroleum Exporting Countries (OPEC) in the Spring of 1994, which occurred in the context of the lowest oil prices since 1986, crude oil prices (as measured by the refiner's acquisition cost of imported crude oil) rose to the \$16-to \$17-per-barrel range. Apart from short-lived oil market disturbances in April and May, set off by U.S. sanctions on purchases of Iranian oil by U.S.-based companies, oil prices remained in the $\$ 16$ to $\$ 17$ range for the balance of 1995. On an annual basis, oil prices rose from $\$ 15.51$ to $\$ 17.14$ per barrel. Although oil supply and demand globally were in balance throughout 1995, regional shifts in supply and demand were evident.

World oil consumption in 1995 was up 1.6 percent over consumption the prior year. Most of the increase in oil demand came from the rapidly growing economies of Asia. In 1995, oil consumption in the Asia-Pacific region (which has recently become the world's second largest petroleum market after North America) was 4.4 percent higher than in 1994. Double digit crude oil consumption growth rates occurred in some of the most rapidly expanding Asian economies, such as China, Malaysia, the Phillippines, and Thailand.

Oil consumption also grew rapidly in Latin America, again with the exception of Mexico. Other geographic regions generally saw continued economic expansion and slightly higher petroleum consumption, with the exception of the economies of the Former Soviet Union. In

\footnotetext{
${ }^{1}$ The companies that reported to the FRS system for the years 1974 through 1995 are listed in Appendix A, Table A1. Three of the FRS companies are majority-owned by foreign companies: BP America-100-percent owned by British Petroleum, Fina-79-percent owned by Petrofina, and Shell Oil-100percent owned by Royal Dutch/Shell.

${ }^{2}$ In this chapter, international energy data were obtained from Energy Information Administration, International Energy Annual 1995, DOE/EIA0219(95) (Washington, DC, December 1996); international natural gas trade data were obtained from British Petroleum Company, p.l.c., BP Statistical Review of World Energy (London, June 1996); annual U.S. energy industry price and quantity data are from the Energy Information Administration, Annual Energy Review 1995, DOE/EIA-0384(95)(Washington, DC, July 1996); monthly data are from Energy Information Administration, Monthly Energy Review, DOE/EIA-0035(96/04) (Washington, DC, April 1996); GDP data are from the WEFA Group, World Economic Outlook (August 1996); and refining margin data are from the Energy Information Administration, U.S. Energy Financial Developments, 1995 First Quarter, DOE/EIA-0543(95/1Q) (Washington, DC, June 1995); offshore natural gas production data are from the Energy Information Administration, U.S. Crude Oil, Natural Gas, and Natural Gas Liquids Reserves 1995 Annual Report, DOE/EIA-0216(95) (Washington, DC, December 1996).
} 


\section{The FRS Companies in 1995}

\author{
Amerada Hess Corporation \\ Amoco Corporation \\ Anadarko Petroleum, Inc. \\ Ashland Oil, Inc. \\ Atlantic Richfield Company (ARCO) \\ BP America, Inc. \\ Burlington Resources, Inc. \\ Chevron Corporation \\ Coastal Corporation \\ E.I. du Pont de Nemours and Company \\ Enron Corporation \\ Exxon Corporation
}

\author{
Fina, Inc. \\ Kerr-McGee Corporation \\ Mobil Corporation \\ Occidental Petroleum Corporation \\ Oryx Energy Company \\ Phillips Petroleum Company \\ Shell Oil Company \\ Sun Company, Inc. \\ Texaco, Inc. \\ Union Pacific Corporation \\ Unocal Corporation \\ USX Corporation
}

the United States, oil consumption changed little between 1994 and 1995.

On the supply side, oil production was up 2.4 percent, largely due to increases in production among several nonOPEC producers. Notable among this group were Norway and the United Kingdom, with their North Sea production; Canada and Colombia in the Western Hemisphere; Angola in Africa; and India and Malaysia in Asia. These areas have been targets of exploration and development investments of the FRS companies during the 1990 's.

The one OPEC nation that showed a substantial increase in production was Venezuela, which (in violation of its OPEC quota) produced 162,000 barrels per day more in 1995 than in 1994 . U.S. oil production was nearly flat between 1994 and 1995, after declining at a 2 percent annual rate from its most recent peak in 1985 . Increased production from offshore locales just about offset oil production declines in Alaska and the lower-48 onshore. The FRS companies accounted for the increase in offshore production.

In spite of the general stability of crude oil prices in 1995, U.S. refiners experienced considerable turmoil and financial adversities. The year began with exceptionally mild temperatures (and reduced heating fuel demand) that left a high level of distillate inventories, a development which had a depressing effect on prices. Further, electric utilities' demand for residual fuel oil was low, in part because low natural gas prices in the first quarter of 1995 induced substitution of gas for heavy oil. Electric utilities also have been shifting away from fuel oil inputs for well over a decade. These first-quarter developments put a squeeze on U.S. refiners' price-cost margins, reducing them to a six-year low. In addition, petroleum markets in the United States were confronted with complications arising over the introduction of reformulated gasoline in the first quarter of 1995. Actions by several East Coast States to opt out of a voluntary system to adopt reformulated gasoline requirements led to an oversupply of reformulated gasoline. Although refiners' price-cost margins for the remainder of 1995 about matched those of the prior year, the financial results for all of 1995 bear the imprint of the first quarter's refining problems.

The path of U.S. natural gas prices in 1995 also reflected the weather-related developments of the first quarter. Wellhead prices were low until the overhang of natural gas stocks at the end of the relatively warm 1994-1995 heating season were worked off. The chilly onset to the new heating season late in 1995 produced an upswing in wellhead prices not seen since the prior December. For the year, U.S. wellhead prices were down 15 percent. Canadian natural gas prices were similarly affected, with the FRS companies reporting a 34-percent decline in their realized Canadian gas prices.

Outside North America, natural gas prices generally held up, with the FRS companies reporting a 5-percent rise in realized natural gas prices in Europe and elsewhere beyond North America. Stronger natural gas prices reflected the generally strong demand in the regions in which the FRS companies produce most of their natural gas; namely, Europe, with a 6.4-percent increase in natural gas consumption between 1994 and 1995, and Asia with a 7.2-percent increase. 


\section{The FRS Companies in the U.S. Economy and Energy Markets}

Major energy-producing companies annually report to the Energy Information Administration (EIA) on Form EIA-28 (Financial Reporting System). These reports include data and information on financial and operating developments. For the reporting year 1995, 24 companies filed this information. ${ }^{\mathrm{a}}$

The FRS companies occupy a major position in the U.S. economy. In 1995, their sales equaled 11 percent of the $\$ 4.5$ trillion in sales of the Fortune 500 largest U.S. corporations. ${ }^{c}$ Of the top 25 companies (based on sales) on the Fortune 500 list in 1995, 6 were FRS companies.

The reporting companies engage in a wide range of business activities, but their most important activities are in the energy sector. About 80 percent, or $\$ 396$ billion, of allocated operating revenues were derived from energy sales. Nearly all of these revenues were derived from the companies' core petroleum operations (Figure 1). (For purposes of this report, petroleum is defined to include natural gas.)

Figure 1. Operating Revenues by Line of Business for FRS Companies, 1981-1995

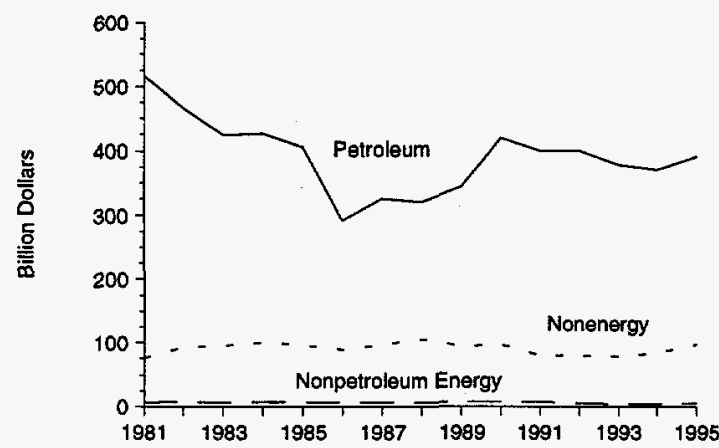

Note: Petroleum includes natural gas.

Source: Energy Information Administration, Form EIA-28.
In 1995, the FRS companies accounted for 52 percent of total U.S. crude oil and natural gas liquids (NGL) production, 45 percent of U.S. natural gas production, and 66 percent of U.S. refinery capacity (Figure 2). The bulk of the FRS companies' assets and new investments is devoted to sustaining various aspects of petroleum production, processing, transportation, and marketing. Nonenergy businesses, mainly chemicals, accounted for about 20 percent, or $\$ 96$ billion, of the FRS companies' allocated revenues in 1994.

Energy production other than oil and natural gas is a relatively small part of the FRS companies' operations. The combined operating revenues of coal and other energy operations of the FRS companies totaled $\$ 5$ billion in 1995, or only 1 percent of allocated revenues. Nonetheless, the FRS companies are significant participants in the coal market, producing 16 percent of U.S. coal in 1995. The FRS companies no longer produce uranium oxide domestically.

Figure 2. Shares of U.S. Energy Production and Refinery Capacity for FRS Companies, 1981-1995

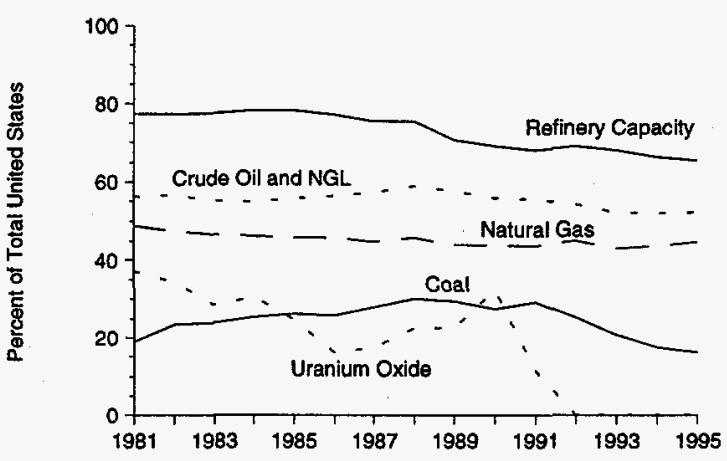

Source: Table B1 and Energy Information Administration Uranium industry Annual 1992 (October 1993).

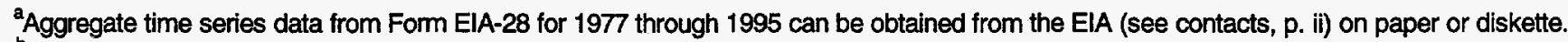

${ }^{b}$ For purposes of this report, the term "United States" typically includes the 50 States, the District of Columbia, Puerto Rico, and the U.S. Virgin Islands.

The Fortune 500 is a list of the 500 largest U.S. industrial companies, ranked by total sales, published annually by Fortune magazine. Prior to the 1994 listing, companies had to obtain a majority of their sales revenues from manufacturing/mining, including oil production and refining. That is, prior to 1994, only industrial companies were included. Among the top 25 U.S. industrial corporations (including Shell Oil) in 1993, 9 were FRS companies.
} 
In the 1990's so far, growth in demand for natural gas has far exceeded growth in demand for energy generally. This trend is expected to continue. Only a small portion of natural gas is traded internationally (roughly 15 percent) and the countries of the Former Soviet Union (which export natural gas to Europe) and Canada (which exports natural gas to the United States) account for two-thirds of the international trade in natural gas. North America and Europe constitute the world's largest natural gas markets. In contrast to the recent trends in crude oil consumption, some of the most rapid growth in natural gas consumption has occurred in developed countries.

The manufacture of a wide variety of chemical products is an important source of income for a majority of the FRS companies. Chemical manufacturers experienced the best backto-back years of demand growth since 1987 to 1988 . Not only did demand for chemicals grow in both 1994 and 1995, but nearly all FRS companies with chemical operations reported higher price-cost margins in 1994 and again in 1995. However, demand growth flattened in late 1995 and, based on past patterns, chemical earnings in 1996 could fall precipitously.
This report reviews the FRS companies' 1995 financial performance and corporate strategies in the context of domestic and foreign energy market developments. Chapter 2 presents an overview of sources of income, cash flow, taxation, and deployment of funds, including FRS company investment patterns across their lines of business. Chapter 3 reviews the FRS companies' performance in oil and gas exploration, development, and production from a global perspective. Chapter 4 examines developments in the FRS companies' refining, marketing, and transport activities.

Chapter 5 reviews the FRS companies involvement in energy sources other than petroleum and natural gas. Chapter 6 presents a summary of foreign direct investment in U.S. energy ${ }^{3}$ which, in prior years, was published separately in the Profiles of Foreign Direct Investment in U.S. Energy report. The coverage of foreign direct investment developments discussed in this chapter lags the discussion of the FRS companies by one year. This is due to the later release date of much of the foreign direct investment data. Appendix A describes the structure of the FRS data collection system, and Appendix B presents detailed statistical tables. Appendix C lists transactions related to foreign direct investment in U.S. energy. A glossary provides key definitions.

\footnotetext{
${ }^{3}$ The purpose of this report is to provide an assessment of the degree of foreign ownership of energy assets in the United States. Section 657 , Subpart 8 of the U.S. Department of Energy Organization Act (Public Law 95-91) requires an annual report to Congress which presents: "...a summary of activities in the United States by companies which are foreign owned or controlled and which own or control United States energy sources and supplies..."
} 


\section{Key Financial Developments}

\section{Sources of Income}

In 1995, the financial performance of the 24 major energy companies reporting to the Energy Information Administration's Financial Reporting System (FRS) improved for the third consecutive year. Income gains came primarily from chemical operations. Foreign oil and gas production added importantly to bottom-line results as well. Costcutting continued to contribute to earnings in 1995, but the pace of downsizing of company operations moderated somewhat from downsizing in recent years. In 1995, a new accounting standard resulted in substantial one-time charges against income (see the box entitled "New Accounting Standard Leads to Billions in Asset Writeoffs" on page 6). Consequently, discussions of income exclude the effects of unusual items. ${ }^{4}$

Net income of the FRS companies increased 29 percent to $\$ 25.0$ billion (excluding unusual items) from $\$ 19.3$ billion in 1994 (Table 1). The overall profitability of the FRS companies, as measured by return on equity, reached a five-year peak in 1995 (Figure 3). Return on equity for other large U.S. industrial companies' slipped a bit but was second only to 1994's record level. ${ }^{5}$

\section{Chemicals and Foreign Upstream Lead to Higher Profits}

Nonenergy operations accounted for 82 percent of the gain in net income (excluding unusual items) allocated to all lines of business in 1995 (Table 2). ${ }^{6}$ The nonenergy line of business is dominated by chemical operations which accounted for the bulk of the FRS companies' gain in net income in 1995. This development was a reprise of financial performance patterns in 1994, when chemical operations also led to an upswing in overall earnings. In 1994 and 1995, the chemical sector experienced its two strongest back-to-back years since the 1987 to 1988 period, although the pace of demand growth fell off in the latter months of $1995 . .^{8}$ The FRS companies' performance reflected this buoyancy. All 16 FRS companies with chemical operations reported improved income from chemicals. Ashland, Exxon, and Occidental Petroleum reported all-time record earnings for their chemical businesses in 1995. All 16 companies also reported improved price-cost margins, largely due to increased demand in key lines of chemical activity. Figure 4 illustrates that the growth in chemicals income (Table 3) was driven by revenue growth.

Despite the recent surges, chemical earnings may fall off noticeably if past patterns are an accurate indication. For example, from 1989 to 1993, domestic chemical demand, as measured by the industrial production index, grew 6 percent. Yet the profitability of FRS companies' chemical operations over the same time period plunged. Figure 5 shows that the FRS companies' capital expenditures for chemicals closely follow upswings in profitability. Thus, it appears that chemical investment, and associated increases in capacity, respond rapidly to positive profit signals. On a worldwide basis as well, growth in capacity also tends to rapidly follow demand increases. Consequently, when demand growth falls or turns negative, as

\footnotetext{
4Unusual items are composed of gains and charges recognized in a company's income statement that are of a non-recurring nature and generally unrelated to current operations. These items include effects of accounting changes, litigation settlements, gains and losses from large divestitures of assets, provisions for the cost of restructuring, and provisions of reserves for future liabilities.

'The Standard and Poor's 400 (S\&P 400) Industrial Corporations is a well recognized database that includes 400 of the largest U.S. industrial companies. In 1995, 19 of the FRS companies were included in the S\&P 400. Financial statistics for the S\&P 400 were obtained by accessing Compustat, a service of Standard \& Poor's, Inc.

${ }^{6}$ Excluding unusual items, total allocated income rose from $\$ 24.5$ billion in 1994 to $\$ 31.2$ billion in 1995 , a gain of $\$ 6.6$ billion (or 27 percent). Of this gain, $\$ 5.4$ billion, or 82 percent, was due to the 76-percent rise in nonenergy net income.

${ }^{7}$ For FRS purposes, separate reporting of income for chemical and other nonenergy segments was discontinued beginning with the 1987 reporting year. However the disclosures of chemical segment revenues and operating income made by the FRS companies in their annual reports to shareholders closely track in the aggregate, comparable disclosures in the Form EIA-28 from 1981 through 1986. Thus the public disclosures of chemical segment revenue and operating income were utilized for 1987 through 1995. Revenues and operating income for the other nonenergy segment after the 1986 reporting year were obtained by subtracting the publicly disclosed chemical segment values from the nonenergy line-of-business values reported on Form EIA-28. It should be noted that the results for chemicals are qualitatively unchanged if DuPont, the largest FRS chemical producer, is excluded.

${ }^{8}$ Economic Report of the President (February 1996), pp. 336, 352.
} 


\section{New Accounting Standard Leads to Billions in Asset Writeoffs}

The financial statements of publicly-traded U.S. corporations are prepared in accordance with generally accepted accounting principles, including the standards set forth by the Financial Accounting Standards Board (FASB). The FASB issued Statement no. 121 "Accounting for the Impairment of Long-Lived Assets and for Long-Lived Assets to be Disposed Or'(SFAS 121) in March 1995. The Statement is effective for fiscal years beginning after December 15, 1995, with earlier implementation encouraged. In general terms, SFAS 121 involves reviewing long-lived assets, certain identifiable intangibles and goodwill related to those assets to be held and used, and long-lived assets and certain identifiable intangibles to be disposed of to determine whether they have become impaired. For purpose of SFAS 121, impairment occurs whenever the carrying amount of these assets can not be recovered. If, based on facts and circumstances, recovery is questionable, impairment testing should be done by estimating future undiscounted cash flows from the asset's use and eventual disposition. If the undiscounted future cash flow equals or exceeds the asset's carrying amount, it is not considered impaired for purposes of SFAS 121 and no further testing is required. However, if the future undiscounted cash flow from the asset's use and eventual disposition is less than the carrying amount of the asset, then a loss equal to the difference between the asset's estimated fair market value and carrying amount is recorded.

Of particular importance to the oil and gas industry is the requirement that assets be grouped and tested "at the lowest level for which there are identifiable cash flows that are largely independent of the cash flows of the groups of assets." Prior to SFAS 121, most oil and gas entities grouped their oil and gas assets for impairment testing in large groups such as by country or continent. By using this grouping method, fields whose future undiscounted cash flows exceeded their carrying amount could be grouped with fields which did not meet the test, thereby avoiding a writedown. For example, a company with a producing field in California whose expected undiscounted future cash flow exceeded the field's asset, carrying value by $\$ 50$ million could group it with a field in Louisiana whose expected future undiscounted cash flow is $\$ 20$ million less than the field's asset carrying value. Since the combined estimated undiscounted future cash flow from the two fields exceeded their combined carrying amount by $\$ 30$ million, no writedown was required. However, under SFAS 121 the two fields would be tested separately. Under SFAS 121, the California field would not be a candidate for a writedown; however, the Louisiana field's fair market value would need to be determined because its estimated future cash flow is less than its carrying amount. Assuming the Louisiana field's fair market value was $\$ 25$ million less than its asset carrying value, the company would be required to record a $\$ 25$ million asset impairment provision in its financial statement.

Although companies were not required to implement SFAS 121 until the first quarter of 1996, 16 of the 24 FRS reporting companies announced their adoption of the standard during 1995. These companies recorded writedowns of $\$ 5,966$ million pretax, $\$ 4,088$ million after tax. The after-tax provision was recorded in the following industry segments: $\$ 2,732$ million to domestic production; $\$ 539$ million to domestic refining and marketing; $\$ 442$ million to foreign production; $\$ 172$ million to coal; $\$ 82$ million to other nonenergy; $\$ 64$ million to nontraceable; $\$ 25$ million to international marine; $\$ 18$ million to chemicals; and $\$ 8$ million to pipelines. The eight companies which chose to wait until 1996 to implement the standard all reported its implementation would not have a significant impact on their 1996 financial statements.

in the recession of 1991, the chemical industry finds itself with excess capacity and consequent downward pressures on prices, margins, and profitability. Until the next uptick in demand growth, profits will likely be depressed.

Although the FRS nonenergy line of business is dominated by chemical activity, other nonenergy enterprises also contributed to earnings growth in 1995 (Table 3). A minority of companies continue to have a significant asset commitment to activities outside the core areas of energy and chemicals. The height of the majors' involvement in other nonenergy was shortly after crude oil prices peaked in 1981. In 1983, a year after DuPont and USX (then US Steel) entered the ranks of the FRS companies through mergers with Conoco and Marathon Oil, respectively, 20 FRS companies reported assets in the other nonenergy line of business and 13 percent of the FRS asset base was allocated to diversified activities beyond energy and chemicals. Beginning in 1984, diversified businesses became targets of restructuring and divestiture. By 1995, 
Table 1. Consolidated Income Statement for FRS Companies, 1994 and 1995

(Billion Dollars)

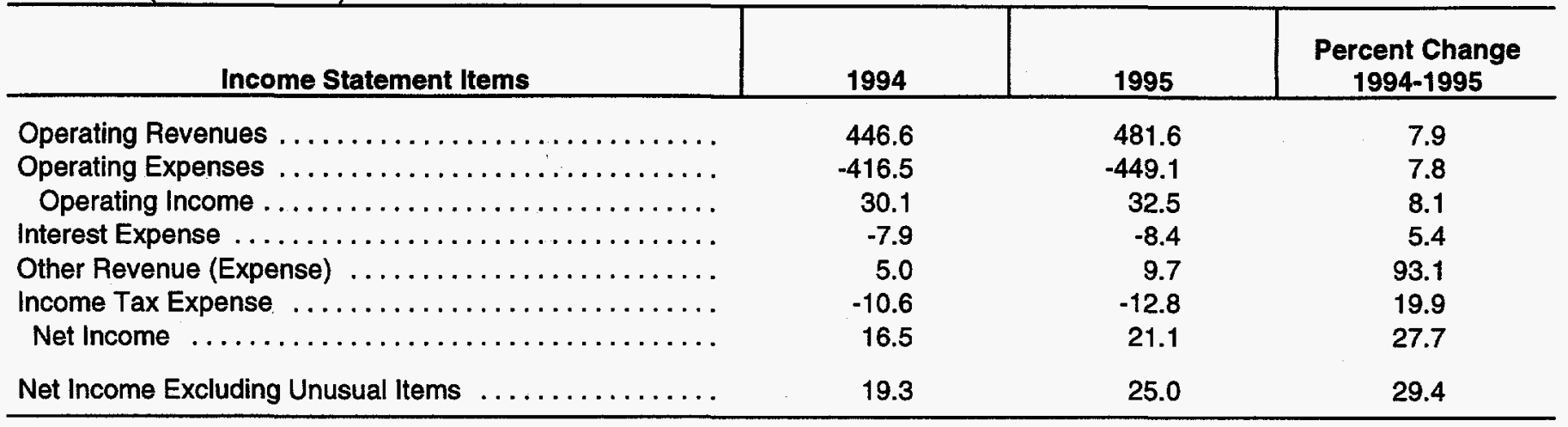

Note: Sum of components may not equal total due to independent rounding. Percent changes were calculated from unrounded data.

Source: Energy Information Administration, Form EIA-28.

Figure 3. Return on Equity for FRS Companies and the S\&P 400, 1973-1995

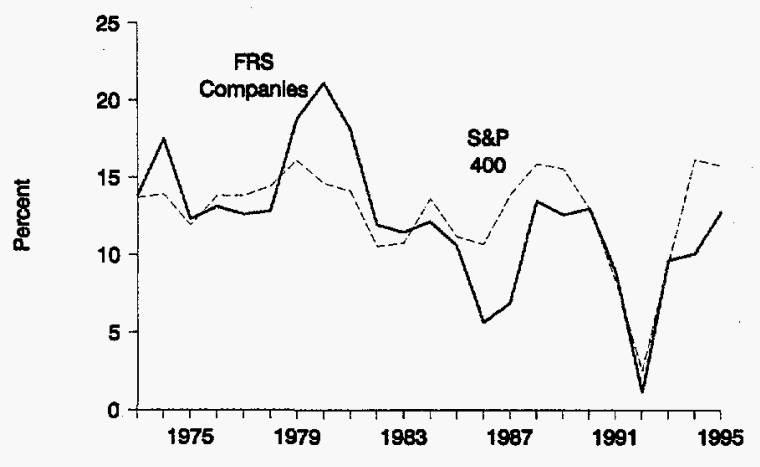

Sources: FRS Companies: Energy Information Administration, Form EIA-28. S\&P 400: Standard \& Poor's Compustat Service.

only 10 FRS companies reported asset commitments in other nonenergy businesses.

Growth in other nonenergy earnings in 1995 reflected the performance of the companies with the largest remaining commitments. USX reported that the income of its US Steel group grew by over 50 percent, reflecting an improvement in the demand for steel. Union Pacific reported a gain of over $\$ 200$ million in operating income from their railroad operations, although this gain was partly offset by loses in trucking operations. Union Pacific reported that car loadings were up 12 percent, in part due to the acquisition of the Chicago and Northwestern
Railroad in 1995, while average prices improved. Exxon's other nonenergy operations consist of electric power production (nearly all in Hong Kong) and copper production in Chile. Exxon reported a sizable gain in their other nonenergy income due to increased power sales, higher copper prices, and overall improved cost control. ${ }^{9}$

Among the energy lines of business, the performance of the FRS companies' foreign oil and gas production stood out. Net income from these operations (excluding unusual items) rose by $\$ 1.7$ billion, or 38 percent, above the level of 1994 (Table 2). In contrast, domestic upstream (upstream includes oil and gas exploration, development, and production) income was nearly flat between 1994 and 1995.

At $\$ 6.1$ billion, foreign upstream income exceeded income from domestic upstream operations, the sixth time in the 10 years since the 1986 oil price crash that this has occurred. Accordingly, most of the growth in the FRS companies' exploration and development spending after 1986 has gone to foreign locales. In 1995, the performance of foreign upstream compared with the performance of domestic upstream reflected not only this segment's growing share of capital resources but also oil and gas market developments in 1995.

Both domestic and foreign upstream operations benefitted from an increase in crude oil prices of about $\$ 1.50$ per barrel. However, the FRS companies' foreign oil production was up one percent, while domestic oil production declined one percent. Natural gas prices were down sharply in the United States and Canada as 1995's heating

'USX Corporation, Securities and Exchange Commission Form 10-K, p. S-24; Union Pacific Corporation, 1995 Annual Report , pp. 23, 33; and Exxon Corporation, 1995 Annual Report, pp. 21, F2. 
Table 2. Contributions to Net Income by Line of Business for FRS Companies, 1994-1995 (Million Dollars)

\begin{tabular}{|c|c|c|c|c|c|c|}
\hline \multirow[b]{2}{*}{ Line of Business } & \multicolumn{3}{|c|}{ Net Income } & \multicolumn{3}{|c|}{ Net Income Excluding Unusual Items } \\
\hline & 1994 & 1995 & $\begin{array}{c}\text { Percent Change } \\
1994-1995 \\
\end{array}$ & 1994 & 1995 & $\begin{array}{c}\text { Percent Change } \\
1994-1995 \\
\end{array}$ \\
\hline \multicolumn{7}{|l|}{$\begin{array}{l}\text { Petroleum } \\
\text { U.S. Petroleum }\end{array}$} \\
\hline Production ... & 4,780 & 3,698 & -22.6 & 5,761 & 5,706 & -1.0 \\
\hline Refining/Marketing $\ldots \ldots \ldots \ldots$ & 1,845 & 508 & -72.5 & 2,290 & 1,220 & -46.7 \\
\hline Pipelines...$\ldots \ldots$. & 1,833 & 2,167 & 18.2 & 1,747 & 2,206 & 26.3 \\
\hline Total U.S. Petroleum . . . . . . . . & 8,458 & 6,373 & -24.7 & 9,798 & 9,132 & -6.8 \\
\hline \multicolumn{7}{|l|}{ Foreign Petroleum } \\
\hline Production & 3,975 & 5,942 & 49.5 & 4,461 & 6,134 & 37.5 \\
\hline Refining/Marketing $\ldots \ldots \ldots \ldots \ldots$ & 1,997 & 2,409 & 20.6 & 2,743 & 2,673 & -2.6 \\
\hline International Marine $\ldots \ldots \ldots \ldots \ldots$ & -33 & -38 & -- & -33 & -13 & -- \\
\hline Total Foreign Petroleum $\ldots \ldots \ldots$ & 5,939 & 8,313 & 40.0 & 7,173 & 8,794 & 22.6 \\
\hline Total Petroleum ... & 14,397 & 14,686 & 2.0 & 16,969 & 17,926 & 5.6 \\
\hline Coal & 163 & 311 & 90.8 & 289 & 495 & 71.3 \\
\hline Other Energy $\ldots \ldots \ldots \ldots \ldots \ldots \ldots$ & 151 & 173 & 14.6 & 157 & 214 & 36.3 \\
\hline Nonenergy ................... & 6,171 & 12,642 & 104.9 & 7,156 & 12,589 & 75.9 \\
\hline Total Allocated ... & 20,882 & 27,812 & 33.2 & 24,571 & 31,224 & 27.1 \\
\hline Nontraceables and Eliminations ..... & $-4,335$ & $-6,681$ & -- & $-5,238$ & $-6,205$ & -- \\
\hline Consolidated Net Income $\theta^{a} \ldots \ldots \ldots$ & 16,547 & 21,131 & 27.7 & 19,333 & 25,019 & 29.4 \\
\hline
\end{tabular}

${ }^{2}$ The total amount of unusual items was $-\$ 2,786$ million and $-\$ 3,888$ million in 1994 and 1995 , respectively.

$--=$ Not meaningful.

Note: In petroleum, the sum of components may not equal total due to nontraceables and eliminations.

Source: Energy Information Administration, Form ElA-28.

season ended with a large overhang of natural gas stocks and heating oil inventories. Outside North America, natural gas prices received by FRS companies were up slightly. While the companies were able to step up natural gas production outside North America in 1995 by four percent over 1994 production, in the United States, their natural gas production was less than one percent above their prior-year level.

Cost-cutting was evident in upstream operations in 1995. The FRS companies were able to reduce out-of-pocket expenses in both U.S. and foreign upstream operations. Extraction costs, exploratory expenses, and overhead were all down in 1995.

U.S. refining and marketing operations were adversely affected by market developments in 1995. The FRS companies' U.S. operations registered a \$1.1-billion tumble in net income, a 47-percent decline. A concentration of adverse developments in the first quarter of 1995 ac- counted for most of the poor financial performance of U.S. refining. The United States began the year with high levels of natural gas in storage and relatively large inventories of distillate. Had the remainder of the heating season been as frigid as the prior year, the high level of heating fuel stocks would have proven profitable. However, winter weather in the first quarter of 1995 was relatively mild: heating-degree days were 13 percent less than in the first quarter of 1994. As a result, drawdowns of distillate stocks proceeded at a sluggish pace, a result which led to deviations from the typical pattern of gasoline production and stocking prior to the secondquarter onset of the driving season.

Also, the first quarter of 1995 held additional adversities for East Coast refiners. A number of governmental jurisdictions, mainly in the Northeast, that had been expected to receive shipments of reformulated gasoline (RFG) due to their voluntary acceptance of environmentally safer fuel standards (the so-called, "opt-ins") were allowed to 
reverse their earlier decisions, leaving refiners with unintended buildups of RFG, a product which also costs more to produce than conventional gasoline.

Taken together, these first-quarter developments resulted in the tightest squeeze on the margin between prices received by refiners and raw material input prices paid by them in six years. The remainder of the year was more in keeping with normal patterns of refined product demand and, aided by a relatively chilly start to the 1995-1996 heating season, refiners' 'margins over the last nine months of 1995 were close to those for the last nine months of 1994. Although FRS refiners continued to cut in the last nine months was sufficient to offset the adversities of the first quarter.

Bottom-line results of foreign refining and marketing operations, in contrast to domestic results, were basically flat between 1994 and 1995. Refining margins abroad worsened in 1995, particularly in Europe. Increased foreign refinery output and utilization rates, lower income tax rates, and increased earnings of unconsolidated affiliates offset the effects of lower margins. Unconsolidated affiliates are entities in which the reporting company has up to a 50-percent ownership interest. The results of unconsolidated affiliates' operations are reported as the proportionate share of earnings accruing to the parent company, rather than being included in the components of the parent company's income statement.

The bulk of the FRS companies' unconsolidated affiliates' earnings in foreign refining and marketing reflect activity in the rapidly growing locales of the Pacific Rim and Southeast Asia. Of the 1.4 million barrels per day of unconsolidated affiliates' refinery capacity proportionately owned by the FRS companies, 71 percent is located in the rapidly growing economies of Southeast Asia and the Pacific Rim. In contrast, 26 percent of the foreign refinery capacity reflected in the FRS companies' consolidated operations was located in the Asia/Pacific region, but 69 percent was located in Europe and the Western Hemisphere. The difference in results was striking: net income

\section{Figure 4. Revenues and Operating Expenses for the Chemical Segment for FRS Companies, 1981-1995}

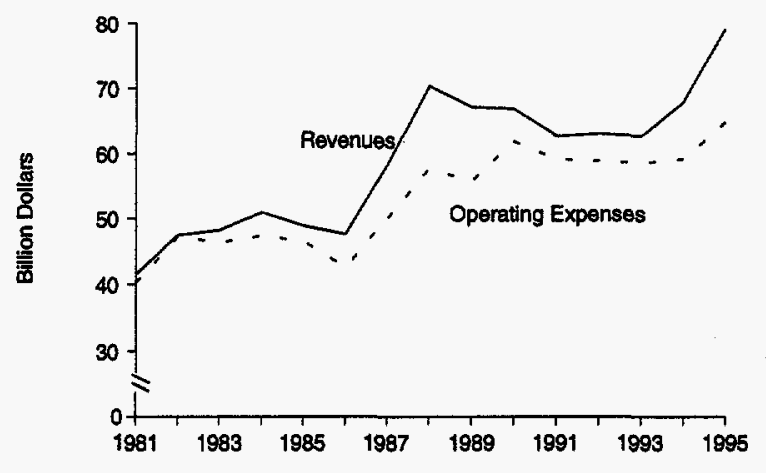

Sources: 1981-1986: Energy Information Administration, Form ElA-28, 1987-1995: Company annual reports to shareholders.

from consolidated foreign refining operations declined $\$ 200$ million between 1994 and 1995, but foreign refining income from unconsolidated affiliates increased $\$ 150$ million, largely reflecting the differential levels of demand in the geographic locales involved.

Transportation rounds out this overview of income from petroleum and natural gas operations. The FRS companies' pipeline revenues are split about 55 percent to 45 percent between natural gas pipelines and liquids pipelines, respectively. Revenues were down for both segments. As natural gas pipelines continue to make the transition to being common carriers, revenues other than transport revenues (mainly natural gas sales) are dwindling. Liquids pipeline operations, overall, face a mature, declining crude oil resource base in the United States. The long-term decline has a depressing effect on throughput volumes. Nevertheless, both pipeline segments registered higher income, with a combined rise of 26 percent between 1994 and 1995. Operating cost reductions were the key to improved income in the FRS companies' pipelines in 1995.

Table 3. Operating Income in Chemicals and Other Nonenergy Segments for FRS Companies, 1994-1995 (Million Dollars)

\begin{tabular}{|c|c|c|c|}
\hline Segment & 1994 & 1995 & $\begin{array}{c}\text { Percent Change } \\
1994-1995\end{array}$ \\
\hline 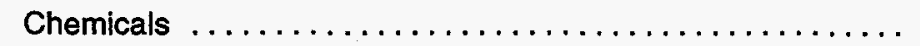 & 8,609 & 14,254 & 65.5 \\
\hline Other Nonenergy $\ldots \ldots \ldots \ldots \ldots \ldots \ldots \ldots \ldots \ldots$ & 914 & 2,066 & 126.0 \\
\hline
\end{tabular}

Sources: Energy information Administration, Form EIA-28, except for chemicals segment operating income, which was compiled from company annual reports to shareholders. 

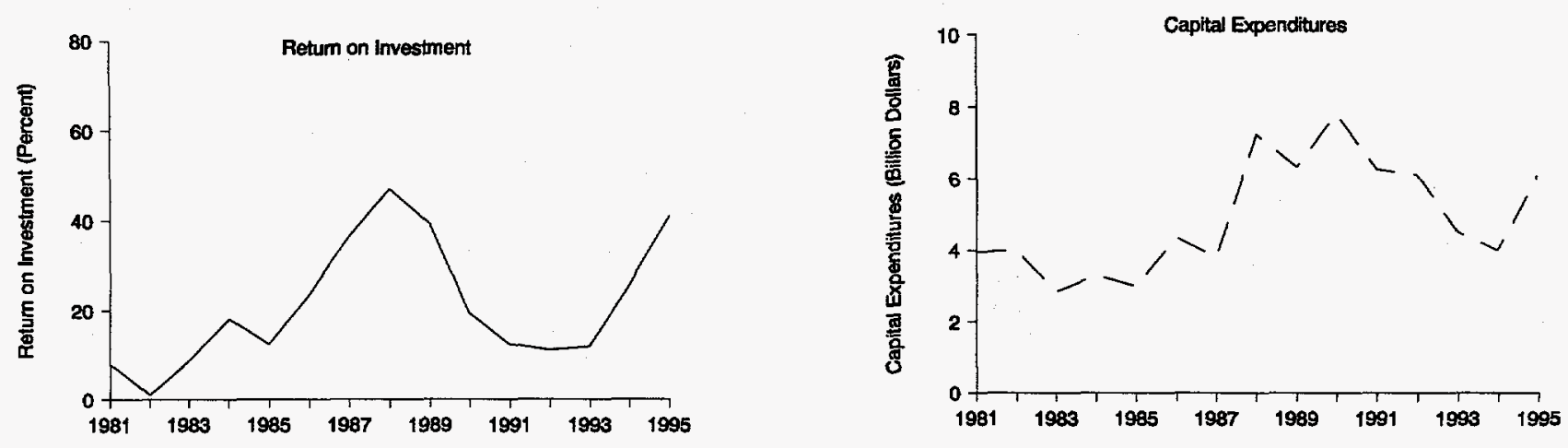

Note: Return on investment is operating income as a percent of net property, plant, and equipment.

Source: Energy information Administration, Form EIA-28 and company annual reports to shareholders.

The other source of energy income for FRS companies, which consists of coal operations and other energy activities, accounted for only 1 percent of total line-ofbusiness revenues but added $\$ 709$ million to overall net income in 1995, a 59-percent increase over 1994's results. Both lines of business posted large gains. Interpretation of results for the FRS companies' coal operations is obscured by recent restructurings. Shell Oil severed their last connection to the U.S. coal industry when they sold their 25-percent equity interest in Zeigler Coal in 1994. Sun decided to report their remaining coal activities as part of their continuing operations in 1995 after carrying their unsold coal properties as a discontinued operation. Ashland reported Ashland Coal as a consolidated operation, subsequent to gaining a majority stake in this subsidiary in 1995, rather than as an investment. Excluding these three companies, net income from coal operations (excluding unusual items) was up 9 percent. This relatively flat performance reflected the overall stable coal prices realized by the FRS companies between 1994 and 1995.

The other energy line of business encompasses a variety of energy sources beyond petroleum, natural gas, and coal. Until the 1990's, these activities yielded, overall, operating losses for the FRS companies in every year. In the 1990's, though, the other energy line of business has produced positive net income which quadrupled from 1990 to 1995. Electric generation and cogeneration, Canadian tar sands production, and geothermal energy accounted for nearly all of the FRS companies' revenue and income in other energy during this period. Enron, the largest player among the FRS companies in electric power, reported improved income from these operations in 1995 compared with income in 1994 due to growth in electricity demand and production. Coastal reported a boost in earnings as their new power plant in El Salvador came on line. In Canadian tar sands production, Exxon reported record production which, combined with higher oil prices, yielded a gain in other energy income. Unocal reported that earnings from geothermal energy held fairly steady despite the adverse effects of a typhoon in the Phillippines and a falloff in utility purchases of geothermally generated power.

\section{Downsizing Moderates hut Downstream Restructuring Continues}

Downsizing is both a method for, and consequence of, reducing a corporation's scope of operations and consolidating resources in the remaining businesses. Downsizing, measured in terms of employee reduction, by the FRS companies has been relentless in the 1990's but actually began with the decline in oil prices and stockholder dissatisfaction in the early 1980's (Figure 6). In 1995, the pace of downsizing appeared to ease. The FRS companies reduced their employment by 4 percent between 1994 and 1995, down from the 7 percent annual reduction of the prior 5 years. Downsizing and the application of advancing technologies have produced cost reductions and improved profitability. ${ }^{10}$ As reported in subsequent chapters, the FRS companies continued to

\footnotetext{
${ }^{10}$ An analysis of the relationships between downsizing, cost reduction, profitability, and market value appeared in Energy Information Administration, Performance Profiles of Major Energy Producers 1994, DOE/EIA-0206(94)(Washington, DC, February 1996), pp. 8-9.
} 
Figure 6. Number of Employees of FRS Companies, 1981-1995

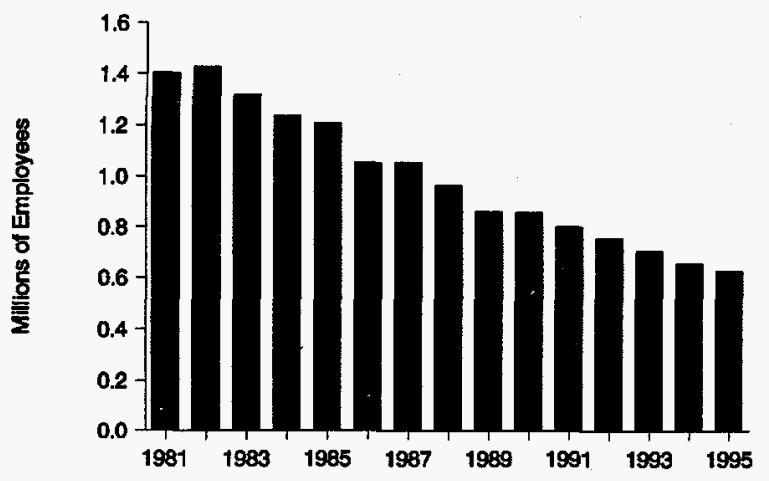

Source: Company annual reports to shareholders.

realize lower unit costs in petroleum and natural gas extraction, transport, processing, and distribution in 1995.

Although downsizing and cost-cutting were evident in 1995, a number of growth areas were evident as well:

- Natural gas reselling and marketing in the United States

- Oil and gas exploration and production in the Gulf of Mexico and a variety of recent frontier locales in Asia and Africa

- Electric power generation in privatizing economies

- Exploration and production in Venezuela through agreements with Petroleos de Venezuela (PDVSA), the state energy company of Venezuela.
This last item is anticipated from the vantage point of 1995 on the basis of public disclosures of agreements reached or likely to be reached. At least 12 FRS companies (incliding the foreign parent companies of BP America and Shell Oil) have been active in targeting Venezuela for future oil investments through agreements with PDVSA and its subsidiaries. To enable readers to better understand this development and the likely partner of a number of FRS companies in future ventures in Venezuela, relevant aspects of PDVSA are reviewed in several of the chapters of this report (see the box entitled, "PDVSA: A Growth-Oriented Multinational," for a general corporate overview).

In 1995, U.S. refining and marketing stood out as the area most subjected to restructuring and consolidation by FRS companies. Kerr-McGee sold their U.S. refining and marketing assets, including three refineries. Chevron sold their Port Arthur, Texas, refinery to Clark Oil and Refining. In the 1990's, the profitability of U.S. refining and marketing has been below that of the FRS companies' overall petroleum line of business (Table 5). The low profitability has made U.S. refining unattractive to investors and, within the context of the FRS companies' capital budgeting decisions, a lesser competitor for cash flow allocations.

The dismal return on domestic refining investment reflects, in part, nearly flat growth in U.S. refined product demand during the 1990's (0.6-percent annual rate for the FRS companies between 1990 and 1995) and, in part, additional capital requirements needed to meet environmental quality standards pursuant to the objectives of the Clean Air Act Amendments of 1990. Although the added capital expenditures appeared to have peaked, the asset base upon which a competitive return must eventually be made has grown greatly.

Table 4. Selected Financial Data for Petroleos de Venezuela and Other Large Multinational Petroleum Companies, 1994 (Percent)

\begin{tabular}{|c|c|c|c|c|}
\hline Financial Data & PDVSA & & U.S. Multinationals & $\begin{array}{c}\text { Non- U.S. } \\
\text { Multinationals }\end{array}$ \\
\hline Percent Change in Net Fixed Assets, 1989-1994 & 60.1 & & 2.4 & 13.9 \\
\hline Capital Expenditures/Cash Flow, 1994 & 105.7 & 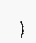 & 68.7 & 75.0 \\
\hline Net Income/Stockholders' Equity, 1994 & 8.0 & & 12.7 & 9.0 \\
\hline Cash Flow/Net Assets, $1994 \ldots \ldots$. . & 12.3 & & 17.3 & 19.2 \\
\hline Effective Tax Rate, $1994 \ldots$ & 59.6 & & 36.2 & 37.1 \\
\hline Dividends/Cash Flow, 1994 & 0.0 & & 31.4 & 21.2 \\
\hline
\end{tabular}

Note: U.S. Multinationals: Amoco, ARCO, Chevron, DuPont, Exxon, Mobil, Phillips Petroleum, Texaco, and USX.

Non-U.S. Multinationals: British Petroleum, Broken Hill Proprietary, Elf Aquitaine, Repsol, Royal Dutch/Shell Group, and Total. Sources: Petroleos de Venezuela S.A., Annual Report 1994; and Compustat Industrial File. 


\section{PDVSA: A Growth-Oriented Multinational}

Although Petroleos de Venezuela (PDVSA) is a state energy company, PDVSA's presence in the capital markets has grown in recent years. Long-term debt of PDVSA increased from $\$ 1.0$ billion in 1990 to $\$ 5.0$ billion in 1994 . Of this latter amount, nearly 60 percent was raised outside of Venezuela including $\$ 1.0$ billion raised in the United States. If full privatization is undertaken, PDVSA will become even more of a major competitor in world capital markets. It is useful, then, to compare PDVSA with two peer groups of corporations in order to assess PDVSA's financial performance relative to other petroleum companies. This comparison is greatly facilitated by PDVSA's recent presentation of their financial statements (in their 1994 Annual Report) on virtually the same basis as publicly-traded U.S. corporations and foreign companies trading on U.S. stock exchanges.

Since PDVSA is large ( $\$ 22$ billion in 1994 revenues), multinational (59 percent of revenues came from sales outside Venezuela), and primarily in petroleum operations (97 percent of revenues are derived from petroleum (including natural gas)), the comparison groups of companies also should have these characteristics. Multinational petroleum companies trading on the New York Stock Exchange with more than $\$ 10$ billion in revenues were therefore chosen to form the comparison group. The first group consists of 10 U.S.-based multinationals (Amoco, ARCO, Chevron, DuPont, Exxon, Mobil, Phillips Petroleum, Texaco, and USX). The second group consists of 6 companies based outside the United States (British Petroleum (UK), Broken Hill Proprietary (Australia), Elf Aquitaine (France), Repsol (Spain), Royal Dutch/Shell Group (Netherlands/UK), and TOTAL (France)).

In comparison to other large U.S. and non-U.S. multinational petroleum companies, PDVSA has pursued a policy of corporate growth in recent years. Over the five years from 1989 to 1994, PDVSA's net fixed assets increased 60 percent while the net fixed assets of the U.S. multinationals and non-U.S. multinationals comparison groups increased 2 percent and 14 percent, respectively (Table 4). In 1994, PDVSA's capital expenditures exceeded their internal cash flow. In contrast, other large petroleum multinationals reinvested only about 71 percent of cash flow in capital assets. It should be noted that while PDVSA's crude oil exploration and production operations (see the box in Chapter 3 entitled "Upstream in Venezuela") are relatively low-cost, Venezuela's OPEC membership--with its associated production quotas--has been a constraint on the expansion of these operations. Consequently, PDVSA has sought outlets for corporate growth as well as for placement of their crude oil production in downstream facilities in industrialized countries, mainly the United States. Further, as their asset base in industrialized countries has grown, their capacity to borrow abroad has increased, further facilitating corporate growth. However, growth may have been achieved at some sacrifice in profitability.

For example, a common measure of corporate profitability is return on equity (net income as a percent of stockholders' equity). As shown in Table 4, PDVSA's return on equity in 1994 was below that of both the U.S. and non-U.S. petroleum multinationals. The relatively low value of return on equity might, in part, be due to some compromises in measuring the equity value of a state energy company. Another measure of performance less affected by measurement issues is cash flow per dollar of net productive assets on the balance sheet. Even by this measure, PDVSA is clearly below other multinational petroleum companies, on average. A possible contributing factor to the apparently low level of PDVSA's profitability may be, in part, an enormously large tax bite. The effective income tax rate (income taxes as a percent of pretax income) for PDVSA in 1994 was 60 percent, well above the effective tax rates of 36 percent for the U.S. group and 37 percent for the non-U.S. group. When the sizable production taxes levied by Venezuela are taken into account, the total fiscal take on PDVSA equalled 71 percent in 1994.

As a state-owned energy company, PDVSA does not pay dividends. However, the comparison companies in total paid out $\$ 17$ billion in cash dividends to shareholders in 1994, about 27 percent of their cash flow. If the taxes paid to Venezuela are viewed as both a payment to the fiscal authority and a return on investment to the owners of the assets, then PDVSA's apparently very high tax burden may be an artifact of state ownership. Since income taxes and dividends for the comparison group were 75 percent of pretax income, and the statutory income tax rate for PDVSA is 67.7 percent, this appears to be the case. Nevertheless, the statutory income tax rate for PDVSA is still high in comparison with the general corporate tax rate of 34 percent in Venezuela. 
Table 5. Return on Investment by Line of Business for FRS Companies, 1986-1995 (Percent)

\begin{tabular}{|c|c|c|c|c|c|c|c|c|c|c|}
\hline Line of Business & 1986 & 1987 & 1988 & 1989 & 1990 & 1991 & 1992 & 1993 & 1994 & 1995 \\
\hline Petroleum. & 5.5 & 6.2 & 7.3 & 6.7 & 9.5 & 7.0 & 5.6 & 6.4 & 5.6 & 5.7 \\
\hline U.S. Petroleum & 3.0 & 4.9 & 6.3 & 5.8 & 7.9 & 4.9 & 4.4 & 4.9 & 5.2 & 4.0 \\
\hline Oil and Gas Production ........ & 0.8 & 4.1 & 2.8 & 2.9 & 8.5 & 5.1 & 5.9 & 5.3 & 5.5 & 4.4 \\
\hline Refining/Marketing $\ldots \ldots \ldots \ldots \ldots$ & 4.5 & 2.9 & 14.7 & 11.5 & 5.1 & 2.0 & -0.4 & 3.4 & 3.6 & 1.0 \\
\hline Pipelines $\ldots \ldots \ldots \ldots \ldots \ldots \ldots$ & 13.2 & 12.8 & 9.6 & 10.2 & 11.2 & 10.7 & 8.4 & 6.4 & 7.6 & 9.1 \\
\hline Foreign Petroleum & 12.8 & 9.5 & 9.9 & 8.7 & 12.5 & 11.0 & 7.9 & 9.2 & 6.2 & 8.4 \\
\hline Oll and Gas Production ............. & 11.6 & 12.4 & 9.2 & 8.9 & 13.1 & 9.1 & 8.2 & 8.6 & 6.5 & 9.3 \\
\hline Refining/Marketing $\ldots \ldots \ldots \ldots \ldots$ & 16.3 & 4.7 & 11.6 & 8.0 & 11.2 & 14.6 & 7.8 & 10.6 & 6.1 & 7.2 \\
\hline International Marine .............. & 5.3 & -3.6 & 6.8 & 12.4 & 11.7 & 15.6 & -1.2 & 1.2 & -2.0 & -2.5 \\
\hline Coal .... & 2.7 & 5.1 & 6.7 & 5.0 & 3.3 & 8.7 & -9.3 & 7.6 & 4.0 & 6.9 \\
\hline Other Energy ..... & .0 .8 & 0.5 & -2.5 & -2.3 & 2.6 & 2.8 & 1.8 & 4.1 & 4.8 & 6.1 \\
\hline Nonenergy $\ldots \ldots \ldots \ldots \ldots \ldots \ldots$ & 5.1 & 12.2 & 20.3 & 17.3 & 7.8 & -2.9 & 2.1 & 4.7 & 10.5 & 19.4 \\
\hline
\end{tabular}

Note: Return on investment measured as contribution to net income/net investment in place.

Source: Energy Information Administration, Form ElA-28.

Absent future growth in demand for the products of U.S. refiners, further consolidation is likely before competitive rates of return are realized.

Another focus of the FRS companies' downsizing has been outlays for research and development (R\&D). The share of cash flow allocated to R\&D has fallen sharply in recent years (Figure 7) as have expenditures for all categories of R\&D activity (Figure 8 ).

\section{Cash: Sources and Uses}

\section{Debt Reduced as Internal Cash Flow Reaches a 10-Year High}

The FRS companies' cash flow from operations reached $\$ 58.5$ billion in 1995 , up $\$ 10.2$ billion from the prior year (Table 6), the highest level since at least $1986 .{ }^{11}$ All lines of business, except downstream petroleum operations (refining, cash flow, marketing, and transport), added more to cash flow in 1995 than in 1994. The largest increase was $\$ 6.5$ billion from chemical operations.
Issuance of long-term debt ranked second to internal cash flow as a source of funds (Table 7). Proceeds from long-term debt, at $\$ 19.9$ billion in 1995 , could be viewed as a rebound from the low level of debt issuance in 1994 to a level typical of the rest of the 1990's. However, the increased borrowing was almost entirely due to unusually large transactions by DuPont and Union Pacific in 1995. In April 1995, DuPont repurchased 156 million shares of its common stock from Seagram for $\$ 8.8$ billion. Seagram gained a 23-percent share of DuPont in a series of takeover battles for Conoco in 1981, culminating in DuPont's acquisition of Conoco. DuPont's stock buyback was one of the largest redemptions in history. DuPont borrowed $\$ 8.3$ billion but subsequently sold new shares of common stock for $\$ 1.7$ billion, which, together with internal cash flow, was used to reduce debt. Union Pacific made two railroad-related acquisitions (described in the next section) for $\$ 2.2$ billion in cash. This company reported issuance of $\$ 2.3$ billion in debt to finance the transactions and, like DuPont, registered a large outlay for debt reduction. Excluding these two companies, proceeds from long-term debt issuance by the remaining 22 FRS companies dropped by

\footnotetext{
${ }^{11}$ Cash is defined as currency, demand deposits, and interest-bearing assets of less than $\mathbf{3 0}$ days maturity. Generally, cash flow from operations is computed by adding to (subtracting from) net income those cost (revenue) items that did not actually involve an outlay (receipt) of cash. The largest of these non-cash items is the cost of depreciation, depletion, and amortization. Also, outlays (receipts) of cash that were recognized as non-cash items in previous income statements (e.g., provisions for a legal settlement taken as a charge against income in a previous year but not actually paid until the current year) are subtracted from (added to) net income in computing cash flow. Lastly, changes in working capital (excluding cash) due to operations are subtracted.
} 
Figure 7. Research and Development Expenditures as a Percent of Cash Flow from Operations for FRS Companies, 1982-1995

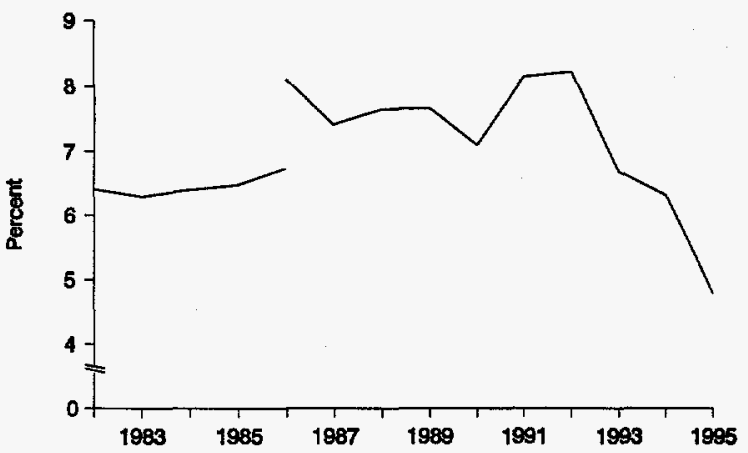

Note: Cash flow was reported on a working capital basis prior to 1987 and was reported on a cash and cash-equivalent basis thereafter.

Source: Energy Information Administration, Form EIA-28.
Figure 8. Research and Development Expenditures by Line of Business for FRS Companies, 1982-1995

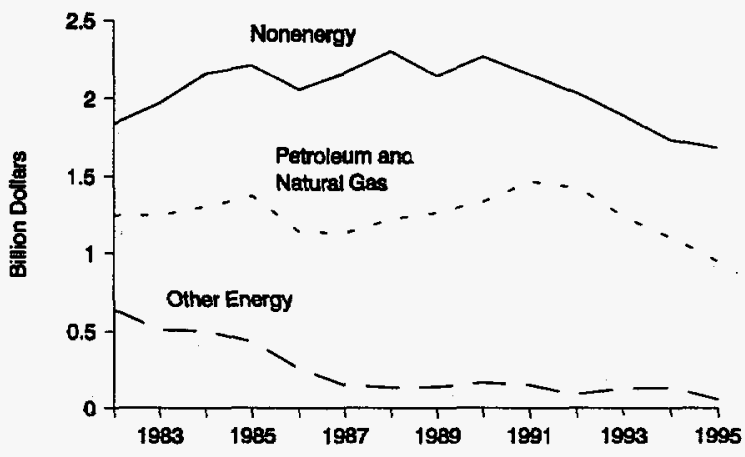

Source: Energy Information Administration, Form ElA-28.

Table 6. Line-of-Business Contributions to Pretax Cash Flow for FRS Companies, 1994-1995 (Billion Dollars)

\begin{tabular}{|c|c|c|c|}
\hline Contribution to Pretax Cash Flow ${ }^{a}$ & 1994 & 1995 & $\begin{array}{c}\text { Percent Change } \\
\text { 1994-1995 }\end{array}$ \\
\hline \multicolumn{4}{|l|}{ Petroleum } \\
\hline Oil and Gas Production . & 35.1 & 38.1 & 8.5 \\
\hline Refining, Marketing, and Transport $\ldots \ldots \ldots \ldots \ldots$ & 15.0 & 13.9 & -7.7 \\
\hline Coal and Other Energy $\ldots \ldots \ldots \ldots \ldots \ldots \ldots \ldots \ldots$ & 0.8 & 1.2 & 35.1 \\
\hline 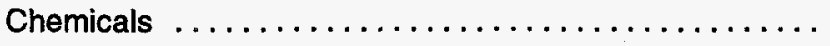 & 11.2 & 17.7 & 58.2 \\
\hline Other Nonenergy $\ldots \ldots \ldots \ldots \ldots \ldots \ldots \ldots \ldots \ldots \ldots$ & 2.0 & 2.8 & 43.4 \\
\hline Nontraceable $\ldots \ldots \ldots \ldots \ldots \ldots \ldots \ldots \ldots \ldots$ & -1.6 & -3.0 & - \\
\hline Total Contribution to Pretax Cash Flow ${ }^{\mathrm{a}} \ldots$ & 62.6 & 70.7 & 13.1 \\
\hline 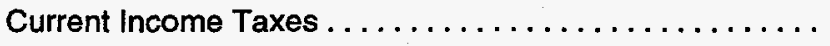 & -10.0 & -13.1 & 31.6 \\
\hline Other (Net) . . . . . . . . . . . . . & -4.3 & 0.8 & - \\
\hline Cash Flow from Operations $\ldots \ldots \ldots \ldots \ldots \ldots \ldots$ & 48.3 & 58.5 & 21.1 \\
\hline
\end{tabular}

aDefined as the sum of operating income, depreciation, depletion, and amortization, and dry hole expense.

- = Not meaningful.

Note: Sum of components may not equal total due to independent rounding. Percent changes were calculated from unrounded data.

Source: Energy Information Administration, Form EIA-28.

\$2.1 billion, from 1994 to 1995 , while repayments of long-term debt remained flat.

On balance, the FRS companies reduced long-term debt in their balance sheets to levels not seen since the early 1980 's. At the end of 1995, the FRS companies' long-term debt was at its lowest value since 1983 . Similarly, the ratio of long-term debt to stockholders' equity, a measure of the role of debt in the balance sheet, sank to 51 percent-the lowest level in over a decade and well below the peak value of 59 percent in 1992. In contrast, the debt-equity ratio for other large U.S. industrial corporations, as represented by the S\&P 400 , rose to 68 percent in 1995 (Table B16 in Appendix B).

Although U.S. refining and marketing was the focus of the most intense restructuring efforts in 1995, less than $\$ 1$ billion was realized by FRS companies from the sale of downstream assets. The \$2.7-billion uptick in cash from asset sales (Table 7) was traceable in part to sales of chemical facilities. Mobil sold its plastics division and a phosphate operation for a total of $\$ 1.6$ billion and 
Occidental Petroleum sold chemical manufacturing facilities for $\$ 0.8$ billion, including its agricultural chemicals division, high-density polyethylene business, and polyvinyl chloride facilities. The chemical asset sales represented a realignment of investment targets rather than a retrenchment in chemicals: both Mobil and Occidental reported increased capital expenditures for chemical operations in 1995 compared with 1994 expenditures. In their 1995 Annual Report, Mobil stated, "We've learned that the best chemical companies don't try to 'do it all' Rather, companies with just a handful of leading businesses often outperform more highly diversified companies with an abundance of product lines competing in a wide variety of unrelated markets."

Upstream asset sales included Oryx Energy's sale of their North Sea assets for \$390 million and Texaco's sale of various U.S. oil and gas properties, mainly to Apache Petroleum, for $\$ 624$ million. Also, Enron sold 19 percent of the stock of its upstream subsidiary, Enron Oil and Gas, for $\$ 650$ million and Union Pacific sold 17 percent of Union Pacific Resources to the public for \$844 pursuant to a spinoff of this subsidiary to Union Pacific shareholders planned for 1996.
Despite the divestitures of U.S. upstream assets, U.S. oil and gas production surpassed foreign oil and gas production as the FRS companies' primary target of investment for the second consecutive year (Table 8). However, the FRS companies' capital expenditures exhibited an unusual pattern in 1995: nearly all of the growth was from the nonenergy line of business.

\section{Targets of Investment}

\section{Railroad Mergers, Chemical Projects Lead to Near-Record Outlays for Nonenergy Businesses}

The FRS companies' total capital expenditures ${ }^{12}$ were $\$ 47.7$ billion in 1995 , up $\$ 8.6$ billion, or 22 percent, from the previous year's expenditures (Table 8). The \$7.1billion rise in capital expenditures for nonenergy businesses accounted for most of the increase. At \$13.4 billion, the FRS companies' capital expenditures for nonenergy businesses were second only to 1982 's outlays of $\$ 14.6$ billion when DuPont and USX joined the ranks

Table 7. Sources and Uses of Cash for FRS Companies, 1994-1995 (Billion Dollars)

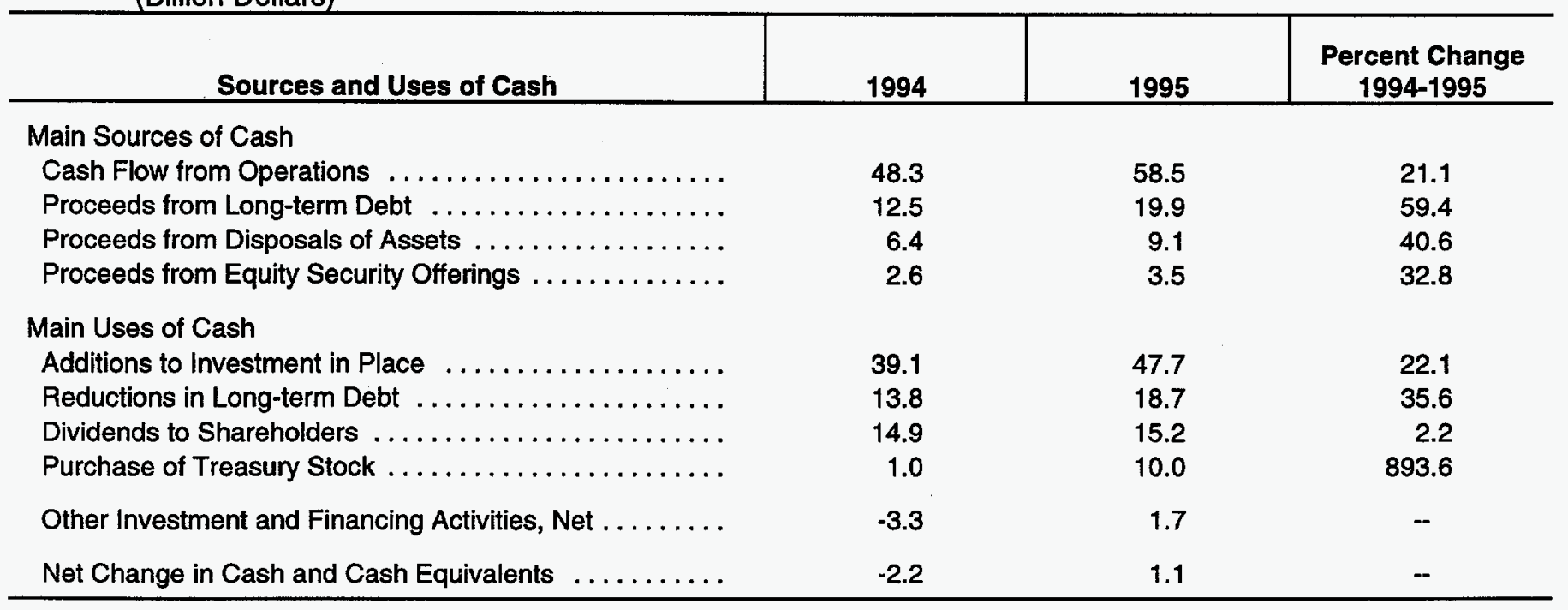

-- = Not meaningful.

Note: Sources minus Uses plus Other Investment and Financing Activities (Net) may not equal Net Change in Cash and Cash Equivalents due to independent rounding. Percent changes were calculated from unrounded data.

Source: Energy Information Administration, Form EIA-28.

\footnotetext{
${ }^{12}$ To the extent possible, capital outlays are measured by additions to investment in place, which are defined as additions to property, plant, and equipment (PP\&E) plus additions to investment and advances. In 1995, additions to PP\&E accounted for 93 percent of capital outlays so measured. However, because additions to investments and advances were not collected for some FRS segments prior to 1981, capital outlays are sometimes measured solely by additions to PP\&E.
} 
of FRS companies through mergers with Conoco and Marathon, respectively. However, the spike in nonenergy capital expenditures does not represent an effort by the FRS companies to diversify the scope of their enterprises but, instead, can be traced primarily to Union Pacific's railroad acquisitions and also to a surge in capital outlays for chemical operations.

Union Pacific acquired the Chicago and Northwestern Railroad and 25-percent ownership of Southern Pacific in 1995. The latter acquisition was the first step in a planned total takeover of Southern Pacific, pending official government approvals. Although the cash outlays for these two acquisitions totaled $\$ 2.2$ billion (Table 9), the total impact on additions to investment in place (the measure of capital expenditures used in this report) was $\$ 4.6$ billion due to the workings of merger purchase accounting. ${ }^{1}$ These transactions effectively mark Union Pacific's exit from the energy industry after 1995. Union Pacific, in 1995, realized $\$ 844$ million in cash from the sale of stock in Union Pacific Resources, pursuant to a spinoff of Union Pacific Resources to Union Pacific shareholders planned for 1996. Following the stock sale, Union Pacific Resources declared a dividend of $\$ 1.6$ billion payable to Union Pacific. ${ }^{2}$ As a consequence, Union Pacific's energy operations disgorged over $\$ 2$ billion in cash which became available to pay off debt incurred from the railroad acquisitions.

Chemical operations provided targets of investment for the 16 FRS companies active in various lines of chemical businesses. Overall capital expenditures for chemicals were up 52 percent (Table 8), with all but two companies reporting an increase in expenditures. Sizable increases were reported by Amoco, DuPont, and Exxon, largely for chemical plant capacity expansions. The sharp upswing was in line with past investment patterns whereby favorable profit developments were quickly followed by additional capital expenditures which increased productive capacity (Figure 5).

\section{Energy Investment Reflects Surge in Drilling}

Oil and gas production accounted for the rise in capital expenditures for energy operations in 1995. As in 1994, capital expenditures for U.S. oil and gas production outpaced foreign oil and gas production in 1995, \$11.4 billion vs. $\$ 10.7$ billion (Table 8). Upstream spending reflected increased drilling activity in the United States and abroad. The FRS companies' worldwide drilling expenditures (excluding exploratory dry hole expense ${ }^{3}$ ) were up $\$ 2.1$ billion over 1994 expenditures, while completed wells were up 9 percent.

Generally favorable price developments in 1995 encouraged drilling activity. Oil prices in the United States and abroad were up about 10 percent or so over 1994 prices. Accordingly, the FRS companies' worldwide completions of oil wells were up 14 percent. Natural gas prices showed a geographically diverse pattern in 1995. Outside North America, natural gas prices realized by FRS producers increased 5 percent, with gas well completions rising 24 percent. In Canada, natural gas prices tumbled sharply from 1994 levels as did gas well completions. In the United States, the FRS companies' natural gas drilling was up 14 percent despite lower realized wellhead prices, possibly indicating that FRS companies, overall, took a long-term view of natural gas prospects in the United States.

The upswing in the FRS companies' drilling in 1995 also reflected longer term developments. Advancing technologies, including 3-D seismic, horizontal drilling, and deep water drilling, have increased the number and scope of economic drilling prospects. Availability of Federal Outer Continental Shelf (OCS) leases, generally in the Gulf of Mexico, has complemented the trend in technology. For example, the Federal OCS acreage awarded by the Minerals Management Service quadrupled between 1992 and 1995.

\section{Downstream Expenditures Remain High, But Down From Peak Levels}

Capital expenditures for U.S. refining, after reaching a 1990 's peak of $\$ 5.2$ billion in 1992, steadily declined to $\$ 3.6$ billion in 1995. Completion of upgrading projects and environmental quality projects largely underlay the recent decline in capital expenditures. The main thrusts of U.S. refinery investment in the 1990's have been upgrading to produce more light products, particularly gasoline, and compliance with environmental requirements. However, upgrading (as measured by gasoline and distillate as a

\footnotetext{
${ }^{1}$ Union Pacific Corporation, 1995 Annual Report, pp. 35, 36, 42, and 50. Figure 7 and Table 8 show the value of property, plant and equipment, and investments and advances added to the companies' books as a result of acquisitions rather than the value of the transactions. The reported value of an acquisition shown in Table 9 is generally the cash outlay and can differ from the effect on additions to investment in place due to assumptions of liabilities and goodwill assets acquired.

${ }^{2}$ Union Pacific Corporation, 1995 Annual Report, p. 34.

${ }^{3}$ For companies using the "successful efforts" method for oil and gas accounting (22 of 24 FRS companies use "successful efforts" rather than "full cost" accounting), the cost of exploratory wells is charged to income (i.e., expensed) rather than capitalized (i.e., treated as a capital expenditure).
} 
Table 8. Additions to Investment in Place by Line of Business for FRS Companies, 1994-1995 (Billion Dollars)

\begin{tabular}{|c|c|c|c|c|}
\hline Line of Business & 1994 & 1995 & $\begin{array}{c}\text { Percent } \\
\text { Change } \\
\text { 1994-1995 }\end{array}$ & $\begin{array}{c}\text { Percent Change } \\
\text { Excluding Mergers } \\
\text { and Acquisitions } \\
1994-1995\end{array}$ \\
\hline \multicolumn{5}{|l|}{$\begin{array}{l}\text { Petroleum } \\
\text { U.S. Petroleum }\end{array}$} \\
\hline Production..... & 10.9 & 11.4 & 4.5 & 13.4 \\
\hline \multicolumn{5}{|l|}{ Refining/Marketing } \\
\hline Refining $\ldots \ldots \ldots \ldots \ldots$ & 4.2 & 3.6 & -14.0 & -10.5 \\
\hline Marketing $\ldots \ldots \ldots \ldots \ldots \ldots \ldots \ldots \ldots \ldots \ldots \ldots$ & 1.8 & 1.9 & 2.8 & 2.9 \\
\hline Transport...$\ldots \ldots \ldots \ldots \ldots$ & 0.3 & 0.3 & -4.1 & -4.1 \\
\hline Total Refining/Marketing & 6.3 & 5.8 & -8.7 & -6.3 \\
\hline Pipelines $\ldots \ldots \ldots \ldots \ldots$ & 0.8 & 1.0 & 19.9 & 9.2 \\
\hline Total U.S. Petroleum ............ & 18.1 & 18.2 & 0.6 & 5.7 \\
\hline \multicolumn{5}{|l|}{ Foreign Petroleum } \\
\hline Production & 9.8 & 10.7 & 10.0 & 8.2 \\
\hline Refining/Marketing & 3.1 & 3.0 & -4.9 & -4.9 \\
\hline International Marine ..... & 0.3 & 0.3 & 10.0 & 10.0 \\
\hline Total Foreign Petroleum $\ldots \ldots \ldots \ldots \ldots \ldots$ & 13.1 & 14.0 & 6.5 & 4.8 \\
\hline Total Petroleum & 31.2 & 32.2 & 3.0 & 5.3 \\
\hline Coal ... & 0.0 & 0.3 & -- & -- \\
\hline Other Energy .... & 0.3 & 0.4 & 52.0 & 47.2 \\
\hline \multicolumn{5}{|l|}{ Nonenergy } \\
\hline Chemicals & 4.0 & 6.1 & 52.0 & 47.2 \\
\hline Other Nonenergy . & 2.3 & 7.3 & 211.8 & 14.2 \\
\hline Total Nonenergy $\ldots \ldots \ldots \ldots \ldots \ldots \ldots \ldots$ & 6.3 & 13.4 & 111.1 & 35.0 \\
\hline Nontraceables $\ldots \ldots \ldots \ldots \ldots \ldots \ldots \ldots \ldots \ldots \ldots$ & 1.3 & 1.5 & - & - \\
\hline Additions to Investment in Place ${ }^{a}$. & 39.1 & 47.7 & 22.1 & - \\
\hline Additions Due to Mergers and Acquisitions .......... & 3.2 & 7.5 & 137.4 & - \\
\hline Total Additions Excluding Mergers and Acquisitions.... & 35.9 & 40.2 & 11.9 & - \\
\hline Addendum: Environmental Capital Expenditures ..... & 4.3 & 3.5 & -17.5 & -- \\
\hline
\end{tabular}

${ }^{a}$ Measured as additions to property, plant, and equipment, plus additions to investments and advances.

$--=$ Not meaningful.

Note: Sum of components may not equal total due to independent rounding. Percent changes were calculated from unrounded data.

Source: Energy Information Administration, Form EIA-28, except for environmental capital expenditures, which came from company filings of Securities and Exchange Commission Form 10-K.

share of FRS refinery output) appeared to peak and stabilize in the 1993-1995 period at 73 to 74 percent, up from 69 percent in 1989. Growth in motor fuel demand, spurred by the low level of petroleum prices following the oil price collapse in 1986, encouraged investment in lightproduct capability.

In 1990, the Clean Air Act Amendments became law and required U.S. refiners to produce oxygenated gasolines by late 1992, lower sulfur diesel fuels by late 1993, and reformulated gasoline by January 1,1995 . These requirements were in addition to meeting standards related to airborne emissions and effluent discharges into waterways from refineries. The FRS refiners stepped up their expenditures for the necessary facilities. Environmentallyrelated capital expenditures peaked in 1993 at 40 percent of overall capital expenditures for refining, up from 12 
Table 9. Value of Mergers, Acquisitions, and Related Transactions by FRS Companies, 1995 (Million Dollars)

\begin{tabular}{|c|c|c|}
\hline Line of Business and Acquiring Company & Acquisition & $\begin{array}{c}\text { Reported } \\
\text { Value } \\
\text { of Acquisition } \\
\end{array}$ \\
\hline \multicolumn{3}{|l|}{ U.S. Oil and Gas Production } \\
\hline Burlington Resources & LaPlata, CO properties & 123 \\
\hline Coastal & $\begin{array}{l}\text { Tesoro Petroleum's interest in the Bob West Field } \\
\text { (TX) }\end{array}$ & 74 \\
\hline Ashland & Appalachian natural gas properties & 68 \\
\hline Union Pacific & $\begin{array}{l}\text { Austin Chalk (TX) properties from Edco Energy } \\
\text { and Weber Energy }\end{array}$ & 28 \\
\hline Anadarko Petroleum & Interests in the TXL field (TX) from Shell Oil & 24 \\
\hline ARCO ... & $\begin{array}{l}\text { Vastar subsidiary acquired San Juan Basin (CO) } \\
\text { properties from Destec Energy. }\end{array}$ & 22 \\
\hline ARCO ..... & Oklahoma properties from H\&H Star Energy. & 20 \\
\hline \multicolumn{3}{|l|}{ Foreign Oil and Gas Production } \\
\hline ARCO $\ldots \ldots \ldots$ & $\begin{array}{l}\text { LUKoil (Russia) bonds convertible into 6.3-percent } \\
\text { equity interest }\end{array}$ & 250 \\
\hline Mobil. . & $\begin{array}{l}\text { 10-percent interest in Block B offshore Equatorial } \\
\text { Guinea from United Meridian }\end{array}$ & 39 \\
\hline Texaco $\ldots$ & $\begin{array}{l}\text { Additional 9.8-percent interest in Texaco Canada } \\
\text { Petroleum from Canadian } 88 \text { Energy }\end{array}$ & 17 \\
\hline \multicolumn{3}{|l|}{ Refining, Marketing, and Transport } \\
\hline Ashland $\ldots \ldots \ldots$ & Zerex and Valvoline distributorships & 69 \\
\hline DuPont $($ Conoco) $\ldots \ldots \ldots \ldots \ldots$ & $\begin{array}{l}\text { 16.33-percent interest in the Czech Republic's } \\
\text { refining industry }\end{array}$ & 59 \\
\hline Enron $\ldots \ldots \ldots \ldots$ & $\begin{array}{l}\text { EOTT Energy Partners subsidiary acquired crude } \\
\text { oil pipelines from Amerada Hess }\end{array}$ & 54 \\
\hline \multicolumn{3}{|l|}{ Coal } \\
\hline Ashland . & Additional 15-percent interest in Ashland Coal & 110 \\
\hline \multicolumn{3}{|l|}{ Chemicals } \\
\hline Ashland & Various businesses from Aristech Chemical & 156 \\
\hline Occidental Petroleum & 65-percent interest in INDSPEC Chemical Corp & 85 \\
\hline \multicolumn{3}{|l|}{ Other Nonenergy } \\
\hline Union Pacific & Chicago and Northwestern Railroad & 1,200 \\
\hline Union Pacific ... & 25-percent interest in Southern Pacific & 976 \\
\hline Ashland & Various construction companies & 24 \\
\hline Amoco $\ldots \ldots \ldots \ldots \ldots \ldots \ldots \ldots$ & Plaskon Electronic Materials Co. & 19 \\
\hline
\end{tabular}

Sources: Company annual reports to shareholders, Oil and Gas Investor (September 1995 and April 1996), and various issues of Energy Alert.

percent in 1989. Since 1993, however, environmentallyrelated capital expenditures of the FRS companies ${ }^{16}$ have declined by $\$ 0.9$ billion, an amount which matched the decline in total capital expenditures for U.S. refining over the 1993-1995 period. The FRS companies' capital outlays for environmental purposes appeared to have been at a peak in 1993 and 1994 . Total environmental capital expenditures declined 17 percent between 1994

\footnotetext{
${ }^{16}$ U.S. corporations disclose their total environmentally-related capital expenditures if material, in their annual filings of Securities and Exchange Commission Form 10-K.
} 
and 1995, and 1996 expenditures are expected to decline another 29 percent among FRS companies reporting planned capital expenditures for environmental purposes.

Gasoline marketing became an area of growth subsequent to the oil price crash of 1986. Accordingly, U.S. gasoline marketing was a target of investment in the late 1980 's, as the FRS companies' capital expenditures for marketing, at $\$ 2.8$ billion in 1989 and 1990, were nearly double those preceding the 1986 oil price crash. Expenditures were directed at increasing the number of company-operated outlets (up 20 percent from 1986 to 1990) and upgrading outlets to pump more gasoline and to add more value through the addition of non-fuel retail sales. In the 1990's, gasoline demand growth slackened and so did the FRS companies' marketing commitments. Lessened demand growth and environmentally-related expenditures (primarily for leaking underground storage tanks) pressured gasoline marketers to cut costs, in part through geographic consolidation of marketing networks. The FRS marketers reduced the number of company-operated service stations by 24 percent by 1995 . Nevertheless, capital expenditures for marketing have remained in the $\$ 1.8$ to $\$ 1.9$ billion range in recent years, indicating continuing efforts to extend the scope and productivity of these operations in order to yield added value.

Capital expenditures for foreign refining and marketing exhibited a similar pattern to U.S. operations following the oil price collapse in 1986 and following massive divestitures of foreign refineries which were largely completed by 1986 . Capital expenditures steadily rose and peaked in 1991 , at $\$ 3.9$ billion, nearly double 1986 's capital outlays. Since then, capital expenditures for foreign refining and marketing have tapered off to $\$ 3.0$ billion in 1995 . The recent trend in expenditures was related in part to completion of projects to increase distillate output from retained facilities. Distillate's share of the FRS companies' foreign refined product output slate rose from 25 percent just before the oil price collapse to 42 percent in 1991, the year of peak capital spending. Since then, the distillate share has been essentially unchanged. The importance of distillate in foreign petroleum markets is underscored by the largely unchanged 29 to 30 percent share for gasoline in the FRS companies' foreign refineries over the entire 1986-1995 time span.

The modest, but steady, decline in capital spending for foreign refining and marketing obscures the shift in investment targets in recent years. Sun and Exxon shed refineries in Canada and Western Europe in 1995. In the same year, Exxon and other FRS companies were gaining refining capacity and marketing facilities in Asia, Latin
America, and Eastern Europe. See Chapter 4 for detailed discussions of these developments.

\section{Coal and Other Energy: A Variety of Investment Targets}

Interpretation of capital expenditures data for coal operations is complicated by the recent restructurings of Shell Oil and Exxon. When Shell Oil exited the U.S. coal industry in 1992 through the sale of their U.S. coal assets to Zeigler Coal, Shell gained a 25-percent equity share in Zeigler. This investment was divested in 1994, resulting in a large negative effect on reported capital expenditures for coal operations. Exxon sold their Carter Mining subsidiary in 1994, reducing their U.S. coal operations by about 80 percent. Excluding the effects of these transactions, the FRS companies' capital expenditures for U.S. coal operations were essentially unchanged at $\$ 172$ million, while capital expenditures for foreign coal operations, mainly in Australia and Colombia, were down 25 percent. The 10 FRS companies with ongoing U.S. coal production operations registered modest growth: excluding the effects of the Exxon transaction, U.S. production was up 6 percent as was their U.S. mining capacity, from 1994 to 1995.

The FRS companies' capital expenditures for other energy in 1995 reflected the attractions of electric generation abroad. In particular, Enron reported ongoing construction of electric generation facilities in China, the Dominican Republic, and Indonesia and the startup of construction on a controversial project in India. Coastal began a capacity expansion project on their heavy fuel oilpowered planted in El Salvador. Coastal also gained a 48percent interest in a company with a similarly fueled plant in the Dominican Republic. Overall, capital expenditures for other energy projects outside the United States nearly doubled from 1994 , to $\$ 327$ million.

Apart from Union Pacific's acquisitions of railroad interests in 1995, acquisitions by the FRS companies remained at a low level (Figure 9). The largest energyrelated acquisition was also the most unusual. ARCO acquired convertible bonds issued by LUKoil,Russia's largest oil producer, for $\$ 250$ million (Table 9). Other FRS companies have entered the oil and gas industries of the countries of the Former Soviet Union through direct investment in exploration and production facilities rather than through passive equity investments. Although the FRS companies made outlays of nearly $\$ 600$ million for U.S. properties with proven oil and gas reserves in 1995, they were net sellers of U.S. oil and gas reserves, as they have been for five of the past six years. 
Figure 9. Additions to Investment in Place and Value of Acquisitions and Mergers for FRS Companies, 1974-1995

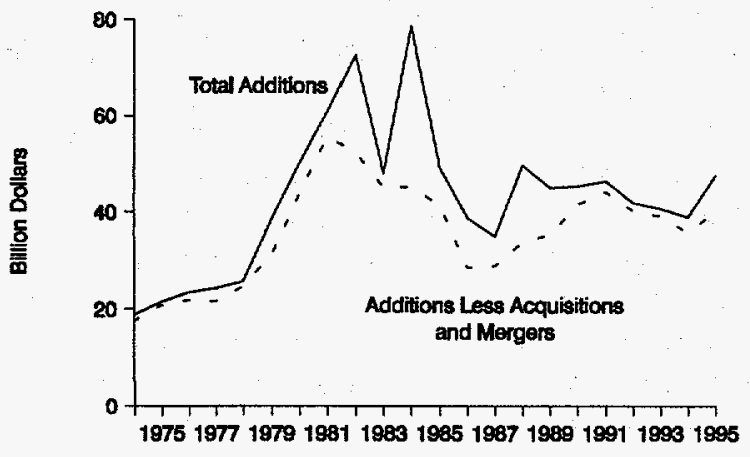

Sources: Energy Information Administration, Form EIA-28, and company filings of Securities and Exchange Commission Form 10-K.

Figure 10A. Current and Deferred Income Expense/Pretax Income, 1981-1995

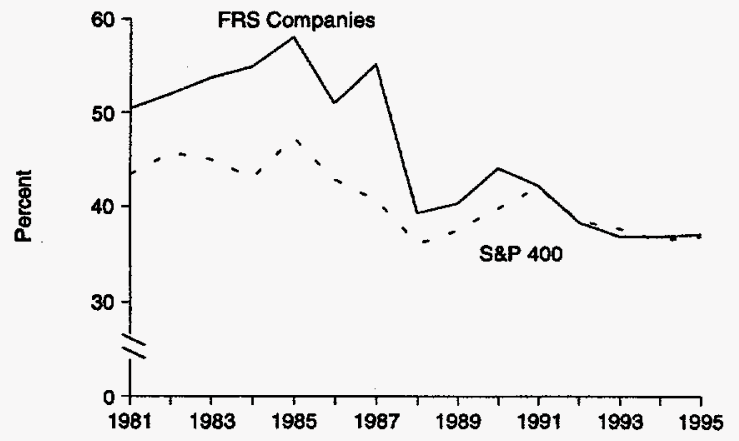

Sources: FRS Companies: Energy Information Administration, Form EIA-28. S\&P 400: Standard \& Poor's Compustat Services, Inc.

\section{Taxes}

\section{Current Taxes Increase}

Worldwide income taxes for FRS companies were 37 percent of pretax income in 1995, a slight increase from the effective rate in 1994 (Figure 10A) and virtually identical to the effective tax rate of the other large U.S. industrial corporations as represented by the S\&P 400 .

In the area of current taxes, however, a sharp divergence occurred in 1995, as the FRS companies experienced a significant increase, while the S\&P 400 companies had only a slight rise (Figure 10B). Current income taxes are those taxes deemed payable in the reporting year. ${ }^{17}$ In 1995, current income taxes for FRS companies increased 32 percent, or by $\$ 3.1$ billion, even though pretax income increased only by 16 percent (Table 10). Of the current income taxes, the State and local portion increased 23 percent-but the big increase was in the U.S. Federal

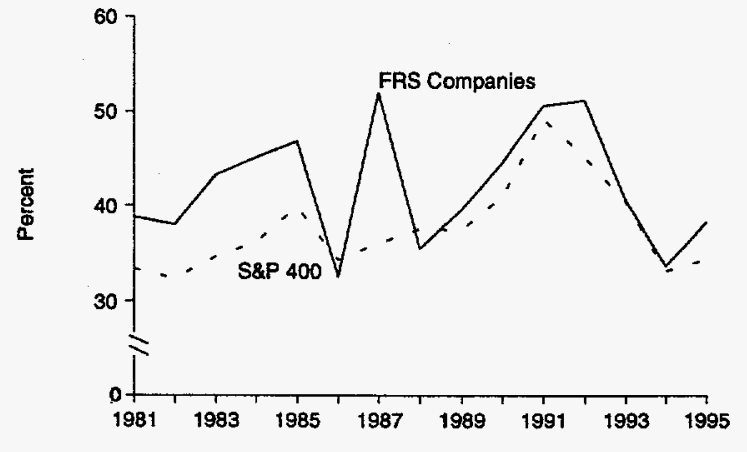

Sources: FRS Companies: Energy Information Administration, Form ElA-28. S\&P 400: Standard \& Poor's Compustat Services, inc.

\footnotetext{
${ }^{17}$ For financial reporting purposes, income taxes are categorized as current or deferred. Current taxes are deemed payable in the reporting year. Deferred taxes are differences between income tax expense accrued under Generally Accepted Accounting Principles for financial reporting purposes and income taxes currently payable in the reporting period. They originate from a variety of sources and are important to the financial operations of energy companies, as well as to industry in general. Basically, deferred taxes originate because of timing differences in reporting revenue and expense for financial reporting and tax reporting. Financial reporting attempts to match items of income and expense in the periods in which they occur. Tax reporting may permit different timing for recognizing revenues and deducting expenses. For example, faster writeoffs of depreciable properties are permitted under tax laws while they may not be acceptable under financial accounting principles. Accelerated writeoffs result in lower taxable income and thus lower tax liability in the year taken. In future periods, however, taxable income and income taxes payable may be higher than pretax income for financial reporting purposes because the timing differences between tax and financial reporting are reversed.
} 
portion, which registered an increase of $\$ 2.6$ billion (131 percent), which was widely spread across most of the FRS companies. The steep rise in Federal current taxes followed a \$1.5-billion decline in 1994, which occurred despite an increase in pretax income. Current foreign income taxes increased as well, but only by a modest 7 percent compared to taxes in 1994. The reasons for the recent upturn in Federal current taxes for FRS companies are not altogether clear, nor are the reasons for the sharp decline in Federal current taxes in 1994.

\section{Effective Tax Rate in U.S. Oil and Gas Remains Low}

Among lines of business, U.S. oil and gas production had the lowest effective tax rate in 1995 (Table 11). The effective tax rate of 20 percent for U.S. oil and gas production reflected the continued importance of "Section $29^{\prime \prime}$ tax credits, which apply to the production of certain alternative (or nonconventional) fuels. ${ }^{18}$ The San Juan Basin, located in northwest New Mexico and southwest Colorado, is where most coalbed methane is produced. Alabama and Virginia also produce significant amounts of coalbed methane and, to a lesser extent, so do Kansas,
Oklahoma, Pennsylvania, Utah, West Virginia, and Wyoming. ${ }^{19}$ On a smaller scale, FRS companies also benefitted from Enhanced Oil Recovery tax credits. ${ }^{20}$ Based on information filed with submissions of Form EIA28 (Financial Reporting System), both Section 29 and Enhanced Oil Recovery tax credits reduced the FRS companies' income taxes in U.S. oil and gas production by $\$ 586$ million in 1995 and $\$ 636$ million in 1994 . Section 29 credits are particularly attractive as the market price of gas remains low. These credits, originally set at $\$ 3$ per barrel of oil equivalent (BOE), have steadily been adjusted upward with inflation. The credit for most forms of nonconventional fuels in 1995 was $\$ 5.83$ per BOE, ${ }^{21}$ which is roughly $\$ 1.01$ per thousand cubic feet (Mcf) of gas-a significant incentive in light of the fact that the 1995 average wellhead price of natural gas was $\$ 1.59$ per $\mathrm{Mcf}^{22}$

In another tax-related development, the President signed into law the Outer Continental Shelf Deep Water Relief Act on November 28, 1995..$^{23}$ The Act, scheduled to be implemented July 1996, reduces royalties collected by the Federal government for oil produced from deep water wells. These wells are on Federally leased properties in the Outer Continental Shelf area of the Gulf of Mexico, at water depths greater than 200 meters.

\footnotetext{
${ }^{18}$ "Section 29" fuels generally include oil produced from shale and tar sands; gas produced from geopressurized brine, Devonian shale, coal seams, tight formations, or giomass; and liquid, gaseous, or solid synthetic fuels produced from coal.

${ }^{19}$ Energy Information Administration, U.S. Crude Oil, Natural Gas, and Natural Gas Liquids Reserves 1995 Annual Report, DOE/EIA-0216(95) (Washington, DC, December 1996), p. 35

${ }^{20}$ Enhanced Oil Recovery projects involve the use of tertiary methods (primarily injection of liquids or gases) in reservoirs where oil no longer can be brought up by primary or secondary (water pumping) oil recovery methods.

${ }^{21}$ Federal Register, U.S. Department of the Treasury, Internal Revenue Service, Vol. 61, No. 70, (April 10, 1996).

${ }^{22}$ Energy Information Administration, Natural Gas Monthly, DOE/EIA-0130(96/09) (Washington, DC, September 1996), p. 12.

${ }^{23}$ Outer Continental Shelf Deep Water Relief Act, Public Law No. 104-58, secs. 302-306, 109 Stat. 563-566.
} 
Table 10. Composition of Income Tax Expense for FRS Companies, 1994-1995 (Billion Dollars)

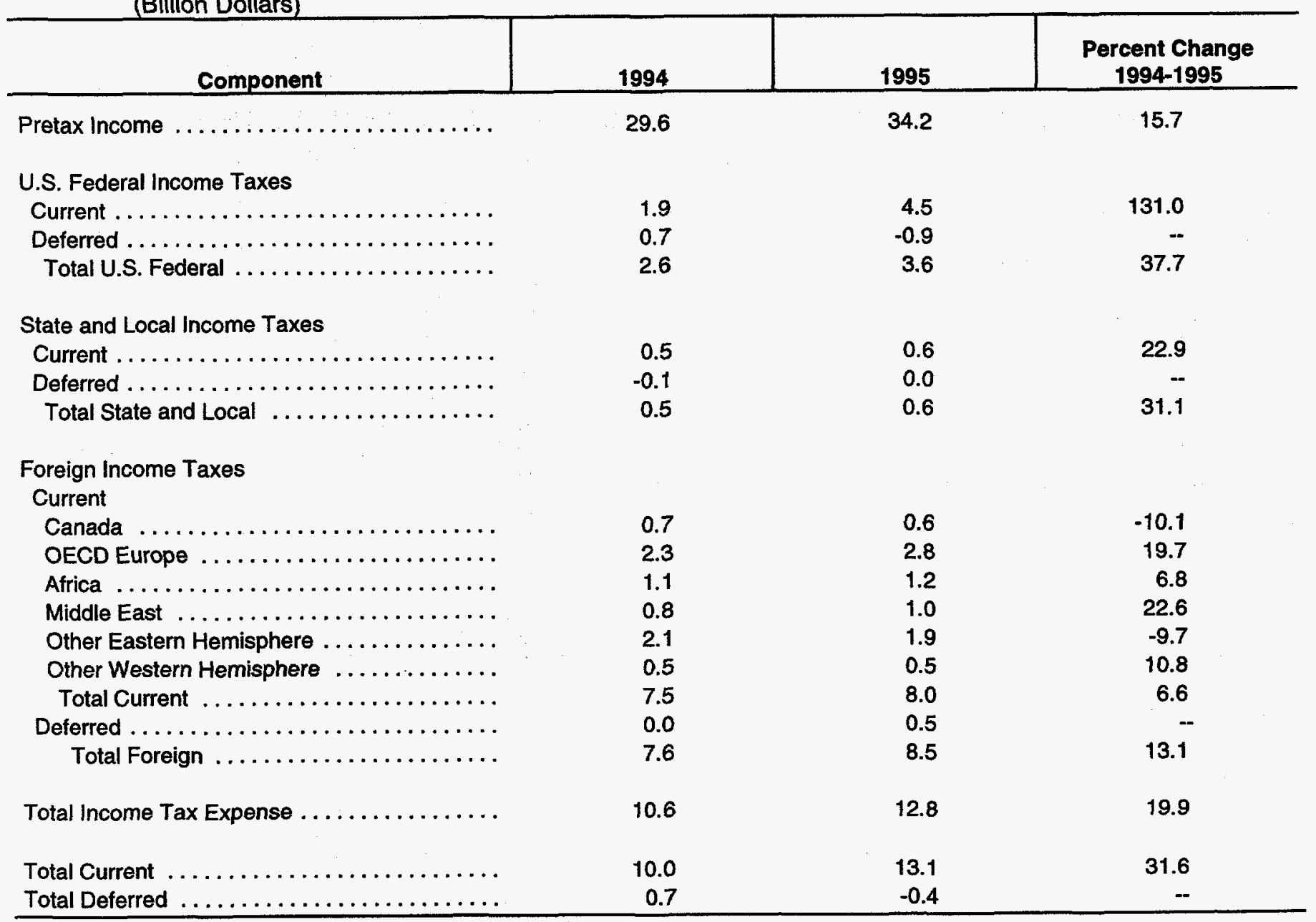

-- Not meaningful.

Note: Sum of components may not equal total due to independent rounding. The Former Soviet Union and Eastern Europe are included in OECD Europe to avoid disclosure.

Source: Energy Information Administration, Form EIA-28. 
Table 11. Income Tax Expense, Pretax Income, and Effective Tax Rates by Line of Business, 1994-1995

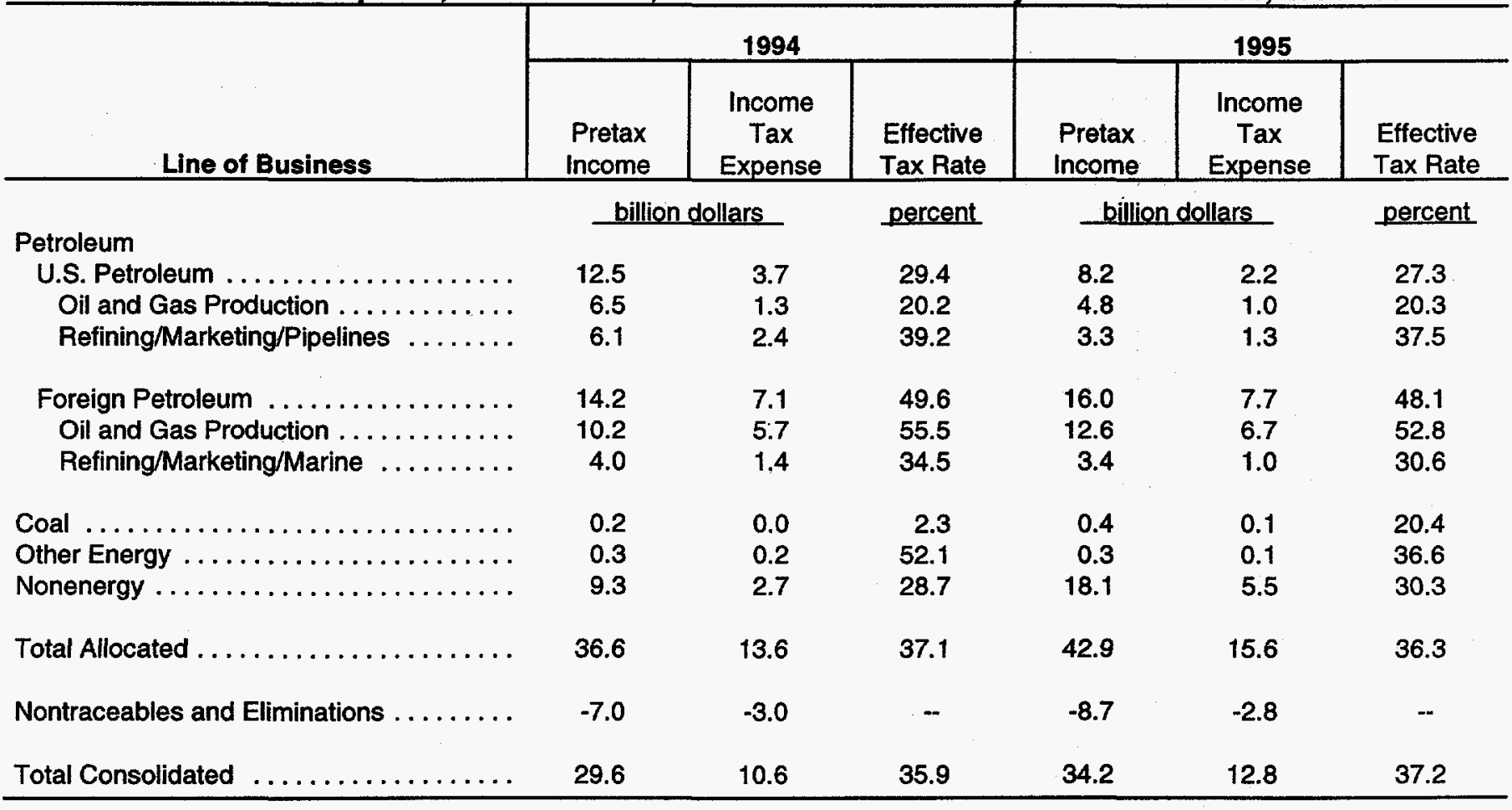

$-=$ Not meaningful.

Note: Sum of components may not equal total due to independent rounding. Effective tax rates are calculated from unrounded data.

Source: Energy Information Administration, Form ElA-28. 



\section{Oil and Gas Exploration, Development, and Production}

\section{Financial Results}

Bottom-line results for the FRS companies' U.S. oil and gas production operations in 1995 were about even with 1994's results, excluding the effects of unusual items (Table 12). On the revenue side, results improved due primarily to higher oil prices (Table 13). The drop in natural gas revenues reflected sharply lower natural gas prices in the United States during the first half of 1995. However, natural gas continued to be a source of growth for the FRS companies. As in 1994, they increased their U.S. natural gas production in 1995, reaching a level not attained since 1982. Storage, reselling, and marketing (socalled, "midstream" activities) of natural gas-beyond the field separators - have become areas of growth for an increasing number of the FRS companies. Their involvement in natural gas reselling and marketing, as measured by the difference between natural gas sales and production, has grown nearly fourfold in the 1990's so far.

Cost-cutting continued in 1995. The FRS companies trimmed their costs of extracting U.S. oil and gas ("lifting costs") once again in 1995 (Figure 11 and Table 12). Sales of higher-cost properties and application of advancing technologies, particularly horizontal drilling, underlay this trend. The FRS companies made a sizable reduction in exploration expenses in spite of the increased number of exploration wells completed, possibly benefitting from declining prices for advanced technology. The companies also managed to reduce general and administrative expenses for the fourth consecutive year. The large jump in depreciation, depletion, and amortization (DD\&A) was the result of the adoption of Financial Accounting Standard 121 (see the box in Chapter 2 entitled, "New Accounting Standard Leads to Billions in Asset Writeoffs") and was a one-time event with no effect on cash earnings.

The FRS companies' foreign upstream operations registered a sizable gain in net income in 1995 (Table 12), which was more a reflection of increased production and favorable prices (Table 13) than reduced costs. The neardoubling of FRS companies' investment in foreign exploration and development, following the oil price collapse of 1986, continued to yield increased oil and gas production in 1995. The region showing the largest increase in oil production was the North Sea, with South American locales also posting higher production as well. Offshore Europe also was, by far, the main source of added natural gas production in 1995. The FRS companies' wellhead oil prices were up by similar amounts in the United States and abroad, not a surprising result given the global nature of the market for crude oil. Unlike natural gas prices in the United States and Canada, natural gas prices outside North America increased slightly, a development which further improved the performance of foreign upstream operations. Cost-cutting was also evident in foreign upstream operations, as the FRS companies continued to reduce the cost of extracting oil and gas overseas (Figure 11).

Table 12 also includes, for the first time in this series of EIA annual reports on oil industry financial performance, an income statement for independent oil and gas producers. Independents are companies outside the FRS group that produce oil and gas and whose primary industry is Standard Industrial Classification (SIC) code 13 (Oil and Gas Production and Services). The data shown in Table 12 are for publicly-traded independents and are based on the disclosures required of oil and gas producers. As the independents' role in U.S. oil and gas production continues to grow, their financial performance becomes increasingly important in assessing the health of the U.S. oil and gas industry.

The results for independent producers' U.S. operations indicate that their net income fell more steeply than the FRS companies' net income. The source of worsened earnings of the independents was the generally larger share for natural gas in their production and revenues compared to those of the FRS companies. Unlike the FRS companies, there was no evident overall tendency to cut costs in 1995. 
Table 12. Income Components and Financial Ratios in Oil and Gas Production for FRS Companies and Independent Oil and Gas Producers, 1994-1995 (Billion Dollars)

\begin{tabular}{|c|c|c|c|c|c|c|}
\hline \multirow[b]{3}{*}{ Components of Income and Financial Ratios } & \multicolumn{4}{|c|}{ FRS Companies } & \multirow{2}{*}{\multicolumn{2}{|c|}{$\begin{array}{c}\begin{array}{c}\text { Independent } \\
\text { Producers }\end{array} \\
\text { United States }\end{array}$}} \\
\hline & \multicolumn{2}{|c|}{ United States } & \multicolumn{2}{|c|}{ Foreign } & & \\
\hline & 1994 & 1995 & 1994 & 1995 & 1994 & 1995 \\
\hline \multicolumn{7}{|l|}{ Oil and Gas Revenues } \\
\hline 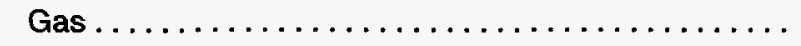 & 19.8 & 18.7 & NA & NA & 4.0 & 3.7 \\
\hline Total Revenues $\ldots \ldots \ldots \ldots \ldots \ldots \ldots \ldots$ & 43.2 & 45.0 & 34.2 & 40.5 & 6.5 & 6.8 \\
\hline \multicolumn{7}{|l|}{ Expenses } \\
\hline 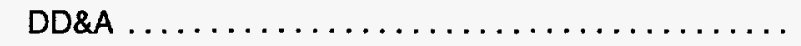 & 11.2 & 13.7 & 7.0 & 7.8 & 2.9 & 3.5 \\
\hline Lifting Costs $\ldots \ldots \ldots \ldots \ldots \ldots \ldots \ldots \ldots$ & 12.8 & 12.1 & 9.3 & 9.1 & 2.0 & 2.1 \\
\hline Other Costs (Revenues) . . . . . . . . . . . . . . & 1.3 & -2.3 & 0.1 & 0.1 & -0.1 & 0.1 \\
\hline Total Operating Expenses $\ldots \ldots \ldots \ldots \ldots \ldots$ & 37.0 & 40.7 & 25.3 & 29.6 & 5.1 & 6.0 \\
\hline Operating Income $\ldots \ldots \ldots \ldots \ldots \ldots \ldots$ & 6.2 & 4.3 & 8.9 & 10.9 & 1.5 & 0.8 \\
\hline Other Income (Expense) ${ }^{a}$ & 0.2 & 0.5 & 0.8 & 1.8 & -- & - \\
\hline Income Tax Expense $\ldots \ldots \ldots \ldots \ldots \ldots \ldots$ & 1.3 & 1.0 & 5.7 & 6.7 & 0.3 & 0.2 \\
\hline Net Income $\ldots \ldots \ldots \ldots \ldots \ldots \ldots$ & 4.8 & 3.7 & 4.0 & 5.9 & 1.2 & 0.6 \\
\hline 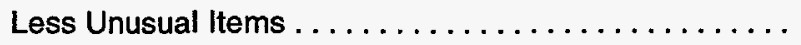 & -1.0 & -2.0 & -0.5 & -0.2 & NA & NA \\
\hline Net Income, Excluding Unusual Items . . . . . . . . . & 5.8 & 5.7 & 4.5 & 6.1 & NA & NA \\
\hline Effective Tax Rate $^{d} \ldots \ldots \ldots \ldots \ldots \ldots \ldots \ldots$ & 20.2 & 20.3 & 55.5 & 52.8 & 18.2 & 25.4 \\
\hline
\end{tabular}

${ }^{a}$ Earnings of unconsolidated affiliates and gain (loss) on disposition of assets.

${ }^{b} \mathrm{COE}=$ Crude oil equivalent. Dry natural gas was converted at 0.178 barrels of oil per thousand cubic feet.

${ }^{c}$ Net income divided by net investment in place (Net investment in place = net property, plant, and equipment plus investments and advances).

dincome tax expense divided by pretax income.

$\mathrm{NA}=$ Not available.

$--=$ Not meaningful (less than $\$ 50$ million).

DD\&A = Depreciation, depletion, and amortization costs.

Note: Sum of components may not equal total due to independent rounding. Independent producers are publicly traded companies with oil and/or natural gas production whose primary industry code is Standard Industrial Classification 13 (oil and gas production and services).

Source: FRS Companies: Energy Information Administration, Form EIA-28. Independent Producers: Compiled from Arthur Andersen \& Co., Oil and Gas Reserve Disclosures Database, 1992-1995 (Chicago, IL, 1996). 
Table 13. Average Prices, Sales, and Production in Oil and Gas for FRS Companies, 1994-1995

\begin{tabular}{|c|c|c|c|}
\hline Prices, Sales, and Production & 1994 & 1995 & $\begin{array}{c}\text { Percent Change } \\
\text { 1994-1995 } \\
\end{array}$ \\
\hline \multicolumn{4}{|l|}{ Domestic Oil and Gas Production ${ }^{a}$} \\
\hline Crude Oil and NGL (Million Barrels) & $1,593.8$ & $1,570.6$ & -1.5 \\
\hline Dry Natural Gas (Billion Cubic Feet) & $7,998.4$ & $8,055.2$ & 0.7 \\
\hline Total (Million Barrels, COE) ${ }^{b} \ldots$. & $3,017.6$ & $3,004.4$ & -0.4 \\
\hline \multicolumn{4}{|l|}{ Domestic Oil and Gas Sales Volumes } \\
\hline Crude Oil and NGL (Million Barrels) & $1,889.0$ & $1,874.9$ & -0.7 \\
\hline Dry Natural Gas (Billion Cubic Feet) & $10,810.0$ & $12,107.8$ & 12.0 \\
\hline Total (Million Barrels, COE) ${ }^{\mathrm{b}} \ldots \ldots$ & $3,813.2$ & $4,030.1$ & 5.7 \\
\hline \multicolumn{4}{|l|}{ Domestic Production Segment Per Unit Sales Values } \\
\hline Crude Oil and NGL (Dollars Per Barrel) & 12.42 & 14.03 & 12.9 \\
\hline Dry Natural Gas (Dollars Per Thousand Cubic Feet) & 1.83 & 1.54 & -15.5 \\
\hline Composite (Dollars Per Barrel COE) ${ }^{\mathrm{b}} \ldots \ldots \ldots$ & 11.34 & 11.17 & -1.5 \\
\hline \multicolumn{4}{|l|}{ Foreign Oil and Gas Production ${ }^{a}$} \\
\hline Crude Oil and NGL (Million Barrels) & $1,418.9$ & $1,434.9$ & 1.1 \\
\hline Dry Natural Gas (Billion Cubic Feet) & $4,312.1$ & $4,431.2$ & 2.8 \\
\hline Total (Million Barrels COE) ${ }^{\mathrm{b}}$ & $2,186.5$ & $2,223.7$ & 1.7 \\
\hline \multicolumn{4}{|l|}{ Foreign Production Segment Per Unit Sales Values } \\
\hline Crude Oil and NGL (Dollars Per Barrel) & 14.77 & 16.12 & 9.1 \\
\hline Dry Natural Gas (Dollars Per Thousand Cubic Feet) & 1.91 & 1.93 & 1.0 \\
\hline Canada $\ldots \ldots \ldots \ldots \ldots \ldots \ldots \ldots \ldots \ldots$ & 1.37 & 0.90 & -34.3 \\
\hline OECD Europe & 2.44 & 2.57 & 5.3 \\
\hline Other Foreign . . . . . . . . & 1.65 & 1.73 & 4.8 \\
\hline Composite (Dollars Per Barrel COE) & 13.31 & 14.16 & 6.4 \\
\hline
\end{tabular}

${ }^{2}$ Production is on a net ownership basis. Sales are domestic production segment sales. See Appendix A for discussion of FRS reporting conventions.

${ }^{b} \mathrm{COE}=$ Crude oil equivalent. Dry natural gas was converted at 0.178 barrels of crude oil per thousand cubic feet.

Sources: Energy Information Administration, Form EIA-28. Foreign production segment per unit sales values were compiled from information in FRS companies' filings of Securities and Exchange Commission Form 10-K, annual reports to shareholders, and supplements to annual reports.

\section{Oil and Gas Investment}

\section{Companies Continue Focused Strategy}

The Gulf of Mexico is a long-term investment target of the FRS companies, but in 1995 total U.S. offshore exploration and development expenditures declined slightly, due to a slowdown in drilling of gas wells (Table 14, Table B25). This decline is probably temporary, since acquisition of unproved acreage in the U.S. offshore increased by 25 percent from 1994 levels. The FRS companies nearly doubled their Federal Outer Continental Shelf (OCS) acreage awards (Figure 12). Unproved acreage acquisition is a leading indicator of oil and gas investment activity, and it can be expected that exploration and development expenditures for U.S. offshore regions will increase in the near future, as companies drill the newly-acquired acreage.

Nearly all FRS companies consider the Gulf of Mexico a key element in their upstream strategies. Mobil says: "We have narrowed our exploration focus in the United States, concentrating resources on high potential Gulf of Mexico outer continental shelf deepwater and subsalt opportunities...". ${ }^{24}$ Fina's goal is to be a low-cost finder of natural gas, geographically concentrated onshore in the Gulf coast and offshore in the Gulf of Mexico, and to selectively pursue oil opportunities which are large in size. ${ }^{25}$ For Amoco, "...development of North American

\footnotetext{
${ }^{24}$ Mobil Corporation, Annual Report 1995, p. 27.

${ }^{25}$ Fina, Inc., Annual Report 1995, p. 3.
} 
Figure 11. Direct Oil and Gas Lifting Costs for FRS Companies, 1981-1995

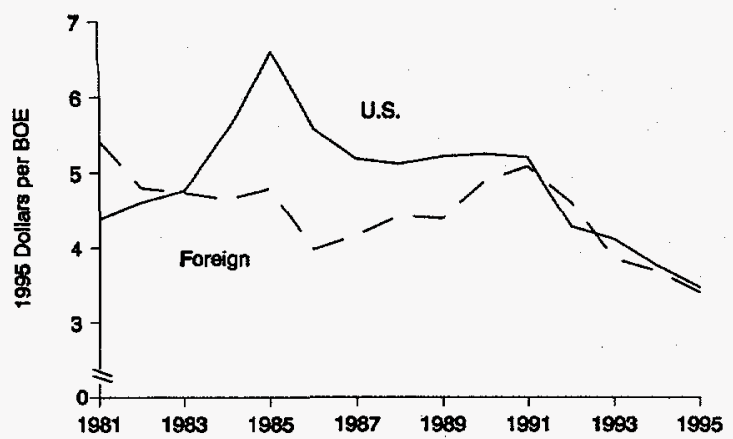

$B O E=$ Barrels of crude oil equivalent.

Source: Energy Information Administration, Form EIA-28.

natural gas resources, and deepwater and subsalt fields in the Gulf of Mexico remain a priority. ${ }^{26}$

\section{Deep in the Gulf of Mexico}

Deepwater drilling (in water over 600 feet deep) has become a new frontier due to improvements in tech- nology. In 1995, Shell and BP America began production from the Mars offshore field, the largest discovery in the Gulf of Mexico in 25 years. ${ }^{27}$ Mars produced a recordsetting 21,000 barrels per day of crude oil and 25 million cubic feet per day of natural gas in 1995 from reserves estimated at 700 million crude-oil-equivalent barrels. ${ }^{28}$ Shell initially thought that development costs for the Mars field (in over 3,000 feet of water) would be prohibitive, but improvements in tension-leg platform design and construction and modular subsea wells made the project economically viable. ${ }^{29}$ Technological advances are driving the development of Ram/Powell and Ursa, two other deepwater discoveries, and of smaller finds on the order of 30-50 million barrels. ${ }^{30}$

Elsewhere in the Gulf of Mexico, Phillips, Anadarko, and Amoco are scheduled to begin production from Mahogany, the first commercially successful well in the subsalt play. Geologists have speculated that hydrocarbons might lie below the salt (in shallow areas of the Gulf of Mexico), but the high speed of sound through salt distorted seismic images. ${ }^{31}$ Recent advances in three-dimensional seismology have enabled exploration teams to design complex programs to correct these distortions. ${ }^{32}$ The

Table 14. Exploration and Development Expenditures for FRS Companies by Region, 1994-1995 (Million Dollars)

\begin{tabular}{|c|c|c|c|}
\hline Region & 1994 & 1995 & $\begin{array}{c}\text { Percent Change } \\
1994-1995 \\
\end{array}$ \\
\hline \multicolumn{4}{|l|}{ United States } \\
\hline Onshore & 7,815 & 7,695 & -1.5 \\
\hline Offshore & 4,773 & 4,739 & -0.7 \\
\hline Total United States. & 12,588 & 12,434 & -1.2 \\
\hline \multicolumn{4}{|l|}{ Foreign } \\
\hline Canada & 1,835 & 1,899 & 3.5 \\
\hline OECD Europe . & 4,439 & 5,204 & 17.2 \\
\hline Former Soviet Union and Eastern Europe & 297 & 359 & 20.9 \\
\hline Africa & 1,392 & 2,043 & 46.8 \\
\hline Middle East $\ldots \ldots \ldots \ldots \ldots \ldots \ldots \ldots$ & 445 & 361 & -18.9 \\
\hline Other Eastern Hemisphere . . & 2,758 & 2,430 & -11.9 \\
\hline Other Western Hemisphere . & 743 & 875 & 17.8 \\
\hline Total Foreign . . . . . . . . . & 11,909 & 13,171 & 10.6 \\
\hline Total FRS . . . . . . . & 24,497 & 25,605 & 4.5 \\
\hline
\end{tabular}

Source: Energy Information Administration, Form EIA-28.

${ }^{26}$ Amoco Corporation, 1995 Annual Report, p. 15.

27 "Mars Oil Project Sets Records," Energy Report (August 12, 1996).

28x.U.S. Gulf Output Turns Corner, to Double by 2000," Reuters Financial Service (August 22, 1996); and "Deeper, Ever Deeper," Petroleum Economist (December 1995), p. SR3.

29owight Market for Deepwater Rigs Evidenced in Texaco's Long-Term Gulf Contract," Platt's Oilgram News (December 20, 1995), p. 1, and "Subsea Technology Progress Buoys Gulf of Mexico Deepwater Action," Oil and Gas Journal (September 2, 1996), p. 25.

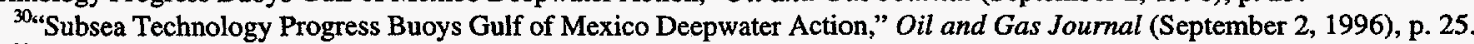

${ }^{31}$ "Understanding Salt Movement Key to Hot Gulf of Mexico Play," Oil and Gas Journal (May 2, 1994), p. 33.

${ }^{32}$ James F. Fox, Phillips Petroleum Company, Prepared Testimony before the Subcommittee on Oceanography, Gulf of Mexico and the Outer Continental Shelf, Committee on Marine and Fisheries, U.S. House of Representatives (May 19, 1994). 
Figure 12. Outer Continental Shelf Acreage Awarded, 1990-1995

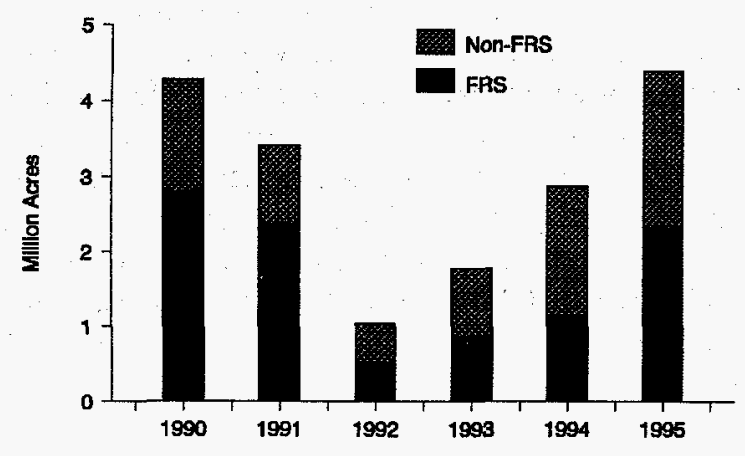

Source: Special compilation from the U.S. Department of the Interior, Minerals Management Service.

success of Mahogany validated new seismic and drilling technologies, and Anadarko plans to drill two more subsalt exploration wells and continue activity in the subsalt for several more years. ${ }^{33}$

\section{North Slope More Interesting with Lift of Export Ban}

On November 27, 1995, President Clinton lifted the 22year ban on exports of crude oil from Alaska's North Slope. The expansion of the market for Alaskan exports increases the attractiveness of Alaska as an investment target. Possibly in expectation of increased interest on the part of the petroleum companies, the State of Alaska

Figure 13A. Exploration Expenditures, 1981-1995 followed up the lifting of the ban by holding the first North Slope lease sale in two years. ${ }^{34}$ The lease sale included North Slope acreage adjacent to the currently off-limits Arctic National Wildlife Refuge (ANWR), located in the northeest corner of Alaska. Chevron and BP America are the only companies to have drilled exploratory wells inside ANWR - in the 1980's-and are also the only companies at the December sale to bid on leases near the refuge. ${ }^{35}$ Interest in Alaska contributed to the 24percent increase in FRS company expenditures for U.S. onshore acreage in 1995.

\section{North Sea, Africa Lead Foreign Expenditures}

FRS expenditures on exploration and development in foreign regions increased 11 percent from 1994, to \$13 billion in 1995 (Table 14). The nearly \$1-billion increase in exploration and development spending in the countries belonging to the Organization for Economic Cooperation and Development (OECD Europe) was led by develop ment expenditures for North Sea operations (Table 14, Figure 13A, and Figure 13B). Advances in offshore technology have increased oil and gas production from OECD Europe, in spite of the maturity of North Sea fields (Figure 14). Development strategies emphasize use of technology for producing from small fields in order to fill in the gaps and intensify production from existing infrastructures. Exxon and Chevron both expect further increases in their North Sea production, as new development projects are brought on line. ${ }^{36}$ In Africa, development expenditures also accounted for most of the increase in exploration and development spending. Mobil

Figure 13B. Development Expenditures, 1981-1995
Exploration Expenditures

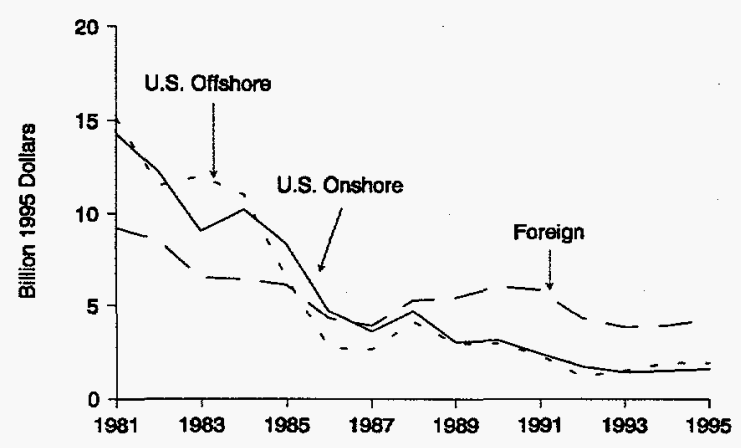

Note: Includes expenditures for unproved acreage. Source: Energy Information Administration, Form ElA-28.

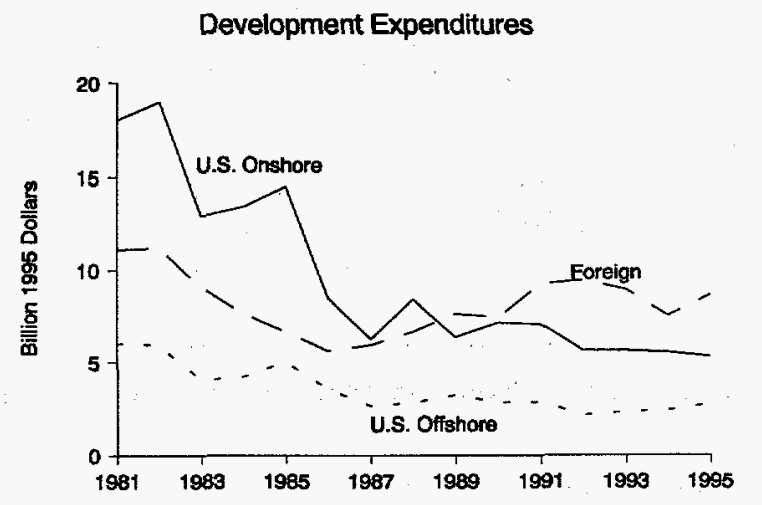

Note: Excludes expenditures for proved acreage. Source: Energy information Administration, Form EIA-28.

\footnotetext{
${ }^{33}$ Anadarko Petroleum Company, 1995 Annual Report, p. 19.

34c"North Slope Bid Round is Deemed A Success," Platt's Oilgram News (December 6, 1995), p. 1.

${ }^{35}$ "Chevron an Old Face for New Drill Near Alaskan Preserve," San Francisco Business Times (December 15, 1995), p. A-3.

${ }^{36}$ Exxon, 1995 Financial and Operating Review, p. 33, and Chevron Corporation, 1995 Annual Report, p. 11.
} 
Figure 14. FRS Companies' Oil and Gas Production in OECD Europe, 1981-1995

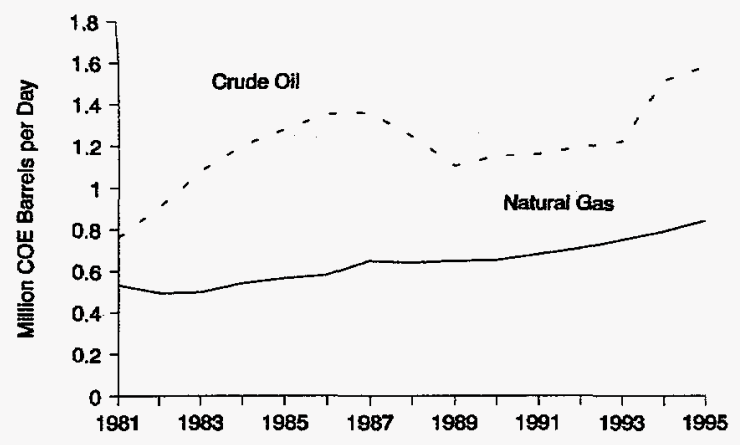

Source: Energy Information Administration, Form EIA-28.

replaced over 300 percent of its Nigerian offshore production in 1995 and accelerated development of a prospect in the Gulf of Guinea. ${ }^{37}$ Chevron also reported aggressive development of its resources in Nigeria. ${ }^{38}$

\section{Well Completions Favor Gas in United States, Oil In Canada}

The FRS companies' focus on developing natural gas reserves was evident in 1995, when they completed a record number of onshore natural gas wells in the United States (Table 15). In Canada, higher oil prices and lower gas prices in 1995 reversed drilling trends from those of 1994. The FRS companies drilled over 500 development oil wells in Canada in 1995, completing oil wells that had been on hold while resources had earlier been diverted to gas drilling. Amoco, one of the largest FRS producers in Canada, mentioned intentions to slow natural gas reserve additions, citing the "changing market environment for natural gas. ${ }^{\prime 39}$ Oil well completions in OECD Europe reflected development drilling in the North Sea. Other areas of interest in 1995 were Venezuela, where Occidental's drilling doubled production from an enhanced oil recovery project (see the box entitled "Upstream In Venezuela"). Occidental planned to drill new development wells in Colombia in 1995 but has been plagued by sabotage from leftist guerillas. ${ }^{40}$ In the Other Eastern Hemisphere region, gas well completions returned to 1993 levels. Exxon accelerated its natural gas projects offshore of Malaysia and Australia, scheduled to begin production in 1997. ${ }^{41}$ Also in Australia, DuPont drilled 18 natural gas wells in coalbed methane. ${ }^{42}$

\section{Finding Costs, Lifting Costs, and Reserve Additions}

\section{Finding Costs Reach Record Low}

Finding costs are defined as exploration and development expenditures, excluding expenditures on proved reserves,

Table 15. Well Completions by Region for FRS Companies, 1993-1995

\begin{tabular}{|c|c|c|c|c|c|c|}
\hline \multirow[b]{2}{*}{ Region } & \multicolumn{3}{|c|}{ Oil Wells } & \multicolumn{3}{|c|}{ Gas Wells } \\
\hline & 1993 & 1994 & 1995 & 1993 & 1994 & 1995 \\
\hline \multicolumn{7}{|l|}{ United States } \\
\hline Onshore .. & 2,074 & 2,081 & 2,012 & 1,791 & 2,032 & 2,358 \\
\hline Offshore & 147 & 163 & 184 & 140 & 167 & 149 \\
\hline Total United States & 2,221 & 2,244 & 2,196 & 1,931 & 2,199 & 2,506 \\
\hline \multicolumn{7}{|l|}{ Foreign } \\
\hline Canada & 383 & 216 & 636 & 340 & 522 & 264 \\
\hline Europe $^{a}$ & 72 & 74 & 94 & 43 & 36 & 40 \\
\hline Other Eastern Hemisphere & 133 & 127 & 106 & 79 & 60 & 77 \\
\hline Other $^{b} \ldots \ldots \ldots$ & 176 & 213 & 249 & 8 & 12 & 17 \\
\hline Total Foreign . & 763 & 630 & 1,085 & 470 & 630 & 397 \\
\hline
\end{tabular}

${ }^{a}$ Europe includes OECD Europe, Eastern Europe, and the Former Soviet Union.

${ }^{b}$ Other regions include Africa, the Middle East, and Other Western Hemisphere.

Note: Sum of components may not equal total due to independent rounding.

Source: Energy Information Administration, Form ElA-28.

${ }^{37}$ Mobil Corporation, Annual Report 1995, p. 32.

${ }^{38}$ Chevron, Supplement to the Chevron Corporation Annual Report 1995, p. 18.

${ }^{39}$ Amoco Corporation, 1995 Annual Report, p. 9.

${ }^{40 x}$.Oil Companies Wary of Peace Offer from Colombia Guerrillas," Latin American Energy Alert (September 20, 1996); and "Oxy, Shell Plan Cano Limon Exploration," Latin American Energy Alert (May 5, 1995).

${ }^{41}$ Exxon, 1995 Financial and Operating Review, p. 35.

${ }^{42}$ DuPont, 1995 Annual Report, p. 14. 


\section{Upstream in Venezuela}

In July 1995, Venezuela approved a new profit-sharing program under which private foreign and domestic companies may form joint ventures with Petroleos de Venezuela (PDVSA). Association with PDVSA, known as one of the world's most efficiently-run state oil companies, is regarded by other oil companies as a promising avenue of investment. The Apertura Petrolera (Petroleum Opening) program offered acreage in early 1996, receiving bids from Mobil, Exxon, Shell, Texaco, Amoco, DuPont, Occidental, USX, BP, and other private and State-owned oil companies. Venezuela has also attracted private investment in the form of non-equity contracts for enhanced oil recovery projects and heavy crude production.

Low Finding Costs. The cost to PDVSA of finding petroleum averaged about $\$ 1.40$ per barrel in $1995 .^{2}$ This is substantially lower than the $\$ 2$ to $\$ 3$ per barrel finding costs incurred by the FRS companies in the Other Western Hemisphere region in the 1990's. Several reasons for this relatively low cost are the low quality of much of the Venezuelan crude, low prices of natural gas received by PDVSA, and the high productivity of exploration drilling.

Low-quality Crude and Cheap Natural Gas. Over 70 percent of Venezuela's proved reserves consist of heavy and extra heavy crude oil. This crude is cheaper than lighter oil, and PDVSA sold its crude for about \$14 per barrel in 1995 , lower than the average price of $\$ 17.24$ for crude worldwide. ${ }^{b}$ The relatively low value of PDVSA's heavy crude does not support high-cost exploration and development projects. PDVSA sold its natural gas at prices below $\$ 0.26$ per thousand cubic feet, compared to almost $\$ 2$ per thousand cubic feet earned by the FRS companies in operations outside North America and Europe. Here again, low prices do not support high-cost exploration and development.

Superior Exploration Results. PDVSA spent only 6-8 percent of its total exploration and development budget on exploration from 1991 through 1995, compared to about 25 percent for the FRS companies over the same period. PDVSA drills many fewer exploration wells than development wells, partly because exploration in Venezuela is so successful. From 1991 to 1993 (the most recent years for which PDVSA reported these figures), oil reserves added through exploration (extensions and discoveries) have been about 1 billion barrels per year, matching the 1 billion barrels added by development. Yet between 1991 and 1993, only 23 exploration wells were drilled, compared to nearly 2,000 development wells.

Low Direct Lifting Costs. Production (or lifting) costs are the costs of extracting oil and gas, and include operating (direct lifting) costs, production taxes, and royalties. PDVSA's direct lifting costs ranged between $\$ 1.19$ and $\$ 1.73$ in 1993 through 1995, compared to the FRS companies' $\$ 2$ to $\$ 3$ per barrel direct lifting costs in Latin America. ${ }^{\circ}$ However, offsetting this difference is the fact that PDVSA pays about $\$ 2$ per barrel in royalties and production taxes, compared to under $\$ 1$ per barrel paid by the FRS companies.

\footnotetext{
'Petroleos de Venezuela, SA, Annual Report 1995, pp. 84,86; and earlier editions.

betroleos de Venezuela, SA, Annual Report 1995, p. 27; and Energy Information Administration, Monthly Energy Review, DOE/EIA0035(96/06) (Washington, DC, June 1996), p. 111.

'Petroleos de Venezuela, SA, Annual Report 1995, p. 85; and earlier editions.
}

divided by reserve additions, excluding net purchases. Finding costs are typically expressed as three-year weighted averages, to smooth out volatility in discoveries and reduce the timing differences between completing a well and booking the associated reserve additions. Investors pay particular attention to finding cost as an indicator of a company's viability in oil and gas production, and the FRS companies often cite finding reserves at a low cost as an overriding investment strategy. ${ }^{43}$ In pursuit of low-cost reserve additions, Anadarko turned itself from a producer focused primarily on natural gas into an oil producer. While achieving lower finding costs, Anadarko increased its oil reserves by over 500 percent from 1990 to 1995, as its gas reserves increased only 8 percent. ${ }^{44}$ Kerr-McGee stated that its finding costs continued to be too high but aims to reduce them to an acceptable level..$^{45}$

\footnotetext{
${ }^{43}$ Amoco Corporation, Annual Report 1988, p. 4; Phillips Petroleum Company, 1993 Annual Report, pp. 5,8; and Unocal Corporation, 1994 Annual Report, pp. 4, 6.

${ }^{44}$ Anadarko Petroleum Company, 1995 Annual Report, p. 4.

${ }^{45}$ Kerr-McGee Corporation, Annual Report 1995, p. 3.
} 
In 1995, the FRS companies' finding costs reached a record low both in the United States and abroad (Table 16, Figure 15). Independent producers, who generally have higher finding costs than the FRS companies, reduced finding costs in their U.S. operations. The 11-percent decline in finding costs in 1995 for FRS worldwide operations nearly matched last year's 12-percent decline, the largest since 1989.

\section{Prospect Highgrading: Less is More}

With the decline in wellhead prices that began in the 1980 's, smaller prospects were put on the shelf or sold, and producers concentrated on larger prospects. Drilling fewer wells in the most promising prospects is referred to as "prospect highgrading." Prospect highgrading is evident in increases in the finding rate, defined as reserve additions per exploration and development well completed, including dry holes. The dramatic cutback in drilling due to prospect highgrading after the mid 1980's contributed to increased finding rates for FRS operations in the United States and abroad. The inverse relationship. between finding rate and drilling activity was particularly evident in the U.S. onshore, which was the main focus of retrenchment following the peak in oil prices in 1981
Figure 15. U.S. and Foreign Finding Costs, 1981-1995

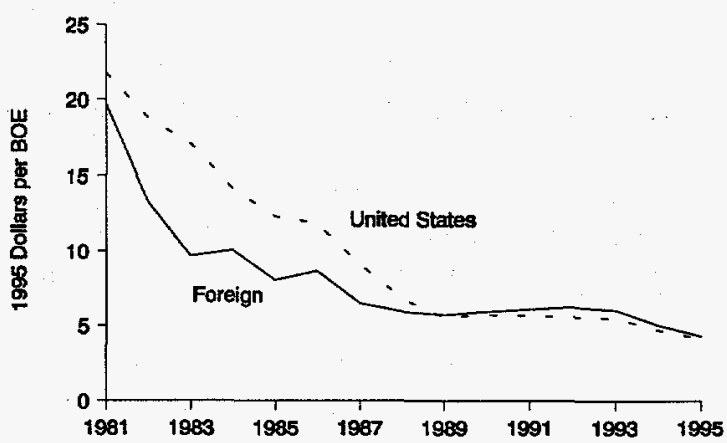

BOE $=$ Barrels of crude oil equivalent.

Note: Finding costs are 3-year weighted averages of exploration and development expenditures, excluding expenditures for proved acreage, divided by reserve additions, excluding net purchases. Reserve additions exclude BP America's and Exxon's total 1987 downward revisions of Alaska North Slope natural gas reserves of 13.461 trillion cubic feet, and Arco's 1985 downward revisions of 3.300 trillion cubic feet. Gas is converted to barrels of oil equivalent on the basis of 0.178 barrels of oil per thousand cubic feet. Gas is converted to barrels of oll equivalent on the basis of 0.178 barrels of oil per thousand cubic feet of gas.

Source: Energy Information Administration, Form ElA-28.

Table 16. Finding Costs by Region, FRS Companies and Independent Producers, 1994-1995 (Dollars per Barrel of Oil Equivalent)

\begin{tabular}{|c|c|c|c|}
\hline \multicolumn{4}{|l|}{ FRS Companies } \\
\hline \multicolumn{4}{|l|}{ United States } \\
\hline 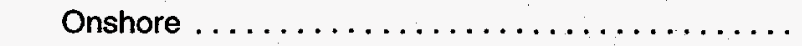 & 4.62 & 4.07 & -11.9 \\
\hline Offshore $\ldots \ldots \ldots \ldots \ldots \ldots \ldots \ldots \ldots$ & 4.38 & 4.11 & -6.1 \\
\hline \multicolumn{4}{|l|}{ Foreign } \\
\hline Canada & 6.44 & 5.70 & -11.4 \\
\hline OECD Europe $\ldots \ldots \ldots \ldots \ldots \ldots \ldots \ldots \ldots$ & 5.21 & 4.71 & -9.7 \\
\hline 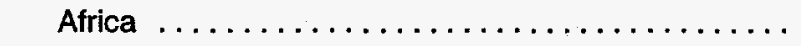 & 3.52 & 2.99 & -15.0 \\
\hline Middle East $\ldots \ldots \ldots \ldots \ldots \ldots \ldots \ldots \ldots$ & 3.88 & 2.88 & -25.7 \\
\hline Other Eastern Hemisphere $\ldots \ldots \ldots \ldots \ldots \ldots \ldots$ & 4.96 & 4.94 & -0.5 \\
\hline \multicolumn{4}{|l|}{ Independent Producers } \\
\hline United States . . . . . . . & 5.61 & 5.40 & -3.7 \\
\hline Foreign $\ldots \ldots \ldots \ldots \ldots \ldots \ldots \ldots \ldots \ldots$ & 5.23 & 5.41 & 3.4 \\
\hline
\end{tabular}

Note: The above figures are 3-year weighted averages of exploration and development expenditures, excluding expenditures for proved acreage, divided by reserve additions, excluding net purchases. Gas is converted to barrels of oil equivalent on the basis of 0.178 barrels of oil per thousand cubic feet of gas.

Sources: FRS companies: Energy Information Administration, Form EIA-28; Independent producers: compiled from Arthur Andersen \& Co., Oil and Gas Reserves Disclosures Database, 1992-1995 (Chicago, IL, 1996). Independent producers are publicly traded companies other than the FRS companies, whose primary industry code is SIC 13. 
(Figure 16). During the early 1980's, the FRS companies drilled about 9,000 U.S. onshore wells per year, with finding rates of under 250 thousand barrels per well. By the early 1990 's the companies had cut back to about 5,000 wells per year, with finding rates of about 350 thousand barrels per well. In offshore regions, drilling fell from over 800 wells per year to under 500 , with finding rates increasing from about $1,000,000$ to $2,500,000$ barrels per well. In foreign regions, a similar relationship prevailed.

\section{Figure 16. Finding Rates and Drilling Levels, FRS Companies, U.S. Onshore, 1981-1995}

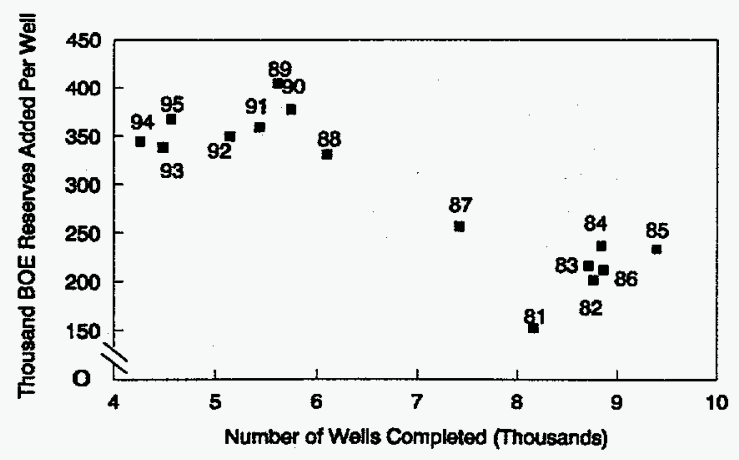

BOE = Barrels of crude oil equivalent.

Source: Energy Information Administration, Form EIA-28.

In the 1990's, however, the onshore finding rate has not changed much despite a continuing cutback in drilling activity. Nevertheless, onshore finding costs declined during the 1990's. Factors other than increased finding rates, such as innovations in technology, seem to be playing an increasingly important role in reducing finding costs. Amoco cited a dramatic example of cost reductions from new technology: "Improvements in 3-D seismic technology have allowed Amoco to cut its cycle time for exploration surveys dramatically; what used to take from three months to one year may now take two weeks to two months, saving $\$ 200,000$ to $\$ 1.2$ million per month. ${ }^{\prime 46}$

\section{Lifting Costs Decline}

Production (or lifting) costs are the out-of-pocket costs of extracting oil and gas, and include operating (direct lifting) costs, as well as production taxes and related payments. Several regions typically have high direct lifting costs per barrel, either because field sizes are small (as in Canada and the lower-48 onshore United States), or because production equipment is expensive to operate (as in the North Sea). Direct lifting costs for FRS domestic operations declined about 6 percent from 1994 to 1995, as did foreign direct lifting costs (Table 17). Technical advances such as horizontal drilling allow faster drainage of certain geological structures, reducing lifting costs. Though a horizontal well typically costs 1.5 to 2.5 times more than a vertical well, it can produce two to five times more oil per day. ${ }^{47}$

Production taxes are levied on the value of oil and gas produced, so rising prices increase the value of production, increasing the effective tax rate per barrel. Production taxes in 1995 were about level with 1994 in the United States and Canada, as declining gas prices offset increasing oil prices. Outside of North America, higher oil and gas prices led to higher production taxes in 1995.Reserve Additions Reach Record High

In 1995, the FRS companies added 6.1 billion crude-oilequivalent barrels to their worldwide reserves of oil and gas through exploration and development efforts, a record level (Table 18). ${ }^{48}$ These additions continue to reflect the FRS companies' investment in offshore and foreign regions, and their focus on natural gas. The 571 million barrels of oil added to the companies' U.S. offshore reserves set an FRS record, as did the 6,155 billion cubic feet of natural gas added to the companies' U.S. onshore reserves. Other record-setting reserve additions for the FRS companies were in OECD Europe (729 million barrels of oil) and Africa (585 million barrels of oil).

The FRS companies replaced more oil reserves than they produced in all regions except in the U.S. onshore region. However, the large ratio of natural gas reserve additions to production reflects expectations of increases in demand both in the United States and abroad.

\footnotetext{
${ }^{46}$ Amoco Corporation, 1995 Annual Report, p. 11.

${ }^{47}$ Occidental Petroleum Corporation, Annual Report 1995, p. 6.

${ }^{48}$ Record-setting reserve additions refer to the period 1977-1995. The change in reserves equals the sum of reserve additions for U.S. onshore, U.S. offshore, and foreign operations. Natural gas reserve additions need to be converted to their crude oil equivalent value by the following conversion factor: 1 billion cubic feet of natural gas equals .177 million barrels of oil equivalent.
} 
Table 17. Lifting Costs by Region, FRS Companies and Independent Producers, 1994-1995 (Dollars Per Barrel of Oil Equivalent)

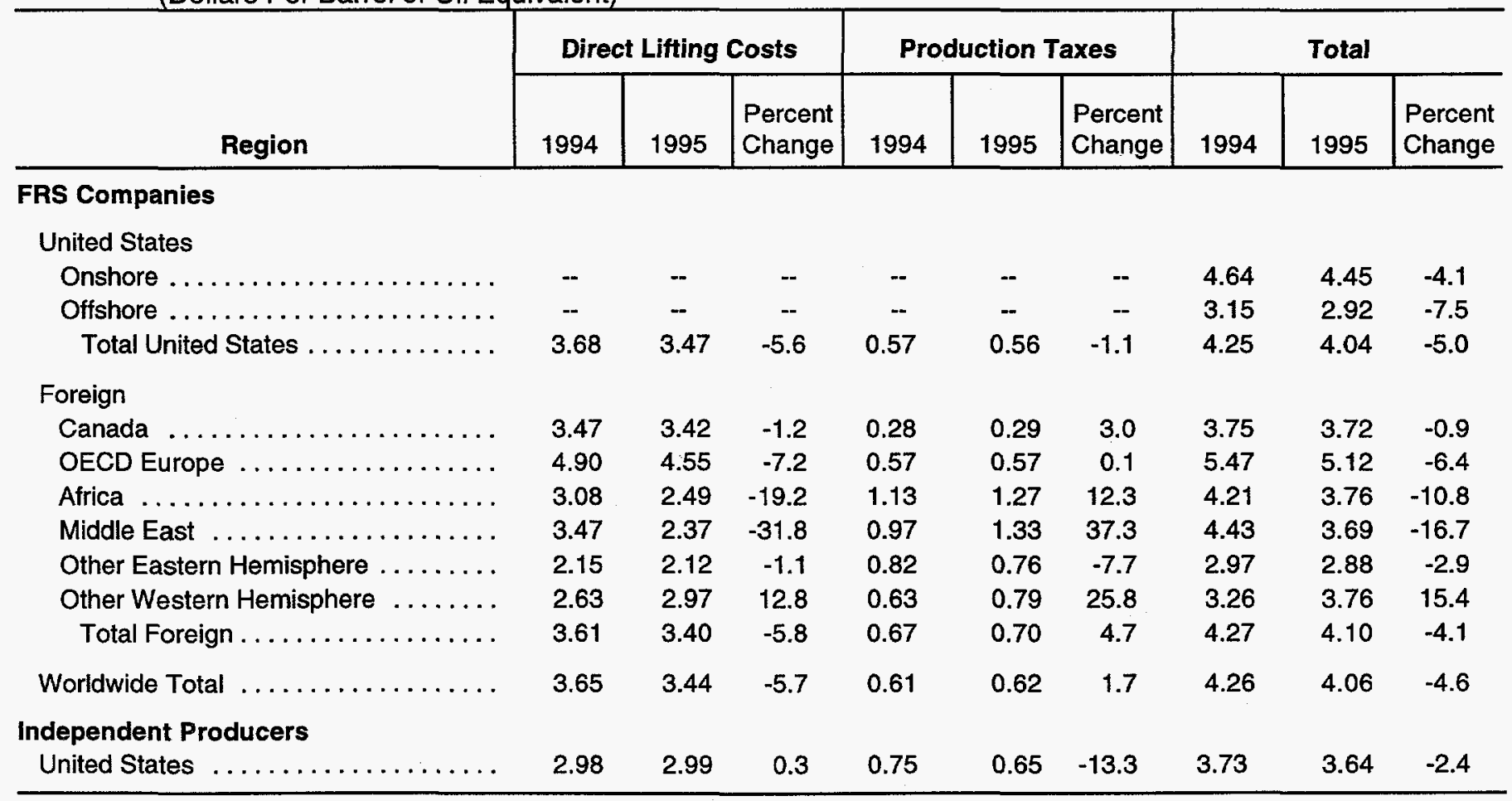

-- = Data not available.

Note: Sum of components may not equal total due to independent rounding.

Source: FRS companies: Energy Information Administration, Form EIA-28. Independent producers: compiled from Arthur Andersen \& Co., Oil and Gas Reserves Disclosures Database, 1992-1995 (Chicago, IL, 1996). Independent producers are publicly traded companies other than the FRS companies, whose primary industry code is SIC 13.

Table 18. Oil and Gas Reserves and Production for FRS Companies, 1994-1995

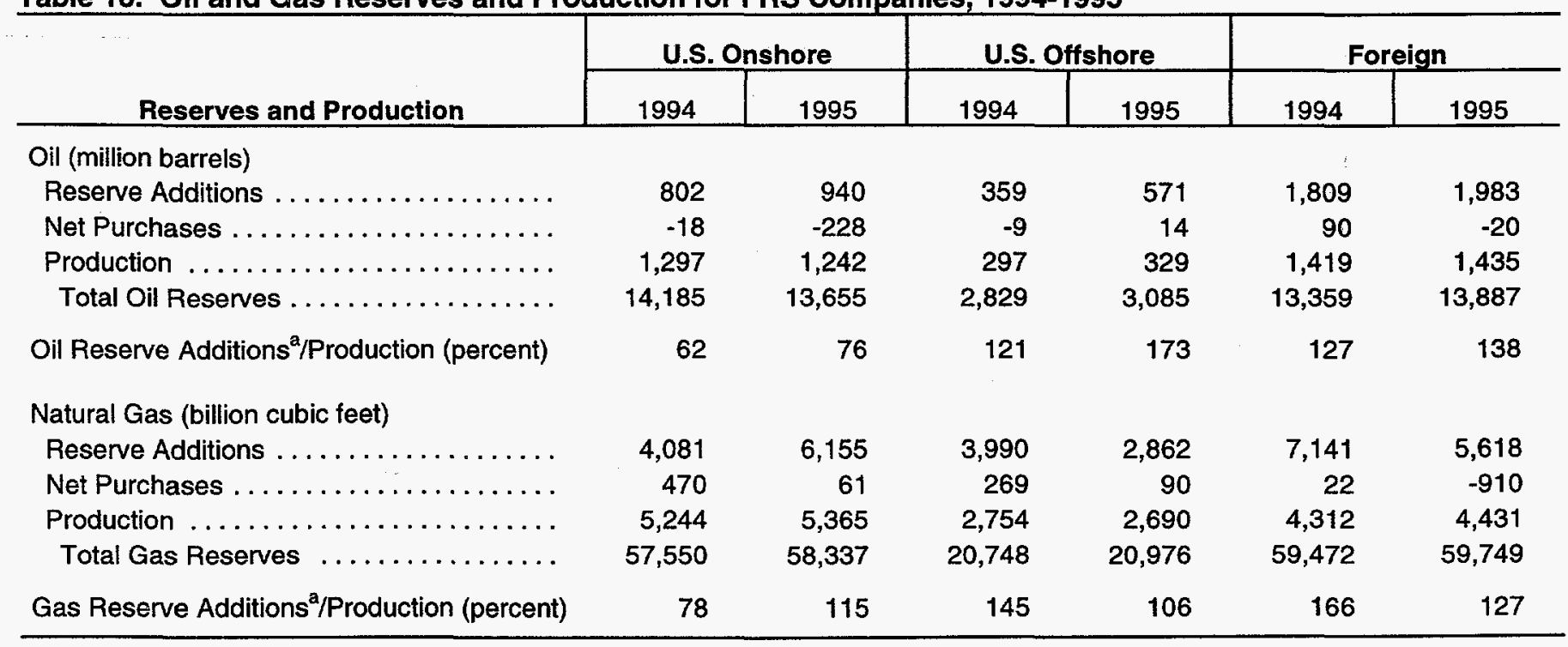

${ }^{a}$ Excludes net purchases and sales.

Note: Sum of components may not equal total due to independent rounding.

Source: Energy Information Administration, Form EIA-28. 


\section{Downstream Petroleum in 1995}

\section{Financial Results}

For the FRS companies' U.S. refining and marketing operations, 1995 was again a year of weak profitability and selective retrenchment. Gross margins on refined products ${ }^{49}$ reached historic lows, resulting in near-zero profitability for the FRS companies' downstream operations, the third lowest level in almost two decades (Figure 17). Several domestic refineries were sold in 1995, reducing the FRS companies' U.S. refining capacity by roughly 250,000 barrels per day (Table 19 ).

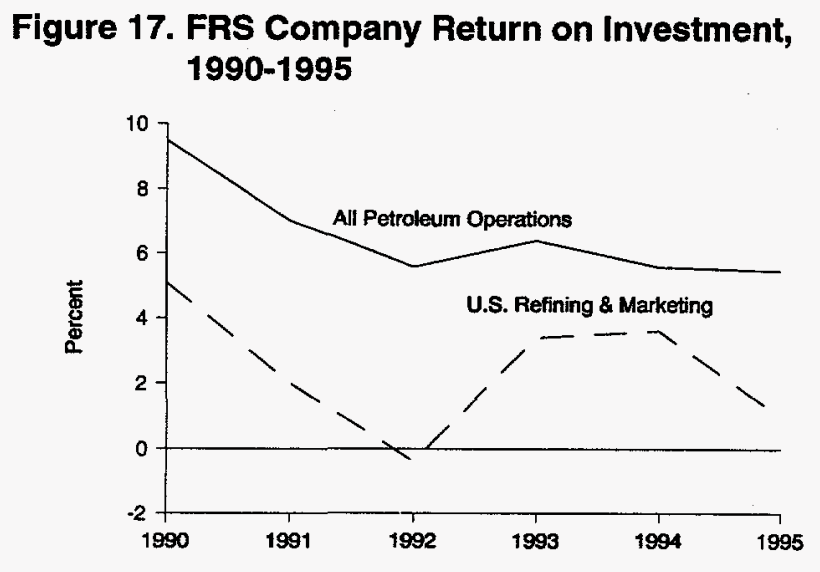

Source: Energy Information Administration, Form EIA-28.

In contrast, the profitability of the FRS companies' foreign downstream operations, though average compared to other lines of business overall, was far higher than domestic refining/marketing profitability. In recent years - both overseas and in the United States-petroleum companies (both majors and independents) have increasingly engaged in joint ventures and mergers of downstream operations in an attempt to cut costs, rationalize operations, and restore the profitability of their petroleum product refining and marketing enterprises. Further, the FRS companies have for several years been engaged in a selective expansion overseas, and in 1995 this trend continued. While the FRS companies have been continuing to scale back their operations located in the more mature petroleum product markets of North America and Europe, some regional markets-particularly in the more rapidly growing economies of Asia and Latin America-have become targets of expansion.

\section{U.S. Refining}

For the sixth consecutive year, the FRS companies' financial performance in domestic refining/marketing was generally below that of other petroleum operations (Figure 17). The FRS companies reported a 1.0-percent rate of return for their U.S. refining/marketing operations, the third poorest financial performance since at least 1977. The largest component of refined product demandmotor fuels-was decidedly robust in 1995, and refined product prices were somewhat higher. However, the rise in product prices did not match the rise in crude oil input costs. The resulting squeeze on margins was in part due to the depressing effects an unusually warm winter had on first-quarter heating fuel demand and to complications arising from the introduction of reformulated gasolines (Table 20). As a consequence, low gross refined product margins continued to depress earnings in 1995. Further, continued company efforts to reduce refining and marketing operating costs were partially offset by increased environmentally-related expenses.

\section{Gasoline Market Developments Had Mixed Effects}

Growth in the FRS companies' refined product sales was largely a reflection of a growing U.S. economy. Gasoline sales volumes increased 3 percent and product prices were 4 percent higher than those in 1994 (Table 20). Domestic downstream revenues rose from $\$ 114.8$ billion in 1994 to $\$ 120.7$ billion in 1995 (Table 21).

\footnotetext{
${ }^{49}$ The gross margin is the difference between the composite wholesale product price and the composite refiner acquisition cost of crude oil.
} 
Table 19. Refining and Marketing Investment and Operating Data for FRS Companies, 1994-1995

\begin{tabular}{|c|c|c|c|}
\hline Financial Items & 1994 & 1995 & $\begin{array}{c}\begin{array}{c}\text { Percent Change } \\
1994-1995\end{array} \\
\end{array}$ \\
\hline & \multicolumn{2}{|c|}{ (billion dollars) } & \\
\hline \multicolumn{4}{|l|}{ Additions to Investment in Place } \\
\hline Refining $\ldots \ldots \ldots \ldots \ldots \ldots$ & 4.2 & 3.6 & -14.0 \\
\hline Marketing ${ }^{\mathrm{a}} . . . .$. & 2.1 & 2.2 & -1.8 \\
\hline$\ldots \ldots \ldots \ldots \ldots \ldots$ & 6.3 & 5.8 & -8.7 \\
\hline Foreign Refining and Marketing & 3.1 & 3.0 & -4.9 \\
\hline Total .................... & 9.4 & 8.7 & -7.5 \\
\hline & \multicolumn{2}{|c|}{ (thousand barrels per day) } & \\
\hline \multicolumn{4}{|l|}{ Refining Capacity } \\
\hline United States ... & 10,669 & 10,427 & -2.3 \\
\hline Foreign ........ & 4,766 & 4,751 & -0.3 \\
\hline Total ........... & 15,435 & 15,178 & -1.7 \\
\hline \multicolumn{4}{|l|}{ Refinery Utilization Rate } \\
\hline$\ldots \ldots \ldots \ldots \ldots \ldots \ldots \ldots$ & 91.7 & 91.7 & - \\
\hline 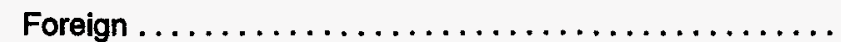 & 81.0 & 83.3 & - \\
\hline
\end{tabular}

alncludes refining and marketing transport.

$--=$ Not meaningful.

Note: Sum of components may not equal total due to independent rounding. Percent changes were calculated from unrounded data.

Source: Energy Information Administration, Form EIA-28.

Table 20. Sales, Expenses, and Income in U.S. Refining/Marketing for FRS Companies, 1994-1995

\begin{tabular}{|c|c|c|c|}
\hline Sales, Expenses, and Income & 1994 & 1995 & $\begin{array}{c}\text { Percent Change } \\
1994-1995 \\
\end{array}$ \\
\hline & \multicolumn{2}{|c|}{ (million barrels per day) } & \\
\hline \multirow[t]{2}{*}{ Refined Product Sales } & 13.5 & 13.6 & 1.4 \\
\hline & \multicolumn{2}{|c|}{ (dollars per barrel) } & \\
\hline \multicolumn{4}{|l|}{ Average Sales Price } \\
\hline Gasoline. & 26.01 & 27.13 & 4.3 \\
\hline Distillate & 21.96 & 22.14 & 0.8 \\
\hline$\ldots \ldots \ldots \ldots$ & 19.78 & 20.77 & 5.0 \\
\hline$\ldots \ldots \ldots \ldots \ldots \ldots \ldots \ldots \ldots$ & 23.37 & 24.24 & 3.7 \\
\hline Raw Material Input and Product Purchases per Barrel ..... & 17.40 & 18.71 & 7.5 \\
\hline \multicolumn{4}{|l|}{ Average Sales Price Less Cost of Raw Materials } \\
\hline and Product Purchases (Gross Margins) ....... & 5.97 & 5.53 & -7.4 \\
\hline Direct Operating Costs & 5.26 & 5.04 & -8.5 \\
\hline Refined Product Margin & 0.71 & 0.49 & -30.1 \\
\hline
\end{tabular}

${ }^{2}$ See Appendix B, Table B48, for the components to calculate the refined product margin.

$--=$ Not meaningful.

Note: Sum of components may not equal total due to independent rounding. Percent changes were calculated from unrounded data.

Source: Energy Information Administration, Form EIA-28. 
Table 21. Refining/Marketing Financial Items for FRS Companies, 1994-1995 (Million Dollars)

\begin{tabular}{|c|c|c|c|c|}
\hline & \multicolumn{2}{|c|}{ United States } & \multicolumn{2}{|c|}{ Foreign } \\
\hline & 1994 & 1995 & 1994 & 1995 \\
\hline Refined Product Revenues ... & 114,790 & 120,698 & 117,290 & 124,615 \\
\hline plus Other Revenues ${ }^{a} \ldots$ & 11,390 & 11,146 & 3,877 & 4,737 \\
\hline minus Total Operating Expenses ${ }^{a, b}$. & 122,491 & 129,777 & 117,000 & 126,271 \\
\hline equals Operating Income ${ }^{b}$ & 3,689 & 2,067 & 4,167 & 3,081 \\
\hline Net Income, excluding unusual items $\ldots .$. & 2,290 & 1,220 & 2,743 & 2,673 \\
\hline Unusual Items $\ldots \ldots \ldots \ldots \ldots \ldots \ldots$ & -445 & -712 & -746 & -264 \\
\hline Net Income $\ldots \ldots \ldots$ & 1,845 & 508 & 1,997 & 2,409 \\
\hline \multicolumn{5}{|l|}{ Ratios } \\
\hline Rate of Return ...... & 3.6 & 1.0 & 6.1 & 7.2 \\
\hline Effective Tax Rate $\ldots \ldots \ldots \ldots \ldots \ldots \ldots$ & 41.3 & 39.1 & 35.0 & 30.5 \\
\hline
\end{tabular}

${ }^{a}$ Raw material revenues are netted against total operating expense.

${ }^{b}$ Excludes unusual items.

Source: Energy Information Administration, Form EIA-28.

However, the winter of 1995 was one of the warmest on record and the number of heating degree days was 13 percent below those of the first quarter of $1994 . .^{50}$ As a result, heating oil demand was 7 percent lower in the first quarter of 1995 than in the same quarter one year earlier. Additionally, residual fuel oil consumption declined 29 percent from consumption in the first quarter of 1994. Although all sectors of the U.S. economy showed a decline in demand for residual fuels, demand at electric utilities was particularly off, as lower natural gas prices encouraged a move away from residual fuel.

Although gasoline demand grew in 1995, gasoline market turmoil in the first quarter contributed to the deterioration in U.S. refiners' bottom-line results. The Clean Air Act Amendments of 1990 mandated the introduction of reformulated gasoline (RFG) in almost a third of the U.S. gasoline market. The first quarter of 1995 marked the first full quarter of the introduction of reformulated gasoline into mandated regions. However, early demand for RFG failed to measure up to expectations as several East Coast regions unexpectedly withdrew ("opted out") from earlier commitments to voluntarily participate in ("opt into") the RFG program. The resulting drop in RFG demand created an excess supply of RFG, leading to depressed RFG prices. During the first quarter of 1995, excess supplies of RFG had a negative impact on downstream earnings of several companies-particularly those with a large marketing presence on the East Coast. Eleven of the FRS companies reported financial results for their U.S. refining/ marketing segment for the first quarter of 1995 . As a group, these companies reported that net income from their domestic refining operations declined 97 percent from the first quarter of $1994 .{ }^{51}$

\section{Operating Costs Reduced as Environmental Expenses Rise}

For several years, in the face of relatively low gross refining margins, the FRS companies have trimmed operating costs. In 1995, the FRS companies were again able to reduce all categories of operating costs (Table 22). Marketing costs per barrel sold (which cover costs related to canning and blending operations, advertising, and credit cards) were down 10 cents. Other supply costs and other refining costs (which cover certain taxes, crude oil exchange differentials, inventory changes, and transportation) were also lower than they were in 1994. Even with a substantial gain in crude oil prices, refinery energy costs were also reduced. Joint ventures appear to be another strategy the FRS companies are pursuing in an effort to reduce their operating costs. (For a discussion on

\footnotetext{
50، Asia/Pacific Refineries Spark Growth in Conversion Capacity," The Oil and Gas Journal (December 18, 1995), pp. 41-90.

${ }^{51}$ Energy Information Administration, U.S. Energy Industry Financial Developments 1995 First Quarter, DOE/EIA-0543(95/1Q) (Washington, DC, June 1995), p. 10.
} 
Table 22. FRS U.S. Refined Product Margins and Costs per Barrel Sold, Selected Years, 1979-1995 (1995 Dollars per Barrel)

\begin{tabular}{|c|c|c|c|c|c|c|}
\hline & 1979 & 1984 & 1988 & 1992 & 1994 & 1995 \\
\hline $\begin{array}{l}\text { Gross Margin }{ }^{\mathrm{a}} \ldots \ldots \ldots \ldots \ldots \ldots \\
\text { less }\end{array}$ & 8.21 & 8.37 & 8.52 & 7.39 & 6.11 & 5.53 \\
\hline Marketing Costs . & 1.95 & 2.63 & 1.96 & 2.90 & 1.85 & 1.75 \\
\hline Energy Costs $\ldots \ldots \ldots \ldots \ldots \ldots \ldots \ldots \ldots$ & 2.04 & 2.78 & 1.33 & 1.21 & 0.98 & 0.82 \\
\hline $\begin{array}{l}\text { Other Operating Expense } \ldots \ldots \ldots \ldots \ldots \ldots \ldots \\
\text { equals }\end{array}$ & 2.75 & 2.95 & 3.02 & 2.88 & 2.56 & 2.47 \\
\hline FRS Refined Product Margin ${ }^{b}$ & 1.65 & 0.01 & 2.22 & 0.41 & 0.72 & 0.49 \\
\hline Refined Product Sales Volume $(\mathrm{mbd}) \ldots \ldots \ldots$ & 14,868 & 12,088 & 14,114 & 13,089 & 13,455 & 13,641 \\
\hline
\end{tabular}

${ }^{a}$ Refined product revenues less raw material and product purchases divided by refined product sales volume.

${ }^{b}$ Calculated from unrounded data.

Note: Years shown prior to 1994 are successive peak and trough years of U.S. refining/marketing profitability.

$\mathrm{Mb} / \mathrm{d}=$ Thousand barrels per day.

Source: Energy Information Administration, Form EIA-28.

recent FRS company joint ventures, see the box entitled "A New Wave of Joint Ventures.")

Although FRS companies have been able to reduce their operating costs substantially, heightened environmental standards have been a source of upward pressure on the FRS companies' refining and marketing costs in the 1990's. Most of these standards and regulations originate from the Clean Air Act of 1970 and subsequent environmental legislation, such as the Clean Air Act Amendments of 1990 , the most far-reaching of environmental legislation since the 1970 act. These amendments presented the U.S. refining industry with a series of additional requirements to be met through the year 2000 .

Compliance with pollution abatement laws has resulted in additional operating expenses and capital expenditures. In 1994, the last year for which the Bureau of the Census published environmental cost and expenditure data, environmentally-related operating costs totaled $\$ 1.9$ billion and were 10 percent of total refining operating costs (Figure 18), the highest share since at least $1977 .{ }^{52}$

\section{Refinery Investment: Capacity Expansion and Consolidation}

Several FRS companies made additions to their existing refinery capacity in 1995 through recent capital investments. Most of these have involved debottlenecking investments. That is, refiners have been able to obtain additional refining capacity from the same physical structure, largely through a series of various incremental investments. Mobil, for one, increased its distillation capacity from 939 thousand barrels per day (b/d) to 971 thousand $b / d$ as a result of several debottlenecking investments. ${ }^{53}$ Other FRS refiners have directly expanded capacity. In 1995, Amerada Hess completed a 35,000-b/d expansion of its fluid catalytic cracking unit at its U.S. Virgin Islands refinery. ${ }^{54}$ Further, the company conducted an engineering study which concluded that the capacity of the fluid catalytic cracking unit could be increased to about $125,000 \mathrm{~b} / \mathrm{d}$ from the current $110,000 \mathrm{~b} / \mathrm{d} .^{55}$ Currently the Amerada Hess Virgin Island refinery is the largest in North America. Chevron also completed major upgrades at its two West Coast refineries, increasing its California refining capacity by $28,000 \mathrm{~b} / \mathrm{d} .^{56}$

\footnotetext{
${ }^{52}$ The denominator in this calculation excludes FRS companies' total marketing expenses even though an estimate for the marketing segment's share of the total environmentally-related marketing expense appears in the numerator. This convention was taken for two reasons. First, the data the Commerce Department provides on refining environmental expenditures does not separate refining from marketing. Secondly, according to one survey, marketing accounts for only a tenth of the total environmental-related expenditures incurred by the refining segment.

${ }^{53}$ Mobil Corporation, Mobil Fact Book 1995, A supplement to the Annual Report, p. 51.

${ }^{54}$ Oil and Gas Journal (December 18, 1995), p. 44.

${ }^{55}$ Amerada Hess Corporation, 1995 Securities and Exchange Commission Form 10-K, p. 3.

${ }^{56}$ Chevron Corporation, Chevron Supplement to the Chevron Corporation Annual Report 1994, p. 36; and Chevron Supplement to the Chevron Corporation Annual Report 1995, p. 42.
} 


\section{A New Wave of Joint Ventures}

Recently, three of the largest oil companies in the world announced that they were negotiating an alliance to combine their U.S. refining and marketing operations. The companies involved are Texaco Inc., Shell Oil (the U.S. subsidiary of Royal Dutch/Shell), and Star Enterprise (a fifty-fifty joint venture between Texaco and the state oil company of Saudi Arabia, Aramco). The combined downstream U.S. assets of the three companies equal an estimated $\$ 10$ billion.

If the planned merger is to go through it will have a major impact on the landscape of the U.S. refining and marketing industry. Shell is the largest gasoline marketer in the United States, with a 7.5-percent share of total gasoline sales. Together, Texaco and Star rank fourth, with a 7.0-percent share of the total. Currently, Shell Oil is the fifth largest refiner in the United States, while Star Enterprise ranks eighth, and Texaco, fifteenth. The combined operation would become far and away the largest refining enterprise in the United States, with eighty percent more capacity than the top ranked U.S. refiner, Chevron.

Both Shell and Texaco are involved in other downstream joint ventures. In 1993, Shell transferred a 50-percent interest in its Deer Park, Texas, refinery to Pemex, and since the 1930's both Texaco and Chevron have operated a large joint venture refining operation in the Far East, Caltex.

The proposed Shell, Texaco, and Star downstream merger follows closely on the heels of several other company announcements to merge downstream operations. In the Spring of 1996, DuPont's petroleum subsidiary, Conoco, and Phillips Petroleum also announced a proposed downstream joint venture, although discussion between the two companies later faltered. However, Phillips has publicly said that it still is interested in developing a downstream joint venture. Similarly, a top official with Amerada Hess has said that Hess is searching for a downstream joint venture partner.

These efforts are apparently motivated by the persisting low levels of profitability realized by refining operations in the United States throughout the 1990's. Cost savings is one possible motivating factor in all of these mergers, many of which (if not all) should result in labor force reductions. Also, regional concentration of marketing assets could relieve some competitive pressures on margins.

In Europe and the Far East, several notable downstream joint ventures or mergers also have been announced. The largest of these to date involves British Petroleum and Mobil, which announced early in 1996 an intent to merge their European downstream operations. The book value of the assets in this latter proposed merger is estimated at $\$ 5$ billion. BP and Mobil together sell approximately 1.4 million barrels per day of product in Europe. As a result of the merger, over 9,000 European service stations will be combined and the combined operations will account for a 12 percent share of the European retail fuel market. The merger is expected to reduce costs of the two companies by $\$ 400$ to $\$ 500$ million dollars. Furthermore, it has been speculated that the alliance may be extended to the companies' Asian operations.

Several other, although much smaller, joint ventures have recently been implemented or announced. In 1994, Texaco and Norsk Hydro, a Norwegian integrated petroleum company, created a marketing-only joint venture, which now holds the largest motor gasoline market share in Scandinavia. In 1996, Exxon and Conoco announced a joint refining venture with their Karlsruhe, Germany refineries, but stated that they would continue as competitors in marketing. Also, in Australia, Caltex formed a joint venture with the Australian petroleum company Ampol Limited to form the country's largest oil company, with over 2,000 retail outlets and refinery capacity of 185,000 barrels per day. 


\section{Figure 18. U.S. Refining Pollution Abatement Costs as a Share of Costs and Expenditures for the FRS Companies, 1977-1994}

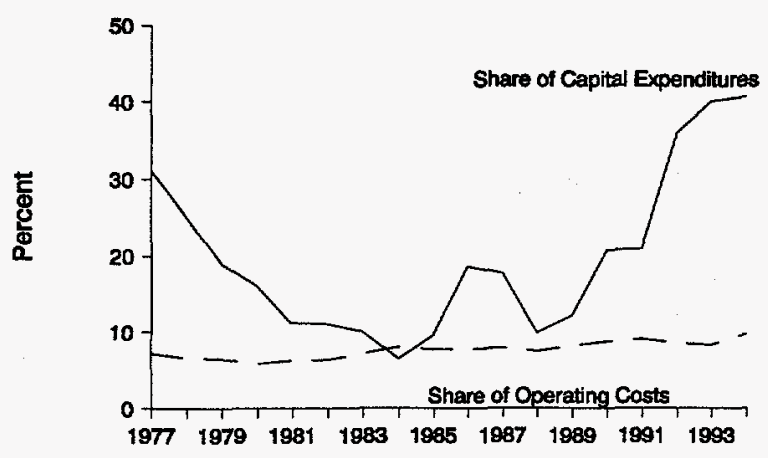

Source: U.S. Department of Commerce, Bureau of the Census, Current Industrial Reports, Pollution Abatement Costs and Expenditures (various issues) (Washington, DC).

For the last two decades, the capital intensity of FRS refining operations has grown considerably (Figure 19). ${ }^{57}$ Capital expenditures for pollution abatement accounted for a large portion of this growth. For 1994, the most recent year for which data are available, capital expenditures allocated to pollution abatement accounted for roughly 41 percent of total capital expenditures for U.S. refining, down slightly from the year-ago level. ${ }^{58}$ Environmentally-related capital expenditures also fell in 1993. As environmental capital expenditures have leveled off, so has the capital intensity of refining.

Another factor contributing to capital expenditures for U.S. refining has been a deterioration in the quality of crude oil inputs. However, over the last few years there also appears to be some attenuation of this trend. Since the late 1970's, refinery investment has been directed toward utilization of lower quality of crude oil inputs (i.e., lower gravity, higher sulfur content). The substantial investments in conversion capacity made in recent years may have reduced the demand for higher grades of crude oil. The heaviness of crude oil, as measure by API gravity, has changed little over the last 4 years (Figure 20), while the sulfur content of crude has declined for the past three years (Figure 21). This is probably a contributing factor to
Figure 19. Net PP\&E per Unit of Refinery Capacity for the FRS Companies, 1974-1995

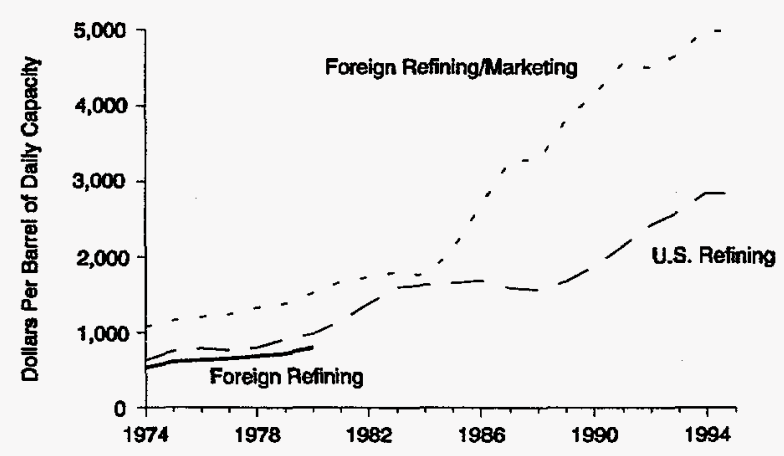

Note: Foreign refining data are not separately available from marketing data after 1980 .

Source: Energy Information Administration, Form EIA-28.

the decline in the price spread between high and low sulfur crude oil between 1993 and 1995. ${ }^{59}$

Two FRS companies consolidated their refining operations in 1995, selling $250,000 \mathrm{~b} / \mathrm{d}$ of refining capacity. Part of this loss reflected Kerr-McGee's complete withdrawal from U.S. refining and the sale of its three refineries to independent refiners. In 1995, Chevron sold its 185,000 b/d Port Arthur refinery to Canadian-based Horsham, thereby further increasing the role of foreign investors in U.S. refining. In 1994, foreign companies controlled 29 percent of U.S. refining capacity. (For a discussion on foreign investment trends in U.S. refining, see Chapter 6, and for a special discussion on Petroleos de Venezuela's expanding role in U.S. downstream, see the box entitled "Venezuela's Growing U.S. Petroleum Operations").

\section{U.S. Gasoline Marketing}

The 1990's have been marked by little increase in U.S. gasoline consumption, ${ }^{60}$ a development which has resulted in a sluggish market for motor gasoline and petroleum products, and encouraged gasoline marketers to reduce operating costs. The sluggish market has also

\footnotetext{
${ }^{57}$ Capital intensity is the ratio of crude oil throughput over net investment in place.

${ }^{58}$ U.S. Department of Commerce, Bureau of the Census, Current Industrial Reports, Pollution Abatement Costs and Expenditures, MA200(94)-1 (Washington, DC, May 1996), p. 10.

${ }^{59}$ Petroleum Marketing Intelligence, various issues, 1993 through 1996.

${ }^{60}$ Motor gasoline supplied increased 2 percent between 1994 and 1995. See Energy Information Administration, Monthly Energy Review, DOE/EIA-0035(96/08) (Washington, DC, August 1996), Table 15.
} 
Figure 20. Gravity of Crude Oil Inputs to U.S. Refineries, 1981-1995

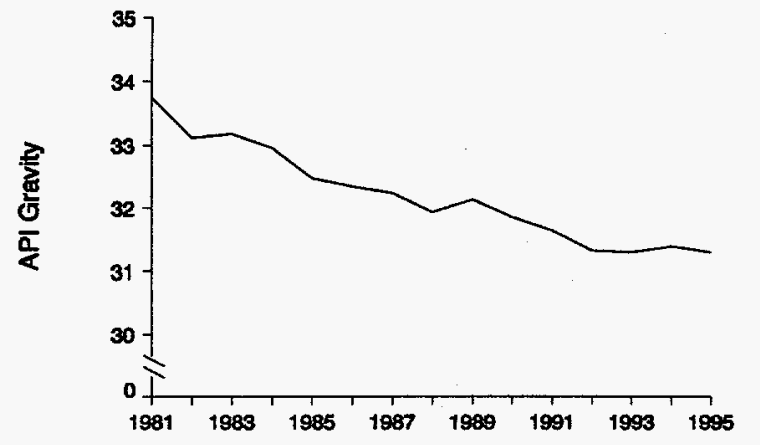

Source: Energy Information Administration, Petroleum Supply Annual, Volume 1, DOE/EIA-0340 (Washington, DC), Table 16 of various issues.

created an incentive for gasoline marketers to increase the value yielded by their gasoline station assets by using a variety of marketing innovations.

The FRS companies have been consolidating their marketing operations along geographical lines over several years. In particular, the average number of States (including the District of Columbia) in which FRS companies operate fell from 32 in 1984 to 22 in $1995 .^{61}$ The most dramatic consolidations, however, occurred earlier in the decade. The average number of States in which the FRS companies have marketing operations fell only from 23 to 22 between 1994 and $1995,{ }^{62}$ indicating that FRS retrenchment of marketing operations largely has concluded. Concurrent with the consolidation of operations is an increased reliance on sales through jobbers / wholesalers $^{63}$ and direct sales to fleets and other commercial and industrial customers-another way in which the FRS companies have tried to reduce their costs.

One of the results of the reduced scope of FRS gasoline marketing operations is that the FRS companies reduced the number of their branded outlets for the seventh year in a row. ${ }^{64}$ The 5-percent reduction in FRS branded outlets between 1994 and 1995 was led by a 6-percent reduction in dealer-operated outlets (Table 23). The total retail volume of gasoline sold by FRS companies fell 5 percent,
Figure 21. Average Sulfur Content of Crude Oil Inputs to U.S. Refineries, 1981-1995

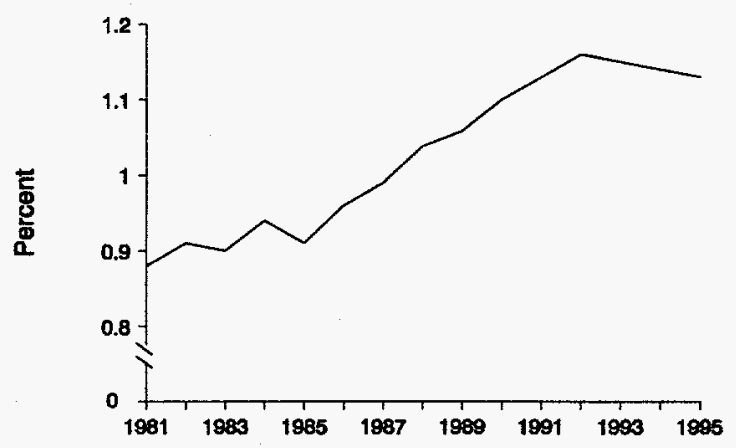

Source: Energy Information Administration, Petroleum Supply Annual, Volume 1, DOE/EIA-0340 (Washington, DC), Table 16 of various issues.

but, given the slightly larger reduction in the number of outlets, there was hardly any change in average outlet volume.

Recent efforts to reduce costs appeared successful in 1995, as marketing costs per barrel of product sold fell 6 percent from 1994 costs (Table 24). The FRS companies have reduced their marketing costs by nearly a dollar per barrel of product (after adjusting for inflation) since 1991. The results across FRS companies, however, were mixed. The 12 largest companies reduced their marketing costs during 1995, led by the medium-sized companies' 11-percent reduction, while the smallest companies' costs increased 17 percent. Nevertheless, the smaller FRS companies still registered substantially lower marketing costs than the larger companies. Reduced marketing costs, however, were insufficient to generate higher refined product margins, which fell 31 percent. Only the medium-sized FRS companies were able to both reduce marketing costs and gain higher refined product margins.

\section{Convenience Stores and Marketing Innovations Add Value}

Tied to restructuring and cost-cutting is a change in the format of FRS gasoline outlets. The FRS companies are closing some outlets, but others are being replaced by

\footnotetext{
${ }^{61}$ National Petroleum News 1985 Fact Book, Vol. 75 (mid-June 1985), p. 35; and National Petroleum Market Facts '96, Vol. 86, No. 8 (mid-July 1996), pp. 35-41.

${ }^{62}$ National Petroleum News Market Facts '95, Vol. 85, No. 7 (mid-June 1995), pp. 35-43; and National Petroleum Market Facts '96, Vol. 86, No. 8 (mid-July 1996), pp. 35-41.

${ }^{63}$ Between 1992 and 1995, jobbers/wholesalers' sales increased 15 percent and their share of retail sales increased 4 percent . See Energy Information Administration, Form EIA-28, Financial Reporting System.

${ }^{64}$ Total branded outlets of FRS companies fell from approximately 179,000 in 1977 to about 38,000 in 1995 . See Energy Information Administration, Form EIA-28, Financial Reporting System.
} 


\section{Venezuela's Growing U.S. Petroleum Operations}

Since first entering the U.S. refined product market in 1986, Venezuela's state petroleum company, Petroleos de Venezuela, S.A. (PDVSA) has increased its asset base in the United States to over $\$ 6$ billion. Through its U.S. subsidiaries, PDVSA accounts for roughly 5 percent of U.S. refinery capacity and 7 percent of U.S. retail gasoline outlets. In 1995, PDV America, PDVSA's U.S. affiliate, was the sixth largest U.S. petroleum refiner and the second largest foreign-held refiner after Shell Oil Company.

PDVSA's U.S. operations consist of one wholly-owned subsidiary (CITGO), and two affiliates (UNO-VEN, and LyondellCITGO). The UNO-VEN Company is a 50/50 joint venture between PDV America and Unocal. CITGO also carries a ten-percent interest in a 265,000 barrels per day (b/d) refinery jointly held with the ARCO subsidiary, Lyondell.

CITGO owns and operates four refineries in the United States with a total distillation capacity of $503,000 \mathrm{~b} / \mathrm{d}$ and markets gasoline and lubricants through more than 13,000 U.S. outlets-the largest number of branded gasoline stations served by an individual company in the country. UNO-VEN, a downstream joint venture created in 1989 by PDVSA and Unocal, ${ }^{a}$ refines petroleum products in one jointly-owned refinery and markets gasoline and other products to consumers. UNO-VEN supplies approximately $2,700^{b}$ " $76^{\prime \prime}$ branded outlets in sixteen states, chiefly in the Midwest. ${ }^{d}$

Neither CITGO nor UNO-VEN owns any crude oil reserves. Instead, both rely on crude oil purchases to supply their refineries. CITGO has long-term contracts with PDVSA and one-year renewable contracts with Petroleos Mexicanos (PEMEX), the state-oil company of Mexico, both of which produce heavy, sour crude oil. The contract with PDVSA serves as an outlet for Venezuelan crude oils.

PDVSA gained entry into the U.S. petroleum industry when it purchased half of CITGO in 1986 from the Southland Corporation for $\$ 400$ million; the remainder of CITGO was purchased in 1990 for $\$ 675$ million. At the time, CITGO operated one petroleum refinery in Lake Charles, Louisiana. In 1987, PDVSA obtained a 50-percent interest in Champlin Petroleum's Corpus Christi Refinery for $\$ 93$ million. Champlin and CITGO were later merged. The Paulsboro, New Jersey, refinery was purchased from Seaview Corp. in 1991 and the Savannah, Georgia, refinery was purchased from Amoco Oil in 1993. Currently, CITGO's refineries are located in Lake Charles, Louisiana $(305,000$ b/d); Corpus Christi, Texas (130,000 b/d); Paulsboro, New Jersey (40,000 b/d); and Savannah, Georgia (28,000 b/d). In 1989, PDV America entered into a joint venture with Unocal Corporation involving Unocal's transferring 50-percent ownership of its Lemont, llinois, refinery $(147,000 \mathrm{~b} / \mathrm{d})$ to the Uno-Ven joint venture. The value of this latter transaction was placed at $\$ 500$ million. In 1993, CITGO purchased a 10-percent share in a Houston, Texas, refinery from Lyondell Petrochemical and in 1995 CITGO purchased Cato Oil \& Grease Company, a manufacturer and distributor of lubricants, from Kerr-McGee for $\$ 47$ million. $^{\circledR}$

Unlike most of the FRS companies, PDV America has expanded its marketing operations in the 1990's, adding approximately 900 stations to its CITGO-branded network during $1995 .{ }^{\dagger}$ The additional branded outlets contributed to CITGO's 14-percent increase in gasoline sales volume during 1995, relative to 1994 sales.

\footnotetext{
aRhodes, Anne and A.D. Koen, "U.S. Refiners Find Benefits in JVs with Foreign Partners," Oil and Gas Journal (July 22, 1996), p. 16ff. buUNO-VEN Expands Retail," Platts Oilgram News, Vol. 74, No. 48 (March 8, 1996), p. 3.

'PDV America, Inc., 1995 Form 10-K, p. 16.

${ }^{d}$ National Petroleum News, Market Facts '95, Vol. 87, No. 7 (mid-June 1995), pp. 35-46.

${ }^{\circ}$ PDV America, Inc., 1995 Form 10-K, Deloitte and Touche, LLP, Independent Auditor's Report, p. 11.

'PDV America, Inc., 1995 Form 10-K, p. 25.
} 


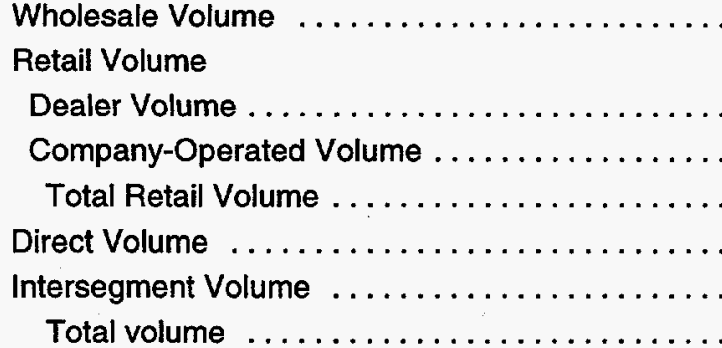

Dealer Outlets

Total Retail Outlets $\ldots \ldots \ldots \ldots \ldots$

Average Monthly Outlet Volume

Dealers . . . . . . . . . . . . . . . . .

Company Operated $\ldots \ldots \ldots \ldots \ldots \ldots \ldots$

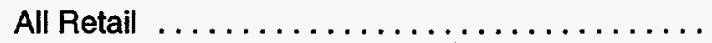

$\begin{array}{rrr}1,064.3 & 1,117.3 & 5.0 \\ 736.4 & 680.3 & -7.6 \\ 308.3 & 309.4 & 0.4 \\ 1,044.7 & 989.8 & -5.3 \\ 228.6 & 303.5 & 32.8 \\ 9.2 & 11.4 & 24.1 \\ 2,346.8 & 2,422.0 & 3.2\end{array}$

(number of outlets)

$\begin{array}{rrr}31,705 & 29,811 & -6.0 \\ 8,755 & 8,549 & -2.4 \\ 40,460 & 38,360 & -5.2\end{array}$

(thousand gallons per month)

$\begin{array}{lll}81.3 & 79.9 & -1.7\end{array}$

$123.3 \quad 126.7 \quad 2.8$

$\begin{array}{lll}90.4 & 90.3 & -0.1\end{array}$

Note: Percent changes were calculated from unrounded data.

Source: Energy Information Administration, Form ElA-28.

Table 24. Marketing Characteristics and Refined Product Margin for FRS Companies Ranked by Total Energy Assets, 1994-1995

\begin{tabular}{|c|c|c|c|c|c|c|}
\hline \multirow[b]{2}{*}{ Group } & \multicolumn{2}{|c|}{$\begin{array}{c}\text { Average Outlet Volume } \\
\text { (thousand gallons } \\
\text { per month) }\end{array}$} & \multicolumn{2}{|c|}{$\begin{array}{c}\text { Refined Product Margin } \\
\text { Per Barrel } \\
\text { (dollars per barrel) }\end{array}$} & \multicolumn{2}{|c|}{$\begin{array}{c}\text { Marketing Expenses } \\
\text { Per Barrel } \\
\text { (dollars per barrel) }\end{array}$} \\
\hline & 1994 & 1995 & 1994 & 1995 & 1994 & 1995 \\
\hline Top Four & 90.6 & 84.0 & 0.77 & 0.40 & 1.85 & 1.84 \\
\hline Five Through Twelve ...... & 119.8 & 122.7 & 0.54 & 0.70 & 2.23 & 1.99 \\
\hline All Other & 60.6 & 61.2 & 0.82 & 0.29 & 1.11 & 1.30 \\
\hline All FRS $\ldots \ldots \ldots \ldots \ldots$ & 90.4 & 90.3 & 0.71 & 0.49 & 1.80 & 1.75 \\
\hline
\end{tabular}

Source: Energy Information Administration, Form EIA-28.

high-volume stations, many of which are tied to a convenience-store format. Although convenience stores are associated with higher sales volumes of motor gasoline, and, by implication, higher profitability, the number of convenience stores associated with FRS gasoline outlets has changed little during the 1990's and was slightly more than 12,000 in 1995 , according to the National Petroleum News. ${ }^{65}$ However, the percentage of FRS gasoline outlets that also are convenience stores has grown in recent years, increasing from 27 percent in 1992

\footnotetext{
${ }^{65}$ Smith, Don, "The Industry Rebounds," National Petroleum News, Vol. 85, No. 9 (August 1993), pp. 8-20; "Abundancia: The Rebound Continues," National Petroleum News, Vol. 86, No. 11 (October 1994), pp. 14-33; and "Survey Underscores Co-branding Growth, Accelerated Store Upgrade Investments," National Petroleum News, Vol. 87, No. 11 (October 1995), pp. S8-S12, S15-S28, and S31.
} 
to 32 percent in $1995 .{ }^{66}$ The growing share implies that convenience store gasoline stations may be more profitable than traditionally-formatted stations, although this implication must be tested more thoroughly before it can be given much credence. ${ }^{67}$

Even though the profitability of convenience store operations is not directly observed, revenue generated from non-gasoline sales through company-operated outlets on a per-outlet basis may be an approximate indication of added value. The FRS companies' revenue from convenience store gasoline outlets (as measured by "other refining and marketing revenue" divided by company-owned outlets) ${ }^{68}$ increased 39 percent during the 1990 's. ${ }^{69}$ Despite the limitations of the data, there seems to be a strong implication that FRS company gasoline stations associated with convenience store operations are relatively profitable.

Marketers' costs are reduced and the value of their operations are increased with the addition of card readers (typically a pump card reader that serves a single pump, but sometimes an island card reader that serves multiple pumps) ${ }_{1}^{70}$ which reduce the amount of time required to conduct a transaction, and effectively lower consumers' costs of acquiring motor gasoline. Shorter transactions can allow an outlet to service a larger number of customers during a given period of time and possibly attract additional customers, particularly those in a hurry. According to their financial disclosures, most FRS companies have begun installing card reader pumps, ${ }^{71}$ or plan to do so during 1996. ${ }^{72}$ The exception is ARCO, which is testing an automated pay station on the pump islands that will accept either cash or credit/debit cards. ${ }^{73}$

A development that began as long ago as $1987,,^{74}$ but is still being implemented, is the multiple format station. The multiple format station is the next logical step as one moves beyond the traditional convenience store operation. Convenience stores have offered fast food for years, but many multiple format stations sell nationally-known name-brand fast food in addition to gasoline. Multiple format stations provide an opportunity to share the capital costs of a retail outlet with a tenant (in which case, space in the outlet is leased to the operator(s) of the other business(es)), or provides a highly-recognizable product that will attract additional customers to the multiple format station. Although many FRS companies introduced multiple format stations during $1994,{ }^{75}$ about half the 1995 respondents with marketing operations indicated that they opened during 1995, or will open during 1996, multiple format stations, including ARCO, Ashland, Chevron, Exxon, Phillips, Sun, Texaco, Unocal, and USX/Marathon. ${ }^{76}$

${ }^{66}$ Lindenberg, Greg and Don Smith, "C-store/Gasoline Outlets: A State by State Tally," National Petroleum News, Vol. 85, No. 1 (January 1993), pp. 41-56; and "Survey Underscores Co-branding Growth Accelerated Store Upgrade Investments," National Petroleum News, Vol. 87 , No. 11 (October 1995), pp. S8-S12, S15-S28, and S31.

${ }^{67}$ Two factors undermine the conclusion of profitability from this information. First, only 3 of the 17 FRS companies included in the convenience store survey supplied company- or direct- operated outlet numbers; Amoco, BP America, and Unocal. The remaining companies may also have included lessee outlets, over which the FRS companies only have limited control. Second, the survey is purely voluntary, leaving the responding companies with small incentive to ensure the accuracy of the information they provide.

${ }^{68}$ Non-gasoline convenience store revenues are not directly collected from the FRS companies, but revenue from non-gasoline sales is collected. The category "other refining and marketing revenue" was originally intended to measure revenue from sales of tires, batteries, and accessories at traditional gasoline stations. It now tends to capture convenience store non-gasoline sales revenue with an occasional unusual item (e.g., a favorable legal judgement) included. Although not all company-operated retail outlets are convenience store formats, many are. Thus, despite the failings of the data, the findings provide insight into the general profitability of FRS convenience store operations.

${ }^{69}$ Energy Information Administration, Form EIA-28, Financial Reporting System

${ }^{70}$ Abcede, Angel, "Pay-at-the-Pump: How Far, How Fast?" National Petroleum News, Vol. 85, No. 5 (May 1993), p. 52.

${ }^{71}$ The companies who indicated they had installed card reader pumps during 1995 included Chevron, which has now converted 83 percent of its company-operated and lessee outlets, Fina, Sun, and Unocal. See Chevron Corporation, 1995 Annual Report, p. 18; Fina, 1995 Annual Report, p. 16; Sun Company, 1995 Annual Report, p. 10; and Unocal Corporation, 1995 Annual Report, p. 16.

${ }_{72}$ Amerada Hess indicated that it plans to begin installing card reader pumps during 1996. See Amerada Hess Corporation, 1995 Annual Report, p. 18.

${ }^{73}$ ARCO, 1995 Annual Report, p. 13

${ }^{74}$ Booth, Michael, and Kate Bulkley, "Amoco Offers Sites to Fast-Food Chains," The Denver Business Journal, Vol. 39, No. 2 (October 5, 1987), p. 1.

${ }^{75}$ Companies noting the introduction of multiple format stations, or considering such stations, in their 1994 financial disclosures included: Amoco, Ashland, Chevron, Exxon, Texaco, Unocal, and USXIMarathon. See Energy Information Administration, Performance Profiles of Major Energy Producers 1994, DOE/EIA-0206(94) (Washington, DC, February 1996), p. 42.

${ }^{76}$ ARCO, 1995 Annual Report, p. 14; Ashland Incorporated, 1995 Annual Report, p. 26; Chevron Corporation, 1995 Annual Report, p. 5; Exxon Corporation, 1995 Annual Report, pp. 14-17; Phillips Petroleum Company, 1995 Annual Report, p. 16; Sun Company, 1995 Annual Report, p. 10 ; Texaco Corporation, 1995 Annual Report, pp. 17-19; Unocal Corporation, 1995 Annual Report, p. 16; and USX Corporation, 1995 Security and Exchange Commission Form 10-K, p. 19. 


\section{Foreign Refining and Marketing}

Although the FRS companies' foreign refining and marketing operations benefitted from higher overseas sales volumes, higher refinery utilization rates, and lower tax rates, lower overseas refining margins in 1995 restrained income growth. Margins were lower both in Asia and in Europe, although the decline in margins from 1994 in Europe was more pronounced (Figure 22). On balance, net income from foreign refining/marketing (excluding unusual items) was down slightly (Table 21).

\section{Figure 22. Foreign Refining Margins, 1993-1995}

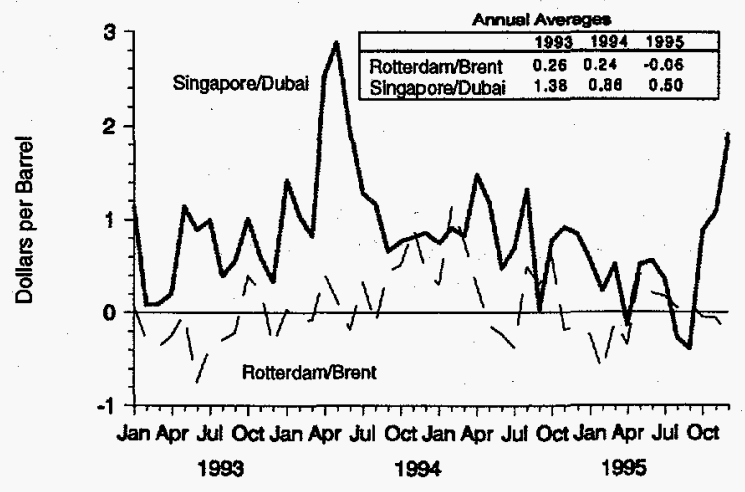

Note: Refining margin is defined as netback crude oil price less spot crude oil price. Netback price is calculated by multiplying the spot price of each refined product by its percentage share in the yield of a barrel of crude oil. Transport and out-of-pocket refining costs are then subtracted to arrive at netback price.

Source: Petroleum Market intelligence, September 6, 1991, p. 8; April 2, 1992, p. 8; January 7, 1993, p. 8; January 6, 1994, p. 8: and January 5,1995, p. 8.

\section{FRS Companies' Investment Focused on Emerging Markets}

Overseas refining/marketing has generally been a growing area of investment for the FRS companies since the early 1990's. Much of this growth in foreign investment has been directed to Asia rather than to Europe, where economic growth rates have been significantly less and where refined product markets are more mature (see the box entitled "Recent FRS Downstream Investment Activities in the Pacific Rim, Latin America, and Eastern Europe"). In recent years, refined product demand growth in Asia has far exceeded growth in North America and Europe (Figure 23). In 1995, the FRS companies owned roughly 2,700 thousand barrels per day in European refinery capacity and roughly 2,200 thousand barrels per day in Asia, including proportional shares in unconsolidated affiliates.

\section{Figure 23. World Petroleum Consumption by Region, 1990 and 1995}

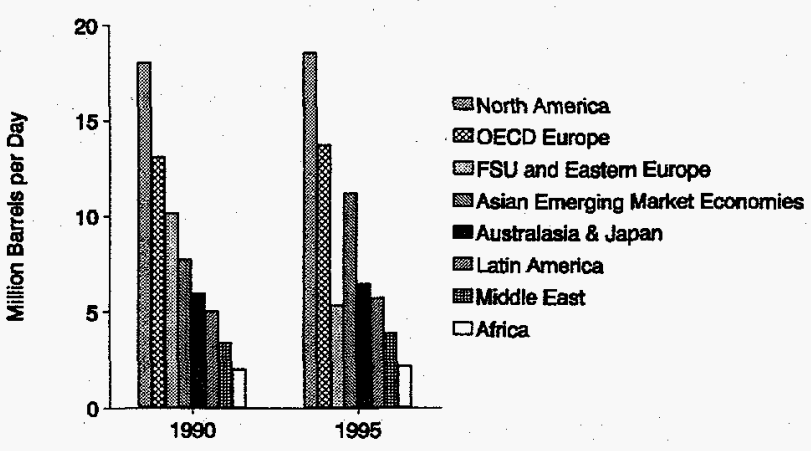

Source: British Petroleum Company, p.I.c., BP Statistical Review of World Energy (London, June 1995).

In Western Europe, the FRS companies operate in a market that has been declining for several years. Further, little in the way of refinery expansion is expected to take place in Western Europe in the near future, as Western European refinery capacity has fallen in every year since $1991 .{ }^{77}$ The growing integration of Western and Eastern Europe could also result in some additional downstream consolidation. As a consequence, the FRS companies have been reducing the scale of their Western European operations for several years. In 1995, Mobil closed its Woerth refinery in Germany. The FRS companies also scaled back their Canadian downstream operations in 1995. Sun sold Suncor and in the process divested its 70,000 barrels per day Canadian refinery, while Exxon's Canadian subsidiary, Imperial, closed a 44,000 barrels per day refinery in Vancouver, Canada.

Efforts by FRS companies to reduce operating costs through consolidation and restructuring are occurring in Western Europe ${ }^{78}$ and other mature foreign markets. A notable example of this restructuring is BP and Mobil's recently-announced marketing joint venture (see the box

\footnotetext{
${ }^{n}$ British Petroleum Company p.l.c., BP Statistical Review of World Energy (1996), p. 16.

${ }^{78}$ For example, BP sold parts of retail networks in Portugal and France and Mobil sold retail outlets in Switzerland. See British Petroleum Company p.l.c., Annual Report on Form 20-F 1995, p. 18; and Mobil Corporation, 1995 Annual Report, pp. 9-11.
} 


\section{Recent FRS Downstream Investment Activities in the Pacific Rim, Latin America, and Eastern Europe}

In their 1995 public releases, the FRS companies announced several investment commitments to the growing markets of Asia, Latin America, and Eastern Europe. For the FRS companies' foreign operations, these regions represent significant growth markets, in contrast to the more mature markets of North America and Western Europe. Some recently announced overseas downstream investments obtained from excerpts in company annual reports include the following:

- Amoco plans to open 10 to 15 gasoline service stations in Poland, Romania, and Bulgaria by the end of 1996 . $^{a}$ Amoco entered a joint venture with Oxxo, Mexico's largest convenience store chain. In China, Amoco established a joint venture to build and operate a liquefied petroleum gas terminal and is evaluating other refining and marketing joint ventures. In Russia, Amoco opened the first U.S. service station outside of Moscow.

- Caltex, which is a joint venture of Chevron and Texaco, plans an increased focus on the Pacific Rim and entry into emerging markets, such as Central and Latin America, China, India, Vietnam, Sri Lanka, and Cambodia. ${ }^{b}$ Caltex is currently engaged in marketing activities in southern China and plans to expand into other areas. Caltex plans to spend $\$ 4.4$ billion on refining/marketing projects in South Korea and to expand its capacity at its Yocheon, Korea, refinery to 600,000 barrels per day, making it one of the world's largest refineries. In the Philippines, Caltex plans to construct over 200 new service stations in addition to the 900 retail outlets it currently serves. Caltex is also engaged in an instrument modernization project at its 71,000 barrels-per-day Batangas, Philippines, refinery. In Singapore, Caltex plans to acquire new service stations and refurbish existing stations. In Australia, Caltex merged with Ampol Limited to form the country's largest oil company, with over 2,000 retail outlets and refinery capacity of 185,000 barrels per day.

- DuPont's Conoco acquired an interest in two refineries in the Czech Republic. ${ }^{c}$ Conoco recently began construction of a 100,000-barrels-per-day refinery in Malaysia. Conoco expanded its retail network in Thailand and is conducting a study on a possible participation in a new refinery in Vietnam.

- Exxon reported that the Asia-Pacific region is the company's fastest growing market, with Exxon's sales increasing at 4 percent annually over the last 5 years. ${ }^{d}$ Exxon has recently expanded its retail gasoline networks in eastern Germany, Hungary, Poland, Czech Republic, and Slovakia. Exxon undertook major expansions in Thailand, Malaysia, Singapore, and Japan and established a lubricants market presence in Vietnam, China, and India. Exxon also plans an upgrade of its Capana refinery in Argentina.

- Mobil is currently constructing two lubricants manufacturing plants in China and is expanding its lubricants business in Argentina and Venezuela. ${ }^{e}$ Mobil is also expanding its retail gasoline network in Ecuador and Peru and convenience store network in Mexico.

- Texaco reported a 9-percent refined product sales volume increase for Latin America in $1995 .^{f}$ Texaco completed an upgrade of its Panama refinery to increase production capacity to 60,000 barrels per day.

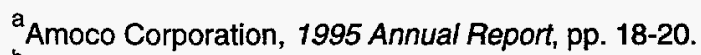

${ }^{b}$ Chevron Corporation, Supplement to the Chevron Corporation 1995 Annual Report, p. 38.

'DuPont Corporation, 1995 Annual Report, pp. 14-15.

'Exxon Corporation, 1995 Financial and Operating Review, pp. 52-57.

EMobil Corporation, Mobil Fact Book 1995, pp. 55-56.

'Texaco Corporation, Annual Report 1995, p. 20.
} 
entitled "A New Wave of Joint Ventures" on page 39). By contrast, developing Asian countries, along with the countries of Latin America, Eastern Europe, and the Former Soviet Union, are targets of expansion by the FRS companies. Amerada Hess, Amoco, Coastal, DuPont/ Conoco, Exxon, and Mobil all announced ventures, or intended ventures, in one or more of these areas. In addition, many of the same recent advances introduced into U.S. gasoline retailing are slated for these new marketing targets: multiple format stations, ${ }^{79}$ expansion of convenience store operations, and upgrading and renovating traditional gasoline stations. ${ }^{80}$

\section{Transportation}

\section{Natural Gas Pipeline Income Up Despite the Effects of Order 636}

The year 1995 marked the second full year the interstate natural gas pipeline industry operated under Federal Energy Regulatory Commission (FERC) Order 636. Order 636 was issued in April, 1992, and required pipelines to "unbundle" natural gas transportation services by offering transportation, sales, and storage services separately. ${ }^{81}$

Prior to Order 636, pipeline companies could offer services, such as gas sales, transportation, and storage, "bundled" or grouped together for a single contract price. However, under this Order, interstate pipelines now provide only gas transportation and storage services, both of which are separately priced. The sale of natural gas to local distribution companies and end-users is now being conducted by producers and nonregulated marketing companies, including interstate pipeline company affiliates. In addition, the Order established a secondary market for released capacity. The capacity release program allows customers to sell their excess firm gas transportation capacity ${ }^{82}$ on a temporary basis, or relinquish their firm capacity when those contracts expire. ${ }^{83}$ With pipeline open access, wellhead deregulation, and restructuring, natural gas pipeline operations of the FRS companies continued to face increased competition in 1995.

In 1995, revenue of the FRS natural gas pipelines declined 6 percent, due almost entirely to lower transportation revenues (Table 25). Although natural gas transportation volumes increased for the FRS majors, ${ }^{84}$ the companies saw diminished prices as a result of excess pipeline capacity and natural gas supplies, and market distortions caused by an underpriced secondary market for pipeline capacity. ${ }^{85}$ Diminished prices were especially prevalent in the midwestern region, where the market is saturated with plentiful supplies of natural gas from Canadian imports. The majority of the FRS companies' pipeline operations are in California and midwestern areas. ${ }^{86}$ Also, Enron stated that revenue fell by $\$ 114$ million compared to revenue in 1994 due primarily to the completion of the "recovery of certain transition costs" ${ }^{87}$ (related to the termination of their merchant role due to Order 636). However, total FRS company income from natural gas pipelines (excluding unusual items) was up 19 percent (Table 25), as operating expenses fell in 1995 due primarily to the reduction in transmission costs attributed to the cessation of volumes transported for sale and system modernization. ${ }^{88}$

Overall, capital expenditures declined 14 percent between 1994 and 1995 (Table 25). However, Occidental reported an increase in expenditures of $\$ 57$ million due to two pipeline lateral extensions in Illinois and Arkansas, plus a 15-mile pipeline extension in the Gulf of Mexico. ${ }^{89}$ Other projects included:

Enron. In 1995, Enron's subsidiary, Northern Border Pipeline, and partners, sought FERC approval for the expansion of Northern Border's main line from the Canadian border to Harper, Iowa. In addition, the

${ }^{79}$ Exxon Corporation, 1995 Annual Report, p. 17.

${ }^{80}$ Exxon Corporation, 1995 Annual Report, p. 15

${ }^{81}$ FERC Order Number 636, p. 31.

${ }^{82}$ Firm gas is defined as gas sold on a continuous basis and is generally on a long-term contract. Conversely, interruptible gas is gas sold to customers with a provision that permits the curtailment or cessation of service at the discretion of the distributing company. Source: Energy Information Administration, Glossary of Energy and Energy-Related Terms and Definition, Second Edition, DOE/EIA-0537(95)(Washington DC, May 1995), pp. 58 and 80.

83."Beyond 2000: A Pipeline Odyssey," Oil and Gas Investor (June 1996), pp. 36-41.

${ }^{84}$ Enron Corporation, 1995 Annual Report, p. 38; Coastal Corporation, 1995 Annual Report, p. 36; and Occidental Corporation, 1995 Annual Report, p. 22.

${ }^{85}$ Coastal Corporation, 1995 Annual Report, p. 36.

${ }^{86}$ One of Coastal's two pipelines, ANR, operates in the Midwestern markets. The other pipeline, Colorado International Gas operates in the Rocky Mountain area. Three of Enron's four interstate pipelines and affiliates, Transwestern Pipeline, Northern Natural Pipeline, and Northern Border pipeline operate in the saturated areas of California and in the Midwest area. Enron' other pipeline, Transwestern operates in the Florida peninsular and is the only pipeline that services this area. Occidental's subsidiary, MidCon, owns Natural Gas Pipeline Company (NGPC). The NGPC operates in the Midwest area

${ }^{87}$ Enron Corporation, 1995 Annual Report, p. 38.

${ }^{88}$ Enron Corporation, 1995 Annual Report, p. 38

${ }^{89}$ Occidental Corporation, 1995 Annual Report, p. 23. 
Table 25. Financial Items for Transportation for FRS Companies, 1994-1995 (Million Dollars)

\begin{tabular}{|c|c|c|c|}
\hline Financial Items & 1994 & 1995 & $\begin{array}{c}\text { Percent Change } \\
1994-1995 \\
\end{array}$ \\
\hline \multicolumn{4}{|l|}{ Natural Gas Pipelines ${ }^{a}$} \\
\hline Revenues... & 5,643 & 5,322 & -5.7 \\
\hline Operating Expenses ${ }^{b}$ & 4,949 & 4,495 & -9.2 \\
\hline Operating Income ${ }^{b}$.. & 694 & 827 & 19.2 \\
\hline Additions to Investment in Place ${ }^{c}$ & 495 & 425 & -14.1 \\
\hline \multicolumn{4}{|l|}{ Liquids Pipelines $^{d}$} \\
\hline Revenues. & 4,650 & 4,535 & -2.5 \\
\hline Operating Expenses ${ }^{\mathrm{b}}$ & 2,969 & 2,445 & -17.6 \\
\hline Operating Income ${ }^{b}$ & 1,681 & 2,090 & 24.3 \\
\hline Additions to Investment in Place ${ }^{\mathrm{C}}$. & 324 & 557 & 71.9 \\
\hline \multicolumn{4}{|l|}{ International Marine } \\
\hline Revenues........ & 2,337 & 2,150 & -8.0 \\
\hline Operating Expenses & 2,408 & 2,182 & -9.4 \\
\hline Operating Income $\mathrm{C}^{\mathrm{b}}$. & -71 & -32 & -- \\
\hline Additions to Investment in Place ${ }^{\mathrm{C}}$. & 251 & 276 & 10.1 \\
\hline
\end{tabular}

${ }^{2}$ Data are for FRS companies with pipeline assets primarily in natural gas transmission.

${ }^{b}$ Excludes unusual items.

'Measured by additions to property, plant, and equipment, plus additions to investments and advances of all FRS companies.

${ }^{d}$ Data are for FRS companies with pipeline assets primarily in liquids pipelines.

-- = Not meaningful.

Source: Energy Information Administration, Form EIA-28.

company plans to build a pipeline from Harper, Iowa, to a point near Manhattan, Illinois. The $\$ 800$-million project will supply new gas from Canada and will provide additional gas to the midwestern market. ${ }^{90}$

Occidental. Occidental's subsidiary, MidCon, owns Natural Gas Pipeline Company of America (NGPC). The NGPC filed a proposal similar to Enron's to expand its operations and its existing system in the Midwest from Harper, Iowa, to Chicago, Illinois. The new facilities will accommodate an additional 500,000 cubic feet per day (cfp/d) of new natural gas supplies, almost doubling NGPC existing capacity of Canadian gas to 900,000 $\mathrm{cfp} / \mathrm{d} .^{91}$

Coastal. Both of Coastal's pipelines are pursuing growth opportunities. Wyoming Interstate Company is expanding a segment of the 800-mile Trailblazer Pipeline System to the eastern region and the other pipeline, ANR, will build a pipeline to connect its system to markets in Canada. $^{92}$

\section{Crude Oil Pipeline Income Increases Due to Lower Operating Expenses}

The FRS companies involved in liquids pipelines realized a 24-percent gain in pipeline income as lower operating expenses more than offset a decline in revenues (Table 25).

Developments in the Trans Alaskan Pipeline (TAPS) are central to the financial performance of the FRS companies' liquids pipelines. TAPS transports crude oil and natural gas liquids (NGLs) from the Alaskan North Slope (ANS) to the port of Valdez, Alaska, making ANS crude oil accessible to other areas of the United States. In 1995, seven of the FRS companies jointly owned the pipeline. ${ }^{93}$ Prudhoe Bay is the largest oil field in the United States

\footnotetext{
${ }^{90}$ Enron Corporation, 1995 Annual Report, p. 38.

${ }^{91}$ Occidental Corporation, 1995 Annual Report, pp. 14 and 15.

${ }^{92}$ Coastal Corporation, 1995 Annual Report, pp. 10 and 11.

${ }^{93}$ The following FRS companies together own 100 percent of the Trans Alaska Pipeline: Amerada Hess Corporation, Atlantic Richfield Corporation, BP Corporation, Exxon Corporation, Mobil Corporation, Phillips Petroleum Company, and Unocal Corporation. However, of these seven ARCO, BP Corporation and Exxon account for 92 percent of TAPS ownership. Source: Energy Alert (April 3, 1992).
} 
and accounts for the majority of TAPS throughput. Other producing areas in the ANS are Kuparuk River, Milne Point, Endicott, Point McIntyre, Niakuk, and Lisburne fields. ${ }^{94}$ The TAPS throughput in 1995 was 1,523 barrels per day (b/d), compared to $1,587 \mathrm{~b} / \mathrm{d}$ in the previous year, reflecting the decline in ANS production..$^{95}$ (See the box entitled "The Survival of ANS Production.") Tariff rates rose to $\$ 3.71$ per barrel in 1995 from $\$ 3.33$ per barrel in $1994{ }^{96}$ contributing to TAPS revenue of $\$ 2.1$ billion in 1995. Apart from TAPS, liquids pipeline revenues were down about $\$ 0.4$ billion, reflecting a continuing decline in lower 48-onshore oil production.
Operating expenses (excluding unusual items) were reduced by 18 percent, yielding a strong increase in income, indicating some success in cost-cutting measures (Table 25). Operators of TAPS have learned how to survive by lowering operating expenses in various ways. For example, in 1995, operating expenses dropped partly due to the reduction in maintenance and repairs on the pipeline during the prior year. Between 1991 and 1995, production costs in Alaskan fields have decreased 30 percent per barrel of oil partly due to consolidation of field-wide support services and leasing. ${ }^{97}$ To further reduce operating cost, the TAPS operator, Alyeska

\section{The Survival of ANS Production}

Between 1990 and 1994, two massive gas handling system and reservoir stimulation programs (GHX-1 and GHX-2) were installed at Prudhoe Bay by the largest producers of Alaskan oil with the intent to sustain the field's natural decline rate and enhance oil production. The GHX-1 was completed in 1991 and was successful at maintaining production levels in 1990, and in 1991. However, in 1992 and in the following year production levels began to decline again. Subsequently, in 1993 and 1994, phases I and II of the GHX-2 system were completed; the overall impact was an increase in field productionof 8.9 billion cubic feet per day. Although field production increased in 1995, this was not sufficient to offset the field's natural decline rate of 8,000 barrels per day per year. ${ }^{a}$ The entire GHX-2 expansion cost $\$ 1.3$ billion. ${ }^{b}$

In 1995, the producers launched another large-scale enhanced oil recovery project, similar to the GHXs at Prudhoe Bay, in order to extend the productive life of its second largest oil field, Kuparuk. The NGLs produced at Prudhoe Bay were injected into existing wells in Kuparuk in order to recover additional barrels of oil and offset the natural field decline. With this project, oil field recovery is estimated to increase by an additional 1.2 billion barrels. ${ }^{c}$

In 1995, legislative measures were implemented to encourage additional investment in ANS crude oil production. The U.S. Department of Energy (DOE) approved a 5-year project to develop methods to economically recover heavy oil in the Schrader Bluff-Milne Point field on ANS (located 12 miles west of Prudhoe Bay). The participants in this government-sponsored Cooperative Research and Development Agreement (Crada) program are BP Exploration (Alaska), DOE, and BDM-Oklahoma, Inc. The total cost for the project is $\$ 10.6$ million. The field covers 32,000 acres, and contains more than 2 billion barrels of heavy oil. ${ }^{d}$ In addition, Alaskan legislators passed a regulation to prevent double taxation of NGLs that are used in large-scale enhanced oil recovery (Lseor) projects. Prior to this law, NGLs were taxed when they were produced from a field, and re-taxed again after they were re-produced from a field used for Lseor. Legislation was also passed to lower royalty rates for oil produced in marginal, high cost fields. ${ }^{*}$ The Alaskan Oil Export ban was lifted on November 24, 1995 allowing crude oil to be exported overseas. ${ }^{\dagger}$ The anticipated rise in wellhead prices will make the development of ANS oil fields more attractive.

\footnotetext{
${ }^{2}$ Atlantic Richfield Corporation, 1993 Annual Report, p. 7, and Atlantic Richfield Corporation, 1994 Annual Report, p. 13.

'British Petroleum Corporation, 1993 Annual Report on Form 20-F, p. 14, and Atlantic Richfield Corporation, 1993 Annual Report, p. 7.

'Atlantic Richfield Corporation, 1995 Annual Report, p. 9.

dastudy Centers on North Slope Heavy Oil," Oil and Gas Journal (March 4,1996), p. 42.

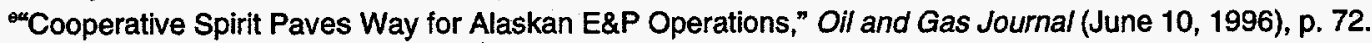

${ }^{\text {tu}}$ Clinton Lifts Ban on Alaskan Oil Export," Reuters World Service (April 28, 1996), p. 1.
}

\footnotetext{
${ }^{94}$ British Petroleum Company p.l.c., BP Financial and Operating Information, 1991-1995, p. 34.

${ }^{95}$ Energy Information Administration, Monthly Energy Review, DOE/EIA-0035(96/08) (Washington, DC, August 1996), Table 3.2a.

${ }^{96}$ ARCO Transportation Alaska, Inc., Historical Tariffs (September 27, 1996), p. 1.

${ }^{97}$ ARCO, 1995 Securities and Exchange Commission Form $10-K$, p. 8.
} 
Pipeline Service Company, placed 2 of the 10 TAPS pump stations on standby status on July 1,1996, reflecting the decline in ANS oil production. Using the 8 remaining stations, TAPS now has a capacity to transport 1.7 million $\mathrm{b} / \mathrm{d}$ of ANS production, $200,000 \mathrm{~b} / \mathrm{d}$ more than the projected ANS production. ${ }^{98}$

Capital expenditures for liquids pipelines increased 72 percent primarily due to initiatives of two FRS companies, ARCO and Shell (Table 25):

ARCO. In 1995, ARCO and Phillips Petroleum formed a joint venture to create a new crude oil pipeline system, Seaway Pipeline Company. This new pipeline will operate from the U.S. Gulf Coast to Cushing, Oklahoma, and will have an ultimate capacity to transport 800,000 $\mathrm{b} / \mathrm{d}$ - making it the second largest crude oil system in the Lower 48. Seaway combines ARCO's crude oil pipeline that operates between the Gulf of Mexico port at Texas City, Texas, and Cushing, Oklahoma, and Phillip's Seagas pipeline that stretches from Freeport, Texas, to Cushing, Oklahoma. Construction will begin in early $1996 .{ }^{99}$

Shell. Shell is pursuing a major growth opportunity in the Gulf of Mexico. The company is building two new pipelines to transport crude oil from the Green Canyon and Mississippi Canyon areas of the Gulf to onshore storage facilities. ${ }^{100}$

\section{International Marine Losses Reduced}

In 1995, the FRS companies operating in the international marine line of business reported an 8-percent decline in revenue compared to revenue in 1994 (Table 25). The decline in revenue was attributable mainly to the operations of Texaco, who sold its domestic and international marine operations in 1995. ${ }^{101}$ Excluding Texaco and the other companies who were operating in 1994 but did not report revenue in 1995, overall revenue increased 4 percent compared to 1994 revenue. For these same companies, net income was \$18 million in 1995 compared to losses of $\$ 23$ million in 1994. The financial performance of these companies benefitted from the recovery of freight rates in 1995 to an average of $\$ 1.14$ per barrel compared to $\$ 0.88$ in $1994 .{ }^{102}$ The rise in 1995 was due to increased crude oil transportation demand coupled with a decline in surplus tonnage. This average rate was the highest in 10 years, with the exception of the 1990 to 1991 Persian Gulf War time period, when very large crude carriers (VLCCs) were pulled out of service and used for floating storage. ${ }^{103}$

As the international marine industry continues to comply with the phased implementation of the Oil Pollution Act of 1990 (OPA) (see the box entitled "The Oil Pollution Act of $\left.1990^{\prime \prime}\right)$, the issue of whether to abandon or stay in international marine operations becomes more crucial.

\section{The Oil Pollution Act of 1990}

The enactment of the Oil Pollution Act of 1990 requires that all newly-built tankers sailing in U.S. waters must have double-hulls by 1994 and bans all single-hull tankers from U.S. coastal waters by 2010 . The Act also requires shippers plying the U.S. waters to present evidence that they have in place credible oil spill response programs. In addition, the maximum limit on oil-spill liability at the Federal level and the liabilities the States can seek went into effect on December 28, 1994. ${ }^{a}$ Under this regulation, the tanker owner entering U.S. waters must possess a Certificate of Financial Responsibility, which shows evidence of financial responsibility at a rate 10 times that of the prior rate, or a rate of $\$ 1,500$ per gross register ton compared to $\$ 150$ a ton in the past. ${ }^{.}$

\footnotetext{
${ }^{a}$ U.S. Department of Energy, Transporting U.S. Oil Imports: The Impact of Oil Spill Legislation on the Tanker Market, DOE/EP/79095t-H1 (Washington, DC, June 1992), p. 91.

"Threat of Disruption in Oil Supply is Eased," The New York Times (December 22, 1994), p. D3.
}

\footnotetext{
98،"TAPS Reduced Flow to Reflect N. Slope Decline,"Oil and Gas Journal (June 10, 1996), p. 30; and "The Hot Seat: Bob Malone Takes Over a Company in Transition," Anchorage Daily News (September 1, 1996) Final Edition, p. 1C.

${ }^{99}$ ARCO, 1995 Annual Report, pp. 8 and 15; and Phillips Petroleum Corporation, 1995 Securities and Exchange Commission Form 10-K, pp. 13 and 14.

${ }^{100}$ Shell Oil Company, 1995 Annual Report, p. 37; and Shell Oil Company, 1995 Securities and Exchange Commission Form $10-K$, p. 14.

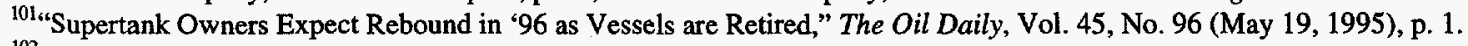

${ }^{102}$ Cambridge Energy Research Associates, World Oil Trends, 1996 Edition (Cambridge, MA, 1996), Table 35.

${ }^{103}$ Cambridge Energy Research Associates, World Oil Trends, 1996 Edition (Cambridge, MA, 1996), Table 35.
} 
Faced with historically low freight rates, regulations, and liabilities enacted by OPA and an aging world tanker fleet-the average fleet age is 13 years ${ }^{104}$-FRS companies have reacted variously. While some companies have exited the industry, or downsized tanker operations, and/or chartered vessels, others have decided to remain in marine operations.

In addition to Texaco's departure, Amoco sold the remainder of its tankers to Norway's Bona shipping and now charters three international marine tankers-an action taken to reduce liability risks associated with OPA. ${ }^{105}$ Similarly, Shell discontinued the transport of crude oil into U.S. waters and has decided only to transport oil overseas. ${ }^{106}$ The International Maritime Organization implemented the 1992 Marpol amendments in July 1995, which require vessels more than 25 years old to have double-hulls. ${ }^{107}$ As a result, in 1995 Shell Oil purchased four double-hulled crude oil carriers in a series of five to be delivered. ${ }^{108}$

With the exit of a sizable number of oil majors from international marine operations, the shipping business is dominated largely by independent companies. Major oil companies (including the U.S.-based FRS companies), which used to own most of the business, now own less than 10 percent of the world's overall tanker capacity. ${ }^{109}$ This trend, in part, reflects growth in chartering. For example, BP decided to charter the three double-hull vessels it had originally agreed to purchase to replace its aging fleet in order to avoid additional debt while still gaining access to new vessels. ${ }^{110}$ In addition, the company has downsized since 1983 by nearly 80 vessels, ${ }^{111}$ and in 1995 it wrote off $\$ 80$ million for tankers. ${ }^{112}$

Conversely, Mobil and Chevron have opted to stay in the business. According to Mobil, the company stays in the tanker business "to avoid risks, ensure cost-effective crude supplies and maintain control over much of the raw material that is the company's lifeblood."113 Mobil purchased a double-hull tanker, making it the second double-hull VLCC in its fleet. ${ }^{114}$ Similarly, Chevron has decided to stay in the business, also opting to own and operate its own vessels. Chevron operates the largest fleet among the majors. ${ }^{115}$ At year-end, under its modernization fleet program, the company owned and chartered 12 double-hull vessels out of a fleet of $35 .^{116}$

\section{LNG Trade: A New-Old Investment Target}

Most natural gas is transported through pipelines. However, when certain geographic locations are not feasible for pipeline construction, marine transport is used. The liquefied natural gas (LNG) industry celebrated its 30th year of international trade in $1995 .{ }^{117}$ Liquefied natural gas is a gas that is converted into a liquid state for purposes of transport and is later converted back into its original gaseous state for consumption after it arrives at its destination.

The year 1995 saw more commitments to new LNG developments, probably the most since the 1970's. The FRS companies' investment in LNG projects were located in Trinidad and Tobago, Qatar, Nigeria, Oman, Venezuela, and Brunei. These investments and developments included:

Amoco in Trinidad and Tobago. Amoco became a major player in a joint venture with Atlantic LNG Company of Trinidad and Tobago for the development of a \$1-billion LNG export plant in Trinidad. Amoco will supply 100 percent of the natural gas for the plant over the next 20 years. Development of the plant will begin in early 1996 and will be constructed for future LNG expansion. The LNG will be exported, beginning in 1999, to the U.S. and Europe. ${ }^{118}$

Mobil in Qatar. Mobil began two LNG projects, Qatargas and Ras Laffan, in partnership with the Qatar General Petroleum Corporation (QGPC) in Qatar. The Qatargas

\footnotetext{
${ }^{104}$ Washington Post (June 23, 1996), p. H1.

${ }^{105}$ Amoco Corporation, 1995 Securities and Exchange Commission Form 10-K, p.15.

106“A Legacy of Confusion," 1995 Asset Finance \& Leasing Digest, No. 219 (May 1995), pp. 24-27.

${ }^{107}$ "Supertank Owners Expect Rebound in '96 as Vessels are Retired," The Oil Daily, Vol. 45, No. 96 (May 19, 1995), p. 1.

${ }^{108}$ “A Legacy of Confusion," 1995 Asset Finance \& Leasing Digest, No. 219 (May 1995), pp. 24-27.

${ }^{109}$ “Supertank Owners Expect Rebound in '96 as Vessels are Retired," The Oil Daily, Vol. 45, No. 96 (May 19, 1995 ), p. 1.

110“'UK: Backers Win BP Tanker Debt Deal," Lloyds List (August 7, 1996), p. 1.

${ }^{111}$ Petroleum Intelligence Weekly (November 6, 1995), p. 2.

${ }^{112}$ British Petroleum Inc., 1995 Audited Consolidated Financial Statements, p. 11.

${ }^{113}$ Washington Post (June 23, 1996), p. H1.

114"Double-Hull VLCC Joins Fleet," Oil and Gas Journal, Vol. 94 (August 5, 1996), p. 36.

${ }^{115}$ Petroleum Intelligence Weekly (November 6, 1995), p. 2.

${ }^{116}$ Chevron Corporation, 1995 Securities and Exchange Commission Form 10-K, p. 20.

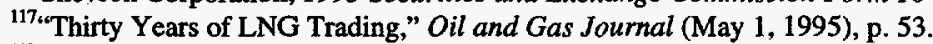

${ }^{118}$ Amoco Corporation, 1995 Annual Report, pp. 11 \& 12, and "Amoco Group Sets Trinidad LNG Project," Oil \& Gas Journal ( July 8, 1996 ), p. 36.
} 
project will produce natural gas and condensate in 1996, and the first cargo of LNG will be delivered to Japan in early 1997. The Ras Laffan LNG Company signed an agreement to supply Korea with 2.4 million tons of LNG annually for 25 years beginning in 1999. ${ }^{119}$

Shell in Nigeria, Oman, Venezuela, and Brunei. Royal Dutch/Shell Group, the parent corporation of FRS respondent Shell Oil, has undertaken a number of LNG projects. A joint venture between Shell Petroleum Development and Nigeria was approved to begin the Nigeria LNG project. The project will cost $\$ 4$ billion, and Shell will supply more than 50 percent of the gas to the Nigerian market, with delivery beginning in 1999. Shell has under development LNG projects in Oman and in Venezuela. ${ }^{120}$ In 1995, construction of the Malaysia LNG Dual plant continued and the first LNG cargo from the plant was delivered to Taiwan. Two new LNG carriers were purchased to carry the LNG cargo for the Dual plant expansion. The company also signed a long-term contract to sell Australian LNG to Japanese customers. In addition, Shell produces natural gas in Brunei ${ }^{121}$ and in 1995 began exporting LNG cargoes to South Korea. ${ }^{122}$

Chevron and Texaco in Australia. Chevron, Texaco, and partners are developing two huge natural gas fields in offshore western Australia-Gorgon and Chrysaor. ${ }^{123}$ The Gorgon field was discovered in the 1980's but judged not viable due to a lack of market opportunities. However, with the rise in gas consumption in Asia, LNG production is now viable. The Gorgon deposits are owned by a consortium, with Chevron and Texaco each owning 28.6 percent. ${ }^{124}$ In addition, Chevron owns an interest in six LNG ships that are chartered to the Australian North West Shelf Project. These ships, along with two time-chartered LNG vessels, transport LNG from Australia to various Japanese gas and electric utilities. ${ }^{125}$

Enron in Qatar. In 1995, Enron signed a nonbinding agreement with the Qatar General Petroleum Cooperation for the development of five million tons of LNG from Qatar's North Dome Field and the construction of an LNG facility. Enron is currently identifying markets in Israel, Jordan, and India prior to the development of the reserves. Under the terms of the agreement Enron would develop the reserves and construct both a liquefication plant in Qatar and a re-gasification facility at sites in the referenced markets. ${ }^{126}$

Phillips Venture to license proprietary LNG technology. Phillips plans to team-up with other companies to develop new gas markets around the world using its patented LNG process. The company's LNG process was used at the Kenai plant for 26 years. Phillips exports LNG from its Kenai, Alaska, plant to utility companies in Japan. ${ }^{127}$

${ }^{119}$ Mobil Corporation, 1995 Mobil Fact Book, A Supplement to the Annual Report, pp. 24 \& 34.

${ }^{120}$ Royal Dutch Pecroleum Company, 1995 Annual Report, p. 19.

${ }^{121}$ Royal Dutch Petroleum Company, 1995 Annual Report, p. 17.

${ }^{122}$ Royal Dutch Petroleum Company, 1995 Annual Report, p. 23.

${ }^{123}$ Chevron Corporation, 1995 Annual Report, pp. 12 \& 13.

124،Asian Demand Boosts Australian LNG Industry; Liquefied Natural Gas; Industry Overview," Gas World International, Vol. 199, No. 4914 (May 1995), p. 30.

${ }^{125}$ Chevron Corporation, 1995 Securities and Exchange Commission Form 10-K, p. 20.

${ }^{126}$ Enron Corporation, 1995 Annual Report, pp. 28 \& 34

${ }^{127}$ Phillips Petroleum Corporation, 1995 Annual Report, p. 13. 


\section{Coal and Alternative Energy}

\section{Coal}

Domestic coal consumption increased slightly, by 1 percent, during 1995, largely because of a similar increase in electric utilities' use. ${ }^{128}$ Flat domestic consumption, coupled with essentially unchanged coal users' inventories, including electric utilities, ${ }^{129}$ did little to brake the fall in coal prices. Average prices for the U.S. coal industry fell for the 16th consecutive year, a 4-percent reduction that matched that of $1994 .{ }^{130}$ Providing some offset, however, was a 24-percent increase in coal exports, as sales to most of the leading importers of U.S. coal increased during 1995, led by increases to the Netherlands, Germany, Denmark, Italy, and Japan. ${ }^{131}$
Taken together, U.S. shipments of coal to these countries increased by 8.9 million short tons in 1995 . Lower production costs also provided some relief to coal producers, a benefit that was slightly magnified as domestic production was about even with 1994 production..$^{132}$ Miner productivity, which increased in both underground and surface mines by 6 percent and 11 percent, respectively, added to the efficiency of domestic coal operations. ${ }^{133}$

Although FRS coal production fell 8 percent in 1995, operating income from coal operations increased 56 percent (Table 26). The drop in FRS coal production was largely due to a large domestic coal divestiture by Exxon.

Table 26. Coal Financial and Operating Indicators for the FRS Companies, 1994-1995 (Million Dollars)

\begin{tabular}{|c|c|c|c|}
\hline \multicolumn{4}{|l|}{ Coal Financial Indicators } \\
\hline $\begin{array}{l}\text { Coal Revenues } \ldots \ldots \ldots \ldots \ldots \ldots \ldots \ldots \ldots \ldots \ldots \ldots \ldots \\
\text { General Operating Expenses (excludes taxes }\end{array}$ & 2,745 & 3,508 & 27.8 \\
\hline and unusual items $)^{a} \ldots \ldots \ldots \ldots \ldots \ldots \ldots \ldots$ & 1,781 & 2,195 & 23.2 \\
\hline General and Administrative $\ldots \ldots \ldots \ldots \ldots \ldots \ldots$ & 80 & 97 & 21.3 \\
\hline \multirow[t]{2}{*}{ Operating Income (excludes unusual items) ${ }^{a}$} & 360 & 561 & 55.8 \\
\hline & \multicolumn{2}{|c|}{ (million tons) } & \\
\hline
\end{tabular}

QUnusual items totaled $\$ 199$ million (pretax) in charges and $\$ 126$ million (after tax) in charges in 1994, and $\$ 220$ million (pretax) in charges and \$184 million (after tax) in charges in 1995.

Sources: Energy Information Administration, Form ElA-28.

\footnotetext{
${ }^{128}$ Energy Information Administration, Annual Energy Review 1995, DOE/EIA-0384(95) (Washington, DC, July 1996), Table 7.3.

${ }^{129}$ Energy Information Administration, Annual Energy Review 1995, DOE/EIA-0384(95) (Washington, DC, July 1996), Table 7.5.

${ }^{130}$ Energy Information Administration, Annual Energy Review 1995, DOE/EIA-0384(95) (Washington, DC, July 1996), Table 7.8; and Energy Information Administration, Performance Profiles of Major Energy Producers 1994, DOE/EIA-0206(94) (Washington, DC, February 1996), Table 25.

${ }^{131}$ Energy Information Administration, Annual Energy Review 1995, DOE/EIA-0384(95) (Washington, DC, July 1996), Table 7.4.

${ }^{132}$ Energy Information Administration, Annual Energy Review 1995, DOE/EIA-0384(95) (Washington, DC, July 1996), Table 7.2.

${ }^{133}$ Energy Information Administration, Coal Industry Annual 1995, DOE/EIA-0584(95) (Washington, DC, October 1996), Tables 49 and 50.
} 
Similarly, the large increase in operating income was more an indication of the degree to which FRS coal operations changed during 1995, and less an indication that FRS companies realized higher profit margins during 1995 than in $1994 .{ }^{134}$

A fairly steady trend in FRS coal operations since 1989 has been the exit of FRS firms from the domestic coal industry, as 6 companies sold their coal assets (or held the assets for sale) between 1989 and $1994 .{ }^{135}$ The year 1995 was unique because two FRS companies, Sun and Ashland, reconsolidated their domestic coal operations. Sun sold many of its coal assets during 1993 and intended to leave the industry, carrying its remaining coal assets as a discontinued operation. During 1995, however, Sun ceased trying to sell its remaining coal assets and reconsolidated the assets. ${ }^{136}$ Ashland, on the other hand, had held less than 50 percent equity in Ashland Coal prior to 1995 (as it had since the summer of 1988 ), ${ }^{137}$ carrying Ashland Coal as an unconsolidated affiliate. However, when Saarbergwerke AG placed its 15-percent equity in Ashland Coal for sale, the parent company, Ashland, purchased the entire block and reconsolidated Ashland Coal. ${ }^{138}$ Reconsolidation of Sun Coal and Ashland Coal into the respective financial statements of Sun Company and Ashland represents an increased corporate commitment to coal operations in addition to altering the corporate financial results, including operating income.

In addition to the re-entry of two FRS firms into the domestic coal industry, overall FRS coal operations were substantially changed when Exxon sold approximately 80 percent of its domestic coal production capacity to foreign-owned Peabody Holding Company during 1994 (representing 60 percent of its worldwide coal production) ${ }^{139}$ This sale diminished the ranking of what had been one of the largest domestic producers of coal while increasing the proportion of foreign (versus domestic) coal produced by FRS companies. ${ }^{140}$ Further, Coastal recently announced that its coal operations are for sale, ${ }^{141}$ implying that the longer trend of FRS exit from coal operations may continue.

Sizable changes, such as those of Sun, Ashland, and Exxon obscure the performance of continuing FRS coal producers. Table 27 presents financial and operating information for a consistent group of domesticallyoriented FRS coal producers. Average revenues of these companies were essentially unchanged, and average operating expense increased only slightly for 1995

Table 27. Financial and Operating Items for Continuing FRS Coal Producers, 1994-1995 (Dollars per Ton)

\begin{tabular}{|c|c|c|c|}
\hline Ratios & 1994 & 1995 & $\begin{array}{c}\text { Percent Change } \\
\text { 1994-1995 }\end{array}$ \\
\hline \multicolumn{4}{|l|}{ Dollar per Ton Produced } \\
\hline Revenues .......... & 18.27 & 18.39 & 0.6 \\
\hline Total Operating Expense & 16.11 & 16.42 & 1.9 \\
\hline Operating Income ... & 2.16 & 1.97 & -9.0 \\
\hline Production (million tons) ${ }^{a}$ & 137 & 154 & 8.2 \\
\hline
\end{tabular}

'Includes ARCO's U.S. production and Ashland's proportionate share of subsidiaries' production. Includes only continuing FRS coal producers.

Source: Energy Information Administration, Form EIA-28, Financial Reporting System.

\footnotetext{
${ }^{134}$ The financial information collected for FRS coal operations is for their world-wide operations, while the production and reserves information is only for their domestic operations. Hence, the incorrect appearance that the prices received increased nearly 40 percent. Instead, FRS coal operations became more oriented toward foreign production, which did seem to receive higher prices in 1995 than in 1994, and away from domestic production. This was chiefly due to Exxon's sale of 80 percent of its domestic coal production (60 percent of their world-wide production) during 1994 (See Exxon Corporation, 1994 Annual Report, p. 20 and 1995 Financial and Operating Review, p. 72.). p. 48.

${ }^{135}$ Energy Information Administration, Performance Profiles of Major Energy Producers 1994, DOE/EIA-0206(94) (Washington, DC, February 1996),

${ }^{136}$ Sun Corporation, 1995 Annual Report, p. 20 and 1995 Securities and Exchange Commission Form 10-K, p. 11.

137" Ashland Coal equity ownership changes," Financial Times (August 26, 1988).

138. Industry Updates; Costain Group Eyes More Selloffs," Coal Week, Vol. 21, No. 7 (February 13, 1995), p. 2 and "Clarification," Coal Outlook, Vol. 20, No. 26 (July 1, 1996).

${ }^{139}$ Exxon Corporation, 1994 Annual Report, p. 20; and 1995 Financial and Operating Review, p. 72.

${ }^{140}$ Exxon Corporation, 1994 Annual Report, p. 20; and Energy Information Administration, Coal Industry Annual 1994, DOE/EIA-0584(94) (Washington, DC, October 1995), Table 14.

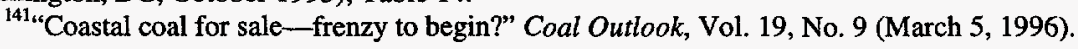


relative to expenses in 1994. However, operating income for continuing producers held steady because of an 8-percent increase in production.

\section{Alternative Energy}

The FRS companies' investments in alternative energy were largely in cogeneration, electric power generation, geothermal, and tar sands. These operations accounted for 97 percent of the companies' alternative energy revenues in 1995. ${ }^{142}$ Four companies-Enron, ARCO, Coastal, and Texaco-were principally responsible for the FRS companies' investment in cogeneration and electric power generation facilities. Similarly, Sun and Exxon are largely responsible for FRS investment in oil production from Canadian tar sands, although Sun sold all of its Canadian operations in 1995, while Unocal primarily accounted for the FRS companies' investment in geothermal production.

The financial performance of FRS companies involved in alternative energy operations continued to grow in 1995. Overall revenue increased 9 percent compared to revenues in the prior year (Table 28). Revenue benefitted from record levels of oil production from tar sands operations, coupled with increased oil prices, and improved performance in electric power generation and cogeneration. Exxon reported record levels of production from tar sands, totaling 202,000 barrels a day, ${ }^{143}$ up 70 percent from 1994, making it the sixth consecutive year the company has achieved record volumes. Sun, however, reported a decline in revenue of $\$ 14$ million due to the divestiture of Suncor, the company's Canadian petroleum subsidiary. ${ }^{144}$ Enron's revenue improved due to increased promotional and developmental activities in electric power operations. ${ }^{145}$

Revenue growth was offset by a 10-percent rise in operating expenses (excluding unusual items), an increase due to due to Enron's stepped-up pace in international power generation operations ${ }^{146}$ and the start up of Coastal's El Salvador operations. ${ }^{147}$ The 1995 increase in operating expenses brings to an end the fifth consecutive increase in earnings for the FRS companies' alternative energy business segment. Prior to 1990, the FRS companies realized operating losses from alternative energy activities in every year back to 1974 .

Overall capital expenditures increased 52 percent (Table 28). Investments in foreign operations were responsible for the increase, as domestic expenditures declined 23

Table 28 Revenues, Income, and Investment in Other Energy for FRS Companies, 1994-1995 (Million Dollars)

\begin{tabular}{|c|c|c|c|}
\hline Item & 1994 & 1995 & $\begin{array}{c}\text { Percent Change } \\
1994-1995 \\
\end{array}$ \\
\hline \multicolumn{4}{|l|}{ Revenues and Expenses } \\
\hline Revenues....... & 1,296 & 1,408 & 8.6 \\
\hline Operating Expenses ${ }^{a}$ & 1,100 & 1,214 & 10.4 \\
\hline Operating Income ${ }^{\mathrm{a}}$ & 196 & 194 & -1.0 \\
\hline \multicolumn{4}{|l|}{ Additions to Investment in Place ${ }^{b}$} \\
\hline United States $\ldots \ldots \ldots \ldots$ & 77 & 59 & -23.4 \\
\hline Foreign $\ldots \ldots \ldots \ldots \ldots$ & 177 & 327 & 84.7 \\
\hline Total .. & 254 & 386 & 52.0 \\
\hline
\end{tabular}

${ }^{\mathrm{a} E x c l u d e s}$ unusual items.

${ }^{\mathrm{b}}$ Additions to net property, plant, and equipment and advances to unconsolidated subsidiaries.

Source: Energy Information Administration, Form EIA-28.

\footnotetext{
${ }^{142}$ Solar power earnings were not reported due to the joint venture between Amoco Corporation and Enron Corporation in January 1995 . Source: Amoco Corporation, 1995 Securities and Exchange Commission Form I0-K, p. 18.

${ }^{143}$ Exxon Corporation, 1995 Annual Report, p. 11. Exxon Corporation, 1994 Financial and Operating Review, p. 35.

${ }^{144}$ Sun Company, 1995 Annual Report, p. 32, and "Sun Oil Set to Raise Cdollars 1.1 bn by Selling 50\% Stake in Suncor," Financial Times (May 25, 1995), International Section, p. 29.

${ }^{145}$ Enron Corporation, 1995 Securities and Exchange Commission Form 10-K, p. 38.

${ }^{146}$ Enron Corporation, 1995 Securities and Exchange Commission Form 10-K, p. 38.

${ }^{147}$ Coastal Corporation, 1995 Annual Report, p. 39.
} 
percent compared to expenses in 1994 (Table 28). The boost in foreign expenditures of 85 percent was attributable primarily to the operations of three companiesCoastal, Enron, and Unocal-and was driven by privatizations in Asia and in Latin America (Table 29). For example, Enron's expenditures more than quadrupled to $\$ 58$ million, up from $\$ 14$ million in $1994,{ }^{148}$ and Coastal's expenditures increased from near zero in 1994 to $\$ 12$ million in 1995. ${ }^{149}$ Unocal's investments in geothermal sources increased 46 percent, up from $\$ 34$ million in $1994 .{ }^{150}$
As in other lines of activity, FRS companies' investments in alternative energy have been the focus of restructuring. As mentioned earlier, Sun sold its remaining 55 percent interest in Suncor, its Canadian petroleum subsidiary, thereby ending the company's operations in tar sands operations. Sun reported that the sale of its shares was due to tar sands' operations not being a core asset of the company. ${ }^{151}$ The company began the divesture of its operations in 1993, when it reduced its ownership interest in Suncor from 68 percent to 55 percent. ${ }^{152}$ Also in 1995, Kerr-McGee disposed of its renewable fuels operations at its refinery in Corpus Christi, Texas, when the company exited the refining and marketing business. ${ }^{153}$

${ }^{148}$ Enron Corporation, 1995 Securities and Exchange Commission Form 10-K, p.41.

${ }^{149}$ Coastal Corporation, 1995 Annual Report, p. 56.

${ }^{150}$ Unocal Corporation, 1995 Annual Report, pp. 12 and 13.

${ }^{151}$ Sun Company, 1995 Annual Report, p. 32, and "Sun Oil Set to Raise C Dollars 1.1bn By Selling 50\% Stake in Suncor," Financial Times (May 25, 1995), International Section, p. 29.

${ }^{152}$ Sun Company, 1995 Annual Report, p. 41.

${ }^{153}$ Kerr-McGee Corporation, 1995 Securities and Exchange Commission Form 10-K, p. 18; and Kerr-McGee Corporation, 1994 Securities and Exchange Commission Form 10-K, p. 13. 
Table 29. FRS Companies' Foreign Other Energy Projects in 1995

\begin{tabular}{|c|c|c|}
\hline Company & Projects & Status in 1995 \\
\hline \multirow[t]{2}{*}{ Enron Corporation } & $\begin{array}{l}154 \text { megawatt diesel/gas combined cycle power plant in } \\
\text { Hainan Island, Chinaa }\end{array}$ & Construction in progress \\
\hline & $\begin{array}{l}\text { 2015-megawatt gas-fired power plant in Dahbol, India which } \\
\text { consisted of the initial infrastructure and the construction of } \\
\text { phase I from March to August } 1995^{\text {b }}\end{array}$ & $\begin{array}{l}\text { Preliminary agreement reached } \\
\text { in } 2 / 96 \text { to continue project }\end{array}$ \\
\hline \multirow[t]{4}{*}{ Coastal Corporation } & 91-megawatt power plant in Nejapa, El Salvadord & Operation came on line in 1995 \\
\hline & 53-megawatt expansion of the plant in Nejapa, El Salvador ${ }^{\circ}$ & Construction in progress \\
\hline & $\begin{array}{l}\text { Purchased 48-percent interest in a Dominican Republic } \\
\text { power plant that owns a } 66.5 \text { megawatt, heavy-fuel-oil fired } \\
\text { power project }\end{array}$ & \\
\hline & Simple-cycle, diesel-fired plant in Wuxi City, China ${ }^{i}$ & Operation came on line in 1995 \\
\hline Unocal Corporation & $\begin{array}{l}\text { Three new 55-megawatt electric power plants at the Salak } \\
\text { field on the island of Java, Indonesia I }\end{array}$ & Construction in progress \\
\hline
\end{tabular}

"Enron Corporation, 1995 Annual Report, p. 11.

Enron signed a Power Purchase Agreement on December 8, 1993 with the State of Maharastra to construct both phase I and II of a 2015 megawatt gas-fired power plant and related facilities, including a liquefied natural gas terminal. In March 1995, the company began the construction of phase I. However, almost 6 months later, construction came to a halt after a new governing coalition was elected in the State of Maharashtra. After months of negotiations, a preliminary agreement in February 1996 was reached between Dabhol Power Company (Enron's 80-percent owned subsidiary), the State government and the Maharashtra State Electricity Board to go forward with an expanded project. However, Phase I will be built with a capacity of 826 megawatts and will now burn naptha/ distillate as fuel instead of natural gas, with a potential expansion up to 2450 megawatts being fueled by imported liquefied natural gas. Source: Enron Corporation, 1995 Securities and Exchange Commission Form 10-K, p.12.

'Enron Corporation, 1995 Securities and Exchange Commission Form 10-K, p.12.

'Coastal Corporation, 1995 Annual Report, p. 29.

${ }^{\circ}$ Coastal Corporation, 1995 Annual Report, p. 29.

'Coastal Corporation, 1995 Annual Report, p. 31.

${ }^{8}$ Coastal Corporation, 1995 Annual Report, p. 31.

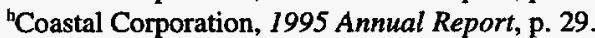

'Coastal Corporation, 1995 Annual Report, p. 39.

'Unocal Company, 1995 Annual Report, pp. 2 \& 13. 



\section{Foreign Direct Investment in U.S. Energy}

\section{Foreign Acquisitions and Divestitures of U.S. Energy Assets}

Lackluster profitability, both upstream and downstream, along with more stringent environmental requirements have apparently reduced the attractiveness of U.S. petroleum as a target of investment for foreign companies. In 1994, ${ }^{154}$ acquisitions that affected the foreign direct investment position ${ }^{155}$ ("FDI-related" acquisitions) in U.S. petroleum and coal totaled $\$ 1.0$ billion in value (Table 30 ), down considerably from $\$ 4.6$ billion one year earlier (Figure 24). Divestitures (i.e., the sale of U.S. energy assets) by foreign-affiliated companies, at $\$ 1.5$ billion, exceeded acquisitions for the first time. The reduced attraction of petroleum relative to other U.S. investment targets is evident in the petroleum share of total FDI. The petroleum share peaked at 15 percent in 1984-1985, fell to 11 percent by 1990 , and most recently hit 7 percent (Table 31). Coal continued to be the major focus of foreign direct investment in U.S. energy in 1994, while petroleumrelated investment declined substantially from recent years' levels. There were virtually no FDI-related acquisitions in U.S. refining in 1994, as the number of foreign-affiliated refineries in the United States held steady.

\section{Coal Acquisitions and Divestitures}

Coal operations accounted for more than half the value of FDI-related acquisitions in U.S. energy in 1994. The prominence of coal as a target of foreign investors in 1994 was part of a continuing trend in the 1990's (see the section "The Globalization of World Coal Investment" at the end of this chapter). In four of the last five years, the largest FDI-related transaction in U.S. energy involved coal assets. The most prominent foreign investors are from Germany and the United Kingdom (UK). Companies from these countries continued to increase their share of the U.S. coal market in 1994. Peabody Holding Co., a subsidiary of the United Kingdom's Hanson plc, purchased Carter Mining Co. from Exxon for a reported $\$ 360$ million (see the box entitled "Major FDI-Related Transactions in U.S. Energy 1994"). Further, the United Kingdom's RTZ Corp. plc, through its wholly-owned U.S. subsidiary, Kennecott Corp., acquired Colowyo from WR Grace for $\$ 233$ million. Consol Energy Inc., a joint venture between DuPont and Germany's RWE, acquired Kentucky Criterion Coal Co. for $\$ 81$ million.

\section{Oil and Gas Acquisitions and Divestitures}

Exceptionally low crude oil prices and falling natural gas prices may have discouraged acquisitions of U.S. upstream assets in 1994. In 1994, inflation-adjusted crude oil prices reached their lowest levels in the last two decades, while natural gas wellhead prices were 10 percent lower than in the previous year. ${ }^{156}$ In 1994, the value of upstream acquisitions dropped to a 14-year low (Table 30), and, for the first time, the value of oil and gas divestitures exceeded acquisitions. The largest oil and gas divestiture involved the exit of Bridge Oil, an Australian company, from U.S. upstream operations. Although Bridge Oil purchased $\$ 48$ million in producing properties from Santa Fe Energy Resources (a Canadian-affiliated company) early in 1994, Bridge Oil was acquired by Parker and Parsley in July, 1994, in a transaction valued at \$584 million. ${ }^{157}$ Two-thirds of Bridge Oil's total oil and gas reserves were located in the United States and operated by their U.S. subsidiary, Bridge Oil (USA). Another oil and gas transaction exceeding $\$ 100$ million in 1994 involved the Italian Agip's sale of offshore Gulf of Mexico properties to Occidental Petroleum for $\$ 195$ million.

\footnotetext{
${ }^{154}$ The focus year for foreign direct investment in this report is 1994, not 1995, in that financial performance data (covered in the other chapters of this report) is available earlier than foreign investment data.

${ }^{155}$ The foreign direct investment (FD) position is the cumulative net flow of funds between a foreign-affiliated company and its foreign owners. The U.S. Department of Commerce, the agency that collects data on FDI, measures FDI as the book value of foreign direct investors' equity interest in and net outstanding loans to their U.S. affiliates. The Department of Commerce defines a U.S. affiliate as a U.S. business enterprise in which one foreign direct investor owns 10 percent or more of the voting securities or the equivalent.

${ }^{156}$ Energy Information Administration, Monthly Energy Review, DOE/EIA-0035(95/09) (Washington, DC, September 1995), Tables 9.1 and 9.11.

${ }^{157}$ Parker \& Parsley, 1994 Annual Report, p. 42
} 
Table 30. Value of FDI-Related Transactions in U.S. Energy, 1990-1994 (Million Dollars)

\begin{tabular}{|c|c|c|c|c|c|}
\hline Acquisitions/Divestitures & 1990 & 1991 & 1992 & 1993 & 1994 \\
\hline \multicolumn{6}{|l|}{ Acquisitions } \\
\hline Oil and Gas Production ${ }^{a}$ & 901 & 1,043 & 949 & 1,246 & 329 \\
\hline Petroleum Refining, Marketing and Transport ......... & 1,040 & 103 & 173 & 1,264 & 0 \\
\hline$\ldots \ldots \ldots \ldots$ & 1,416 & 570 & 1,276 & 1,928 & 674 \\
\hline Other Energy $\ldots \ldots \ldots \ldots \ldots \ldots \ldots \ldots \ldots \ldots \ldots$ & 0 & 0 & 0 & 150 & 0 \\
\hline Total Acquisitions $\ldots \ldots \ldots \ldots \ldots \ldots \ldots \ldots \ldots$ & 3,357 & 1,716 & 2,398 & 4,588 & 1,013 \\
\hline \multicolumn{6}{|l|}{ Divestitures } \\
\hline Oil and Gas Production ${ }^{a}$ & 474 & 736 & 461 & 938 & 663 \\
\hline Petroleum Refining, Marketing, and Transport ........ & 59 & 400 & 60 & 822 & 41 \\
\hline $\mathrm{Coa}^{b} \ldots \ldots \ldots \ldots \ldots \ldots \ldots \ldots \ldots \ldots \ldots \ldots$ & 841 & 155 & 869 & 438 & 768 \\
\hline Other Energy & 0 & 0 & 0 & 0 & 0 \\
\hline Total Divestitures . . . . . . . . . . . . . . . . . . & 1,374 & 1,291 & 1,390 & 2,198 & 1,472 \\
\hline \multicolumn{6}{|c|}{$\begin{array}{l}\text { ancludes drilling and drilling services. } \\
\text { b1990 includes Newmont Mining's sale of its } 55 \text {-percent interest in Peabody Holding Company for } \$ 726 \text { million, while } 1992 \\
\text { includes Shell Oil's divestiture of its coal operations for } \$ 850 \text { million. } \\
\text { Sources: 1994: Based on Tables C1 and C2 in Appendix C. 1993: Based on Tables A1, A2, and A3 in Energy Information } \\
\text { Administration, Profiles of Foreign Direct Investment 1993, DOE/EIA-0466(93) (Washington, DC, May 1995). 1992: Based on } \\
\text { Tables A1 and A2 in Energy Information Administration, Profiles of Foreign Direct Investment in U.S. Energy 1992, DOE/EIA- } \\
\text { 0466(92) (Washington, DC, May 1994). 1991: Based on Tables A1 and A2 in Energy Information Administration, Profiles of } \\
\text { Foreign Direct Investment in U.S. Energy 1991, DOE/EIA-0466(91) (Washington, DC, April 1993). 1990: Based on Tables A1 } \\
\text { and A2 in Energy Information Administration, Profiles of Foreign Direct Investment in U.S. Energy 1990, DOE/EIA-0466(90) } \\
\text { (Washington, DC, April 1992). }\end{array}$} \\
\hline
\end{tabular}

The largest oil and gas acquisition in 1994 was the Canadian Nova Corp's purchase of a 37-percent interest in NGC Corporation, which owns Natural Gas Clearinghouse, the largest independent gas marketing company in the United States. Gas marketing can be described as a midstream activity. Midstream operations in North America, such as natural gas marketing, have become increasingly important, along with the services of natural gas brokers and providers of various transportation services. According to a recent EIA report, "Today marketing companies play a significant role in the aggregating of supplies and in the selling of services that had previously been provided by pipeline companies." ${ }^{158}$ This has been due largely to the deregulation of the U.S. natural gas industry and the growing integration of U.S. and Canadian natural gas markets. In 1994, U.S. imports of Canadian natural gas were 13 percent higher than in1993. In 1994, Canada directed one-half of its production to the U.S. market and Canadian natural gas accounted for 13 percent of U.S. consumption. ${ }^{159}$

Despite the low level of acquisition activity in recent years, the remaining foreign affiliates' outlays for exploration and development in the United States were at a slightly higher level in 1994 than in the previous year (Table 32). Much of this new investment was for exploring and developing properties in the Gulf of Mexico. Anadarko and Shell Oil reported sizable increases in U.S. exploration and development expenditures. For both Anadarko and Shell, the Gulf of Mexico has become the focus of exploration and production spending.

In 1994, Shell Oil was the second largest producer of U.S. crude oil among foreign-affiliated companies and fourth largest overall. Shell ranked first, however, among offshore U.S. producers. A large and increasingly greater portion of Shell's U.S. upstream activity has been focused on the Gulf of Mexico. As a result of the development of Gulf of Mexico fields, Shell has been able to reverse its decline in U.S. oil and gas production, which began in 1986. ${ }^{160}$ Since 1990, Shell has reported a 45-percent increase in offshore Gulf of Mexico crude oil production. In 1994, 37 percent of Shell's crude oil production originated from Gulf of Mexico fields versus 23 percent in 1990. In 1994, offshore Gulf of Mexico natural gas

\footnotetext{
${ }^{158}$ Energy Information Administration, Natural Gas 1995: Issues and Trends, DOE/EIA-0560(95) (Washington, DC, October 1995 ), p. 1.

${ }^{159}$ Energy Information Administration, Monthly Energy Review, DOE/EIA-0035(95/09) (Washington, DC, September 1995), Table 4.2.

${ }^{160}$ Shell Oil Company, 1994 Annual Report, p. 2.
} 
Figure 24. Value of FDI-Related Acquisitions in U.S. Energy, 1981-1994

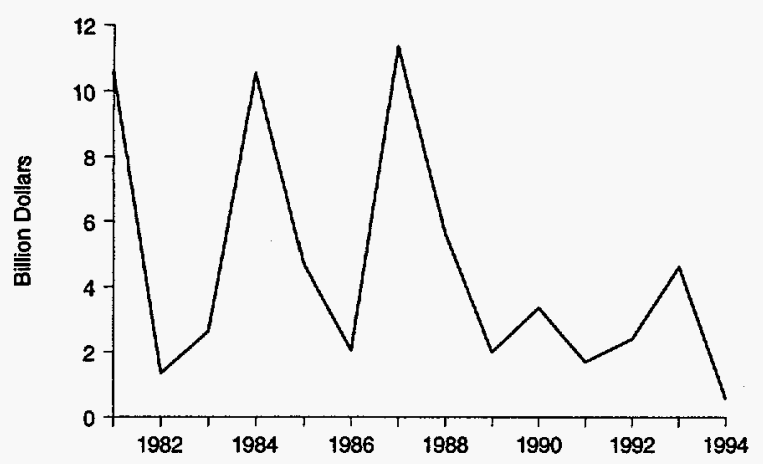

Sources: Value of FD1-related acquisitions: Tables $A 1, A 2$, and $A 3$ in the Appendix of this report and Tables A1, A2, and A3 from previous editions of this report. Change in FDI: calculated as annual change in FDI position, based on latest consistent set of revisions, appearing in the August issues (1985-1994) of U.S. Department of Commerce, Bureau of Economic Analysis, Sunvey of Current Business.

accounted for nearly half of Shell's total U.S. natural gas production. ${ }^{161}$ Shell reported acquiring 46 Federal Outer Continental Shelf (OCS) Gulf of Mexico tracts in 1994, emphasizing deep-water prospects.

Part of Shell's success in the Gulf of Mexico was due to Shell's leading role in adopting deep sea drilling technology. In 1994, Shell began production from the Auger platform in the Gulf of Mexico. The Auger platform, which cost about $\$ 1$ billion to construct, ${ }^{162}$ established a record for water-depth in the United States at 2,860 feet. ${ }^{163}$ Another Gulf of Mexico prospect, the Mars field, is expected to begin production in late 1996. It is estimated that the Mars field holds as much as 600 million barrels of crude oil. In order to develop the field, Shell installed an innovative tension leg platform at a depth of 2,933 feet. Shell holds a 71-percent interest in Mars, with BP America, another foreign affiliate, owning the remaining 29 percent.

Anadarko Petroleum, which is 10-percent owned by the Algerian government's Sonatrach, led the specialized oil and gas producers in terms of U.S. crude oil reserve additions in $1994 .{ }^{164}$ Anadarko spent a reported $\$ 72$ million to acquire OCS leases in the Gulf of Mexico.
Anadarko also reported drilling two sub-salt exploratory wells, as well as four conventional exploratory wells along with the installation of two production platforms in the Gulf of Mexico. ${ }^{165}$

\section{Refining/Marketing Acquisitions and Divestitures}

U.S. refining experienced very little merger and acquisition activity in 1994. In the United States, there were only four refineries which changed hands in 1994, none of which involved foreign ownership. Only one downstream financial transaction involving an FDI-affiliated company exceeded $\$ 25$ million. In 1994, DuPont sold a petroleum additives business to Great Lakes Chemical for $\$ 41$ million. Nevertheless, refining/marketing capital expenditures for foreign affiliates increased 18 percent between 1993 and 1994 (Table 32). A large increase in spending of 54 percent was registered by Shell Oil. Shell reported that they were upgrading their U.S. refineries to produce reformulated gasoline (RFG) and to reduce emissions at their Martinez, California, and Deer Park, Texas, refineries. Similarly, Total Petroleum reported that the company spent $\$ 250$ million for refinery upgrades in 1993 and 1994 (mostly for hydrotreating units), enabling its refineries to process more sulfurous crude oils while reducing the sulfur content of their petroleum products. ${ }^{166}$

\section{Overall Foreign Direct Investment}

The foreign direct investment (FDI) position is the cumulative net flow of funds between foreign-affiliated U.S.-based companies and their foreign owners. The U.S. Department of Commerce measures FDI as the book value of foreign direct investors' equity in and net outstanding loans to their U.S. affiliates. Total additions to FDI in 1994 were $\$ 40.3$ billion (Table 33), up from $\$ 36.5$ billion in 1993 , and up considerably from $\$ 8.5$ billion in 1992 , when additions to FDI were at their lowest level since 1972.

According to the U.S. Department of Commerce, the recent increases in FDI, "...resulted from stepped-up economic activity both in the United States and abroad that increased foreign investors' ability and incentive to invest in the United States. Their ability to invest was strengthened by the continued improvement in business conditions in certain major investor countries, such as the

\footnotetext{
${ }^{161}$ Shell Oil Company, 1994 Annual Report, p. 60.

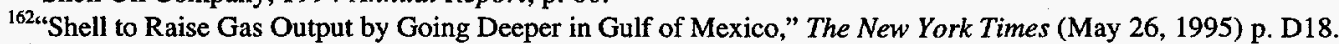

${ }^{163}$ Shell Oil Co., 1994 Annual Report, p. 11.

${ }^{164}$ Arthur Andersen \& Company, Oil \& Gas Reserve Disclosures (Chicago, 1995), p. 17.

${ }^{165}$ Anadarko Petroleum Corporation, 1994 Annual Report, pp. 5-6.

${ }^{166}$ Total Petroleum (North America) Ltd., 1994 Annual Report, pp. 12-13.
} 
Table 31. Foreign Direct Investment in U.S. Petroleum and Coal, 1980-1994 (Billion Dollars)

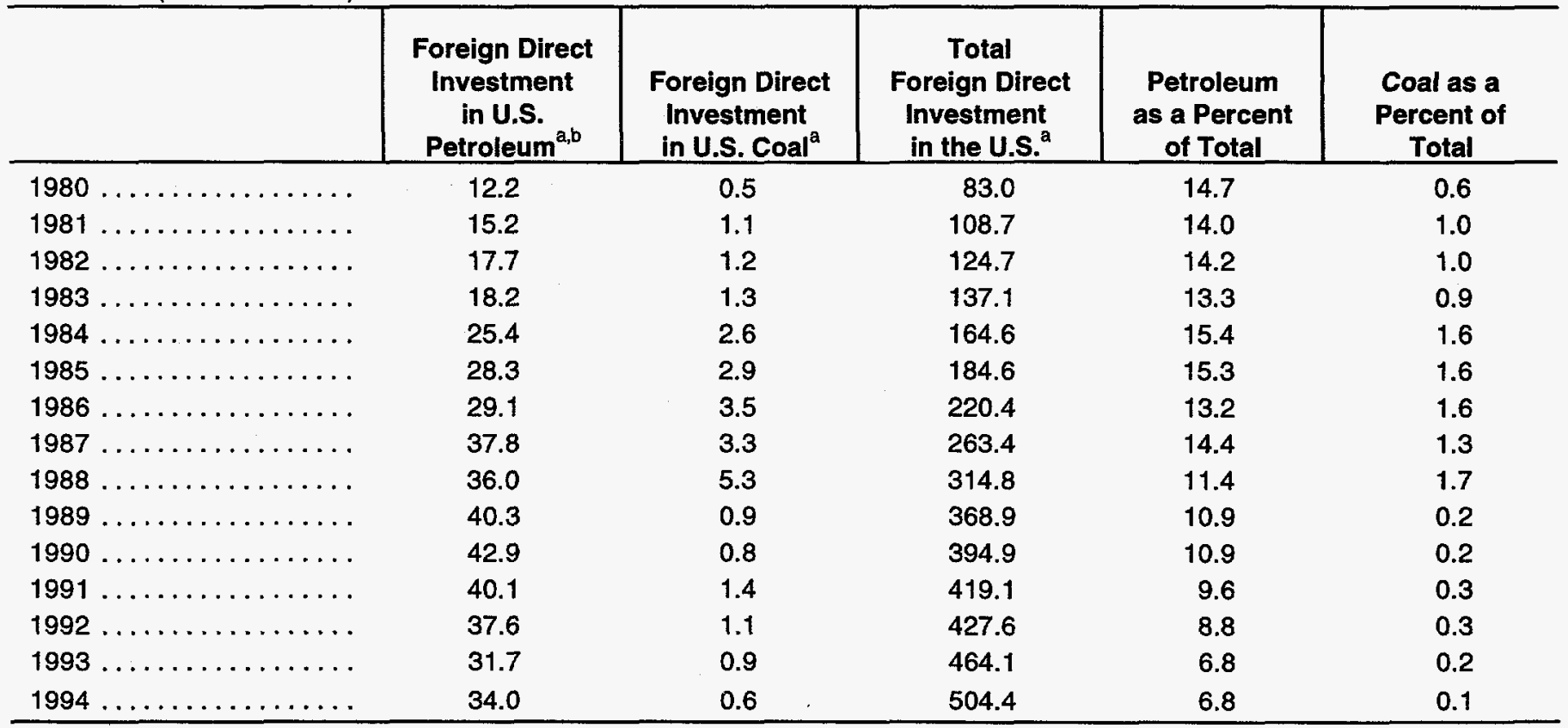

${ }^{2}$ Foreign direct investment (FDI) is the value of foreign parents' net equity in, and outstanding loans to, affiliates in the United States at the end of the year.

The petroleum industry includes all phases of oil and gas exploration and production, petroleum refining, petroleum transport, and petroleum marketing.

Sources: 1991-1994: U.S. Department of Commerce, Bureau of Economic Analysis, Survey of Current Business (Washington, DC, August 1995). 1987-1990: U.S. Department of Commerce, Bureau of Economic Analysis, Survey of Current Business (Washington, DC, August 1993). 1985-1986: U.S. Department of Commerce, Bureau of Economic Analysis, Survey of Current Business (Washington, DC, August 1990). 1981-1984: U.S. Department of Commerce, Bureau of Economic Analysis, Survey of Current Business (Washington, DC, August 1986). 1980: U.S. Department of Commerce, Bureau of Economic Analysis, Survey of Current Business (Washington, DC, October 1984).

United Kingdom, which raised the earnings of foreign parents in those countries. Their incentive to invest was enhanced by the continued growth of the U.S. economy, which increased the profitability of potential acquisition targets. In addition, some investment in 1994 may have been prompted by dollar depreciation against several major currencies." ${ }^{167}$ Large mergers and acquisitions in pharmaceuticals and telecommunications contributed noticeably to the growth in overall FDI in 1994. The largest FDI- related transaction in 1994 was British Telecommunications gain of a 20-percent ownership share of $\mathrm{MCI}$ Communications for $\$ 4.3$ billion. In a series of divestitures pursuant to restructuring, Eastman Kodak sold the over-the-counter drug unit of its Sterling Winthrop subsidiary to SmithKline Beecham (United Kingdom) for $\$ 2.9$ billion and the prescription drug unit of Sterling Winthrop to Elf Sanofi (France) for $\$ 1.7$ billion. Eastman Kodak also sold its L\&F Products subsidiary, a producer of household cleaners, to Reckitt and Colman of the United Kingdom for $\$ 1.6$ billion while SmithKline Beecham acquired Diversified Pharmaceutical Services for $\$ 2.3$ billion. Related to pharmaceuticals, but classified in the industry category of wholesale trade, was the Swedish drug company Astra's payment of $\$ 820$ million associated with its 50-percent share of the Astra-Merck U.S. joint venture. Other FDI-related transactions in the $\$ 1$ billionand-up range included the South African pulp and paper company Sappi Ltd.'s acquisition of S.D. Warren Company, a U.S. pulp and paper company, for $\$ 1.6$ billion and B.A.T. Industries' (United Kingdom) acquisition of American Tobacco Company for $\$ 1.0$ billion.

Investors in the United Kingdom again increased their country's share of overall FDI in the United States, making it the number one FDI investor in 1994 (Table 34). Japan remained in the number two position. Despite a generally stronger yen-dollar exchange rate, Japanese direct investment has slowed. In the 1990's, thus far, Japanese

${ }^{167}$ U.S. Department of Commerce, Bureau of Economics Analysis, Survey of Current Business (Washington, DC, June 1995), pp. 65-66. 


\section{Major FDI-Related Transactions in U.S. Energy 1994}

\section{Acquisitions}

Peabody Holding Co., the largest coal producer in the United States and subsidiary of the British conglomerate Hanson plc, purchased Carter Mining Co. from Exxon for $\$ 360$ million.

RTZ Corp. plc, through its wholly-owned U.S. subsidiary, Kennecott Corp, acquired Colowyo Coal from WR Grace for $\$ 233$ million.

Nova Corp., of Alberta, Canada, acquired a 36.5-percent equity interest in NGC Corp., owner of Natural Gas Clearinghouse, the largest independent gas marketing company in the United States, for $\$ 170$ million.

Kentucky-based CONSOL, a unit of the joint venture between DuPont and Germany's RWE, acquired Kentucky Criterion Coal Co. for $\$ 81$ million from Westmoreland Coal, another foreign affiliate.

\section{Divestitures}

Shell Oil Co. divested itself of its 25-percent interest in Zeigler Coal Holding Company. Proceeds from the divestment are estimated at $\$ 618$ million.

Bridge Oil Ltd. of Australia, including its subsidiary Bridge Oil (USA), was acquired by Parker \& Parsley Petroleum Company for a total value of $\$ 584$ million. About $\$ 152$ million of the acquisition was attributed to Australian and other foreign properties.

Italy's Agip Petroleum Co. received $\$ 195$ million for 17 onshore and offshore Gulf Coast properties from Occidental Petroleum.

The assets of Agip Coal Holding USA and Agip Coal America, both owned by ENI of Italy, were purchased by Catenary Coal Holdings, a part of Ashland Oil's Arch Mineral subsidiary, for \$150 million.

additions to FDI averaged $\$ 5$ billion annually, a considerable fall from an average of over $\$ 17$ billion in 1988 and 1989. In recent years, Japanese investors have been adversely affected by recession and slow economic growth, sagging corporate profits, and a banking system with continued liquidity problems.

The FDI position in petroleum was up 7 percent between 1993 and 1994 but remained well below its peak value of $\$ 42.9$ billion attained in 1990 (Table 31). Upstream profitability, which crashed following the oil price collapse of late 1985-early 1986, subsequently recovered and attained a post-collapse peak in the context of 1990's oil price run up. Since then, U.S. upstream profitability fell and stabilized at a low level (Table 5 in Chapter 2). In downstream operations, rates of return in U.S. refining and marketing peaked in the late 1980's following a massive consolidation of industry capacity. In subsequent years, profitability has declined sharply due to a combination of weak growth in petroleum product demand and added operating costs stemming from environmental requirements, particularly those related to the Clean Air Act Amendments of 1990.

Petroleum FDI is largely traceable to investors based in the Netherlands, primarily Royal Dutch/Shell, 100percent owner of Shell Oil, and in the United Kingdom, mainly British Petroleum and its BP America subsidiary. Most of the balance of European-based investment in U.S. petroleum largely reflects U.S. operations of France's two largest petroleum companies, Elf Aquitaine and Total, along with Belgium's Petrofina. Although Japan and Germany rank second and fifth, respectively, in terms of total FDI in the United States (Table 34), investors from these nations account for only a fraction of a percent of FDI in U.S. petroleum (Table 35).

Canadian investors' interest in U.S. petroleum and natural gas has shown a resurgence thus far in the 1990's. The Canadian share of petroleum-related FDI was 15 percent in 1980 but steadily declined to 3 percent in 1990 . A number of Canadian policies encouraged Canadians to 
Table 32. U.S. Capital and Exploratory Expenditures of Foreign-Affiliated Petroleum and Natural Gas Companies, 1993-1994 (Million Dollars)

\begin{tabular}{|c|c|c|c|c|c|}
\hline \multirow[b]{2}{*}{ Company } & \multicolumn{2}{|c|}{ Upstream $^{a}$} & \multirow[b]{2}{*}{ Company } & \multicolumn{2}{|c|}{ Downstream $^{\text {b }}$} \\
\hline & 1993 & 1994 & & 1993 & 1994 \\
\hline Shell Oil & 901 & 1,207 & Shell Oil & 704 & 1,087 \\
\hline BP America & 790 & 807 & Citgo Petroleum & 345 & 350 \\
\hline DuPont & 379 & 357 & BP America & 359 & 226 \\
\hline Anadarko Petroleum & 208 & 352 & Castle Energy & 36 & 218 \\
\hline Louis Dreyfus Natural Gas & 219 & 109 & Uno-Ven & 206 & 217 \\
\hline Santa Fe Energy Resources & 143 & 107 & Lyondell Petrochemical & 54 & 210 \\
\hline BHP Petroleum (Americas) . & 43 & 67 & DuPont $\ldots \ldots \ldots$ & 213 & 191 \\
\hline Fina $\ldots \ldots \ldots \ldots \ldots$ & 47 & 64 & Star Enterprise $\quad \ldots$ & 147 & 152 \\
\hline Canadian Occidental .......... & 41 & 47 & Clark USA & 68 & 100 \\
\hline Norcen Energy Resources & 141 & 43 & Total Petroleum, Ltd. & 234 & 95 \\
\hline Presidio Oil .... & 21 & 35 & Fina & 86 & 49 \\
\hline Chieftain Development International ..... & 21 & 22 & Tesoro Petroleum & 7 & NF \\
\hline Coho Energy ... & 24 & NF & & & \\
\hline Total $\ldots \ldots \ldots \ldots \ldots \ldots \ldots \ldots \ldots$ & 2,978 & 3,217 & Total $\ldots \ldots \ldots \ldots \ldots \ldots \ldots \ldots$ & 2,459 & 2,895 \\
\hline
\end{tabular}

${ }^{a}$ Oil and gas exploration, development, and production.

${ }^{b}$ Petroleum refining, marketing, and pipelines.

$\mathrm{NF}=$ Not foreign-affiliated in the year shown.

Sources: Company annual reports.

invest in their own energy resources in the 1980's, apparently at the expense of U.S. energy investments. Policies included the favoring of Canadian ownership of energy resources located in Canada, elimination of most energy price controls, and relaxation of restrictions on the export of Canadian natural gas. However, as the impacts of these measures receded, U.S. petroleum and natural gas became more attractive as targets of Canadian investors. Upstream, minority interests owned by Canadians in Santa Fe Energy Resources and continued growth in U.S. oil and gas production by Norcen Energy Resources and Chieftain International have added to Canadian investment. Toronto-based Horsham Corporation's acquisition of Clark USA Inc. increased Canadian investment in U.S. downstream operations. By 1994, the Canadian share of FDI in U.S. petroleum had increased to nearly 8 percent.

The U.S. Department of Commerce's classification procedures obscure the growth in foreign investors' interest in U.S. coal operations. ${ }^{168}$ In particular, the FDI position in U.S. coal declined from $\$ 1.4$ billion in 1991 to $\$ 0.6$ billion in 1994 (Table 31). Yet based on transactions data, mergers and acquisitions by foreign investors of U.S. coal assets averaged over $\$ 1$ billion annually over the same period (Table 30).

\section{Foreign-Affiliated Companies' Role in U.S. Energy Operations}

Transactions data and information drawn from the U.S. Department of Commerce's international investment surveys are useful in discerning the overall investment targets of foreign investors and the changing emphasis of their interest in U.S. energy. However, these data yield no information on the operational role of foreign-affiliated enterprises in U.S. energy activities in 1994 or over time.

\footnotetext{
${ }^{168}$ Three limitations of the U.S. Department of Commerce data can pose difficulties in assessing targets of investment among foreign investors. First, revisions of industry classifications of foreign-affiliated U.S. companies are made for only the most recent years. For example, in the data for 1993, revisions were made retroactive though 1991, as was the case for 1994 data. Consequently, the change in FDI position between 1990 and 1991 is, to some unknown extent, due solely to industry reclassifications. Second, the industry classifications of foreign-affiliated companies may ascribe significant energy investment activity to nonenergy industries. For example, the highly diversified Hanson p.l.c. acquired 100 percent of Peabody Holding Company (the leading producer of U.S. coal) in 1990 for $\$ 1.2$ billion. However, the effect on FDI of this acquisition appears to have been classified to an industry other than coal. Third, FDI measures net financial flows between parent and U.S. subsidiary, which can obscure the interpretation of FDI statistics. For example, a large repayment in the reporting year to a parent company of debt incurred in an earlier acquisition can reduce FDI even through FDI-related acquisition activity may have increased substantially in the reporting year.
} 
Table 33. Targets of Foreign Direct Investment in U.S. Industry, 1993-1994 (Billion Dollars)

\begin{tabular}{|c|c|c|c|}
\hline Industry & 1993 & 1994 & $\begin{array}{c}\text { Net Additions } \\
1994 \\
\end{array}$ \\
\hline Petroleum ........... & 31.7 & 34.0 & 2.3 \\
\hline \multicolumn{4}{|l|}{ Manufacturing } \\
\hline Food \& Kindred Products $\ldots \ldots \ldots \ldots \ldots \ldots \ldots \ldots \ldots$ & 23.0 & 20.9 & -2.1 \\
\hline 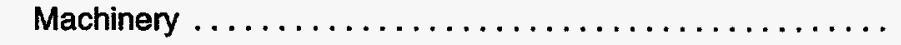 & 29.7 & 31.9 & 2.2 \\
\hline Other Manufacturing $\ldots \ldots \ldots \ldots \ldots \ldots \ldots \ldots \ldots \ldots \ldots \ldots$ & 43.4 & 50.1 & 6.7 \\
\hline \multicolumn{4}{|l|}{ Services } \\
\hline Wholesale Trade ..... & 60.6 & 65.8 & 5.2 \\
\hline$\ldots \ldots \ldots \ldots \ldots \ldots \ldots \ldots \ldots$ & 28.4 & 28.4 & 0.0 \\
\hline Other Services $\ldots \ldots \ldots \ldots \ldots \ldots \ldots \ldots \ldots \ldots \ldots$ & 34.8 & 36.5 & 1.7 \\
\hline Other Industries $\ldots \ldots \ldots \ldots \ldots \ldots \ldots$ & 21.7 & 28.6 & 7.0 \\
\hline
\end{tabular}

Note: Sum of components may not equal total due to independent rounding.

Source: U.S. Department of Commerce, Bureau of Economic Analysis, Survey of Current Business (Washington, DC, August 1995).

In this section, the involvement of foreign-affiliated companies in the areas of upstream and downstream petroleum operations (including natural gas production), coal production, and uranium exploration and development are reviewed. Overall, foreign affiliates' share of coal production increased by nearly 2 percentage points, natural gas was down a fraction of a percent, while refining capacity and oil production held steady (Figure 25).

\section{Oil and Gas Production and Reserves}

U.S. oil production of companies which were foreignaffiliated in both 1993 and 1994 was down 3 percent in 1994 (Table 36). The largest declines among foreign affiliates were registered by BP America and DuPont's Conoco unit. BP America's decline was traceable to a drop in production from Prudhoe Bay of 50 thousand barrels per day. ${ }^{169}$ Prudhoe Bay, located in Alaska's North
Slope, is a mature field with declining production. Recently, however, the rate of decline has been somewhat offset by natural gas reinjection projects. ${ }^{170}$ For DuPont, net sales of 61 million barrels of U.S. oil reserves in 1993 represented 14 percent of their U.S. oil reserves and accounted for most of the decline in their U.S. oil production. ${ }^{171}$

Although foreign affiliates' U.S. natural gas production was down 2 percent between 1993 and 1994, the decline was due to the exit of companies from the ranks of foreign-affiliated energy producers during $1994 .{ }^{172}$ For companies that were foreign-affiliated in both 1993 and 1994, natural gas production was up 2 percent, somewhat less than for the United States overall. In their 1994 annual reports to shareholders, three of the companiesDuPont, Norcen Energy Resources, and Shell Oilreported increased production from offshore fields in the Gulf of Mexico, while Anadarko Petroleum cited

\footnotetext{
${ }^{169}$ British Petroleum Company p.l.c., BP Financial and Operating Information 1990-1994, p. 34. p. 45.

${ }^{170}$ Energy Information Administration, Performance Profiles of Major Energy Producers 1994, DOE/EIA-0206(94) (Washington, DC, February 1996),

${ }^{171}$ E.I. DuPont de Nemours and Company, DuPont Data Book 1994, p. 42.

${ }^{172}$ Natural gas producers who were no longer foreign-affiliated in 1994 and foreign affiliates who exited the industry include Bridge Oil (USA), Coho Energy, HarCor Energy, Reading \& Bates, Tesoro Petroleum, and Zapata.
} 
Table 34. Geographic Sources of Foreign Direct Investment in U.S. Industry, 1993-1994 (Billion Dollars)

\begin{tabular}{|c|c|c|c|}
\hline \multirow[b]{2}{*}{ Region } & \multicolumn{2}{|c|}{ Foreign Direct Investment Position } & \multirow{2}{*}{$\begin{array}{c}\text { Net Additions } \\
1994 \\
\end{array}$} \\
\hline & 1993 & 1994 & \\
\hline 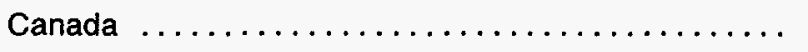 & 40.1 & 43.2 & 3.1 \\
\hline Netheriands $\ldots \ldots \ldots \ldots \ldots \ldots \ldots \ldots \ldots$ & 72.2 & 70.6 & -1.5 \\
\hline 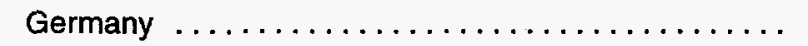 & 34.8 & 39.6 & 4.7 \\
\hline France $\ldots \ldots \ldots \ldots \ldots \ldots \ldots \ldots \ldots$ & 29.4 & 33.5 & 4.1 \\
\hline$\ldots \ldots \ldots \ldots \ldots \ldots$ & 22.2 & 25.3 & 3.1 \\
\hline Other Europe . . . . . . . . . . . . . . . . . . & 26.1 & 30.4 & 4.3 \\
\hline 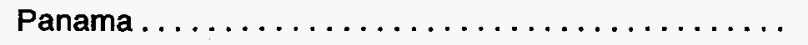 & 4.0 & 3.6 & -0.3 \\
\hline Venezuela $\ldots \ldots \ldots \ldots \ldots \ldots \ldots \ldots \ldots$ & -0.3 & -0.3 & 0.1 \\
\hline Other Latin America $\ldots \ldots \ldots \ldots \ldots \ldots \ldots \ldots$ & 9.0 & 12.3 & 3.3 \\
\hline 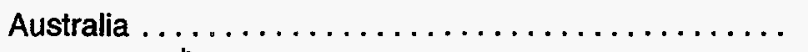 & 6.3 & 7.9 & 1.6 \\
\hline$\ldots \ldots \ldots \ldots \ldots \ldots \ldots$ & 3.4 & 3.5 & -0.1 \\
\hline 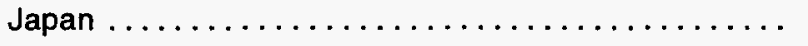 & 99.2 & 103.1 & 3.9 \\
\hline Other Countries $\ldots \ldots \ldots \ldots \ldots \ldots \ldots \ldots$ & 7.8 & 9.8 & 1.9 \\
\hline
\end{tabular}

atatin America includes South America, Central America, and the Caribbean (outside of U.S. possessions and territories).

${ }^{b} O P E C$ is the Organization of Petroleum Exporting Countries. Its members are Algeria, Ecuador, Gabon, Indonesia, Iraq, Kuwait, Libya, Nigeria, Qatar, Saudi Arabia, the United Arab Emirates, and Venezuela.

Note: Sum of components may not equal total due to independent rounding.

Source: U.S. Department of Commerce, Bureau of Economic Analysis, Survey of Current Business (Washington, DC, August 1995).

Kansas and the Texas Panhandle as sources of increased natural gas production.

Changes in foreign affiliates' U.S. oil and gas reserves followed patterns which were similar to those of production (Table 36 and Table 37). Most of the decline in foreign affiliates' U.S. oil reserves can be attributed to Shell Oil's falloff in extensions and discoveries, from 251 million barrels in 1993 to 85 million barrels in 1994. However, Shell's exploration and development performance in 1993 was exceptional, far exceeding its average extensions and discoveries of 30 million barrels of oil per year in the 1990-1992 span. Shell Oil's U.S. natural gas reserves increased by 635 billion cubic feet in 1994,reflecting 1,200 billion cubic feet added through extensions and discoveries, up from their annual average extensions and discoveries of 400 billion cubic feet in 1990-1993. Offshore locales played an important role in adding to reserves. According to Shell Oil's chief executive officer, "In 1994, we ... continued ... successfully exploring for and bringing on new oil and gas volumes, particularly in the Gulf of Mexico."173 Anadarko Petroleum, who also increased their U.S. oil and gas reserves between 1993 and 1994, reported, "We made large oil discoveries in [Algeria and] the Gulf of Mexico. We installed two production platforms in the Gulf of Mexico."174

\footnotetext{
${ }^{173}$ Shell Oil Company, 1994 Annual Report, p. 2.

${ }^{174}$ Anadarko Petroleum Corp., 1994 Annual Report, p. 2.
} 
Table 35. Geographic Sources of Foreign Direct Investment in U.S. Petroleum, 1993-1994 (Million Dollars)

\begin{tabular}{|c|c|c|c|}
\hline \multirow[b]{2}{*}{ Source } & \multicolumn{2}{|c|}{ Foreign Direct Investment } & \multirow{2}{*}{$\begin{array}{c}\text { Net Additions } \\
1994 \\
\end{array}$} \\
\hline & 1993 & 1994 & \\
\hline All Countries....... . & 31,740 & 34,048 & 2,308 \\
\hline Canada $\ldots . . . \ldots \ldots \ldots$ & 2,455 & 2,585 & 130 \\
\hline \multicolumn{4}{|l|}{ Europe } \\
\hline United Kingdom & 9,963 & 10,906 & 943 \\
\hline Netherlands $\ldots \ldots \ldots \ldots \ldots \ldots \ldots \ldots \ldots \ldots \ldots \ldots$ & 12,067 & 12,770 & 3 \\
\hline Germany $\ldots \ldots \ldots \ldots \ldots \ldots \ldots \ldots \ldots \ldots \ldots \ldots$ & $(b)$ & 118 & (b) \\
\hline Other Europe $\ldots \ldots$. & $\left({ }^{b}\right)$ & 2,024 & (b) \\
\hline \multicolumn{4}{|l|}{ Latin America $^{a}$} \\
\hline Netherlands Antilles & 1,609 & 1,690 & 81 \\
\hline Venezuela .......... & (b) & -572 & (b) \\
\hline Other Latin America ... & (b) & 193 & $($ b) \\
\hline$\ldots \ldots \ldots \ldots \ldots \ldots \ldots \ldots \ldots$ & 1,539 & $\left({ }^{b}\right)$ & $($ (b) \\
\hline Other OPEC ${ }^{\circ}$ & $\left({ }^{b}\right)$ & 1,585 & (b) \\
\hline Japan $. . . \ldots \ldots \ldots .$. & 359 & 275 & -84 \\
\hline Other Countries $\ldots \ldots \ldots \ldots \ldots \ldots \ldots \ldots \ldots \ldots \ldots$ & (b) & (b) & (b) \\
\hline
\end{tabular}

a'Latin America includes South America, Central America, and the Caribbean (outside of U.S. possessions and territories).

bata withheld by the U.S. Department of Commerce to prevent disclosure.

${ }^{\circ} \mathrm{OPEC}$ is the Organization of Petroleum Exporting Countries. Its members are Algeria, Ecuador, Gabon, Indonesia, Iran, Iraq, Kuwait, Libya, Nigeria, Qatar, Saudi Arabia, the United Arab Emirates, and Venezuela.

Source: U.S Department of Commerce, Bureau of Economic Analysis, Survey of Current Business (Washington, DC, August 1995).

\section{Refining and Gasoline Marketing}

Foreign-affiliated companies' share of U.S. crude distillation capacity, at 29 percent, was down a fraction of a percent between 1993 and 1994 (Table 38). The reduction in foreign ownership of Tesoro Petroleum below the threshold of a 10-percent equity share accounted for this decline. Excluding Tesoro, foreign affiliates added 118 thousand barrels per day of refining capacity, a rise of 3 percent, which about matched the growth in capacity for the United States as a whole. Over one-half of the foreign affiliates' capacity additions were in Illinois and Ohio with BP America, Castle Energy, Clark USA, and Shell Oil reporting expansions in these States. Fina's addition of 31 thousand barrels per day of crude distillation capacity to their Port Arthur, Texas, refinery was the largest single expansion by a foreign affiliate in 1994.

The role of foreign affiliates in U.S. gasoline marketing, as measured by their share of retail outlets selling gasoline, rose from 26 percent in 1993 to 27 percent in 1994. (Table
39). The increased share for foreign affiliates reflected a drop in the total number of retail outlets in the United States rather than an expansion in the number of outlets supplied by them. ${ }^{175}$ The number of foreign-affiliated retail gasoline outlets held fairly steady as an expansion in Citgo's jobber-supplied network was offset by a contraction in Total Petroleum's marketing network and Tesoro Petroleum's shedding of their foreign affiliation status. Similarly, the volume of gasoline supplied in the United States by foreign-affiliated companies changed little between 1993 and 1994. Increased gasoline sales of Shell Oil and Citgo were offset by BP America's reduced gasoline sales stemming from their divestiture of their West Coast refining/marketing operations in December 1993 and Tesoro Petroleum's exit from the ranks of the foreign affiliates in $1994 .{ }^{176}$

\section{Coal Production}

U.S. coal operations returned to normal conditions in 1994, following an extended work stoppage by the United

\footnotetext{
${ }^{175}$ Circle $\mathrm{K}$ was mistakenly omitted as a foreign affiliate in the 1993 edition of this report. Circle K became foreign-affiliated in July, 1993 when CK Acquisitions, a unit of Bahranian-owned Investcorp, purchased the company for $\$ 399.5$ million.

${ }^{176}$ British Petroleum Company p.l.c., BP Financial and Operating Information 1990-1994, p. 40; Citgo Petroleum Corporation, 1994 Annual Report, p. 66; and Tesoro Petroleum Corporation, 1994 Securities and Exchange Commission Form 10-K, p. 4.
} 
Figure 25. Foreign Affiliates' Share of U.S. Production of Oil, Gas, and Coal, and of U.S. Refining Capacity, 1980-1994

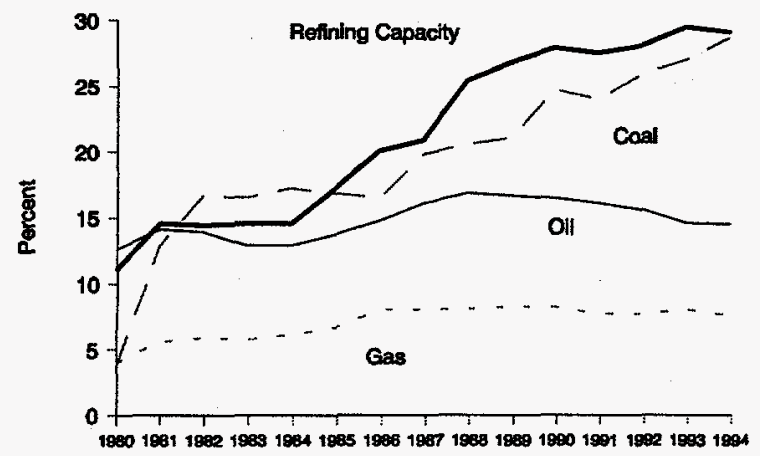

Sources: Tables $7,9,10$, and 11 of Chapter 4 of this report. U.S. Department of Energy, Annual Report to Congress, DOE/S-0010(84) (Washington, DC, September 1984). Energy Information Administration, Profiles of Foreign Direct Investment in U.S. Energy, 1983-1992, DOE/EIA-0466 (Washington, DC, 1984-1994).

Mine Workers of America during 1993. The strong growth in U.S. coal production in 1994, up 9 percent from 1993 (Table 40), largely served to replenish coal consumers' stocks, which were at an 18-year low at the end of 1993. Coal production of foreign affiliates grew by 16 percent between 1993 and 1994, resuming an upward trend in production (Figure 26). However, excluding Zeigler Coal, which ceased to be foreign-affiliated after Shell Oil sold its 25-percent stake in Zeigler, foreign affiliates' coal production was up 36 percent. In fact, growth in production for the three largest coal-producing foreign affiliates equaled 88 percent of the growth in annual U.S. coal production between 1993 and 1994.

The sources of growth in foreign affiliates' production stemmed from their recovery from the 1993 work stoppage and recent acquisitions of other coal producers. The companies most affected by the strike operated primarily east of the Mississippi and were disproportionately foreign-affiliated. The largest U.S. coal producer, Peabody Holding Company, is owned by UKbased Hanson plc. Peabody increased its low-sulfur coal production capability through its acquisitions of Western coal operations from Santa Fe Pacific in 1993 and Exxon in 1994. According to Hanson, "In fiscal 1995, Peabody's coal production is expected to increase by approximately
$50 \% .^{\prime \prime 177}$ Consol Energy, a joint venture between DuPont's Conoco unit and Germany's Rheinbraun AG, realized a 55-percent increase in production in large part through their acquisition of Island Creek Coal from Occidental Petroleum in 1993. Kennecott Energy, owned by UKbased RTZ plc, upped its U.S. coal production in 1994 through mines gained in its acquisitions of Nerco and Sun Company's Cordero Mining Company in 1993. Also, Kennecott increased its coal production in 1994 due to an absence of work stoppages and to strong demand by utilities for low-sulfur coal. ${ }^{178}$

\section{Uranium Exploration and Development Expenditures}

The U.S. uranium industry remained in a depressed state in 1994. For the years 1992-1994, U.S. uranium production averaged only a quarter of the level of the prior three-year period. ${ }^{179}$ Accordingly, activity and expenditures for uranium exploration and development in the United States plunged in recent years. For example, total U.S. exploration and development expenditures fell nearly 68 percent from 1993 to 1994 , to $\$ 3.7$ million, following sizable declines in 1992 and 1993 (Table 41). Foreign affiliates' expenditures fell more steeply, by 78 percent, to $\$ 1.9$ million. Still, foreign affiliates accounted for over 50 percent of total U.S. uranium exploration and development expenditures in 1994.

\section{Financial Performance of Foreign-Affiliated Energy Companies}

Despite strong economic growth in the United States and most areas outside the Former Soviet Union, 1994 was generally not a good year for petroleum and natural gas producers and processors. In upstream operations, both oil and natural gas prices were down as was U.S. oil production. Increased natural gas production, up 2 percent between 1993 and 1994, was not sufficient to offset the financial impacts of these developments. Downstream, a sharp falloff in refining margins (the spread between product prices received by refiners and crude oil input prices paid by refiners) in the latter nine months of 1994 resulted in a deterioration in financial results for refiners. In contrast, U.S. coal markets yielded improved financial results in 1994, as the coal industry recovered from the effects of sizable work stoppages in the prior year, with a 9-percent increase in production

\footnotetext{
${ }^{177}$ Hanson, p.1.c., Annual Report 1994.

${ }^{178}$ The RTZ Corporation p.1.c., Annual Reports and Accounts 1994, p. 20.

${ }^{179}$ Energy Information Administration, Uranium Industry Annual 1994, DOE/EIA-0478(94) (Washington, DC, July 1995), p. xviii.
} 
Table 36. Net Production of Petroleum and Dry Natural Gas in the United States by Foreign-Affiliated U.S. Companies, 1993-1994

\begin{tabular}{|c|c|c|c|c|}
\hline \multirow[b]{2}{*}{ Company } & \multicolumn{2}{|c|}{$\begin{array}{l}\text { Crude Oil and Natural Gas Liquids } \\
\text { (thousand barrels per day) }\end{array}$} & \multicolumn{2}{|c|}{$\begin{array}{l}\text { Dry Natural Gas } \\
\text { (billion cubic feet) }\end{array}$} \\
\hline & 1993 & 1994 & 1993 & 1994 \\
\hline BP America & 627.7 & 604.9 & $\mathrm{~b}_{33.0}$ & $\mathrm{~b}_{25.2}$ \\
\hline Shell Oil Co $\ldots . . . . . . . . . . . . . . . . . .$. & 402.7 & 413.7 & 539.0 & 570.0 \\
\hline DuPont $\ldots \ldots \ldots \ldots \ldots \ldots \ldots \ldots \ldots \ldots$ & 109.6 & 90.4 & 305.0 & 318.0 \\
\hline Santa Fe Energy Resources & 60.0 & 57.5 & 60.3 & 49.8 \\
\hline Anadarko Petroleum ...... & 26.8 & 31.0 & 159.0 & 173.0 \\
\hline Fina $\ldots \ldots \ldots \ldots \ldots \ldots$ & 16.2 & 12.5 & 67.9 & 52.9 \\
\hline Canadian Occidental Ltd. ............. & 7.7 & 9.3 & 21.0 & 20.0 \\
\hline Total Minatome Corp $\ldots \ldots \ldots \ldots \ldots \ldots$ & 8.8 & 7.7 & 37.6 & 28.2 \\
\hline BHP Petroleum (Americas) $\ldots \ldots \ldots \ldots \ldots$ & 6.8 & 5.7 & 34.7 & 31.0 \\
\hline Louis Dreyfus Natural Gas Co. .......... & 5.8 & 5.1 & 30.5 & 43.1 \\
\hline Norcen Energy Resources $\ldots \ldots \ldots \ldots \ldots$ & 3.3 & 4.7 & 19.8 & 32.5 \\
\hline Elf Aquitaine Inc. $\ldots \ldots \ldots \ldots \ldots \ldots \ldots$ & 4.6 & 4.1 & 23.4 & 22.6 \\
\hline Presidio Oil Co. ..................... & 3.9 & 3.1 & 15.3 & 17.2 \\
\hline Coho Energy $\ldots \ldots \ldots \ldots \ldots \ldots \ldots$ & 5.0 & NF & 0.5 & NF \\
\hline Chieftain Development International ...... & 1.8 & 1.9 & 17.6 & 12.6 \\
\hline Saba Petroleum Co. $\ldots \ldots \ldots \ldots \ldots \ldots$ & 1.6 & 1.8 & 1.1 & 1.0 \\
\hline Bridge Oil (USA) & 3.0 & 0.0 & 33.6 & 0.0 \\
\hline Other Companies ..... & 3.6 & 3.2 & 52.6 & 21.7 \\
\hline Total Foreign-Affiliated . . & $1,298.9$ & $1,256.6$ & $1,451,4$ & $1,418.8$ \\
\hline Total United States ...... & $8,836.0$ & $8,645.0$ & $18,095.0$ & $18,747.0$ \\
\hline Percent Foreign-Affiliated & 14.7 & 14.5 & 8.0 & 7.6 \\
\hline
\end{tabular}

aunless otherwise noted, company production is net ownership interest production.

${ }^{b}$ Excludes natural gas consumed in Alaskan operations.

$\mathrm{NF}=$ No foreign affiliation during this period.

Note: Totals may not equal sum of components due to independent rounding.

Sources: Company data: Form 10-K reports to the U.S. Securities and Exchange Commission and Annual Reports to Shareholders. United States totals: Energy Information Administration, Monthly Energy Review, DOE/EIA-0035(96/01) (Washington, DC, January 1996).

Table 42 presents financial results for foreign-affiliated U.S. energy companies and a comparison group composed of other U.S.-based companies with primary lines of business in coal production, oil and natural gas production, or petroleum refining. The overall effects of U.S. energy market developments in 1994 are apparent in the results for this latter group of nearly 300 companies.

Their net income declined 11 percent, cash flow from operations fell 6 percent, and the companies reduced their capital expenditures (including mergers and acquisitions) by 13 percent. In contrast, although the foreign affiliates' cash flow and capital expenditures also declined, their net income more than doubled, from \$1.9 billion in 1993 to $\$ 4.6$ billion in 1994. However, most of this increase was due to performance in nonenergy operations and the effects of unusual items ${ }^{180}$ on net income. In particular, among the foreign affiliates registering the largest increases in net income between 1993 and 1994:

- DuPont reported a gain in net income of $\$ 2.2$ billion. About 45 percent of the gain was attributable to the absence of unusual items in 1994 and most of the remainder came from chemicals and other

\footnotetext{
${ }^{180}$ Unusual items are composed of gains and charges recognized in a company's income statement that are of a non-recurring nature and generally unrelated to current operations. These items include effects of accounting changes, litigation settlements, gains and losses from large divestitures of assets, provisions for the cost of restructuring, and provisions of reserves for future liabilities.
} 
Table 37. Domestic Oil and Dry Natural Gas Proved Reserves and Production for Foreign-Affiliated U.S. Companies, 1993 and 1994

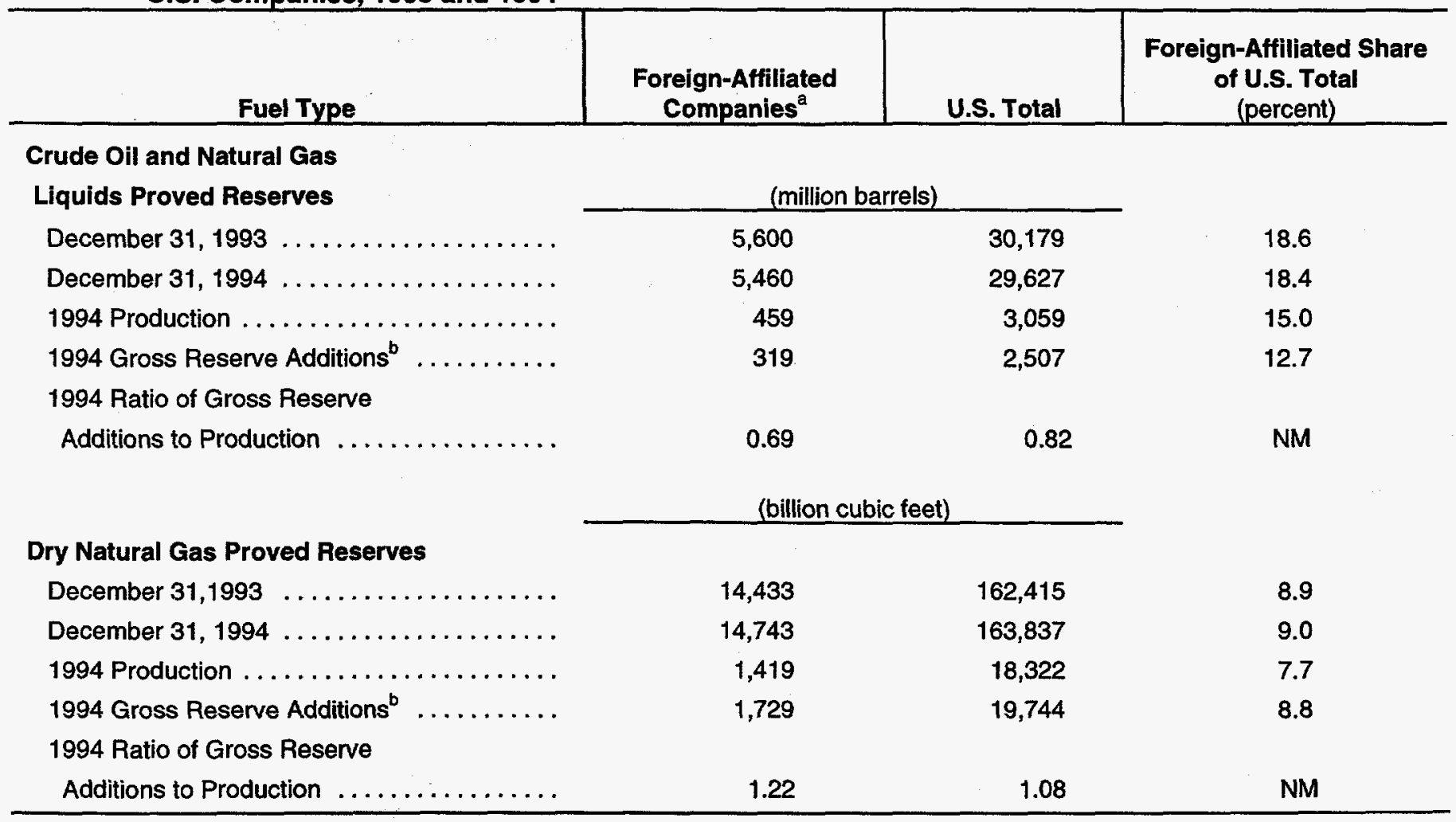

${ }^{a}$ Reserves and production are on a net ownership interest basis. The reserves and production data under each fuel type are for companies identified as foreign affiliated and reporting oil and/or natural gas production during 1994

${ }^{b}$ Gross reserve additions = annual change in reserves + annual production.

NM= Not meaningful.

Sources: Foreign-affiliated data: Companies' Form 10-K filed with the U.S. Securities and Exchange Commission and annual reports to shareholders. U.S. totals: Energy Information Administration, U.S. Crude Oil, Natural Gas, and Natural Gas Liquids Reserves 1994 Annual Report, DOE/EIA-0216(94) (Washington, DC, October 1995).

nonenergy businesses. Income from petroleum operations in 1994 was down from 1993 income. ${ }^{181}$

- Lyondell Petrochemical attributed their $\$ 197$ million increase in net income to higher margins in their petrochemical operations. Income from petroleum refining was down due to lower margins and higher operating expenses. ${ }^{182}$

- Another foreign affiliate with U.S. refining operations, Toronto-based Horsham Corp. (100percent owner of Clark USA), registered a \$139 million gain in net income. This gain was due largely to improved results at a gold-mining sub- sidiary and the bottom-line effects of a stock issue by this subsidiary. ${ }^{183}$ Net income (excluding unusual items) at Clark USA deteriorated due to poor refining margins.

- Schlumberger Ltd., a worldwide oilfield services and measurement equipment company incorporated in the Netherlands, derives about a quarter of its revenue in the United States. All of Schlumberger's $\$ 201$ million increase in net income in 1994 can be attributed to the absence of the effects of an accounting change implemented in 1993 . Among energy-related operations, oilfield services posted a 6-percent increase in income due to an improvement in North American drilling activity. ${ }^{184}$

\footnotetext{
${ }^{181}$ E.I. DuPont de Nemours and Company, DuPont Data Book 1994, pp. 54-55.

${ }^{182}$ Lyondell Petrochemical, 1994 Annual Report, pp. 9, 20-22.

${ }^{183}$ Horsham Corporation, 1994 Annual Report, Note 13.

${ }^{184}$ Schlumberger Ltd., 1994 Annual Report to Stockholders, p. 16.
} 
Table 38. U.S. Refinery Operations of Foreign-Affiliated U.S. Companies, 1993-1994

\begin{tabular}{|c|c|c|c|c|}
\hline \multirow[b]{2}{*}{ Company } & \multicolumn{2}{|c|}{ Number of Refineries ${ }^{a}$} & \multicolumn{2}{|c|}{$\begin{array}{c}\text { Total Crude Distillation Capacity } \\
\text { (thousand barrels per day) }\end{array}$} \\
\hline & 1993 & 1994 & 1993 & 1994 \\
\hline Shell Oil Co. ..... & 5 & 5 & 739 . & 761 \\
\hline BP America $\ldots \ldots \ldots \ldots \ldots$ & 4 & 4 & 666 & 701 \\
\hline Star Enterprise $\ldots \ldots \ldots \ldots$ & 3 & 3 & 600 & 600 \\
\hline Petroleos de Venezuela ..... & 4 & 4 & 503 & 503 \\
\hline DuPont..$\ldots \ldots \ldots \ldots \ldots$ & 4 & 4 & 429 & 438 \\
\hline Lyondell Petrochemical Co. .. & 1 & 1 & 265 & 265 \\
\hline Fina $\ldots \ldots \ldots \ldots \ldots \ldots$ & 2 & 2 & 199 & 230 \\
\hline Shell Oil/PMI Holdings....... & 1 & 1 & 216 & 216 \\
\hline Total Petroleum, Ltd. ........ & 4 & 4 & 198 & 198 \\
\hline Uno-Ven ................. & 1 & 1 & 147 & 147 \\
\hline Clark USA $\ldots \ldots \ldots \ldots \ldots$ & 2 & 2 & 129 & 143 \\
\hline Castle Energy $\ldots \ldots \ldots \ldots$ & 2 & 2 & 120 & 127 \\
\hline \multicolumn{5}{|l|}{ BHP-Petroleum } \\
\hline Americas Refining Inc. ...... & 1 & 1 & 94 & 94 \\
\hline Tesoro Petroleum ......... & 1 & NF & 72 & NF \\
\hline Pacific Refining $\ldots \ldots \ldots \ldots$ & 1 & 1 & 50 & 50 \\
\hline Transworld Oil USA ......... & 1 & 1 & 13 & 13 \\
\hline Total Foreign-Affiliated ...... & 37 & 36 & 4,440 & 4,486 \\
\hline Total United States . ....... & 179 & 175 & 15,034 & 15,434 \\
\hline Percent Foreign-Affiliated .... & 20.7 & 20.6 & 29.5 & 29.1 \\
\hline
\end{tabular}

${ }^{a}$ Refineries operable as of December 31 st in each year.

$\mathrm{NF}=$ No foreign affiliation during this period.

Sources: Energy Information Administration, Petroleum Supply Annual, DOE/EIA-0340 (Washington, DC), 1993-1994.

The coal operations of companies that were adversely affected by the work stoppage of 1993 were an exception to the generally unimpressive financial performance of energy operations in 1994. Four of the five companies that bore the brunt of the selective strike in 1993 were foreign affiliates: Peabody Holding Company, Zeigler Coal Holding Company (not foreign-affiliated in 1994), Ashland Coal, and Consol Energy. ${ }^{185}$ The first three of the strike-affected affiliates in total reported a \$300-millionplus increase in income from coal operations in $1994{ }^{186}$

\section{Outward Investment in Petroleum}

Investment flows out of the United States as well as into the United States. Direct investment abroad (DIA), reported by the U.S. Department of Commerce, is the value of U.S. parent companies' net equity in and loans to affiliates outside the United States. The Commerce data show that the DIA position in foreign petroleum (which includes natural gas extraction) did not grow between 1982 and 1992 but the DIA position for other industries tripled (Table 43). As a result, the share of DIA for petroleum operations fell from a peak of 28 percent in 1982-1984 to 12 percent in 1992. Although DIA in petroleum rose in 1993 and 1994, this growth was outpaced by growth in DIA in other industries.

The DIA data appear to understate the attractiveness of foreign petroleum as a target of investment for U.S. companies. For example, in 1993 and 1994, petroleum operations accounted for 30 percent of U.S.-based

\footnotetext{
${ }^{185}$ Energy Information Administration, Coal Industry Annual 1993, DOE/EIA-0584(93) (Washington, DC, December 1994), p. xi.

${ }^{186}$ The impact of the strike on Consol could not be assessed. DuPont reports the financial results for its 50-percent owned Consol joint venture as an unconsolidated subsidiary. For all of its unconsolidated subsidiaries, which includes Consol and DuPont Merck Pharmaceutical Company, DuPont reported net income of $\$ 121$ million in 1993 and $\$ 361$ million in 1994.
} 
Table 39. Branded Retail Outlets and Total Gasoline Supplied by Foreign-Affiliated U.S. Companies, 1993-1994

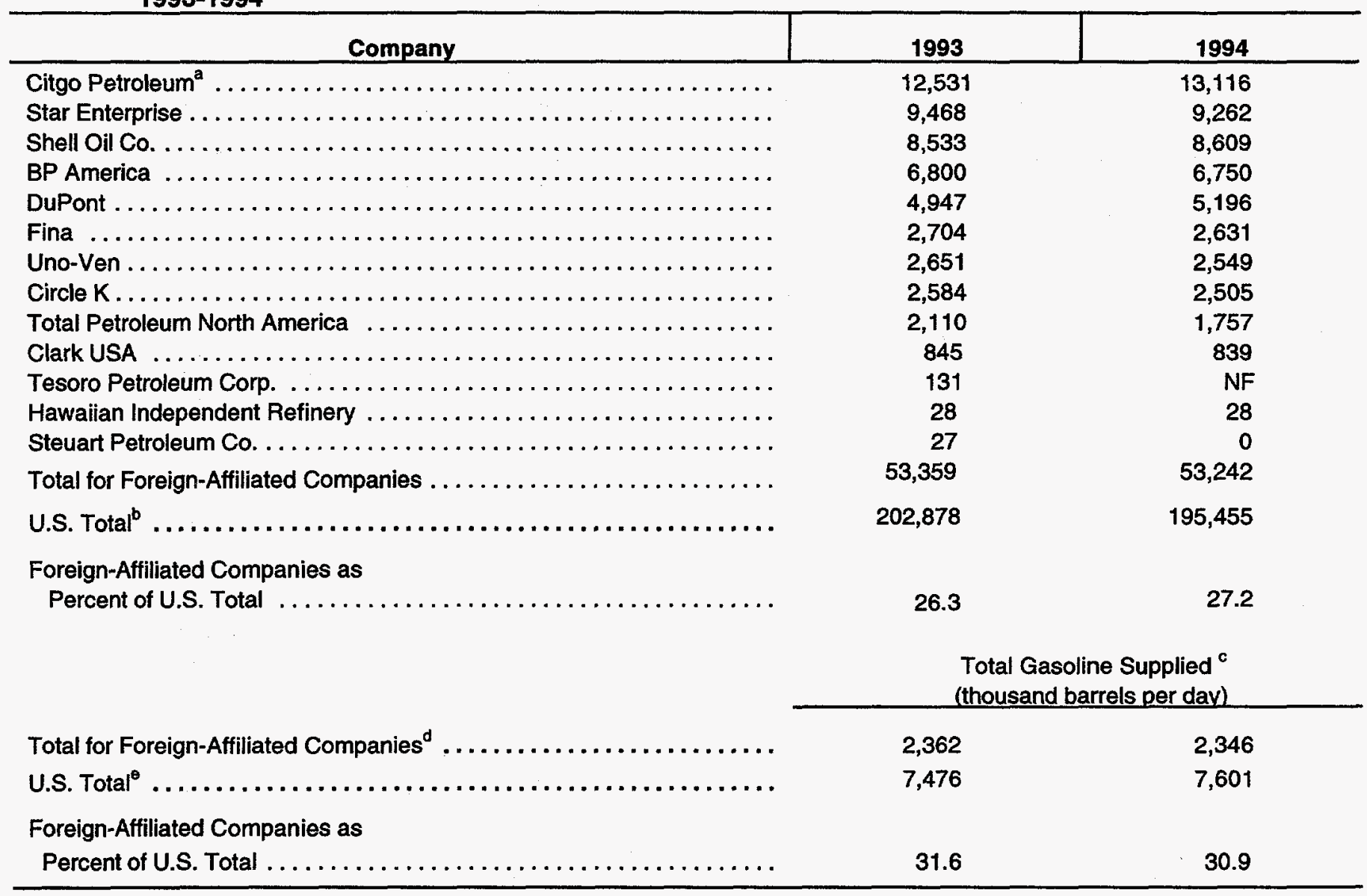

\footnotetext{
a Jobber-supplied outlets. Citgo is 100 -percent owned by Petroleos de Venezuela.

The total includes all establishments selling gasoline at retail.

'Gasoline Supplied refers to average daily gasoline shipments.

dDisaggregated company numbers are considered proprietary by the Energy Information Administration.

Total gasoline supplied.

NF = No foreign affiliation during this period.
}

Sources: Company station counts and total branded outlets: National Petroleum News Market Facts, 1995. Company gasoline volumes: Energy Information Administration, Form ElA-782c. Total gasoline supplied: Energy Information Administration, Monthly Energy Review, DOE/EIA-0035(96/01) (Washington, DC, January 1996).

companies' planned foreign capital expenditures (including exploration expenses). ${ }^{187}$ Since the FRS companies account for over 90 percent of total foreign petroleum capital expenditures, ${ }^{188}$ examination of their spending patterns should indicate the main investment targets in foreign petroleum of U.S. companies.
Following the oil price collapse of late 1985 and the first half of 1986, the FRS companies' foreign upstream (oil and gas exploration, development, and production) expenditures doubled by 1989 (Figure 27). Expenditures for U.S. upstream operations were, by contrast, only half the level of 1985 's expenditures. A variety of factors contributed to

\footnotetext{
${ }^{187}$ U.S. Department of Commerce, Bureau of Economic Analysis, Survey of Current Business (Washington, DC, March 1994 ), pp. 36-43.

${ }^{188}$ In 1992, the latest year for which the U.S. Department of Commerce published actual capital expenditures (including exploration expenditures) by majority-owned foreign affiliates, expenditures for petroleum outside the United States totaled $\$ 18.4$ billion. In 1992, the comparable expenditures for the FRS companies totaled \$17.5 billion. See U.S. Department of Commerce, Bureau of Economic Analysis, Survey of Current Business (Washington, DC, March 1994), p. 37; and Energy Information Administration, Performance Profiles of Major Energy Producers 1992, DOE/EIA-0206(Washington, DC, January 1994), Tables B11 and B22.
} 
Table 40. Bituminous Coal and Lignite Production and Source of Ownership of Foreign-Affiliated Coal Companies in the United States, 1993-1994 (Thousand Short Tons)

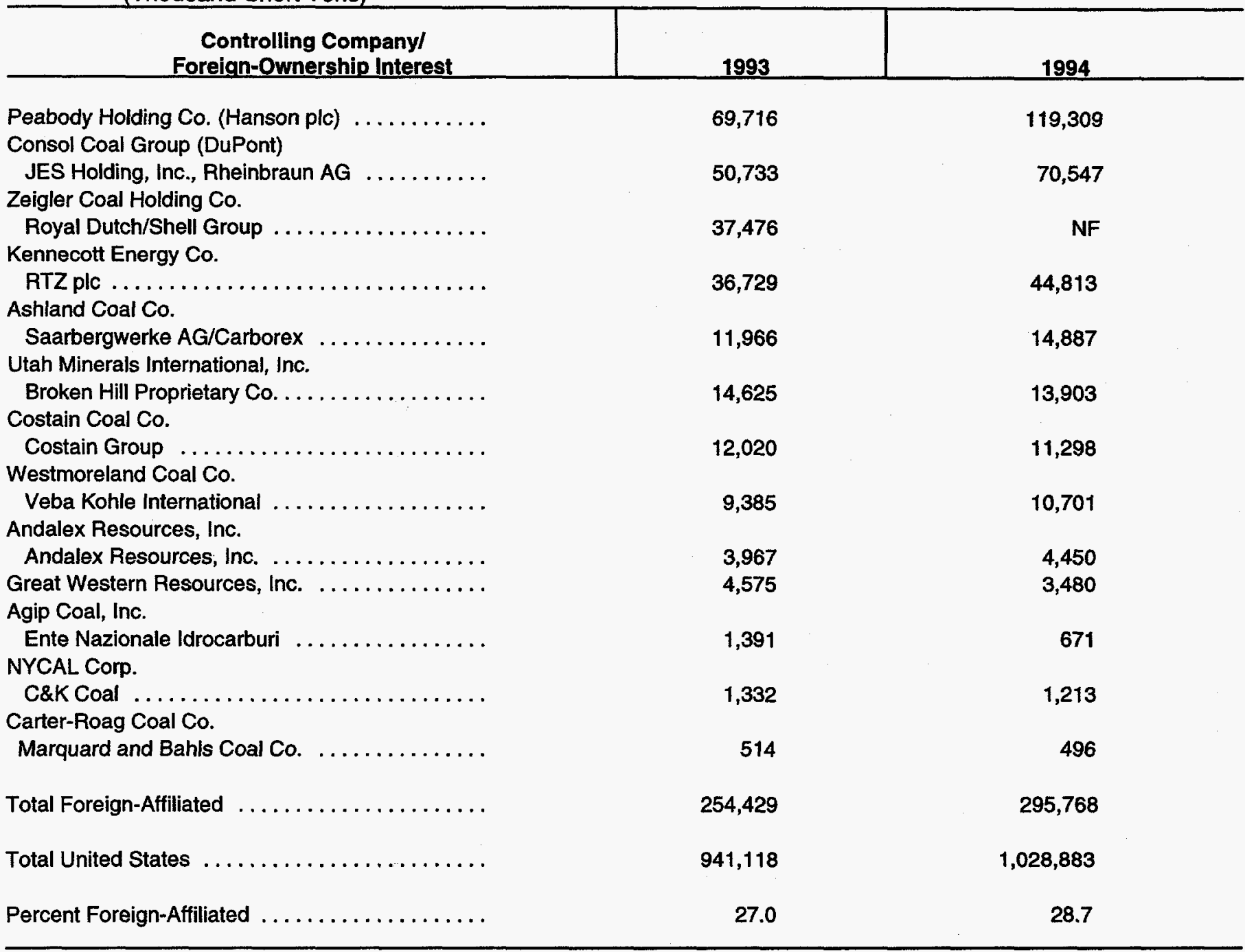

${ }^{a}$ Coal production refers to bituminous coal, subbituminous coal, and lignite coal production only.

NF=No foreign affiliation during this period.

Source: Energy Intormation Administration, Coal Industry Annual 1993, DOE/EIA-0584(93) (Washington, DC, December 1994; and Energy Information Administration, Coal Industry Annual 1994, DOE/EIA-0584(94) (Washington, DC, October 1995).

this shift in upstream activity to foreign locales. These factors, which have been reviewed in detail in prior editions of this report, ${ }^{189}$ include the interactions of costs, geology, development of natural gas markets, regulations, and tax policies. All regions registered higher expenditures in the latter half of the 1980's. The largest gains were in Europe, the other Eastern Hemisphere, and Canada (Figure 28). In the 1990's, foreign upstream expenditures of the FRS companies have declined slightly. Most of the decline resulted from the completion of a number of projects to increase the recovery of North Sea reserves and increase the reliability and safety of North Sea production facilities. Also, in nearly all regions, the FRS companies reduced their expenditures for exploration but emphasized the development of previously discovered fields.

\footnotetext{
${ }^{189}$ See the 1991 and 1993 editions of this report.
} 
Figure 26. Production and Share of U.S. Total Bituminous Coal and Lignite for ForeignAffilliated U.S. Companies, 1980-1994

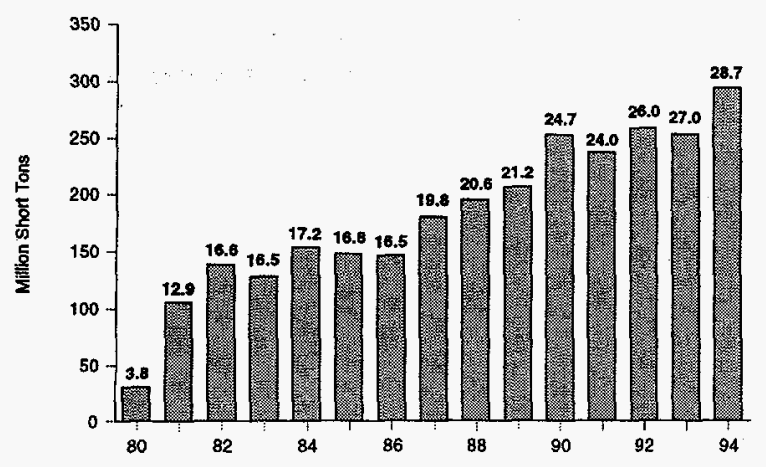

Note: Percentage values appearing above bars indicate foreignaffiliates; share of U.S. production.

Sources: 1981: Energy Information Administration, Profiles of Foreign Direct Investment in U.S. Energy 1983, DOE/EIA-0466 (Washington, DC, February 1985). 1982-1989: Keystone Coal Industry Manual, 1983-1990 Editions. 1990: 1992 Coal Mine Directory, (Chicago, IL: Maclean Hunter Publishing Co., October 1991). 1991: 1993 Coal Mine Directory (Chicago, IL: Maclean Hunter Publishing Co., January 1993). 1992: 1994 Coal Mine Directory (Chicago, IL: Maclean Hunter Publishing Co., January 1994). 1993: 1995 Coal Mine Directory (Chicago, IL: Maclean Hunter Publishing Co., January 1995). U.S. Totals: Energy Information Administration, Coal Industry Annual 1993, DOE/EIA-0584(93) (Washington, DC, December 1994).

The FRS companies' capital expenditures for foreign downstream petroleum (refining, marketing, and transport, including tankers) displayed a similar pattern, nearly doubling between 1986 and 1991 (Figure 27). In the 1990's, foreign downstream expenditures declined slightly but remained at historically high levels. The Far East has been the focus of foreign refinery expansion of the FRS companies in recent years. Over the 1990-1994 period, the FRS companies expanded their refining capacity in the Far East by 18 percent, while increasing their European capacity only marginally. ${ }^{190}$ Nevertheless, Europe accounts for 46 percent of the FRS companies' foreign refining capacity, while 36 percent of their foreign refining capacity is located in the Far East (Table 44).

\section{The Globalization of World Coal Investment}

In recent years, the structure of the U.S. coal industry has undergone considerable change. European companies-in particular, multinational conglomerates-have increased their presence in the U.S. coal industry, while other, U.S.based industry participants have reduced their role. Prominent among the latter group have been several of the smaller independent coal producers, major U.S. petroleum companies, electric utilities, and domestic steel manufacturers. These developments in the industrial organizational of U.S. coal, in part, reflect the emerging globalization of the world coal industry.

Coal accounts for 25 percent of global energy consumption, significantly less than crude oil (39 percent), but more than natural gas (22 percent). ${ }^{191}$ Ninety percent of coal production is consumed in the country of origin, primarily for the generation of electricity. ${ }^{192}$ Although only about 10 percent of world coal production makes its way into export markets, international trade in coal has grown substantially in recent years. Between 1973 and 1994, international coal trade more than doubled and is expected to increase by an additional 50 percent by 2010 . A handful of nations-and companies-account for the bulk of this trade. Australia is the largest exporter of coal, followed by the United States and South Africa. In 1994, Japan was far and away the world's largest coal importer, followed by South Korea, Taiwan, Russia, the Netherlands, Italy, Germany, and Great Britain. Although the leading world coal-producing companies include some state-owned companies, a handful of multinational conglomerates figure very prominently in worldwide coal trade and investment. These companies are primarily from the United Kingdom, Germany, the United States, and Australia. Interestingly, although Japan is the world's largest importer of coal (and also the largest importer of U.S. coal), Japanese companies have made relatively minor investments in coal assets abroad.

\section{U.S. Coal-A Growing Target of Foreign Investment}

Foreign investors have become increasingly important in the U.S. coal industry over the past decade or so. The share of foreign affiliates in U.S. coal production has grown from nearly zero in the late 1970 's to 29 percent in 1994 (Figure 26). In 1994, three of the top five U.S. coalproducing companies were foreign-affiliated, accounting for more than one-fifth of total U.S. production (Table 40). The largest foreign-affiliated producer of coal in the United States (as well as the largest producer of coal in the United States) is Peabody Holding Company. Peabody's

\footnotetext{
${ }^{190}$ Energy Information Administration, Performance Profiles of Major Energy Producers 1994, DOE/EIA-0206(94) (Washington, DC, February 1996), p. 38.

${ }^{191}$ Energy Information Administration, International Energy Annual 1993, DOE/EIA-0219(93) (Washington DC, May 1995), p. viii.

${ }^{192}$ The Mining Journal, July 1994, p. 105.
} 
Table 41. Foreign Participation in U.S. Uranium Exploration and Development, 1976-1994 (Million Dollars)

\begin{tabular}{|c|c|c|c|c|}
\hline & $\begin{array}{c}\text { Exploration and } \\
\text { Development } \\
\text { Expenditures by Foreign } \\
\text { Companies } \\
\end{array}$ & $\begin{array}{l}\text { Total U.S. } \\
\text { Exploration and } \\
\text { Development } \\
\text { Expenditures }\end{array}$ & $\begin{array}{c}\text { Foreign } \\
\text { Expenditures } \\
\text { as a Percent } \\
\text { of U.S. Total } \\
\end{array}$ & $\begin{array}{l}\text { Number of Foreign- } \\
\text { Affiliated Companies }\end{array}$ \\
\hline $1976 \ldots \ldots \ldots \ldots \ldots \ldots$ & 13.2 & 170.7 & 8 & 15 \\
\hline $1977 \ldots \ldots \ldots \ldots \ldots \ldots$ & 21.7 & 258.1 & 8 & 17 \\
\hline $1978 \ldots \ldots \ldots \ldots \ldots \ldots$ & 39.3 & 314.3 & 13 & 31 \\
\hline $1979 \ldots \ldots \ldots \ldots \ldots$ & 34.1 & 315.9 & 11 & 28 \\
\hline $1980 \ldots \ldots \ldots \ldots \ldots$ & 37.6 & 267.0 & 14 & 28 \\
\hline $1981 \ldots \ldots \ldots \ldots \ldots$ & 24.6 & 144.8 & 17 & 25 \\
\hline $1982 \ldots \ldots \ldots \ldots \ldots \ldots$ & 14.6 & 73.6 & 20 & 14 \\
\hline $1983 \ldots \ldots \ldots \ldots \ldots$ & 4.8 & 36.9 & 13 & 9 \\
\hline $1984 \ldots \ldots \ldots \ldots \ldots$ & 6.6 & 26.5 & 25 & 9 \\
\hline $1985 \ldots \ldots \ldots \ldots \ldots$ & 5.6 & 20.1 & 28 & 6 \\
\hline $1986 \ldots \ldots \ldots \ldots \ldots$ & 12.0 & 22.1 & 54 & 8 \\
\hline $1987 \ldots \ldots \ldots \ldots \ldots$ & 11.9 & 19.7 & 60 & 11 \\
\hline $1988 \ldots \ldots \ldots \ldots \ldots \ldots$ & 8.9 & 20.1 & 44 & 11 \\
\hline $1989 \ldots \ldots \ldots \ldots$ & 6.1 & 14.8 & 41 & 7 \\
\hline $1990 \ldots \ldots \ldots \ldots \ldots$ & 2.5 & 17.1 & 15 & 9 \\
\hline $1991 \ldots \ldots \ldots \ldots \ldots \ldots$ & 3.5 & 17.8 & 19 & 6 \\
\hline $1992 \ldots \ldots \ldots \ldots \ldots \ldots$ & 8.0 & 14.5 & 55 & 6 \\
\hline $1993 \ldots \ldots \ldots \ldots \ldots$ & 8.5 & 11.3 & 76 & 7 \\
\hline $1994 \ldots \ldots \ldots \ldots \ldots$ & 1.9 & 3.7 & 51 & 8 \\
\hline
\end{tabular}

Source: Energy Information Administration, Uranium Industry Annual 1994, DOE/EIA-0478(94) (Washington, DC, July 1995), pp. 7-8.

parent corporation, the British firm Hanson plc., is the world's second largest privately-owned coal producer. ${ }^{193}$ The second largest foreign-affiliated producer is Consol Coal, which is the third largest U.S. coal producer. Consol is a 50-50 joint venture between DuPont and the German company Rheinbraun AG, which is the world's largest privately held coal producer. The third largest foreignaffiliated U.S. coal producer is Kennecott Energy Company, which is owned by the British company, RTZ plc, the world's biggest mining group. Kennecott is the fourth largest producer of coal in the United States. ${ }^{194}$

A number of factors contributed to the attractiveness of the U.S. coal industry as a target of foreign investment. For one, the United States is the largest coal market open to foreign investors. In addition to being the second largest exporter of coal, the United States is the world's second largest coal consumer and producer. ${ }^{195}$

Most of the foreign investment in U.S. coal has been disproportionately European. European coal companies are motivated in part to invest in U.S. coal in order to secure sources of coal in the face of declining European production. However, this motive is apparently prospective rather than reflective of the current patterns of production and imports of coal. That is, the United Kingdom, which is the largest foreign investor in U.S. coal, ranked tenth among coal importers; Germany, the second largest investor, ranked twentieth. Japan, Canada, France, Spain, Belgium, the Netherlands, and Italy all imported more U.S. coal than the United Kingdom and Germany, but these countries had little, if any, in the way of U.S. coal investments.

Financial incentives are another possible motive for investing in U.S. coal. Were it not for the widespread exit of major petroleum companies from U.S. coal mining, this motive might appear more plausible. It was due largely to several years of under performance among their coal segments that resulted in the majors' departure from U.S. coal. Only three times in the last eighteen years did the majors' profitability in coal exceed the profitability of their consolidated operations. ${ }^{196}$

\footnotetext{
${ }^{193}$ Many of the world's largest producers of coal are not publicly traded corporations. Neither are they multinational in outlook. For instance, among the world's largest producers of coal are the national coal companies of Russia, India, and Ukraine.

194"Buy Low: Foreigners have been buyers of U.S. coal properties. What do the buyers know that the sellers don't?" Forbes, (March 15, 1994).

${ }^{195} \mathrm{China}$ is both the leading producer and consumer of world coal.

${ }^{196}$ Energy Information Administration, Form EIA-28.
} 
Table 42. Selected Financial Information for Foreign-Affiliated U.S. Energy Companies, 1993-1994 (Billion Dollars)

\begin{tabular}{|c|c|c|c|c|c|c|}
\hline \multirow[b]{2}{*}{ Category } & \multicolumn{3}{|c|}{ Foreign-Affiliated U.S. Energy ${ }^{a}$} & \multicolumn{3}{|c|}{ U.S. Energy Industry ${ }^{b}$} \\
\hline & 1993 & 1994 & $\begin{array}{l}\text { Percent } \\
\text { Change } \\
\end{array}$ & 1993 & 1994 & $\begin{array}{l}\text { Percent } \\
\text { Change }\end{array}$ \\
\hline \multicolumn{7}{|l|}{ Financial items } \\
\hline Revenues .... & 96.7 & 99.4 & 2.8 & 380.8 & 391.2 & 2.7 \\
\hline Net Income $\ldots \ldots \ldots \ldots \ldots \ldots \ldots \ldots$ & 1.9 & 4.6 & 137.2 & 14.2 & 12.6 & -10.8 \\
\hline Cash Flow ${ }^{c} \ldots$ & 12.0 & 11.4 & -4.3 & 43.5 & 41.1 & -5.5 \\
\hline Capital Expenditures.$\ldots \ldots$. & 10.8 & 10.0 & -7.7 & 42.0 & 36.5 & -13.0 \\
\hline Cash Dividends & 2.6 & 3.2 & 23.4 & 11.5 & 11.7 & 1.4 \\
\hline Total Assets . ..................... & 99.7 & 99.4 & $\begin{array}{c}-0.3 \\
\text { (percent) }\end{array}$ & 389.3 & 404.5 & 3.9 \\
\hline \multicolumn{7}{|l|}{ Financial Ratios } \\
\hline Return on Equity ${ }^{d}$ & 5.0 & 11.2 & & 9.4 & 8.1 & \\
\hline Dividends/Net Income $\ldots \ldots \ldots \ldots \ldots \ldots$ & 133.7 & 69.6 & & 181.5 & 92.7 & \\
\hline Dividends/Cash Flow $\ldots \ldots \ldots \ldots \ldots \ldots$ & 21.8 & 28.2 & & 26.6 & 28.5 & \\
\hline Debt/Equity ${ }^{e} \ldots \ldots \ldots \ldots \ldots \ldots \ldots$ & 46.1 & 41.5 & & 51.7 & 52.8 & \\
\hline
\end{tabular}

ancludes incorporated U.S. energy companies that are foreign affiliated and for which publicly reported financial information is available. Also included are foreign parent companies for which data for U.S. operations were not separately disclosed. For 1993 these companies were: Anadarko Petroleum Corp., Arabian Shield Development Co., Arakis Energy Corp., Ashland Coal Inc., Bellwether Exploration Co., Blue Dolphin Energy Co., Cairn Energy USA Inc., Canadian Occidental Petroleum Ltd., Caspen Oil Inc., Castle Energy Corp., Chieftain International Inc., Cirlce K. Corp., Citgo Petroleum, Coho Energy Inc., DI Industries, Inc., Daleco Resources Corp., E.I. du Pont de Nemours and Company, Fina Inc., Forcenergy Gas Exploration Inc., Georesources Inc., Gold King Consolidated Inc., Harcor Energy Co., Harken Energy Corp., Hondo Oil and Gas Co., Horsham Corp., Louis Dreyfus Natural Gas Corp., Lyondell Petrochemical Co., MSR Exploration, Magellan Petroleum Corp., Norcen Energy Resources Ltd., Oceanic Exploration Co., Penn Virginia Corp., Powerhouse Resources Inc., Presidio Oil Co., Ranger Oil Ltd., Reading \& Bates Corp., Rio Algom Ltd., Saba Petroleum Co., Santa Fe Energy Resources Inc., Schlumberger Ltd., Shell Oil Co., Sunlite Inc., Taurus Petroleum Inc., Tesoro Petroleum Corp., Total Petroleum (North America), Westmoreland Coal Co., XCL Ltd., Zapata Corp., and Zeigler Coal Holding Co. In 1994, the following U.S. energy companies became foreign affiliated or, if foreign based, acquired U.S. energy reserves or refining capacity: Global Marine inc., NGC Corp. The following companies were no longer foreign-affiliated in 1994: Coho Energy Inc., HarCor Energy Co., Reading and Bates Corp., Tesoro Petroleum Corp., Zapata Corp., and Zeigler Coal Holding Co.

${ }^{6}$ The comparison group is derived from aggregates available from Standard and Poor's Compustat II Industrial File for the following four digit (SIC) industries: 1220 (bituminous coal, lignite mining), 1221 (bituminous coal, lignite surface mining), 1311 (crude petroleum and natural gas production), 1381 (oil and gas well drilling), 1382 (oil and gas field exploration), 1389 (oil and gas field services not elsewhere classified), and 2911 (petroleum refining). To obtain comparison group aggregates, the Compustat aggregates were adjusted by subtracting out data for companies which have been identified as foreign affiliated, or whose operations are foreign based, or foreign-based companies whose U.S. operations are already included in U.S. companies identified as foreign affiliated.

${ }^{\mathrm{C}}$ Measured as cash flow from operations.

'Defined as net income divided by year-end stockholders' equity.

'Defined as year-end long-term debt divided by year-end stockholders' equity.

$\mathrm{NM}=$ Not meaningful.

Note: Percent changes were calculated from unrounded data.

Source: Compiled from Compustat II Industrial File and company annual reports.

Possibly the key factor motivating UK and German investors is that as inefficient European mines continue to close, multinational European coal producers have had to move abroad in order to remain in the coal business. As is evident from the discussion below, the United States and Australia, with their extensive coal reserves, established export markets, and few impediments to foreign investors, have gained prominence as targets of coal investments. 
Table 43. U.S. Direct Investment in Foreign Petroleum, 1980-1994 (Billion Dollars)

\begin{tabular}{|c|c|c|c|}
\hline & $\begin{array}{l}\text { U.S. Direct Investment } \\
\text { in Foreign Petroleum }\end{array}$ & $\begin{array}{l}\text { Total U.S. Direct } \\
\text { Investment Abroad }\end{array}$ & $\begin{array}{l}\text { Petroleum as a } \\
\text { Percent of Total }\end{array}$ \\
\hline $1980 \ldots \ldots \ldots \ldots \ldots \ldots \ldots \ldots$ & 47.6 & 215.4 & 22.1 \\
\hline $1981 \ldots \ldots \ldots \ldots \ldots \ldots \ldots \ldots$ & 53.2 & 228.3 & 23.3 \\
\hline $1982 \ldots \ldots \ldots \ldots \ldots \ldots \ldots \ldots \ldots$ & 57.8 & 207.8 & 27.8 \\
\hline $1983 \ldots$ & 57.6 & 207.2 & 27.8 \\
\hline $1984 \ldots \ldots \ldots \ldots \ldots \ldots \ldots \ldots$ & 58.1 & 211.5 & 27.5 \\
\hline $1985 \ldots \ldots \ldots \ldots \ldots \ldots \ldots \ldots \ldots$ & 57.7 & 230.2 & 25.1 \\
\hline $1986 \ldots \ldots \ldots \ldots \ldots \ldots \ldots$ & 58.5 & 259.8 & 22.5 \\
\hline $1987 \ldots \ldots \ldots \ldots \ldots \ldots \ldots \ldots$ & 59.8 & 314.3 & 19.0 \\
\hline $1988 \ldots \ldots \ldots \ldots \ldots \ldots \ldots \ldots$ & 57.8 & 335.9 & 17.2 \\
\hline $1989 \ldots \ldots \ldots \ldots \ldots \ldots \ldots \ldots$ & 48.3 & 381.8 & 12.7 \\
\hline $1990 \ldots \ldots \ldots \ldots \ldots \ldots \ldots \ldots$ & 52.8 & 430.5 & 12.3 \\
\hline $1991 \ldots \ldots \ldots \ldots \ldots \ldots \ldots \ldots$ & 57.7 & 467.8 & 12.3 \\
\hline $1992 \ldots \ldots \ldots \ldots \ldots \ldots \ldots \ldots$ & 58.5 & 502.1 & 11.7 \\
\hline $1993 \ldots \ldots \ldots \ldots \ldots \ldots \ldots \ldots$ & 63.5 & 559.7 & 11.4 \\
\hline $1994 \ldots \ldots \ldots \ldots \ldots \ldots \ldots \ldots \ldots$ & 65.7 & 612.7 & 10.7 \\
\hline
\end{tabular}

a'Direct Investment Abroad is the value of U.S. parents' net equity in, and outstanding loans to, affiliates outside the United States.

'The petroleum industry includes all phases of oil and gas exploration and production, petroleum refining, petroleum transport, and petroleum marketing.

Sources: 1989-1994 U.S. Department of Commerce, Bureau of Economic Analysis, Survey of Current Business (Washington, DC, August 1995). 1987-1988: U.S. Department of Commerce, Bureau of Economic Analysis, Survey of Current Business (Washington, DC, August 1993). 1985-1986: U.S. Department of Commerce, Bureau of Economic Analysis, Survey of Current Business (Washington, DC, August 1990). 1982-1984: U.S. Department of Commerce, Bureau of Economic Analysis, Survey of Current Business (Washington, DC, August 1987). 1980-1981: U.S. Department of Commerce, Bureau of Economic Analysis, Survey of Current Business (Washington, DC, August 1985).

\section{Changes in the European Coal Industry}

In Western Europe, coal production is concentrated, with the United Kingdom and Germany accounting for roughly four-fifths of total production and Spain and France accounting for most of the remainder. Until recently, European coal producers benefitted from protected markets and from an extraordinary array of generous subsidies, allowing European coal mines, which had become vastly inefficient by world standards, to remain in operation. In Germany, for instance, subsidies have until recently been financed by a 7.5-percent levy on electricity bills. As a consequence, domestic coal prices in Germany have been more than three times the import price. ${ }^{197}$ Electricity prices in Germany are the most expensive in Europe and 70 percent more costly than in the United States. ${ }^{198}$ However, the German coal industry has been shrinking in recent years in order to comply with European Union mandates and to remain competitive in a global market place.
The restructuring of Europe's coal industry is also due, in part, to a shift to alternative fuels. The proportion of Western Europe's energy consumption fueled by coal fell from around 80 percent in the 1950's to 25 percent in 1994. In the future, European utilities are expected to move toward greater usage of increasingly available North Sea natural gas and away from coal.

As a result of the continued elimination of coal subsidies and a shift toward natural gas, the European coal industry has been declining. In 1994, coal production in the United Kingdom declined by over 60 percent from its 1980 level, while Germany experienced a decline of almost 40 percent in hard coal production. The larger reduction in coal output in the United Kingdom was, in part, due to the more forceful elimination of subsidies undertaken by the British government. Germany has been behind schedule in doing away with coal subsidies. For Western Europe as a whole, a further 50 -percent reduction in coal production is expected over the next decade.

\footnotetext{
197"German Coal Levy is Ruled Illegal," The Financial Times (December 8, 1994), p. 2.

198"Power to the People: Cracking Europe's Electric Cartels," The Wall Street Journal (December 22, 1995).
} 
Table 44. Refinery Capacity Outside the United States for FRS Companies, 1994 (Thousand Barrels per Day)

\begin{tabular}{|c|c|c|}
\hline Region & $\begin{array}{c}\text { Crude Distillation } \\
\text { Capacity }^{\mathrm{a}}\end{array}$ & $\begin{array}{c}\text { Percent } \\
\text { Distribution }\end{array}$ \\
\hline 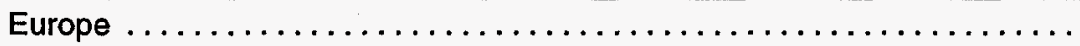 & 2,726 & 46.0 \\
\hline Latin America . . . . . . . . . . . . . . . & 416 & 6.8 \\
\hline 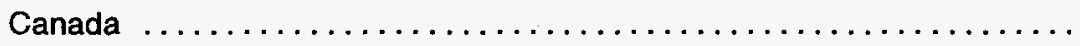 & 489 & 6.4 \\
\hline 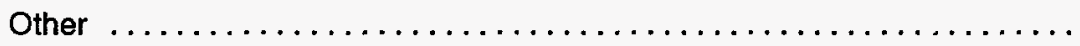 & 248 & 6.7 \\
\hline
\end{tabular}

'Includes ownership shares in investees' refineries.

Source: Company filings of Securities and Exchange Commission Form 10-K, Company annual reports, and supplements to annual reports.

\section{Figure 27. Foreign Capital and Exploratory Expenditures of the FRS Companies, 1974-1994}

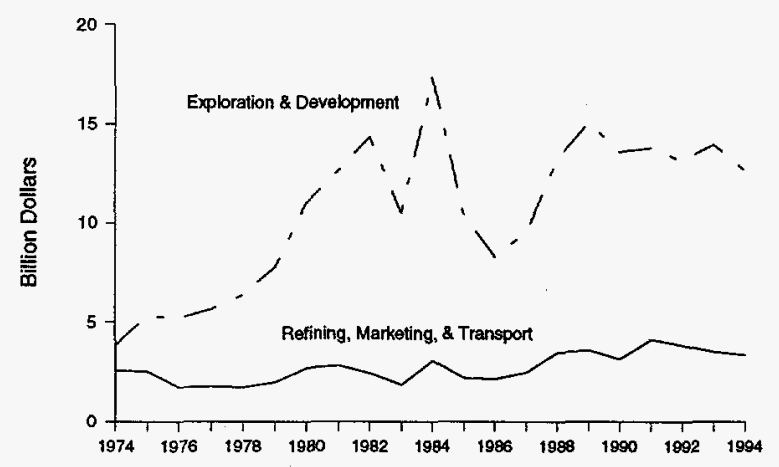

Energy Information Administration, Form E]A-28.

In contrast to European production, U.S. coal production peaked in 1994, surpassing 1 billion short tons for the second time. Further, in future years, the United States is expected to increase its coal output. Other countries expected to boost coal production and exports in future years include the largest and third largest coal exporters, Australia and South Africa. Recent entrants into the global coal trade include Colombia and Venezuela. Interestingly, with the exception of South Africa, all of the aforementioned nations' coal industries have seen increasing levels of foreign direct investment from a handful of multinational conglomerates.

\section{The Rise of Australia's Coal Industry}

Until recently, the United States was the world's primary source of coal exports. In 1970, the United States accounted for one-half of the international coal trade. ${ }^{199}$ By 1994, the U.S. share of world coal trade had declined to 15 percent of the total. In 1986, Australia supplanted the United States as the world's largest exporter of coal. As recently as 1980, U.S. coal exports were double those of Australia.

Coal is Australia's number one export. ${ }^{200}$ Some of the companies most prominent in the U.S. coal industry are also prominent in Australia's coal industry, particularly that part of the industry directed towards export markets (see the box entitled, "World Coal Producers and Australian Coal Exporters in 1994"). As in the United States, foreign investment plays a key role in Australia's coal industry, further indicating how multinational in character world coal investment has become. Australia consumes less than a third of its domestic production (versus 90 percent in the United States). Although 70 percent of Australia's coal exports goes to Japan, ${ }^{201}$ Japan's investment in Australian coal is comparatively small.

Ownership of Australian coal assets is held largely by Australian, U.S., and European companies. The largest producer of coal in Australia is the Australian multinational conglomerate Broken Hill Proprietary Company Ltd. (BHP). In addition to its Australian coal mining operations, $\mathrm{BHP}$ is the 17 th largest coal producer in the United States and also has coal mining interests in Indonesia. The second largest exporter of Australian coal

\footnotetext{
199،"Demand Strengthens with Bright Prospects Ahead," Coal (March 1995).

${ }^{200}$ Mining Magazine (September 1995), p. 146.

20l“c Coal in Europe: The Implications of Dismantled Subsidies," Coal Voice (June, 1993) p. 1.
} 
Figure 28. Exploration and Development Expenditures, by Foreign Regions, for FRS Companies, 1986, 1990, and 1994

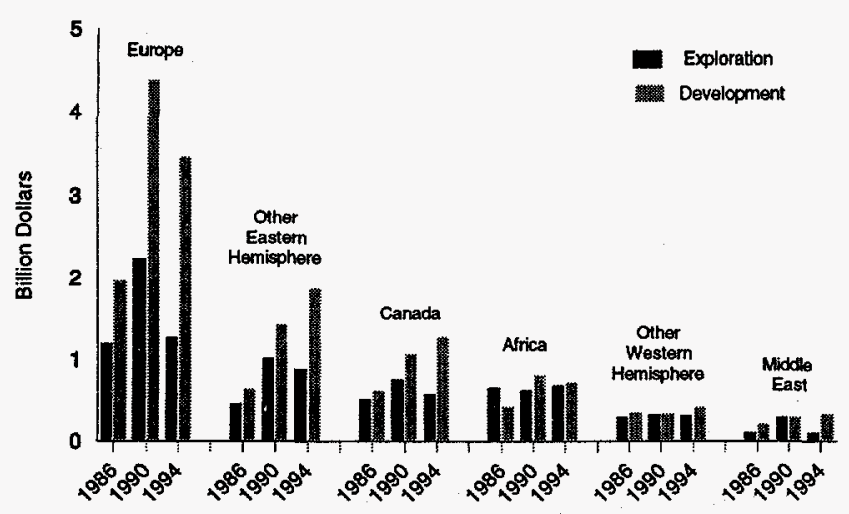

Source: Energy Information Administration, Form EIA-28.

is CRA Corp, an Australian company which has recently merged with the British company RTZ Corp. As noted earlier, RTZ Corp is the fourth largest producer of coal in the United States. Third among Australian coal producers is Cyprus Amax Minerals Company, a U.S. multinational minerals company and the second largest producer of coal in the United States. Other major exporters of Australian coal include Exxon, ARCO, and Peabody-all companies with major U.S. coal operations. The fifth largest exporter of Australian coal is Royal Dutch/Shell, which exited the U.S. coal-producing industry in 1994.

\section{South Africa's Potential}

South Africa is the third largest exporter of coal. Coal accounts for 98 percent of South African energy produc- tion and 78 percent of energy consumption. ${ }^{202}$ South Africa ranks seventh in coal reserves. ${ }^{203}$ For most of the last decade or so, United Nations' sanctions have restricted the flow of foreign direct investment to South African industries. Even in 1994, the year in which sanctions were lifted, foreign direct investment in South Africa was less than in $1980 .^{204}$ Although they are primarily domestically-held corporations, South African coal mining companies are among the largest in the world. With the lifting of the U.N. sanctions, South Africa coal mining could become a target of foreign direct investment and a growing source of coal exports.

\section{Colombia and Venezuela}

Another important area of recent international investment in coal lies in Latin America, primarily Colombia and Venezuela. Colombia is far and away the largest producer of coal in Latin America, followed by Brazil and Venezuela. ${ }^{205}$ Colombia also has Latin America's largest coal reserves. Currently ranked ninth in the world in terms of exports, Colombia is expected to play an increasingly important role in world coal trade in the future.

Again, several of the companies investing in Latin American coal mining are those with coal investments in the United States and Australia. The Italian energy company, AGIP, mines coal in Venezuela, as does Royal Dutch/Shell and the German energy conglomerate Ruhrkohl. Veba also has coal mining operations in the United States. ${ }^{206}$ Both Exxon and Drummond have coal investments in Colombia. Although Brazil is the second largest producer of coal, it is a net importer, while almost all of Venezuela's state-controlled coal production is directed towards export markets.

\footnotetext{
${ }^{202}$ Energy Information Administration, Country Energy Profiles, South Africa (Washington DC, August 1995), p. ii.

${ }^{203}$ Energy Information Administration, Country Energy Profiles, South Africa (Washington DC, August 1995), p. ii.

204،"Emerging Market Indicators," The Economist (December 23, 1995 - January 5, 1996), p. 126.

${ }^{205}$ Although Brazil is the second largest producer of coal it is a net importer, while almost all of Venezuela's coal production is directed towards export markets.

${ }^{206}$ European Energy Report (April 26, 1996).
} 


\section{World Coal Producers and Australian Coal Exporters in 1994}

\section{World's 15 Largest Privately \\ Held Coal Companies ${ }^{a}$ in 1994}

Rheinbraun (Germany)

Hanson plc (Peabody Holding

Company(UK))

Cyprus Amax Corp (U.S.)

Ingwe (South Africa)

Laubag (Germany)

Consol Coal Group (United States and Germany)

RTZ (UK) ${ }^{c}$

Ruhrkohle (Germany)

Zeigler (U.S.)

ARCO Coal (U.S.)

Exxon Coal and Minerals (U.S.)

CRA (Australia)

North American Coal Corp (U.S.)

Texas Utilities Mining (U.S.)

Kerr McGee Coal (U.S.)
Top 10 Coal Producers in the
United States in $1994^{\mathrm{b}}$

United States in 1994

Peabody Holding Company

(Hanson plc., UK)

Cyprus AMAX Minerals (U.S.)

Consol Energy Inc.

(50-percent U.S.)

(50-percent Germany)

Kennecott (RTZ Corp. plc, (UK))

Zeigler Coal Holding Co. (U.S.)

ARCO Coal Co. (U.S.)

Montana Power Co. (U.S.)

North American Coal Corp (U.S.)

Texas Utilities Co. (U.S.)

Kerr-McGee Coal Corp (U.S.)
Top 10 Coal Exporters in Australia in $1994^{\mathrm{a}}$

BHP (Australia)

CRA (Australia)

Cyprus AMAX Coal (U.S.)

MIM Holdings (Australia)

Shell Coal Australia (UK)

Exxon Coal and Minerals (U.S.)

ARCO Coal (U.S.)

Peabody Holding Company (U.K.)

Oceanic Coal (Australia)

Idemitsu South QId Coal (Japan)

anWorld Coal,"Mining Magazine (September 1995), Table 5.

${ }^{b}$ Energy Information Administration, Coal Industry Annual 1994, DOE/EIA-0584(94) (Washington D.C. October 1995), Table 14. For foreign affiliates, parent company is in parentheses.

${ }^{\circ}$ RTZ and CRA Ltd. announced that the companies would merge: Coal Outlook (October 16, 1995), p. 3. This would make the combined company the world's second largest privately held coal-producing company. 
Appendix A

Structure of the Financial Reporting System-Form EIA-28 



\section{Appendix A}

\section{Structure of the Financial Reporting System - Form EIA-28}

\section{Reporting Format}

The FRS data system is designed to permit review of the functional performance of major energy-producing companies in total, as well as by specific functions and geographic areas of operation. The financial reporting schedules obtain data on revenues, costs, and profits, thereby indicating financial flows and performance characteristics. In addition, Form EIA-28 is used to collect balance sheet data (e.g., accumulated property, plant, and equipment), along with data on new investment in these accounts. To complement the financial data, statistical schedules are included to trace physical activity patterns and to evaluate several physical and financial relationships.

In greater detail, the structure of the reporting package is as follows:

\section{Financial Reporting}

a. The starting point is the three basic financial statements required by the Securities and Exchange Commission (SEC) Form 10-K:

i. Consolidating Statement of Income (Schedule 5110)

ii. Selected Consolidating Financial Data (Balance Sheets) (Schedule 5120)

iii. Consolidated Statement of Cash Flows (Schedule 5131)

b. Company-wide financial information is first disaggregated by functional lines (segments) on Schedules 5110 and 5120 as follows:
i. Petroleum
ii. Coal
iii. Other Energy (includes Nuclear)
iv. Nonenergy (includes Chemicals)

c. Nonenergy data are collected to characterize corporate resource investment strategies and to allow aggregation of the FRS detailed schedules into the consolidated company amounts.

2. Operating and Statistical Information

a. For each type of energy activity, complementary operating information is obtained through the following schedules:

i. Petroleum (Schedule 5211-Schedule 5246)

ii. Coal (Schedule 5341)

b. The schedules are designed to correspond to the financial information so that level of effort in the financial sense can be compared to physical results.

\section{Complementary Schedules}

a. Examine corporate research and development funding priorities (Schedule 5111)

b. Reveal impact of tax policy on financial results of reporting companies (Schedule 5112)

c. Monitor raw materials acquisition and refined product disposition strategies of FRS companies (Schedule 5211 and Schedule 5212)

d. Trace changes in reserves for petroleum (including natural gas) (Schedule 5246) and coal (Schedule 5341).

\section{Petroleum Segment Overview}

The petroleum line of business is further disaggregated into segments. ${ }^{207}$ These segments are presented as though each were a separate entity, with certain limitations,

\footnotetext{
${ }^{207}$ The other lines of business (Coal, Other Energy, and Nonenergy) were also disaggregated into segments, but only through 1986.
} 
The following lists each segment within the petroleum line of business, along with a brief description of that segment's principal revenue-generating product or service. (Further detail on the FRS petroleum segments can be found in the section on FRS Petroleum Supply and Trading Function and FRS Income Taxes.)

1. U.S. Production - produces and sells U.S. crude oil, natural gas, and natural gas liquids. For FRS purposes, sales of U.S. crude oil must be made to the U.S. refining/marketing segment. Natural gas and natural gas liquids can be purchased from or sold directly to U.S. or foreign third parties, unconsolidated affiliates, and other U.S. or foreign segments.

2. U.S. Refining/Marketing - purchases raw materials from the U.S. production segment, the foreign refining/marketing segment, and third parties for refining or sale to third parties. The segment also purchases directly from the foreign production segment for those companies that do not have foreign refining/marketing and import all foreign production and purchases.

3. U.S. Pipelines - transports crude oil, natural gas, and natural gas liquids through Federal-or State-regulated pipeline operations.

4. Foreign Production - produces and sells foreign crude oil, natural gas, and natural gas liquids. Crude oil sales are made to the foreign refining/marketing segment unless the company does not have foreign refinery operations and imports all foreign crude oil gained through production or purchases. Companies that meet these criteria may sell directly to the U.S. refining/marketing segment.

5. Foreign Refining/Marketing - purchases raw materials from foreign production segments and U.S. refining/marketing segments, refines, and sells to third parties and refining/marketing segments.

6. International Marine - provides marine transportation of foreign and U.S. source crude oil.

\section{Selection of FRS Reporting Companies}

Twenty-seven companies were initially notified of a requirement to file Form EIA-28. This group was chosen initially from the top 50 publicly-owned U.S. crude oil producers, who, in 1976, had at least 1 percent of either production or reserves of oil, gas, coal, or uranium in the
United States or 1 percent of refining capacity or petroleum product sales in the United States.

Mergers, acquisitions, and spinoffs, together with the selection criteria applied to 1991 data, resulted in the list of companies shown in Table A1 on the following page.

\section{Data Quality Assurance Program}

The data quality assurance program encompasses EIA's efforts to ensure the quality and integrity of FRS data. These efforts are evidenced by the design of the form and by the procedures applied to verify the data, including computer programmed checks and desk review procedures.

\section{Forms Design}

The Securities and Exchange Commission (SEC) Form 10$\mathrm{K}$ contains financial statements audited by independent certified public accountants. These financial statements and the entire text of the annual report and Form $10-\mathrm{K}$ are reviewed by the SEC staff to provide the investing public with assurances that data filed on Form 10-K are accurate and are in accordance with generally accepted accounting principles and SEC Regulations.

The FRS Form EIA-28 is designed in a multi-tier structure to take advantage of the SEC review and audit by independent certified public accountants. This structure presents both the Form 10-K figures and statistics and the more detailed data required by the FRS system. The top FRS tier corresponds to Form 10-K; the second tier is the first tier disaggregated into the different sources of energy (e.g., petroleum, coal); and the third tier is the second tier disaggregated into the specific functional line-of-business segments within petroleum. (See the Petroleum Segment Overview section at the beginning of this appendix, which describes the FRS segments in detail.) The fourth tier provides further detail within the individual segmentsfor example, the details of petroleum raw materials purchased and sold. Therefore, the lower tiers can be aggregated to each successively higher tier until the consolidated Form $10-\mathrm{K}$ figures are reached. In this way, the more detailed FRS data is tied to the aggregated figures already reported publicly to the SEC and to company shareholders.

\section{Review Procedures}

Detailed computer editing and desk review procedures have been established for the incoming FRS data. The result of each review is the issuance of a letter to the reporting company containing questions regarding data 
Table A1. Companies Reporting to the Financial Reporting System, 1974-1995

\begin{tabular}{|c|c|c|c|c|c|c|c|c|c|c|}
\hline Company & 1974-81 & 1982 & 1983-84 & $1985-86$ & 1987 & 1988 & 1989-90 & 1991 & $1992-93$ & $1994-95$ \\
\hline American Petrofina, Inc. ${ }^{\text {a }}$ & $\mathrm{x}$ & $x$ & $x$ & $x$ & $\mathrm{x}$ & $\mathrm{x}$ & $x$ & & & $\therefore$ \\
\hline Amoco Corporation ${ }^{6}$ & $x$ & $x$ & $x$ & $x$ & $x$ & $x$ & $\mathrm{x}$ & $\mathrm{x}$ & $x$ & $x$ \\
\hline Ashland Inc. & $x$ & $x$ & $x$ & $x$ & $\mathrm{x}$ & $x$ & $\mathrm{x}$ & $x$ & $x$ & $x$ \\
\hline Atlantic Richfield Co. (ARCO) & $x$ & $x$ & $x$ & $x$ & $x$ & $x$ & $x$ & $x$ & $x$ & $x$ \\
\hline BP America, Inc. ${ }^{c}$ & & & & & $x$ & $x$ & $x$ & $x$ & $x$ & $x$ \\
\hline Chevron Corporation ${ }^{\text {f }}$ & $x$ & $x$ & $x$ & $x$ & $x$ & $x$ & $x$ & $x$ & $x$ & $x$ \\
\hline Citles Service $^{g}$ & $\mathrm{x}$ & $\mathrm{x}$ & & & & & & & & \\
\hline Coastal Corporation & $x$ & $\mathrm{x}$ & $x$ & $x$ & $\mathrm{x}$ & $x$ & $x$ & $x$ & $x$ & $x$ \\
\hline Conoco ${ }^{\mathrm{h}}$ & $x$ & & & & & & & & & \\
\hline E.I. du Pont de Nemours and Co. ${ }^{h}$ & & $x$ & $x$ & $x$ & $x$ & $x$ & $x$ & $x$ & $x$ & $x$ \\
\hline Enron Corporation & & & & & & & & & $x$ & $x$ \\
\hline Kerr-McGee Corporation & $x$ & $\mathrm{x}$ & $\hat{x}$ & $x$ & $\mathrm{x}$ & $x$ & $x$ & $x$ & $x$ & $x$ \\
\hline Marathon & $x$ & & & & & & & & & \\
\hline Mobil Corporation ${ }^{k}$ & $x$ & $x$ & $x$ & $x$ & $x$ & $x$ & $x$ & $x$ & $x$ & $x$ \\
\hline Nerco, Inc. & & & & & & & & & $x$ & \\
\hline Occidental Petroleum Corporation ${ }^{9}$ & $x$ & $x$ & $x$ & $x$ & $x$ & $x$ & $x$ & $x$ & $x$ & $x$ \\
\hline Oryx Energy Company ${ }^{\mathrm{m}}$ & & & & & & $\hat{x}$ & $\hat{x}$ & $x$ & $\mathrm{x}$ & $x$ \\
\hline Phillips Petroleum Company & $x$ & $x$ & $x$ & $x$ & $x$ & $x$ & $x$ & $x$ & $x$ & $x$ \\
\hline Shell Oll Company & $x$ & $\mathrm{x}$ & $x$ & $\mathrm{x}$ & $\mathrm{x}$ & $\hat{x}$ & $x$ & $\ddot{x}$ & $x$ & $x$ \\
\hline Standard Oil Co. (Ohio) $(\mathrm{SOHIO})^{c}$ & $x$ & $\mathrm{x}$ & $x$ & $x$ & & & & & & \\
\hline Sun Company, inc. ${ }^{m}$ & $x$ & $\mathrm{x}$ & $x$ & $x$ & $x$ & $x$ & $x$ & $x$ & $x$ & $x$ \\
\hline Superior Oil ${ }^{k}$ & $x$ & $\mathrm{x}$ & $\hat{x}$ & & & & & & & \\
\hline Tenneco Inc. $^{n}$ & $x$ & $x$ & $x$ & $x$ & $x$ & $x$ & & & & \\
\hline Texaco Inc. & $x$ & $x$ & $x$ & $x$ & $\mathrm{x}$ & $x$ & $x$ & $x$ & $x$ & $x$ \\
\hline
\end{tabular}

${ }^{a}$ American Petrofina, Inc. changed its name to Fina, Inc., effective April 17, 1991.

${ }^{\mathrm{b}}$ Formerly Standard Oil Company (Indiana).

In 1987, British Petroleum acquired all shares in Standard Oil Company (Ohio) that it did not already control and renamed its U.S. affiliate, BP America.

'Burlington Resources was added to the FRS system and Burlington Northem was dropped for 1988. Data for Burlington Resources covers the full year 1988 even though that company was not created until May of that year.

${ }^{\text {E }}$ Formerly Standard Oil Company of California.

${ }^{f}$ Chevron acquired Gulf Oil in 1984, but separate data for Gulf continued to be available for the full 1984 year.

OOccidental acquired Cities Service in 1982. Separate financial reports were available for 1982, so each company continued to be treated separately until 1983.

"DuPont acquired Conoco in 1981. Separate data for Conoco were available for 1981; DuPont was included in the FRS system in 1982.

Texaco acquired Getty in 1984; however, Getty was treated as a separate FRS company for that year.

JU.S. Steel (now USX) acquired Marathon in 1982.

${ }^{k}$ Mobil acquired Superior in 1984 , but both companies were treated separately for that year.

'RTZ America acquired the common stock of Nerco, Inc., on Feb. 17, 1994. In Sept. 1993, Nerco, Inc. sold Nerco Oil \& Gas, Inc., its subsidiary. Nerco's 1993 submission includes operations of Nerco Oil \& Gas, Inc., through Sept. 28, 1993.

${ }^{m}$ Sun Company spun off Sun Exploration and Development Company (later renamed Oryx Energy Company) during 1988. Both companies were included in the FRS system for 1988; therefore, some degree of duplication exists for that year.

"Tenneco sold its worldwide oil and gas assets and its refining and marketing assets in 1988. Other FRS companies purchased approximately 70 percent of Tenneco's assets.

${ }^{\circ}$ Effective June 1, 1991, Total's exploration, production, and marketing operations in Canada were spun off to Total Oil \& Gas, a new public entity.

" $X$ " indicates that the company was included in the FRS system for the year indicated.

Source: Energy Information Administration, Form EIA-28. 
elements. The reporting companies respond to each question, either by explaining the item or by amending any incorrect schedule. Amended schedules are reprocessed like the original with the full range of desk and computer checks. The result of this process is an internally consistent database that has been reconciled to the Form $10-\mathrm{K}$ and from which the output reports can be compiled.

The FRS review procedures include:

- Computer programmed checks for mathematical accuracy (e.g., addition and subtraction)

- Computer programmed checks to insure that corresponding schedules are correctly crossreferenced

- Desk reviews comparing reported FRS data to information from each company's Form 10-K and annual report

- Desk reviews comparing reported data (e.g., average cost per foot drilled) for an individual FRS company to the average for all FRS reporting companies and to prior year information of the individual company

- Desk reviews comparing reported data to other related data series to ascertain any unusual variance

- Statistical disclosure avoidance procedures.

\section{Computer Programmed Checks}

There are 803 computer programmed checks for mathematical accuracy which ensure that each horizontal and vertical total equals the sum of the amounts within each line or column. There are also 50 computer programmed cross-reference checks which ascertain that the amounts within a certain section of a schedule equal the amounts of the same description within a different schedule. The cross-reference checks are performed to ensure accuracy and consistency between different schedules. For example, the amount reported on Schedule 5210 for the U.S. production segment charges for depreciation, depletion, and amortization is cross-referenced to ensure the same amount is reported on Schedule 5120. Since the number and type of errors noted during these checks is an indicator of respondent understanding of the form, existing and potential problems are identified. The FRS review staff can then focus most of their attention on specific companies and areas where data accuracy may be of a greater concern.

\section{Desk Review Procedures}

Desk review procedures encompass a detailed comparison of the data submitted to information contained in the Form 10-K and the annual report to company shareholders as well as other publicly available information.

As stated previously, the Form $10-\mathrm{K}$ and the annual report contain financial information audited by independent certified public accountants. This financial information, along with textual and statistical information, has also been reviewed by the SEC staff, which includes not only accountants, lawyers, and financial analysts, but also petroleum and mineral resource engineers. Hence, the data contained in these documents is considered a valuable reference in connection with the quality of FRS data.

The data contained in each respondent's submission is compared to the data on Form 10-K and the annual report material using a detailed review program. Each review program step is performed by trained auditors supervised by CPA's with experience in auditing medium-to-large public companies.

These comparisons involve checking elements in both the financial and physical information areas (e.g., production, reserves, refinery statistics, etc.). Direct comparisons are made of specific data elements from the FRS form with corresponding items on Form 10-K or in the annual report. Indirect comparisons deal with information that is mentioned in Form 10-K and the annual report, but which is not quantified sufficiently for direct matching with FRS data. For example, if a respondent's annual report discussed an investment in coal, appropriate entries would be expected on the FRS schedule for coal.

The FRS desk review procedures also include two other types of comparisons. The first type of comparison is made against prior year FRS data of the reporting company as well as the average data for all FRS reporting companies. These procedures ensure consistency and reasonableness across reporting years.

The second procedure involves comparison to other related data series. Information contained in the FRS system is compared to data available from other DOE systems and published data, such as State mining surveys.

The FRS desk review procedures described above often lead to the formulation of a set of questions that are issued to the reporting companies each year. Response to these 
questions generates substantial interchange between the energy company staffs and the FRS staff. From this interchange the company personnel acquire a better understanding of the unique aspects of the FRS system. The FRS staff learns more about each reporting company, the industry, and how each company's accounting and reporting practices might affect the published FRS aggregate data.

\section{Statistical Disclosure Avoidance Procedures}

Procedures to prevent the disclosure of "individually identifiable energy information" have been applied to each table in this report. These tables provide summary rather than company-specific information. In most cases, the level of summarization applies to all FRS companies. In certain cases, subcategories have been established that break the reports into size or other descriptive classes. Each table has been screened to ensure that no statistical disclosure will occur.

A large number of summary computer reports, generated from a single selected database, provide the basis for these tables. In conjunction with the summary reports, a parallel set of cell count reports were produced that tabulate for each report cell the number of nonzero values that were aggregated to produce the summary value. The cell count reports were then reviewed to identify whether potential disclosure problems would result from having an insufficient number of reporters or from having values that represent primarily dominant companies in a particular energy sector or activity.

If potential disclosure problems are identified, the tables are restructured to combine values or groups of individual cells in the tables so that the resulting tables are essentially disclosure free.

\section{Financial Analysis Guide}

\section{Indicators of Financial Performance}

To depict the activities of the FRS companies classified by the various energy industries, several indicators have been selected to show the amounts and geographic distribution of production, profits, cash generated, accumulated investment, and annual new investment. These indicators are compared across segments, across functions within segments, and geographically. They are the same, or similar, to indicators that have been in regular use by financial analysts and economists for many years.
However, to avoid potential misunderstandings, the measures used, their significance, and their limitations are described below.

All of these measures are based upon the existing framework of financial reporting now used by industry, which relies on Generally Accepted Accounting Principles (GAAP). GAAP is the set of accounting principles by which industry reflects the financial results of operations, cash flows, and financial position of individual business enterprises. The two primary issues one must contend with in using present GAAP-based data is that not all companies use the same GAAP accounting methods (e.g., full cost versus successful efforts in petroleum) and GAAP is based upon historical cost accounting principles (inflationary distortions and market values are not reflected). Both of these can cause a degree of noncomparability of reported data across companies in the case of accounting methods and through time in the case of historical cost accounting. In spite of these problems, the data are regarded as meaningful, especially for trend analysis. (For a further discussion of these two problems, see the Accounting Practices section of this appendix.)

The financial measure of the production and distribution of raw materials and refined products is operating revenues, or sales. Under GAAP, this measure is based on arms-length transactions with third parties. However, in the FRS system the concept of sales has been extended to include sales from one segment to another. In such an approach, one segment's sales become another segment's costs, which must be eliminated in consolidation. The establishment of the FRS segments, the definition of sales (trading function), and the nontraceable and eliminations categories are discussed more fully in the Accounting Practices section of this appendix.

Profits are the measure of financial return for company activities. In the FRS system, profits are expressed in terms of net income, operating income, and contribution to net income. The first term applies only to the consolidated company profits, and represents income after the provision for income tax expense. Operating income applies both to the segments and to the consolidated company and is the net of operating revenues and operating expenses. Excluded from this figure are such items as income taxes, interest income, and interest expense, which are not allocated to the segments because they are "corporate-level" items for FRS system purposes. (This is explained more fully in the Accounting Practices section of this appendix.) Contribution to net income is meant to be the equivalent of net income for individual segments and excludes several corporate-level items which are not allocated to the segment level. 
"Cash flow from operations" is presented for the consolidated company. It generally follows the indirect or reconciliation method of reporting cash flow from operations allowed by Statement of Financial Accounting Standards No. 95. The indirect method adjusts net income to remove the effects of changes in receivables, payables, and inventory during the year. The indirect method also adjusts for the effects of depreciation, depletion, and amortization, gains or losses on disposition of property, plant, and equipment, and other items. "Cash flow from operations" represents the cash effects of producing and delivering the company's products and services. This presentation is useful in analyzing the ability to generate future positive cash flow, adequacy of cash flow in relation to current obligations, and the relationship of net income to cash flow.

Accumulated investment is expressed by: (1) total assets; (2) net property, plant, and equipment (PP\&E); (3) investments and advances to unconsolidated affiliates; and (4) net investment in place.

Total assets are used in the context of the consolidated company figures and are the total of the left-hand, or asset side, of the balance sheet.

Net PP\&E is frequently used as a measure of resources committed by an enterprise to an industry or segment. In the energy industry, net PP\&E accounts for the bulk of the consolidated assets.

Investments and advances to unconsolidated affiliates are of interest because many energy companies extend the range of their activities through subsidiaries of which they own less than 50 percent.

Finally, net investment in place is the total of: (1) net PP\&E and (2) investments and advances to unconsolidated affiliates.

Annual new investment is the measure of newly committed resources during any given year. In the FRS system, this is expressed in terms of: (1) additions to PP\&E; (2) current capitalized exploration and development (E\&D) expenditures; (3) current expenditures on E\&D; (4) additions to investment in unconsolidated affiliates; and (5) additions to net investment in place. The key words are: current, which means simply a current commitment of resources; and capitalized, which refers to expenditures that are classified as an addition to the PP\&E account in the balance sheet rather than as an expense of the current year in the income statement. Being capitalized indicates that the expenditure benefits future years and will be amortized to expense in the years benefitted. Being expensed means the cost does not directly benefit a future period; therefore, the cost should be shown as an expense of the current year. The capitalization concept is at the heart of the difference between the successful efforts versus full cost accounting methods (discussed in the Accounting Practices section of this appendix). Therefore, in the FRS system, total expenditures that are both expensed and capitalized are used as a measure of activity to standardize the measurement of resources invested.

\section{Foreign Reserve Interests}

This category includes all three types of foreign reserves collected on Form EIA-28: (1) net ownership interest reserves; (2) proportionate interest in investee reserves; and (3) foreign access reserves. These three foreign categories are added together for purposes of comparison with U.S. net working interest reserves because of the different nature of company interests in foreign production as compared to U.S. production.

Foreign petroleum reserve statistics are not strictly comparable to those of U.S. petroleum reserves because of the more complex and varying arrangements whereby U.S. companies obtain foreign crude oil. In addition, such arrangements have been known to be changed suddenly by those governments, thereby imposing a degree of uncertainty about what a reporting company can describe as their equity reserves. Foreign reserve statistics may be used as an indicator of the rate and magnitude of industry activity, but the fact that their character is distinct from those of U.S. reserves must be recognized.

\section{Accounting Practices}

\section{Relation of FRS to Generally Accepted Accounting Principles}

In completing Form EIA-28, with one exception noted below, companies use the same generally accepted accounting principles that they use in their financial statements filed with the SEC and in their annual reports to shareholders. Therefore, the amount and timing of income recognized and the capitalization policies will be the same. Net income in the FRS system will agree in total with that reported in each company's financial statements.

However, in the FRS system the presentation of the details of financial and statistical data will usually differ somewhat from that presented by most individual companies because current reporting standards do not require standardized business segments with standardized financial statement line items. In the FRS system, such standardization is necessary because of the need to aggregate a large number of companies (see Sec. 205(h), P.L. 95-91). 


\section{FRS Petroleum Supply and Trading} Function

In establishing the FRS functional lines of business for reporting the activities of vertically integrated enterprises, it was necessary to define a set of trading rules. Each segment can engage in activities as defined by the rules. Otherwise, the segment data would be inconsistent between companies.

FRS defines the following segments within petroleum; they are the main components of the 5200 series schedules:

- U.S. Production

- U.S. Refining/Marketing

- U.S. Pipelines

- Foreign Production

- Foreign Refining/Marketing

- International Marine (Transportation).

A few of the more noteworthy rules, intended to make the trading activities of each FRS reporting company comparable to those of the other companies, are as follows:

1. Transfers (sales) between segments of the same company are recorded at arm's-length market prices. Where there are no comparable arm's-length transactions, field posted prices may be used. If third party realizations for specific raw material streams are below posted prices, the same lower prices should be used to value internal transfers of those raw materials.

2. All crude oil produced is recorded as a sale by the respective foreign or U.S. production segments to the corresponding foreign or U.S. refining/marketing segments. The production segments are not permitted to sell crude oil directly to third parties, but instead must transfer it to the company's refining/marketing segments which sell, in turn, to the third parties. Companies that do not have foreign refining and import all foreign purchases may deviate from this practice and sell directly to U.S. refining/marketing.

3. Crude oil purchased from third parties is reflected as a purchase by the appropriate refining/marketing segment: foreign refining/marketing for foreign source crude oil and U.S. refining/ marketing for U.S. source crude oil. Foreign source crude oil destined for a U.S. refining segment is then recorded as a sale by the foreign refining/ marketing segment to the U.S. refining/marketing segment.
4. Although production segments are neither sellers nor purchasers of crude oil from third parties, by FRS system convention, natural gas may be both purchased and sold by production segments.

5. All transportation costs are incurred by the purchasing segment. Therefore, when U.S. refining/marketing segments purchase crude oil from foreign refining/marketing segments, the U.S. refining/marketing segment incurs the transportation cost.

6. With regard to sales to third parties, an export sale is a sale shipped free on board (f.o.b.) destination to a foreign location. In contrast, if a sale is made f.o.b. to a U.S. location, it is considered a U.S. sale even though the goods may ultimately be shipped overseas by a third party who purchased the goods.

7. A U.S. purchase is a purchase made from U.S. sources, even though, in the case of goods purchased from third parties, the materials purchased may be of foreign origin. In the FRS system, the point of purchase and not the country of production is the determining factor.

\section{Nontraceables and Eliminations}

One of the objectives of the FRS system is to allow economic and financial analysis of the energy industry to be performed by individual functions. These functions, referred to in the FRS system as segments, are presented as separate entities with their own income statements. They reflect sales and purchases not only to and from unaffiliated parties, but also to and from other segments. Because the segments are not separate entities, but are part of an integrated firm, two special classifications are defined which allow reconciliation of consolidated company figures with those of the segments.

The first is the nontraceable classification, which covers those items included in the consolidated financial statements but not allocated to the segments. The second is the eliminations classification, which prevents double counting of intersegment transactions when the segments are consolidated into total company figures.

The nontraceable classification captures assets, liabilities, revenues, and expense items that cannot be attributed to the activities of a segment. In the FRS data, this classification reflects general overhead for the consolidated firm as well as financial activities which represent corporatelevel activities. 
While the financial transactions may play a key role in the firm's ability to do business, such transactions are not allocated to activities in an individual segment. Cash, corporate investments, interest income, and interest expense are examples of nontraceable items. The accompanying example illustrates a nontraceable item, interest expense of $\$ 20$, and the $\$ 10$ corresponding tax effect. (See "FRS Segment Tax Allocation Rules" in this appendix for further explanation).

The need for the eliminations classification arises when the product of one segment is sold to a second segment, which, in turn, sells the product again. In the example illustrated in Table A2, $\$ 80$ of crude oil is sold by the U.S. production segment to the refining/marketing segment. The refining/marketing segment records $\$ 80$ of purchases of crude oil and, after processing, reflects sales of $\$ 160$ of refined product. If the segment figures were simply added to arrive at the consolidated total, the consolidated sales figure of $\$ 240(\$ 80+\$ 160$ ) would be too high because of double counting. Thus, the eliminations classification subtracts $\$ 80$ of sales and $\$ 80$ of costs, leaving consolidated sales of $\$ 160$, the appropriate measure of the firm's consolidated transactions.

The nontraceables and eliminations classifications are treated as if they are segments for purposes of aggregating segment data to the consolidated level.

\section{FRS Income Taxes}

FRS Segment Tax Allocation Rules. In the FRS system, the tax allocated to each segment reflects a pro-rata share of consolidated income taxes. Where the consolidated company reports income and pays a tax, but an individual segment incurs a loss, the segment with a loss reflects a tax benefit. This treatment is an FRS rule whose purpose is to reflect, at the segment level, the effect of the segment's operations on the consolidated income taxes. The tax benefit reflected at the segment level is limited to the extent it offsets taxes in other segments on a consolidated basis.

In comparing an FRS company's segment to a specialized (nonintegrated) company in the same line of business, one must consider the effect of the above described rule. The current tax effect may be different, since a specialized company cannot report tax benefits for operating losses incurred in that year. It must carry the loss forward, or backward, against profits of other years, while a segment of an otherwise profitable consolidated firm can show a tax benefit by FRS conventions because a segment's loss can offset profits in other segments on a consolidated basis.

FRS Reporting Companies, Segments, and Tax-Paying Entities. FRS reporting companies and their segments differ from the entities which actually pay income taxes. The FRS system reports energy activities on a consolidated company basis, disaggregated into various energy lines of business. Accordingly, income tax expense, current and deferred, is reflected on a line-of-business basis. However, under the tax laws, taxes are not necessarily based upon FRS reporting company consolidated earnings of the FRS line-of-business segments.

The tax-paying entities of an FRS reporting company are its subsidiaries. Some are incorporated in the United States and some in foreign countries, and each may operate

Table A2. Example of Nontraceables and Eliminations

\begin{tabular}{|c|c|c|c|c|c|}
\hline Revenues . . . . . . . . . . . & 160 & $(80)$ & - & 160 & 80 \\
\hline General and Administrative . & 10 & - & 2 & 5 & 3 \\
\hline Other Operations & 10 & $\cdot$ & - & 5 & 5 \\
\hline Operating Income $\ldots . . \ldots$ & 140 & - & (2) & 70 & 72 \\
\hline Less Interest Expense ... & 20 & - & 20 & - & - \\
\hline Less Income Taxes ....... & 60 & - & (11) & 35 & 36 \\
\hline Net Income & 60 & - & $(11)$ & 35 & 36 \\
\hline
\end{tabular}

Note: Numbers in parentheses are negative. 
in the United States, foreign countries, or both. Income tax expense in the FRS system consists of both U.S. and foreign income taxes incurred by these subsidiaries. Taxes reflected by the consolidated company and each individual segment are allocated from taxes paid and deferred by the actual tax-paying entities.

The United States taxes only income of foreign corporations earned in the United States or paid into the United States as dividends to a U.S. parent corporation (owner). All income subject to U.S. tax, whether the entity is a foreign or U.S. corporation, is given the benefit of the foreign income tax credit (up to the statutory rate) to avoid double taxation. Each U.S. incorporated subsidiary of a U.S. corporation elects either to be included in a consolidated U.S. tax return or to file a separate return, depending on which election is most likely to minimize the aggregate U.S. and foreign taxes. In the FRS system, corporate organization and relationships are not purely a function of line-of-business financial reporting. This fact requires that allocations be made of taxes incurred so that they can be classified according to the FRS segment format. These allocations are required when a subsidiary is involved in both U.S. and foreign operations and/or in more than one line of energy business. For example, the FRS system has separate segments for the foreign and U.S. petroleum production business, and for the foreign and U.S. refining/marketing business. Therefore, if an FRS reporting company has a foreign subsidiary involved in both petroleum production and refining/marketing of petroleum, a disaggregation of that subsidiary's activities, including income taxes, must be performed.

The disaggregation is further complicated by the existence of nontraceable items, such as interest expense, interest income, minority interest and foreign currency gains and losses. The nontraceable column must be treated as a separate segment when the tax allocation is made.

\section{Deferred Taxes}

The Financial Accounting Standards Board (FASB) began working on a project to reexamine the generally accepted accounting procedure for income taxes in September 1982. Accounting Principles Board Opinion 11 ("APB 11"), issued in 1967, faced criticism and concerns about the inconsistencies in its amendments and interpretations. In addition, problems created by new tax depreciation methods and changes in accounting for income taxes in other countries were making APB 11 outdated. In 1988, the FASB issued Statement of Financial Accounting Standards.No. 96 "Accounting for Income Taxes" ("SFAS 96") to address the increased complexity and significance of deferred taxes in the balance sheet. However, because of its complex scheduling process and conservative tax asset provisions, SFAS 96 soon became a source of controversy among businesses, CPA firms, professional organizations, and industry trade groups. In response to the criticism, the FASB deferred the required implementation date of SFAS 96 three times (SFAS 100, 103, and 108 ) and began developing a new standard which would address not only criticism of APB Opinion 11 but also the controversy surrounding SFAS 96. The new standard, SFAS 109, "Accounting for Income Taxes," became effective for periods beginning after December 15, 1992.

The objective of accounting for income taxes is the recognition and presentation in the financial statements of the following:

- Taxes currently payable or refundable

- Deferred tax assets and liabilities for the future tax consequences of events that have been recognized in the financial statements or tax returns.

Deferred taxes reflect the future tax consequences of events already recognized in either the financial statements or tax returns. SFAS 109 uses the balance sheet approach, also referred to as the liability method, to determine deferred taxes. This method, first introduced in SFAS 96, differs from APB 11, which used the income statement approach. SFAS 109 also requires a deferred tax asset to be recognized for deductible temporary differences and operating loss and tax credit carryforwards using the applicable tax rate.

The income statement approach recognizes deferred taxes on the temporary timing differences between pretax accounting income and taxable income each year. Temporary differences are those differences between accounting and taxable income that will ultimately reverse. For example, intangible drilling costs for a successful well are expensed when paid for tax purposes, but capitalized and depreciated for accounting purposes. If we assume intangible drilling costs of $\$ 100,000$ was the sole timing difference, and this cost was depreciated $\$ 20,000$ per year for accounting purposes, there would be an $\$ 80,000$ temporary timing difference in year one, as taxable income would be less than accounting income. This timing difference would reverse $\$ 20,000$ each year as the intangible drilling cost is depreciated for accounting purposes with no deduction for tax purposes. At the end of the fifth year, the timing difference would be completely reversed.

The liability approach recognizes deferred taxes on the temporary differences between the financial and tax bases of assets and liabilities. Both the deferred tax liability and the deferred tax asset must be measured by use of the 
applicable tax rate. The applicable tax rate is the enacted tax rate to be applied to the last dollar of taxable income for the year when the liability is expected to be settled or the assets recovered. A single flat tax rate may be used for companies for which graduated rates are not a significant factor. A deferred tax asset is recognized for existing alternative minimum tax credit carryforwards for tax purposes. When computing deferred tax assets and/or liabilities, if there is a change in the tax rate or tax law, the deferred tax assets and/or liabilities should be adjusted in the period that includes the enactment date. To the extent deferred tax balances are adjusted for the effects of such changes, income tax expense or benefit from continuing operations is charged or credited. Using the example from the preceding paragraph, the financial statement basis of the intangible drilling cost in year one would be $\$ 80,000$ $(\$ 100,000$ less $\$ 20,000$ depreciation), while there would be no basis for tax purposes because the costs were totally deducted. Deferred taxes would be provided for the $\$ 80,000$ difference by use of enacted tax rates. Deferred taxes would be adjusted each year until the difference between the financial accounting and tax bases was fully eliminated at the end of year five.

Once deferred tax assets and liabilities relating to the future tax consequences of temporary differences and carryforwards have been measured, the deferred tax provision or benefit is based on the net change in a deferred tax balance during the year. The income tax expense or benefit for the period is derived from the total tax currently payable or refundable and the deferred tax expense or benefit.

As stated earlier, SFAS 109 became effective for fiscal years beginning after December 15, 1992. There were two transition options available when adopting SFAS 109: prospective or retroactive application. A company could elect to restate the financial statements for any number of consecutive prior years (retroactive application) or report a cumulative effect adjustment below "income from continuing operations" (prospective application).

For 1993 through 1995, all FRS companies have reported taxes in accordance with SFAS 109. For 1992, seventeen FRS reporting companies had adopted the provisions of SFAS 109 , which resulted in a net $\$ 163$ million benefit to their 1992 reported earnings. The remaining eight FRS reporting companies adopted SFAS 109 in the first quarter of 1993, resulting in a $\$ 671$ million benefit to 1993 reported earnings. Of the eight companies which had not adopted SFAS 109 in 1992, five reported under APB 11 and three reported in accordance with SFAS 96.

\section{Corporate Acquisitions}

Under FRS reporting rules, no acquisitions are accounted for under the pooling of interest method. This is because, under the pooling method, the financial statements do not reflect such transactions as new investment, since the historical financial statements are restated. One of the objectives of the FRS is to track new investment activities.

For FRS reporting purposes, acquisitions accounted for as pooling for annual report purposes must be reflected in the FRS filing under a modified purchase method. All purchase accounting rules are followed, except that the assets of the acquired company are not revalued but are recorded at their book values as stated on the acquired company's books.

\section{Full Cost and Successful Efforts Accounting Methods}

FRS reporting companies are permitted to choose between two accounting methods, "full cost" and "successful efforts," to account for their exploration and production activities. All but two of the FRS companies use the successful efforts method. The main difference between the two methods is the treatment of dry exploratory well cost.

Under full cost, the cost of a dry exploratory well is capitalized and then amortized to the income statement over the productive life of successful wells. Thus, the costs of both dry and successful wells are capitalized and reflected in the balance sheet as part of producing properties.

Under successful efforts, the cost of a dry exploratory well is written off to expense in the year in which drilling is determined to be unsuccessful. There is no capitalized cost of such dry exploratory wells carried on the balance sheet.

In comparison to the successful efforts method, the full cost method will: (1) show less volatility of earnings, since the cost of unsuccessful wells is amortized over many years; (2) show a higher balance in accumulated property, plant, and equipment (PP\&E), since the account contains the costs of all wells drilled, including dry exploratory wells; (3) usually show higher earnings during years of intense exploratory activity when a number of dry wells are encountered; and (4) show the same cumulative earnings over a long period of years, since eventually all cost will be amortized to the income statement. These effects are minimized if the firm is large, since the exploratory activities of a large firm are usually smaller 
relative to total production operations than they are in a small production firm.

Usually, the precise effect of using one method over the other cannot be determined. However, one large firm switched from full cost to successful efforts in 1975 and restated 1973 and 1974 data to the successful efforts method. Thus, we have available the impact of this conversion on their comparative net income, net PP\&E, and return on net PP\&E for 1973 and 1974 (see Table A3). Since twenty-two of the FRS companies presently use successful efforts accounting, comparability problems are inconsequential.

\section{Inventory Accounting - LIFO Versus FIFO}

The Last In-First Out (LIFO) and the First In-First Out (FIFO) inventory methods are used most often in the preparation of the financial statements of industrial enterprises.

Under FIFO, the balance sheet valuation of inventory is based upon the most recent prices paid for the physical units on hand at year's end, and the income statement reflects the cost of units sold at the oldest unit cost. In periods of rapidly rising prices, the income statement reflects higher profits than would be reflected if the units sold were priced at current replacement cost or under the LIFO method.

Under LIFO, the balance sheet valuation of inventory is based on the prices paid for the first units of each major type of inventory ever purchased. For example, crude oil could be carried at $\$ 10$ per barrel, an amount which vastly understates the value of the inventory in terms of its replacement cost. The income statement reflects the cost of units sold at the most recent prices paid for the number of units sold. Thus, cost of goods sold reflects nearly a replacement cost amount, and profits are lower than under the FIFO method.
Since either method is permitted under the Federal tax laws, most companies use LIFO for operations subject to U.S. taxation because earnings and, hence, taxes are lower under this method. By 1979, most FRS reporting companies were using primarily the LIFO inventory method. Most analysts probably would agree that LIFO is the preferable method, since the income statement is more realistic than with FIFO. However, its disadvantage is that the balance sheet's inventory figure is understated, and hence the stockholders' equity amount is correspondingly understated.

In 1995, two FRS companies reported liquidation profits or losses. The 1995 aggregate liquidation profits increased the reporting companies' operating income by $\$ 163$ million, an amount which represented 0.5 percent of their aggregate operating income. This compares to a $\$ 23.4$ million increase in 1994 and a $\$ 96$ million increase in 1993, amounts that represented 0.1 and 0.4 percent, respectively, of aggregate operating income for those years.

\section{Foreign Currency Translations}

In December 1981, the Financial Accounting Standards Board (FASB) issued Statement No. 52, "Foreign Currency Translations," which superseded FASB-8, "Accounting for the Translation of Foreign Currency Transactions and Foreign Currency Financial Statements." FASB-52 covers the translation of foreign currency financial statements for the purposes of the consolidation, combination, or reporting by the equity method, and the translation of foreign currency transactions. The new statement required that assets, liabilities, and operations of an entity be stated in the currency of the primary economic environment in which the entity operates (termed the "functional currency"). If a foreign entity has not kept its financial records in the functional currency, remeasurement is required prior to translation. Any gain or loss on remeasurement is recognized in current net income. The assets and liabilities of the foreign entity are translated

Table A3. A Comparison Between Full Cost and Successful Efforts Accounting Methods

\begin{tabular}{|c|c|c|}
\hline Years & Full Cost & Successful Efforts \\
\hline \multicolumn{3}{|l|}{1973} \\
\hline Net Income (dollars) & $1,292,400$ & $1,243,300$ \\
\hline Net PP\&E (dollars) $\ldots \ldots \ldots \ldots \ldots \ldots \ldots$ & $8,476,700$ & $7,511,300$ \\
\hline Net Income/PP\&E (percent) $\ldots \ldots \ldots \ldots \ldots$ & 15.25 & 16.70 \\
\hline \multicolumn{3}{|l|}{1974} \\
\hline Net Income (dollars) & $1,586,400$ & $1,544,700$ \\
\hline Net PP\&E (dollars) $\ldots \ldots \ldots \ldots \ldots \ldots \ldots$ & $9,593,300$ & $8,563,500$ \\
\hline Net Income/PP\&E (percent) $\ldots \ldots \ldots \ldots \ldots \ldots$ & 16.54 & 17.98 \\
\hline
\end{tabular}

Source: Texaco, Inc., 1974 and 1977 Annual Report and Statistical Supplements. 
from its functional currency to the reporting currency at the current rate of exchange.

Under FASB-52, gain or loss on the translation of foreign currency financial statements is shown as a separate component of stockholders' equity, whereas, under FASB8 , all non-monetary balance sheet items were translated at the historical rate of exchange. Thus, the change to FASB52 , which uses the current rate of exchange, had the most significant impact on inventories and fixed assets. With respect to the income statement, FASB-52 requires that only gains or losses from foreign currency transactions be included.

As Table A4 indicates, foreign currency translation gains increased stockholders' equity by 0.4 percent, while foreign currency transaction losses decreased pretax income by 0.1 percent in 1995.

\section{FRS Database History}

The Form EIA-28, Financial Reporting System (FRS), database has existed in three formats during its 22-year history. In addition, there have been minor, periodic adjustments since 1987. The most noteworthy was the change from a Statement of Sources and Uses of Funds to a Statement of Cash Flows, effective in the 1986 reporting year. The first version of the Form EIA-28 and its database covered years 1974-1980. The second version covered years 1981-1986. The third covered years 1987-1992. The fourth version begins with the 1993 reporting year and is approved through the 1995 reporting year.

The current version was changed by the addition of the Former Soviet Union and Eastern Europe as a new geographical reporting area.
The first full reporting year for the first version of the form was 1977. It consisted of 47 separate schedules containing 8,775 data elements and was 136 pages long. ${ }^{208}$ This version of the database contained a significant amount of detail at the consolidated level, in each line of business, and in the breadth of operating statistics. However, not all of the collected data were loaded into the database. About 1,000 elements were not unique to individual companies-such as joint venture information-and were maintained only in their hard copy format.

In 1982 (for the 1981 reporting year), the form was shortened by 72 percent, to 2,468 elements. The format was still the same, with data collected at the consolidated level, four energy lines of business (petroleum, coal, nuclear, and other energy) and nonenergy. The 1981-1986 form consisted of 19 schedules and was 35 pages long. Although data were still collected by each line of business, most of the decline was at the line-of-business level, where more than 81 percent of the form was eliminated, compared with a 58-percent decline at the consolidated level.

In 1988 (for the 1987 reporting year) the form was shortened by another 33 percent, to 1,650 elements. The consolidated level was shortened by 32 percent, primarily by combining other energy with nuclear energy. Petroleum data declined by 10 percent, coal by 74 percent, and separate income statement schedules for the remaining lines of business (coal, nuclear and other energy, and nonenergy) were eliminated altogether (although income statements for each of these lines of business were incorporated into Schedule 5110, Consolidating Statement of Income). The form currently has 14 schedules and is 27 pages long.

\footnotetext{
${ }^{208}$ In order to extend the range of the data back through 1974, an abbreviated version of the form was collected for the years 1974 through 1976 . Almost 2,900 data elements (one-third of the total) were collected for each of these years, and consisted primarily of summary data from 26 of the 47 schedules.
} 
Table A4. The Impact of FASB-52, Foreign Currency Translations, on Stockholders' Equity and Pretax Income, 1982-1995

\begin{tabular}{|c|c|c|c|c|c|c|}
\hline Year & $\begin{array}{c}\text { Translation } \\
\text { Gains/Losses }\end{array}$ & $\begin{array}{c}\text { Stockholders' } \\
\text { Equity }\end{array}$ & $\begin{array}{c}\text { Percent of } \\
\text { Stockholders' } \\
\text { Equity }\end{array}$ & $\begin{array}{c}\text { Transaction } \\
\text { Gains/Losses }\end{array}$ & $\begin{array}{l}\text { Pretax } \\
\text { Income }\end{array}$ & $\begin{array}{l}\text { Percent of } \\
\text { Pretax } \\
\text { Income }\end{array}$ \\
\hline & \multicolumn{2}{|c|}{ (million dollars) } & & \multicolumn{2}{|c|}{ (million dollars) } & \\
\hline $1982 \ldots \ldots \ldots$ & $-1,764$ & 183,933 & -1.0 & -111 & 45,157 & -0.2 \\
\hline 1983 & $-1,253$ & 192,509 & -0.7 & 35 & 47,420 & 0.1 \\
\hline 1984 & $-1,683$ & 176,461 & -1.0 & -44 & 47,609 & -0.1 \\
\hline $1985 \ldots \ldots$ & 399 & 165,457 & 0.2 & 176 & 43,573 & 0.4 \\
\hline $1986 \ldots$ & 1,786 & 164,601 & 1.1 & 543 & 20,564 & 2.6 \\
\hline $1987 \ldots$ & 3,425 & 165,458 & 2.1 & 176 & 25,006 & 0.7 \\
\hline $1988 \ldots$ & -495 & 164,832 & -0.3 & 89 & 34,285 & 0.3 \\
\hline $1989 \ldots$ & -465 & 160,638 & -0.3 & 142 & 32,281 & 0.4 \\
\hline $1990 \ldots$ & 1,918 & 167,060 & 1.1 & 135 & 37,489 & 0.4 \\
\hline $1991 \ldots$ & 101 & 167,574 & 0.1 & -25 & 25,120 & -0.1 \\
\hline $1992 \ldots \ldots$ & $-3,341$ & 157,295 & -2.1 & 375 & 22,542 & 1.7 \\
\hline $1993 \ldots$ & -637 & 161,769 & -0.4 & 170 & 24,777 & 0.7 \\
\hline $1994 \ldots \ldots$ & 1,912 & 165,689 & 1.2 & 280 & 29,592 & 1.0 \\
\hline $1995 \ldots \ldots$ & 701 & 166,689 & 0.4 & -48 & 34,233 & -0.1 \\
\hline
\end{tabular}

Source: Energy Information Administration, Form EIA-28. 

Appendix B

Detailed Statistical

Tables 



\section{Appendix B}

\section{Detailed Statistical Tables}

Table B1. Selected U.S. Operating Statistics for FRS Companies and U.S. Industry, 1994 and 1995

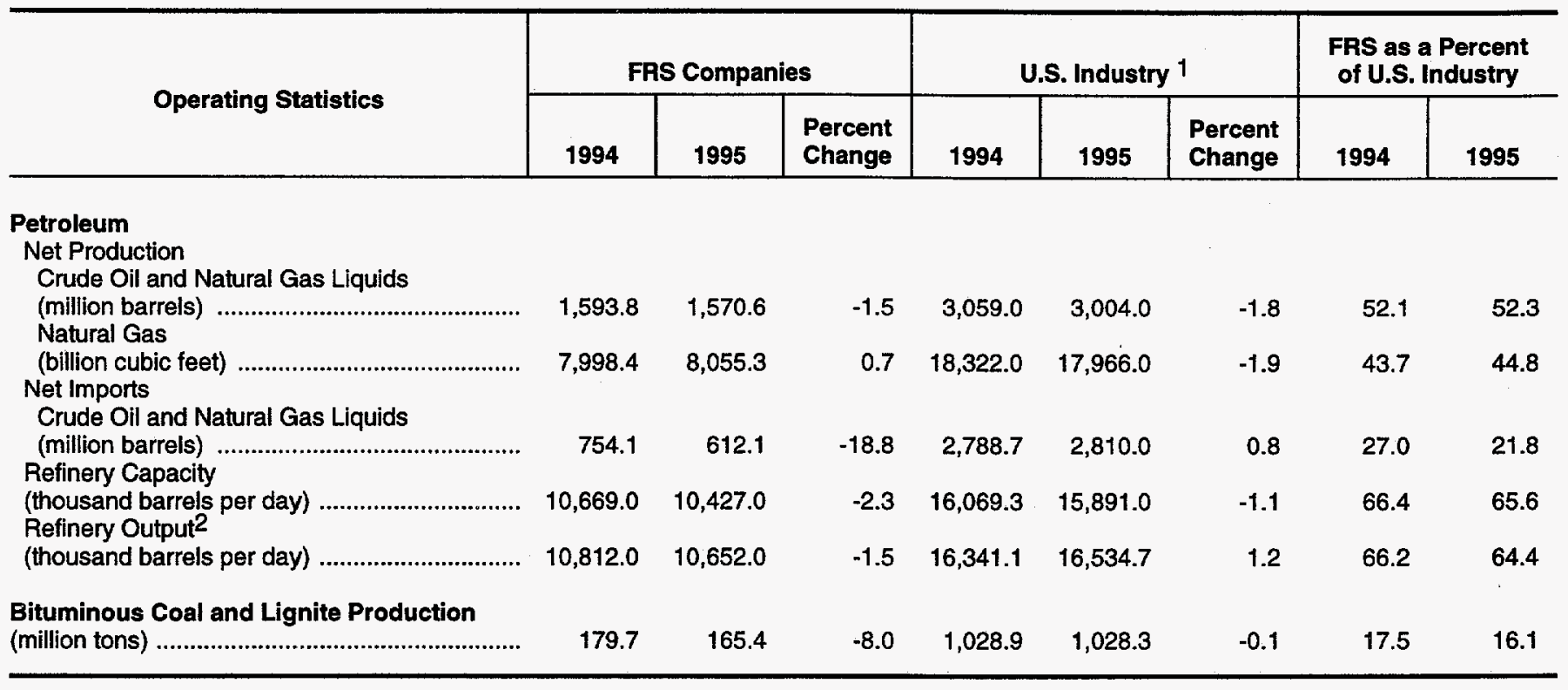

1 U.S. area is defined to include the 50 States, District of Columbia, U.S. Virgin Islands, and Puerto Rico.

2 For FRS companies, includes refinery output at own refineries for own account and at others' refineries for own account.

Note: The data for total U.S. production of crude oil and natural gas liquids and natural gas (dry) utilized in this report are taken from Energy Information Administration, Form EIA-23; see U.S. Crude Oil, Natural Gas, and Natural Gas Liquids Reserves 1995 Annual Report (December 1996). This source is utilized in order to preserve consistency between production reported in the context of oil and gas reserves and reserve additions and production reported elsewhere in this report. However, the official Energy Information Administration U.S. totals for crude oil and natural gas plant production are 3,148.5 million barrels in 1995 and 3,155.4 million barrels in 1994. (See Energy Information Administration, Petroleum Supply Annual 1995, Volume 1 (May 1996), p. 2.) For dry natural gas production, the official Energy Information Administration U.S. totals are 18,804 billion cubic feet in 1995 and 18,747 billion cubic feet in 1994. (See Energy Information Administration, Natural Gas Monthly, September 1996, p. 8.)

Sources: Industry data - Petroleum net production: Energy Information Administration, Form ElA-23; see U.S. Crude Oil, Natural Gas, and Natural Gas Liquids Reserves, 1995 Annual Report (December 1996). Net imports: data compiled for the International Energy Agency by the Petroleum Supply Division, Office of Oil and Gas, Energy Information Administration. Refinery capacity and refinery output: Energy Information Administration, Forms EIA-820 and EIA-810; see Petroleum Supply Annual, 1994 and 1995. Coal production: Energy Information Administration, Form EIA-7A; see Coal Industry Annual 1995 (October 1996). 
Table B2. Selected U.S. Operating Statistics for FRS Companies and U.S. Industry, 1989-1995

\begin{tabular}{|c|c|c|c|c|c|c|c|}
\hline Operating Statistics & 1989 & 1990 & 1991 & 1992 & 1993 & 1994 & 1995 \\
\hline \multicolumn{8}{|l|}{$\begin{array}{l}\text { Petroleum } \\
\text { Net Production } \\
\text { Crude Oil and Natural Gas Liquids } \\
\text { (million barrels) }\end{array}$} \\
\hline 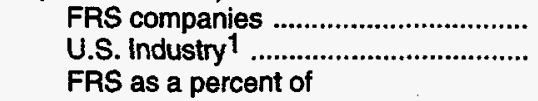 & $\begin{array}{l}1,911.1 \\
3,317.0\end{array}$ & $\begin{array}{l}1,814.0 \\
3,237.0\end{array}$ & $\begin{array}{l}1,818.1 \\
3,266.0\end{array}$ & $\begin{array}{l}1,750.2 \\
3,219.0\end{array}$ & $\begin{array}{l}1,632.5 \\
3,127.0\end{array}$ & $\begin{array}{l}1,593.8 \\
3,059.0\end{array}$ & $\begin{array}{l}1,570.6 \\
3,004.0\end{array}$ \\
\hline $\begin{array}{l}\text { U.S. Industry } \\
\text { Natural Gas } \\
\text { (billion cubic feet) }\end{array}$ & 57.6 & 56.0 & 55.7 & 54.4 & 52.2 & 52.1 & 52.3 \\
\hline 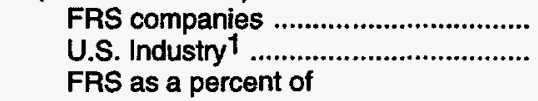 & $\begin{array}{r}7,480.7 \\
16,983.0\end{array}$ & $\begin{array}{r}7,578.2 \\
17,233.0\end{array}$ & $\begin{array}{r}7,509.5 \\
17,202.0\end{array}$ & $\begin{array}{r}7,877.7 \\
17,423.0\end{array}$ & $\begin{array}{r}7,651.1 \\
17,789.0\end{array}$ & $\begin{array}{r}7,998.4 \\
18,322.0\end{array}$ & $\begin{array}{r}8,055.3 \\
17,966.0\end{array}$ \\
\hline $\begin{array}{l}\text { U.S. Industry } \\
\text { Net Imports } \\
\text { Crude Oil and Natural Gas Liquids } \\
\text { (million barrels) }\end{array}$ & 44.0 & 44.0 & 43.7 & 45.2 & 43.0 & 43.7 & 44.8 \\
\hline 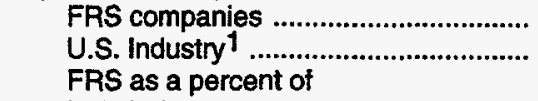 & $\begin{array}{r}834.3 \\
2,289.3\end{array}$ & $\begin{array}{r}975.2 \\
2,324.7\end{array}$ & $\begin{array}{r}917.9 \\
2,243.7\end{array}$ & $\begin{array}{r}868.8 \\
2,383.0\end{array}$ & $\begin{array}{r}757.5 \\
2,640.9\end{array}$ & $\begin{array}{r}754.1 \\
2,788.7\end{array}$ & $\begin{array}{r}612.1 \\
2,810.0\end{array}$ \\
\hline $\begin{array}{l}\text { U.S. Industry } \\
\text { Refinery Capacity } \\
\text { (thousand barrels per day) }\end{array}$ & 36.4 & 41.9 & 40.9 & 36.5 & 28.7 & 27.0 & 21.8 \\
\hline $\begin{array}{l}\text { FRS companies } \\
\text { U.S. Industry }{ }^{1} \ldots \ldots \ldots \ldots \\
\text { FRS as a percent of }\end{array}$ & $\begin{array}{l}11,489.0 \\
16,238.0\end{array}$ & $\begin{array}{l}11,372.0 \\
16,430.4\end{array}$ & $\begin{array}{l}11,203.0 \\
16,452.6\end{array}$ & $\begin{array}{l}10,952.0 \\
15,804.4\end{array}$ & $\begin{array}{l}10,714.0 \\
15,718.0\end{array}$ & $\begin{array}{l}10,669.0 \\
16,069.3\end{array}$ & $\begin{array}{l}10,427.0 \\
15,891.0\end{array}$ \\
\hline $\begin{array}{l}\text { U.S. Industry } \\
\text { Refinery Output } 2 \\
\text { (thousand barrels per day) }\end{array}$ & 70.8 & 69.2 & 68.1 & 69.3 & 68.2 & 66.4 & 65.6 \\
\hline $\begin{array}{l}\text { FRS companies } \\
\text { U.S. Industry } 1 \\
\text { FRS as a percent of }\end{array}$ & $\begin{array}{l}11,413.0 \\
15,654.6\end{array}$ & $\begin{array}{r}11,312.0 \\
15,911.2\end{array}$ & $\begin{array}{l}11,122.0 \\
15,872.2\end{array}$ & $\begin{array}{l}10,994.0 \\
15,932.0\end{array}$ & $\begin{array}{l}10,822.0 \\
16,341.2\end{array}$ & $\begin{array}{l}10,812.0 \\
16,341.1\end{array}$ & $\begin{array}{l}10,652.0 \\
16,534.7\end{array}$ \\
\hline 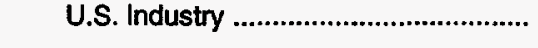 & 72.9 & 71.1 & 70.1 & 69.0 & 66.2 & 66.2 & 64.4 \\
\hline \multicolumn{8}{|l|}{$\begin{array}{l}\text { Bituminous Coal and Lignite } \\
\text { Production } \\
\text { (million tons) }\end{array}$} \\
\hline 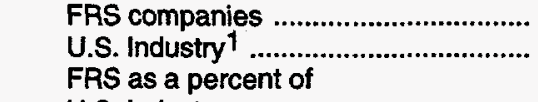 & $\begin{array}{l}286.9 \\
980.7\end{array}$ & $\begin{array}{r}282.0 \\
1,029.1\end{array}$ & $\begin{array}{l}289.6 \\
996.0\end{array}$ & $\begin{array}{l}251.9 \\
994.1\end{array}$ & $\begin{array}{l}197.3 \\
941.1\end{array}$ & $\begin{array}{r}179.7 \\
1,028.9\end{array}$ & $\begin{array}{r}165.4 \\
1,028.3\end{array}$ \\
\hline 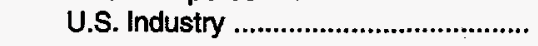 & 29.3 & 27.4 & 29.1 & 25.3 & 21.0 & 17.5 & 16.1 \\
\hline
\end{tabular}

1 U.S. area is defined to include the 50 States, District of Columbia, U.S. Virgin Islands, and Puerto Rico.

2 For FRS companies, includes refinery output at own refineries for own account and at others' refineries for own account.

Note: The data for total U.S. production of crude oll and natural gas liquids and natural gas (dry) utilized in this report are taken from Energy Information Administration, Form ElA-23; see U.S. Crude Oil, Natural Gas, and Natural Gas Liquids Reserves 1995 Annual Report (December 1996). This source is utilized in order to preserve consistency between production reported in the context of oil and gas reserves and reserve additions and production reported elsewhere in this report. However, the official Energy Information Administration U.S. totals for crude oil and natural gas plant production are 3,148.5 million barrels in 1995 and 3,155.4 million barrels in 1994. (See Energy Information Administration,

Petroleum Supply Annual 1995, Volume 1 (May 1996), p. 2.) For dry natural gas production, the official Energy Information Administration U.S. totals are 18,804 billion cubic feet in 1995 and 18,747 billion cubic feet in 1994. (See Energy Information Administration, Natural Gas Monthly, September 1996, p. 8.)

Sources: Industry data - Petroleum net production: Energy Information Administration, Form ElA-23; see U.S. Crude Oil, Natural Gas, and Natural Gas Liquids Reserves, 1995 Annual Report (December 1996). Net imports: data compiled for the International Energy Agency by the Petroleum Supply Division, Office of Oil and Gas, Energy Intormation Administration. Refinery capacity and refinery output: Energy Information Administration, Forms EIA-820 and EIA-810; see Petroleum Supply Annual, 1994 and 1995. Coal production: Energy Information Administration, Form EIA-7A; see Coal Industry Annual 1995 (October 1996). 
Table B3. A Comparison of Selected Financial Items for FRS Companies and the S\&P 400, 1995 and Percent Change from 1994

\begin{tabular}{|c|c|c|c|c|}
\hline \multirow[b]{2}{*}{ Selected Financial Items } & \multicolumn{2}{|c|}{ FRS Companies } & \multicolumn{2}{|c|}{ S\&P 400} \\
\hline & $\begin{array}{c}1995 \\
\text { (billion dollars) }\end{array}$ & $\begin{array}{l}\text { Percent Change } \\
\text { from } 1994\end{array}$ & $\begin{array}{c}1995 \\
\text { (billion dollars) }\end{array}$ & $\begin{array}{l}\text { Percent Change } \\
\text { from } 1994\end{array}$ \\
\hline \multicolumn{5}{|l|}{ Income Statement } \\
\hline 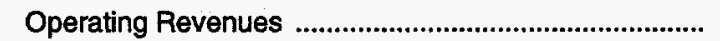 & 481.6 & 7.9 & $3,307.6$ & 7.3 \\
\hline Operating Expenses & -449.1 & 7.8 & $-2,945.7$ & 6.3 \\
\hline Operating Income & 32.5 & 8.1 & 361.9 & 16.2 \\
\hline Other Income ${ }^{1}$ & 1.3 & $(2)$ & -86.8 & 72.2 \\
\hline 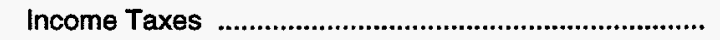 & -12.8 & 19.9 & -105.3 & 9.1 \\
\hline Net Income & 21.1 & 27.7 & 169.8 & 3.2 \\
\hline \multicolumn{5}{|l|}{ Cash Flows from Operations 3} \\
\hline Net Income & 21.1 & 27.7 & 169.8 & 3.2 \\
\hline Other Items, Net 4 & 37.4 & 17.7 & 197.2 & 20.2 \\
\hline 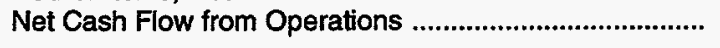 & 58.5 & 21.1 & 367.0 & 11.7 \\
\hline \multicolumn{5}{|l|}{ Cash Flows from Investing Activities 3} \\
\hline Additions to PP\&E & -44.5 & 18.7 & -242.8 & 11.9 \\
\hline 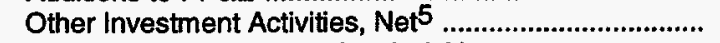 & 9.9 & 298.3 & -72.1 & 2.8 \\
\hline 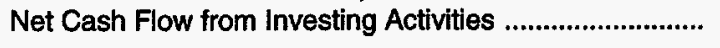 & -34.6 & -1.3 & -314.9 & 9.7 \\
\hline \multicolumn{5}{|l|}{ Cash Flows from Financing Activities 3} \\
\hline 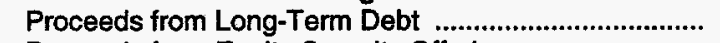 & 19.9 & 59.4 & 230.8 & 28.7 \\
\hline Proceeds from Equity Security Offerings ............................. & 3.5 & 32.8 & 19.8 & -20.6 \\
\hline 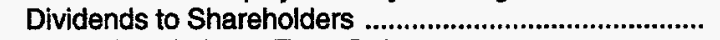 & -15.2 & 2.2 & -76.0 & 5.0 \\
\hline 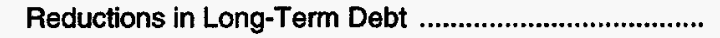 & -18.7 & 35.6 & -153.9 & -4.9 \\
\hline Stock Repurchases & -10.0 & 893.6 & -56.7 & 88.0 \\
\hline 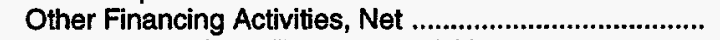 & -2.4 & 115.4 & -1.4 & $\left({ }^{2}\right)$ \\
\hline Net Cash Flow from Financing Activities .......................... & -22.9 & 46.2 & -37.4 & -7.2 \\
\hline Effect of Exchange Rate Changes on Cash ................. & 0.0 & -89.3 & 0.7 & -46.3 \\
\hline Increase (Decrease) in Cash and Cash Equivalents .. & 1.1 & $\left(^{2}\right)$ & 15.4 & $(2)$ \\
\hline
\end{tabular}

1 "Other Income" includes other revenue and expense, discontinued operations, extraordinary items, and accounting changes.

2 Not meaningful.

3 Items that add to cash are positive, and items that use cash are shown as negative values.

4 "Other Items, Net" includes: DD\&A, deferred taxes, dry hole expense, minority interest, recognized undistributed earnings/(losses) of unconsolidated affiliates, (gain)/loss on disposition of PP\&E, changes in operating assets and liabilities, and other noncash items, excluding net change in short-term debt; other cash items, net.

5 "Other Investment Activities, Net" includes additions to investments and advances and proceeds from disposals of PP\&E.

Sources: Standard \& Poor's (S\&P) 400 data - Compustat, Inc. FRS companies' data - Energy Information Administration, Form EIA-28. 
Table B4. Consolidating Statement of Income for FRS Companies, 1995

(Million Dollars)

\begin{tabular}{|c|c|c|c|c|c|c|}
\hline Income Statement Items & Consolidated & $\begin{array}{c}\text { Eliminations } \\
\text { \& Non- } \\
\text { Traceable }\end{array}$ & Petroleum & Coal & $\begin{array}{l}\text { Nuclear } \\
\text { \& Other } \\
\text { Energy }\end{array}$ & $\begin{array}{c}\text { Non- } \\
\text { Energy }\end{array}$ \\
\hline \multicolumn{7}{|l|}{ Operating Expenses } \\
\hline General Operating Expenses .................... & 401,250 & $-9,795$ & 334,508 & 2,572 & 977 & 72,988 \\
\hline Total Operating Expenses ................................ & 449,090 & $-5,571$ & 369,579 & 3,167 & 1,270 & 80,645 \\
\hline Operating Income & 32,536 & $-4,779$ & 21,324 & 341 & 138 & 15,512 \\
\hline \multicolumn{7}{|l|}{ Other Revenue \& (Expense) } \\
\hline Eamings of Uniconsolidated Affiliates ...... & 4,721 & 154 & 2,888 & $w$ & $w$ & 1,485 \\
\hline Other Dividend \& Interest Income ............. & 1,640 & 1,640 & - & - & - & - \\
\hline Other Revenue \& (Expense) ..................... & 2,072 & 2,072 & - & - & - & - \\
\hline Total Other Revenue \& (Expense) .............. & 1,697 & $-5,023$ & 3,871 & 86 & 135 & 2,628 \\
\hline 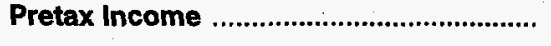 & 34,233 & $-9,802$ & 25,195 & 427 & 273 & 18,140 \\
\hline 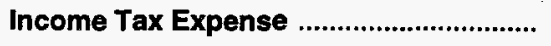 & 12,751 & $-3,222$ & 10,288 & 87 & 100 & 5,498 \\
\hline Discontinued Operations ................................ & W & W & W & W & 0 & 0 \\
\hline \multicolumn{7}{|l|}{ Extraordinary Items and Cumulative } \\
\hline Effect of Accounting Changes ................. & W & W & W & $\mathbf{W}$ & 0 & 0 \\
\hline Net Income & 21,131 & $-6,681$ & 14,686 & 311 & 173 & 12,642 \\
\hline
\end{tabular}

$\bar{w}=$ Not available.

$W=$ Data withheld to avoid disclosure.

Source: Energy Information Administration, Form EIA-28. 
Table B5. Consolidating Statement of Income for FRS Companies, U.S. and Foreign Petroleum Segments, 1995

(Million Dollars)

\begin{tabular}{|c|c|c|c|c|c|c|c|c|}
\hline Income Statement Items & $\begin{array}{l}\text { Consoli- } \\
\text { dated }\end{array}$ & Production & $\begin{array}{l}\text { Refining/ } \\
\text { Marketing }\end{array}$ & Pipelines & $\begin{array}{l}\text { Consoli- } \\
\text { dated }\end{array}$ & Production & $\begin{array}{l}\text { Refining/ } \\
\text { Marketing }\end{array}$ & $\begin{array}{c}\text { Int'l } \\
\text { Marine }\end{array}$ \\
\hline \multicolumn{9}{|l|}{ Operating Revenues } \\
\hline Raw Material Sales .. & 81,609 & 44,999 & 65,164 & 1,356 & 56,985 & 40,474 & 45,588 & \\
\hline Refined Products Sales ........................ & 120,313 & & 120,698 & & 124,617 & w & 124,615 & W \\
\hline Other & 9,570 & 1,508 & 7,149 & 145 & 4,307 & 970 & 3,349 & \\
\hline Total Operating Revenues ..................... & 219,625 & 47,296 & 197,008 & 9,857 & 189,065 & 42,286 & 174,940 & 2,150 \\
\hline \multicolumn{9}{|l|}{ Operating Expenses } \\
\hline General Operating Expenses .............. & 188,420 & 28,206 & 189,133 & 5,611 & 163,874 & 22,826 & 169,216 & 2,052 \\
\hline DD\&A & 19,371 & 13,697 & 4,732 & 942 & 9,772 & 7,751 & 1,891 & 130 \\
\hline 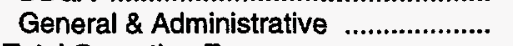 & 3,760 & 1,108 & 2,150 & 508 & 2,169 & 854 & 1,368 & 38 \\
\hline \multicolumn{9}{|l|}{ Other Revenue \& (Expense) } \\
\hline Earnings of Unconsolidated Affiliates & 438 & 95 & -148 & 491 & 2,450 & 1,561 & 887 & $w$ \\
\hline Gain(Loss) On Disposition of PP\&E ... & 662 & 437 & 105 & 120 & 321 & 190 & 112 & W \\
\hline Total Other Revenue \& (Expense) ....... & 1,100 & 532 & -43 & 611 & 2,771 & 1,751 & 999 & $\ddot{W}$ \\
\hline Pretax Income & 9,174 & 4,817 & 950 & 3,407 & 16,021 & 12,606 & 3,464 & -49 \\
\hline 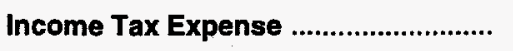 & 2,583 & 976 & 371 & 1,236 & 7,705 & 6,661 & 1,055 & -11 \\
\hline Discontinued Operations ......................... & w & $w$ & W & $w$ & $w$ & $w$ & 0 & 0 \\
\hline $\begin{array}{l}\text { Extraordinary Items and Cumulative } \\
\text { Effect of Accounting Changes ........... }\end{array}$ & $w$ & $w$ & W & W & $w$ & $w$ & 0 & 0 \\
\hline
\end{tabular}

$W=$ Data withheld to avoid disclosure.

Source: Energy Information Administration, Form EIA-28. 
Table B6. Profit Rates for Lines of Business and Petroleum Segments for FRS Companies, 1989-1995

(Percent)

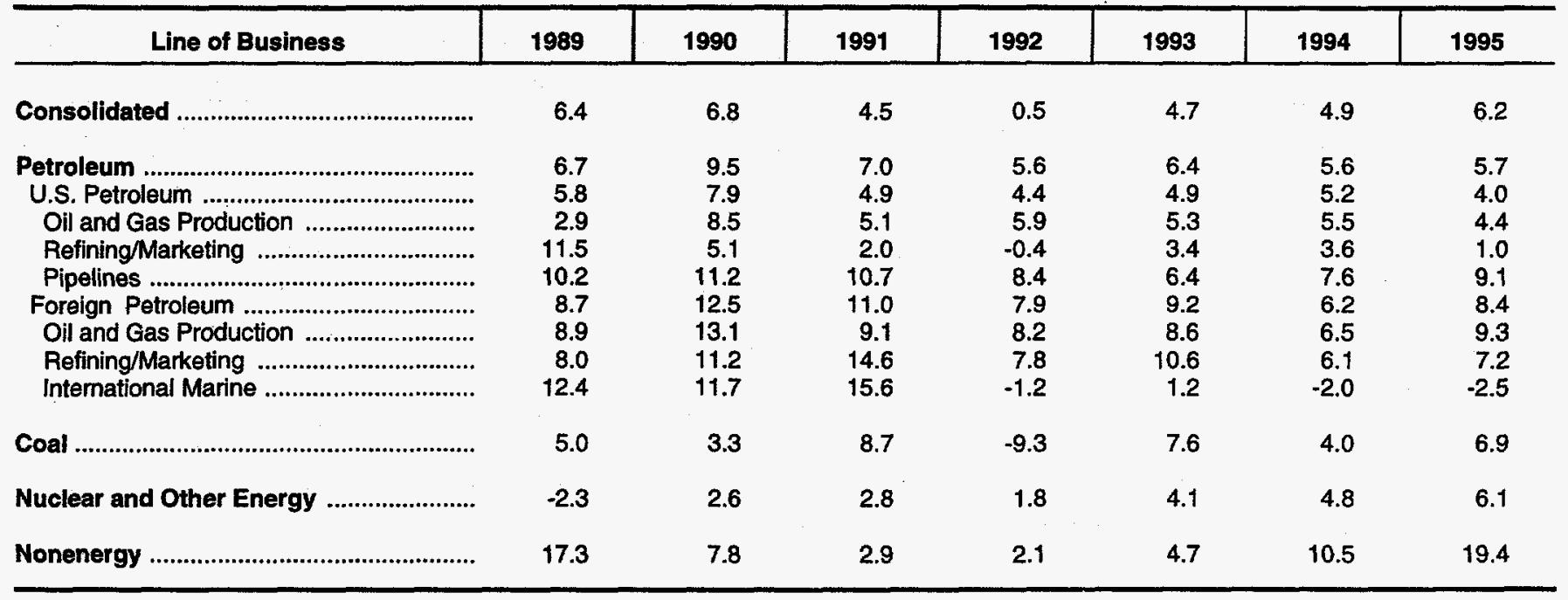

Note: Profit rate measured as contribution to net income/net investment in place.

Source: Energy Information Administration, Form EIA-28. 
Table B7. Profit Rates for Petroleum Segments for FRS Companies Ranked by Total Energy Assets, 1993-1995

(Percent)

\begin{tabular}{|c|c|c|c|c|c|c|c|c|c|}
\hline \multirow{2}{*}{ Petroleum Segments } & \multicolumn{3}{|c|}{ Top Four } & \multicolumn{3}{|c|}{ Five Through Twelve } & \multicolumn{3}{|c|}{ All Other } \\
\hline & 1993 & 1994 & 1995 & 1993 & 1994 & 1995 & 1993 & 1994 & 1995 \\
\hline 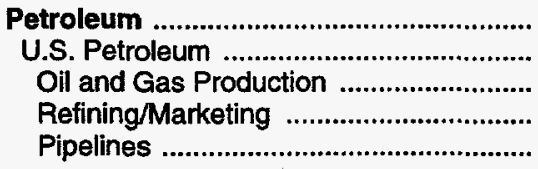 & $\begin{array}{r}8.1 \\
4.5 \\
5.5 \\
1.5 \\
13.1\end{array}$ & $\begin{array}{r}6.5 \\
5.0 \\
5.9 \\
2.1 \\
17.1\end{array}$ & $\begin{array}{r}6.6 \\
3.1 \\
3.2 \\
0.8 \\
20.0\end{array}$ & $\begin{array}{l}4.9 \\
5.2 \\
4.4 \\
7.4 \\
4.8\end{array}$ & $\begin{array}{l}5.0 \\
5.5 \\
5.4 \\
5.4 \\
5.9\end{array}$ & $\begin{array}{l}5.7 \\
5.8 \\
5.8 \\
4.8 \\
7.2\end{array}$ & $\begin{array}{r}5.1 \\
4.7 \\
6.9 \\
-0.2 \\
8.3\end{array}$ & $\begin{array}{l}4.1 \\
4.8 \\
4.9 \\
3.0 \\
8.6\end{array}$ & $\begin{array}{r}3.4 \\
1.5 \\
3.3 \\
-4.6 \\
9.9\end{array}$ \\
\hline 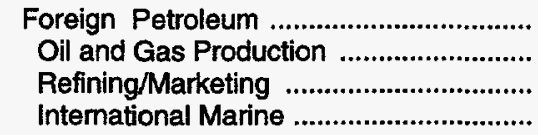 & $\begin{array}{r}11.2 \\
12.4 \\
10.5 \\
-0.1\end{array}$ & $\begin{array}{r}7.7 \\
9.9 \\
5.8 \\
-3.7\end{array}$ & $\begin{array}{r}9.1 \\
11.4 \\
6.7 \\
-0.9\end{array}$ & $\begin{array}{r}3.9 \\
2.6 \\
15.6 \\
18.3\end{array}$ & $\begin{array}{r}3.4 \\
2.4 \\
10.6 \\
181.3\end{array}$ & $\begin{array}{r}5.1 \\
4.8 \\
9.7 \\
-141.7\end{array}$ & $\begin{array}{r}6.6 \\
6.8 \\
4.6 \\
19.4\end{array}$ & $\begin{array}{r}1.6 \\
1.1 \\
5.5 \\
-6.5\end{array}$ & $\begin{array}{r}11.2 \\
10.1 \\
25.5 \\
-50.0\end{array}$ \\
\hline
\end{tabular}

Note: Profit rate measured as contribution to net income/net investment in place.

Source: Energy Information Administration, Form EIA-28. 
Table B8. A Comparison of Balance Sheet Items for FRS Companies and the S\&P 400, 1995 and Percent Change from 1994

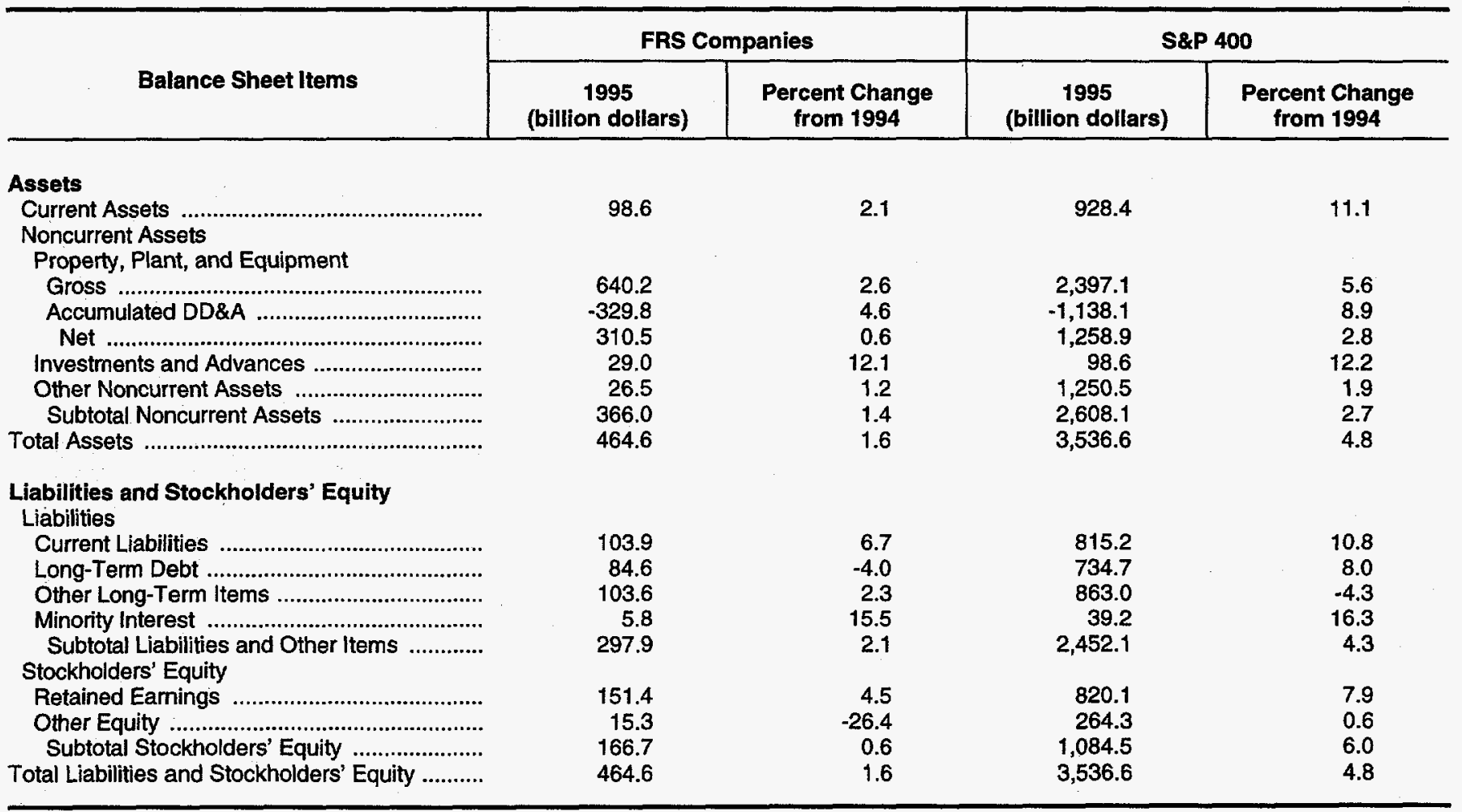

Sources: Standard \& Poor's (S\&P) 400 data - Compustat, Inc. FRS companies' data - Energy Information Administration, Form EIA-28. 
Table B9. Consolidated Balance Sheet for FRS Companies, 1989-1995

(Billion Dollars)

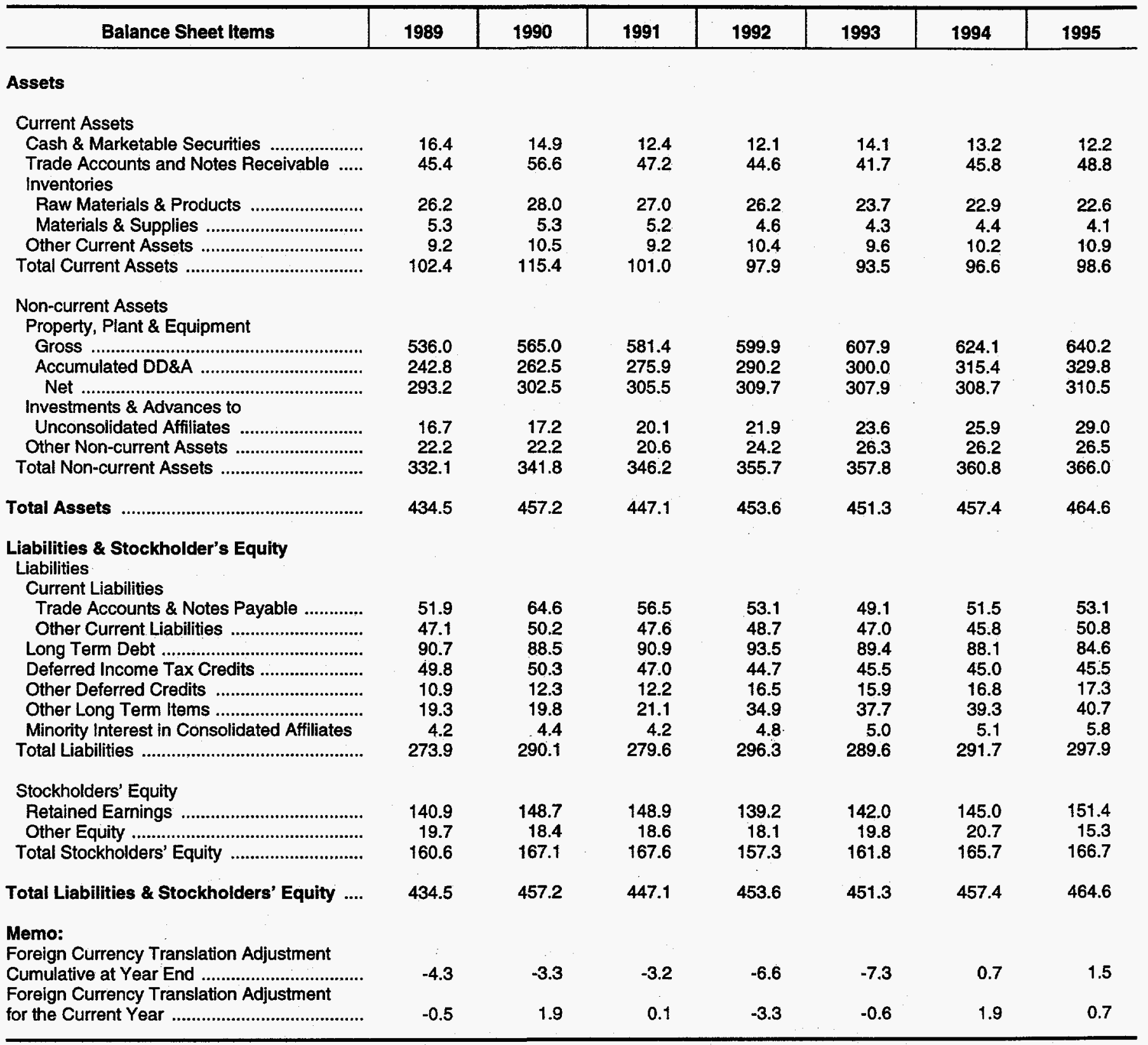

Source: Energy Information Administration, Form EIA-28. 
Table B10. Distribution of Net Investment in Place for FRS Companies, United States and Foreign, 1995

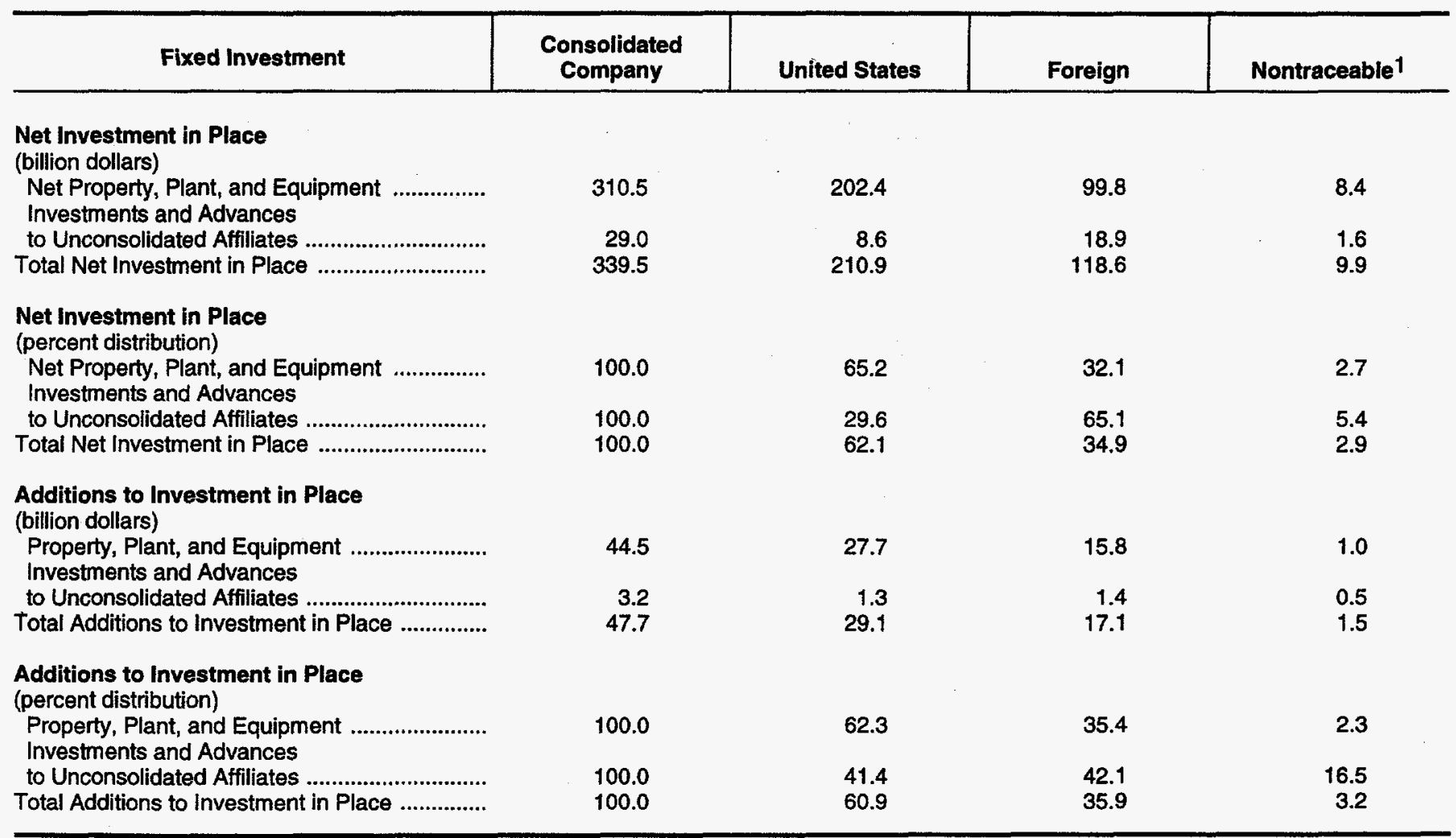

1 Includes items in consolidated balance sheet that cannot be allocated to segments (nontraceables). In this table, this column is derived as a residual.

Source: Energy Information Administration, Form EIA-28. 
Table B11. Net Property, Plant and Equipment (PP\&E), Additions to PP\&E, Investments and Advances, and Depreciation, Depletion and Amortization (DD\&A), by Lines of Business for FRS Companies, 1995 (Million Dollars)

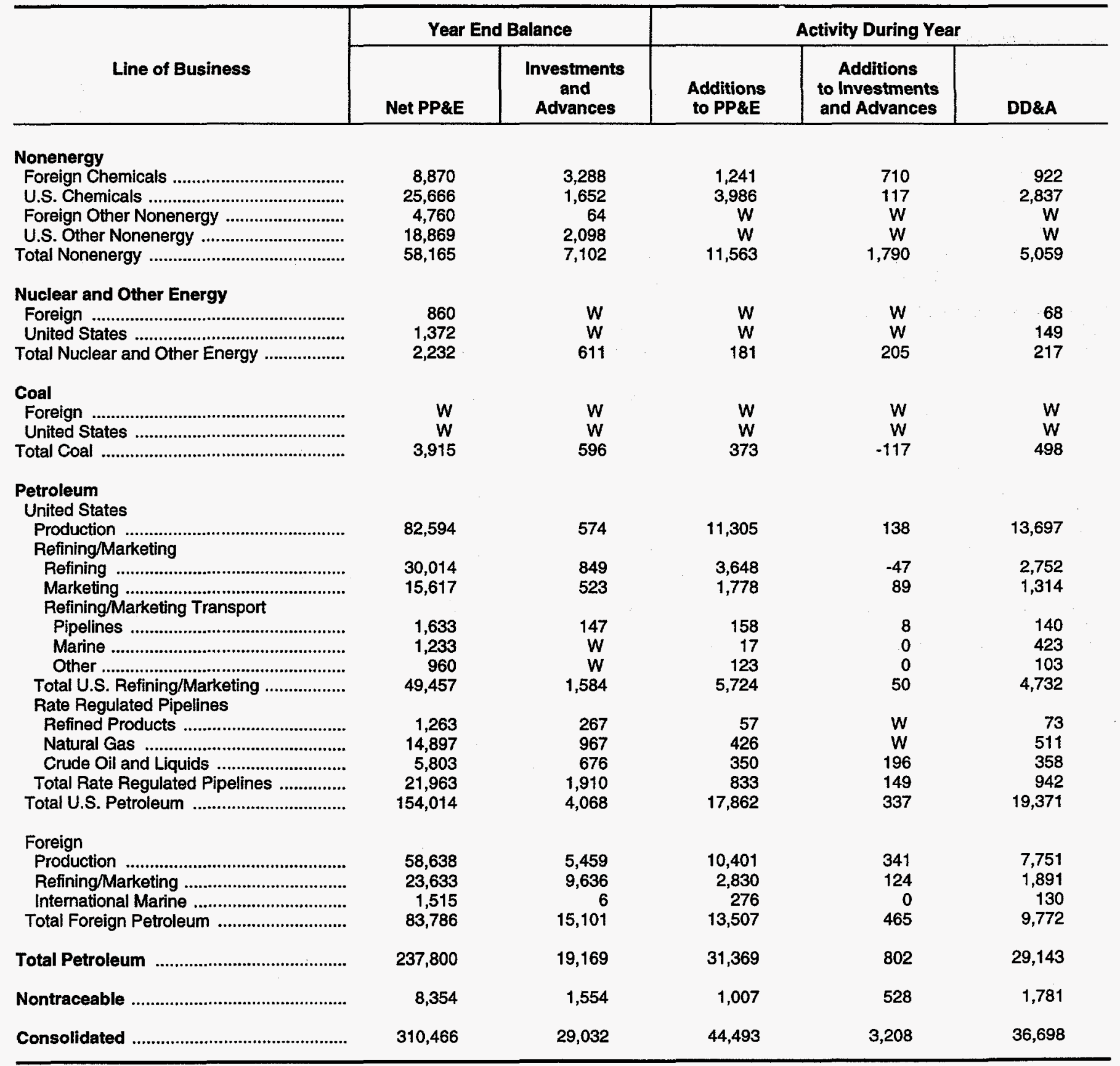

$W=$ Data withheld to avoid disclosure.

Source: Energy Information Administration, Form EIA-28. 
Table B12. Income and Investment Patterns in Worldwide Petroleum for FRS Companies Ranked by Total Energy Assets, 1995, and Percent Change from 1994

\begin{tabular}{|c|c|c|c|}
\hline Income and Investment & Worldwide & United States & Foreign \\
\hline & \multicolumn{3}{|c|}{ (million dollars) } \\
\hline \multicolumn{4}{|l|}{$\begin{array}{l}1995 \\
\text { Contribution to Net Income }\end{array}$} \\
\hline 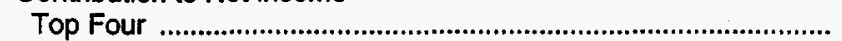 & $7,780.0$ & $1,495.0$ & $6,285.0$ \\
\hline 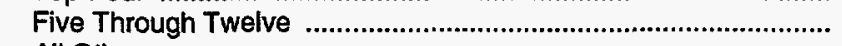 & $5,421.0$ & $4,363.0$ & $1,058.0$ \\
\hline 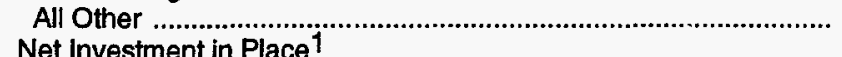 & $1,485.0$ & 515.0 & 970.0 \\
\hline $\begin{array}{l}\text { Net Investment in Place } \\
\text { Top Four }\end{array}$ & 117.958 .0 & $48,534.0$ & 69.4240 \\
\hline Five Through Twelve & $95,565.0$ & $74,768.0$ & $20,797.0$ \\
\hline All Other & $43,446.0$ & $34,780.0$ & $8,666.0$ \\
\hline \multicolumn{4}{|l|}{ Additions to Investment in Place } \\
\hline Top Four & $14,463.0$ & $5,135.0$ & $9,328.0$ \\
\hline Five Through Twelve & $11,109.0$ & $8,075.0$ & $3,034.0$ \\
\hline \multirow[t]{2}{*}{ All Other } & $6,599.0$ & $4,989.0$ & $1,610.0$ \\
\hline & \multicolumn{3}{|c|}{ (percent) } \\
\hline
\end{tabular}

Distribution, 1995

Contribution to Net Income

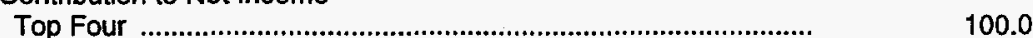

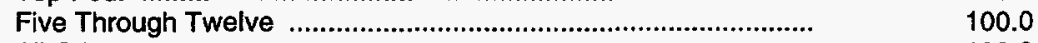

All Other .................................................................................

Net Investment in Place 1

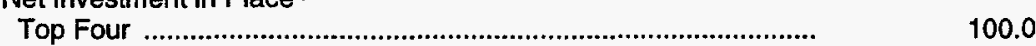

Five Through Twelve ..................................................................

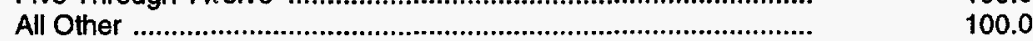

Additions to Investment in Place

Top Four

Five Through Twelve

100.0

All Other

Change from 1994

Contribution to Net Income

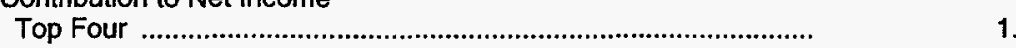

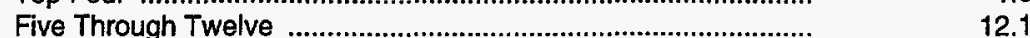

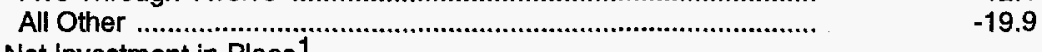

Net investment in Place ${ }^{1}$

Top Four

35.5

Five Through Twelve

All Other

$-4.0$

Top Four

All Other

1 Measured as net property, plant, and equipment plus investments and advances. Note: Sum of components may not equal total due to independent rounding, eliminations, and nontraceables. Source: Energy Information Administration, Form EIA-28. 
Table B13. Income and Investment Patterns by Petroleum Segments for FRS Companies Ranked by Total Energy Assets, 1995, and Percent Change from 1994

\begin{tabular}{|c|c|c|c|c|c|c|c|c|}
\hline \multirow[b]{2}{*}{ Income and Investment } & \multicolumn{4}{|c|}{ United States } & \multicolumn{4}{|c|}{ Foreign } \\
\hline & $\begin{array}{l}\text { Consoli- } \\
\text { dated }\end{array}$ & Production & $\begin{array}{l}\text { Refining/ } \\
\text { Marketing }\end{array}$ & Pipelines & $\begin{array}{l}\text { Consoli- } \\
\text { dated }\end{array}$ & Production & $\begin{array}{l}\text { Refining/ } \\
\text { Marketing }\end{array}$ & $\begin{array}{c}\text { Inter- } \\
\text { national } \\
\text { Marine }\end{array}$ \\
\hline & \multicolumn{8}{|c|}{ (million dollars) } \\
\hline \multicolumn{8}{|l|}{1995} & \\
\hline $\begin{array}{l}\text { Top Four .................................. } \\
\text { Five Through Twelve .................. } \\
\text { All Other ................................... } \\
\text { Net Investment in Place } 1\end{array}$ & $\begin{array}{r}1,495.0 \\
4,363.0 \\
515.0\end{array}$ & $\begin{array}{r}867.0 \\
2,258.0 \\
573.0\end{array}$ & $\begin{array}{r}146.0 \\
934.0 \\
-572.0\end{array}$ & $\begin{array}{r}482.0 \\
1,171.0 \\
514.0\end{array}$ & $\begin{array}{r}6,285.0 \\
1,058.0 \\
970.0\end{array}$ & $\begin{array}{r}4,223.0 \\
911.0 \\
808.0\end{array}$ & $\begin{array}{r}2,076.0 \\
164.0 \\
169.0\end{array}$ & $\begin{array}{r}-14.0 \\
-17.0 \\
-7.0\end{array}$ \\
\hline $\begin{array}{l}\text { Top Four ................................ } \\
\text { Five Through Twelve ................. } \\
\text { All Other .................................... } \\
\text { Additions to PP\&E2 }\end{array}$ & $\begin{array}{l}48,534.0 \\
74,768.0 \\
34,780.0\end{array}$ & $\begin{array}{l}26,794.0 \\
39,123.0 \\
17,251.0\end{array}$ & $\begin{array}{l}19,335.0 \\
19,361.0 \\
12,345.0\end{array}$ & $\begin{array}{r}2,405.0 \\
16,284.0 \\
5,184.0\end{array}$ & $\begin{array}{r}69,424.0 \\
20,797.0 \\
8,666.0\end{array}$ & $\begin{array}{r}37,014.0 \\
19,094.0 \\
7,989.0\end{array}$ & $\begin{array}{r}30,915.0 \\
1,691.0 \\
663.0\end{array}$ & $\begin{array}{r}1,495.0 \\
W \\
W\end{array}$ \\
\hline 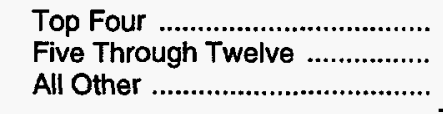 & $\begin{array}{l}5,079.0 \\
7,941.0 \\
4,842.0 \\
\end{array}$ & $\begin{array}{l}2,971.0 \\
5,074.0 \\
3,260.0\end{array}$ & $\begin{array}{l}1,975.0 \\
2,313.0 \\
1,436.0 \\
\end{array}$ & $\begin{array}{l}133.0 \\
554.0 \\
146.0 \\
\end{array}$ & $\begin{array}{l}8,874.0 \\
3,048.0 \\
1,585.0\end{array}$ & $\begin{array}{l}6,092.0 \\
2,791.0 \\
1,518.0 \\
\end{array}$ & $\begin{array}{r}2,508.0 \\
256.0 \\
66.0 \\
\end{array}$ & $\begin{array}{c}274.0 \\
W \\
W\end{array}$ \\
\hline 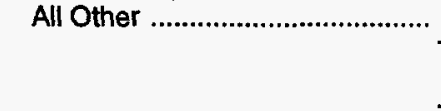 & \multicolumn{8}{|c|}{ (percent) } \\
\hline \multicolumn{9}{|l|}{$\begin{array}{l}\text { Distribution, } 1995 \\
\text { Contribution to Net Income }\end{array}$} \\
\hline $\begin{array}{l}\text { Top Four .................................. } \\
\text { Five Through Twelve ................. } \\
\text { All Other ................................. } \\
\text { Net Investment in Place } 1\end{array}$ & $\begin{array}{l}100.0 \\
100.0 \\
100.0\end{array}$ & $\begin{array}{r}58.0 \\
51.8 \\
111.3\end{array}$ & $\begin{array}{r}9.8 \\
21.4 \\
-111.1\end{array}$ & $\begin{array}{l}32.2 \\
26.8 \\
99.8\end{array}$ & $\begin{array}{l}100.0 \\
100.0 \\
100.0\end{array}$ & $\begin{array}{l}67.2 \\
86.1 \\
83.3\end{array}$ & $\begin{array}{l}33.0 \\
15.5 \\
17.4\end{array}$ & $\begin{array}{l}-0.2 \\
-1.6 \\
-0.7\end{array}$ \\
\hline $\begin{array}{l}\text { Top Four ................................ } \\
\text { Five Through Twelve ................. } \\
\text { All Other .................................... } \\
\text { Additions to PP\&E2 }\end{array}$ & $\begin{array}{l}100.0 \\
100.0 \\
100.0\end{array}$ & $\begin{array}{l}55.2 \\
52.3 \\
49.6\end{array}$ & $\begin{array}{l}39.8 \\
25.9 \\
35.5\end{array}$ & $\begin{array}{r}5.0 \\
21.8 \\
14.9\end{array}$ & $\begin{array}{l}100.0 \\
100.0 \\
100.0\end{array}$ & $\begin{array}{l}53.3 \\
91.8 \\
92.2\end{array}$ & $\begin{array}{r}44.5 \\
8.1 \\
7.7\end{array}$ & $\begin{array}{l}2.2 \\
W \\
W\end{array}$ \\
\hline $\begin{array}{l}\text { Top Four .................................... } \\
\text { Five Through Twelve ................. } \\
\text { All Other ................................... }\end{array}$ & $\begin{array}{l}100.0 \\
100.0 \\
100.0\end{array}$ & $\begin{array}{l}58.5 \\
63.9 \\
67.3\end{array}$ & $\begin{array}{l}38.9 \\
29.1 \\
29.7\end{array}$ & $\begin{array}{l}2.6 \\
7.0 \\
3.0\end{array}$ & $\begin{array}{l}100.0 \\
100.0 \\
100.0\end{array}$ & $\begin{array}{l}68.6 \\
91.6 \\
95.8\end{array}$ & $\begin{array}{r}28.3 \\
8.4 \\
4.2\end{array}$ & $\begin{array}{l}3.1 \\
W \\
W\end{array}$ \\
\hline \multicolumn{9}{|l|}{$\begin{array}{l}\text { Change from } 1994 \\
\text { Contribution to Net income }\end{array}$} \\
\hline $\begin{array}{l}\text { Top Four ................................. } \\
\text { Five Through Twelve ................. } \\
\text { All Other ................................. } \\
\text { Net Investment in Place }{ }^{1}\end{array}$ & $\begin{array}{r}-42.5 \\
5.0 \\
-69.8\end{array}$ & $\begin{array}{r}-51.0 \\
5.7 \\
-34.4\end{array}$ & $\begin{array}{l}-64.5 \\
-11.7 \\
(3)\end{array}$ & $\begin{array}{l}15.0 \\
21.9 \\
13.5\end{array}$ & $\begin{array}{r}23.1 \\
55.1 \\
542.4\end{array}$ & $\begin{array}{r}22.4 \\
111.9 \\
741.7\end{array}$ & $\begin{array}{r}20.9 \\
-26.5 \\
196.5\end{array}$ & 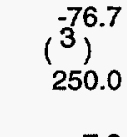 \\
\hline $\begin{array}{l}\text { Top Four ................................. } \\
\text { Five Through Tweive ................ } \\
\text { All Other .................................... } \\
\text { Additions to PP\&E2 }\end{array}$ & $\begin{array}{l}-6.2 \\
-1.7 \\
-2.9\end{array}$ & $\begin{array}{r}-10.1 \\
-2.0 \\
-3.6\end{array}$ & $\begin{array}{l}-0.7 \\
-1.9 \\
-2.4\end{array}$ & $\begin{array}{l}-1.9 \\
-0.4 \\
-1.9\end{array}$ & $\begin{array}{r}5.0 \\
2.7 \\
-8.2\end{array}$ & $\begin{array}{r}5.9 \\
5.3 \\
-4.6\end{array}$ & $\begin{array}{r}4.8 \\
-19.6 \\
-35.9\end{array}$ & $\begin{array}{l}-7.9 \\
W \\
W\end{array}$ \\
\hline $\begin{array}{l}\text { Top Four .................................. } \\
\text { Five Through Twelve .................. } \\
\text { All Other .................................... }\end{array}$ & $\begin{array}{r}5.4 \\
10.1 \\
-17.0\end{array}$ & $\begin{array}{r}16.1 \\
19.0 \\
-19.8\end{array}$ & $\begin{array}{r}-9.3 \\
-10.5 \\
-7.8\end{array}$ & $\begin{array}{r}58.3 \\
51.4 \\
-31.1\end{array}$ & $\begin{array}{l}19.4 \\
-7.9 \\
12.1\end{array}$ & $\begin{array}{l}29.6 \\
-7.7 \\
14.7\end{array}$ & $\begin{array}{r}1.2 \\
-10.2 \\
-25.8\end{array}$ & $\begin{array}{l}9.6 \\
W \\
W\end{array}$ \\
\hline
\end{tabular}

1 Measured as net property, plant, and equipment plus investments and advances.

2 Property, plant, and equipment.

3 Not meaningful.

W = Data withheld to avoid disclosure.

Note: Sum of components may not equal total due to independent rounding, eliminations, and nontraceables.

Source: Energy Information Administration, Form EIA-28. 
Table B14. Size Distribution of Income and Investment Within Worldwide Petroleum for FRS Companies Ranked by Total Energy Assets, 1993-1995

(Percent)

\begin{tabular}{|c|c|c|c|c|c|c|c|c|c|}
\hline $\begin{array}{l}\text { Patterns Across } \\
\text { Size Groups }\end{array}$ & 1993 & 1994 & 1995 & 1993 & 1994 & 1995 & 1993 & 1994 & 1995 \\
\hline 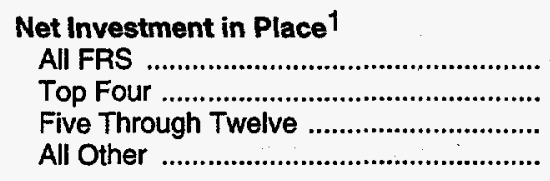 & $\begin{array}{r}100.0 \\
44.8 \\
37.6 \\
17.6\end{array}$ & $\begin{array}{r}100.0 \\
45.4 \\
37.1 \\
17.5\end{array}$ & $\begin{array}{r}100.0 \\
45.9 \\
37.2 \\
16.9\end{array}$ & $\begin{array}{r}100.0 \\
32.3 \\
46.5 \\
21.3\end{array}$ & $\begin{array}{r}100.0 \\
31.6 \\
46.5 \\
21.9\end{array}$ & $\begin{array}{r}100.0 \\
30.7 \\
47.3 \\
22.0\end{array}$ & $\begin{array}{r}100.0 \\
67.6 \\
21.6 \\
10.8\end{array}$ & $\begin{array}{r}100.0 \\
69.0 \\
21.1 \\
9.9\end{array}$ & $\begin{array}{r}100.0 \\
70.2 \\
21.0 \\
8.8\end{array}$ \\
\hline 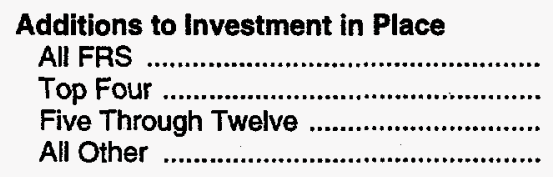 & $\begin{array}{r}100.0 \\
43.3 \\
36.4 \\
20.3\end{array}$ & $\begin{array}{r}100.0 \\
41.6 \\
34.9 \\
23.5\end{array}$ & $\begin{array}{r}100.0 \\
45.0 \\
34.5 \\
20.5\end{array}$ & $\begin{array}{r}100.0 \\
30.2 \\
41.5 \\
28.3\end{array}$ & $\begin{array}{r}100.0 \\
26.7 \\
40.5 \\
32.7\end{array}$ & $\begin{array}{r}100.0 \\
28.2 \\
44.4 \\
27.4\end{array}$ & $\begin{array}{r}100.0 \\
55.6 \\
31.4 \\
11.2\end{array}$ & $\begin{array}{r}100.0 \\
62.1 \\
27.1 \\
10.8\end{array}$ & $\begin{array}{r}100.0 \\
66.8 \\
21.7 \\
11.5\end{array}$ \\
\hline
\end{tabular}

1. Measured as net property, plant, and equipment plus investments and advances.

Source: Energy Information Administration, Form EIA-28. 
Table B15. Consolidated Statement of Cash Flows for FRS Companies, 1989-1995

(Million Dollars)

\begin{tabular}{|c|c|c|c|c|c|c|c|}
\hline Cash Flows 1 & 1989 & 1990 & 1991 & 1992 & 1993 & 1994 & 1995 \\
\hline \multicolumn{8}{|l|}{ Cash Flows From Operations } \\
\hline Net Income & 19,784 & 21,608 & 14,679 & 1,757 & 15,488 & 16,547 & 21,131 \\
\hline $\begin{array}{l}\text { Minority Interest in Income } \\
\text { Noncash ftems }\end{array}$ & 424 & 408 & 235 & 344 & 397 & 513 & 731 \\
\hline DD\&A ................. & 29,598 & 30,739 & 30,017 & 31,033 & 30,355 & 30,667 & 36,698 \\
\hline 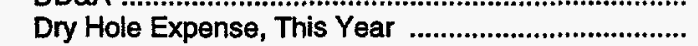 & 2,258 & 2,796 & 2,841 & 1,986 & 1,673 & 1,805 & 1,510 \\
\hline 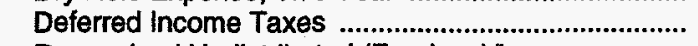 & 189 & -39 & $-2,062$ & $-3,929$ & -990 & 509 & -327 \\
\hline \multicolumn{8}{|l|}{ Recognized Undistributed (Earnings)/Losses } \\
\hline 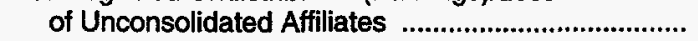 & -794 & -777 & -829 & -350 & -137 & -372 & -845 \\
\hline (Gain)/Loss on Disposition of PP\&E ............................. & $-3,335$ & -795 & $-1,808$ & $-1,294$ & -941 & -570 & $-2,471$ \\
\hline \multicolumn{8}{|l|}{ Changes in Operating Assets and Liabilities } \\
\hline Other Cash Items, Net & $\begin{array}{r}809 \\
-649\end{array}$ & $\begin{array}{r}2,883 \\
-1,930\end{array}$ & $\begin{array}{l}2,144 \\
2,002\end{array}$ & $\begin{array}{r}15,442 \\
-231\end{array}$ & $\begin{array}{l}2,191 \\
1.560\end{array}$ & $\begin{array}{r}527 \\
-1327\end{array}$ & 2,483 \\
\hline 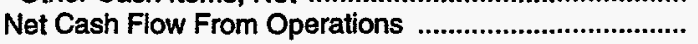 & 48,284 & 54,893 & 47,819 & 44,758 & 50,196 & $\begin{array}{l}-1,0<7 \\
48,299\end{array}$ & 58,498 \\
\hline \multicolumn{8}{|l|}{$\begin{array}{l}\text { Cash Flows From Investing Activities } \\
\text { Additions to PP\&E: }\end{array}$} \\
\hline 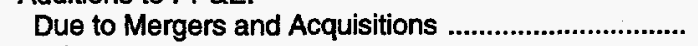 & $-8,676$ & $-3,467$ & $-1,075$ & -874 & -306 & $-2,271$ & $-4,137$ \\
\hline Other & $-34,847$ & $-41,122$ & $-43,812$ & $-39,604$ & $-37,755$ & $-35,217$ & $-40,356$ \\
\hline Total Additions to PP\&E & $-43,523$ & $-44,589$ & $-44,887$ & $-40,478$ & $-38,061$ & $-37,488$ & $-44,493$ \\
\hline 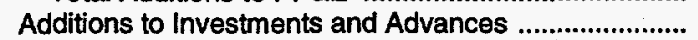 & $-1,468$ & -886 & $-1,520$ & $-1,483$ & $-2,318$ & $-1,588$ & $-3,208$ \\
\hline 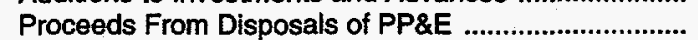 & 13,404 & 7,143 & 9,359 & 7,268 & 11,757 & 6,447 & 9,063 \\
\hline 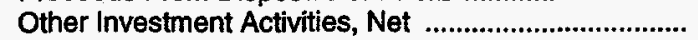 & $-2,209$ & 327 & -103 & $-1,584$ & $-2,242$ & $-2,363$ & 4,086 \\
\hline 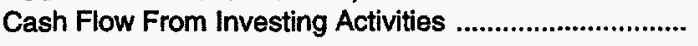 & $-33,796$ & $-38,005$ & $-37,151$ & $-36,277$ & $-30,864$ & $-34,992$ & $-34,552$ \\
\hline \multicolumn{8}{|l|}{ Cash Flows From Financing Activities } \\
\hline 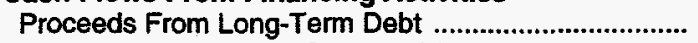 & 20,668 & 15,759 & 22,120 & 24,745 & 18,982 & 12,500 & 19,929 \\
\hline Proceeds From Equity Security Offerings ..................... & 4,248 & 1,501 & 491 & 3,438 & 2,146 & 2,614 & 3,471 \\
\hline 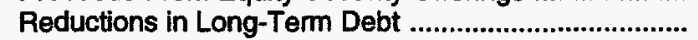 & $-19,820$ & $-17,223$ & $-18,411$ & $-25,284$ & $-20,886$ & $-13,760$ & $-18,657$ \\
\hline Purchase of Treasury Stock & $-6,190$ & $-5,435$ & $-1,973$ & -824 & -514 & $-1,010$ & $-10,035$ \\
\hline 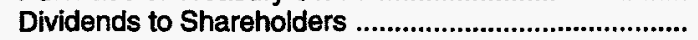 & $-16,699$ & $-13,300$ & $-13,497$ & $-13,521$ & $-13,563$ & $-14,906$ & $-15,238$ \\
\hline \multicolumn{8}{|c|}{ Other Financing Activities, Including Net Change } \\
\hline 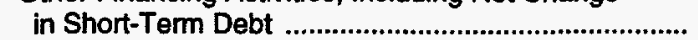 & 2,111 & 243 & -978 & 2,308 & $-4,102$ & $-1,091$ & $-2,350$ \\
\hline Cash Flow From Financing Activities .................................... & $-15,682$ & $-18,455$ & $-12,248$ & $-9,138$ & $-17,937$ & $-15,653$ & $-22,880$ \\
\hline Effect of Exchange Rate on Cash & -286 & 74 & -138 & -359 & -198 & 131 & 14 \\
\hline \multicolumn{8}{|l|}{ Net Increase/(Decrease) in Cash and Cash } \\
\hline 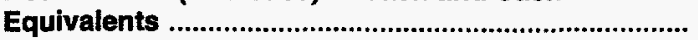 & $-1,480$ & $-1,493$ & $-1,718$ & $-1,016$ & 1,197 & $-2,215$ & 1,080 \\
\hline
\end{tabular}

1 Items that add to cash are positive, and items that use cash are shown as negative values.

Source: Energy Information Administration, Form EIA-28. 
Table B16. A Comparison of Key Financial Indicators, Selected Performance Measures, and Patterns of Finance for FRS Companies and for the S\&P 400, 1993-1995

(Percent)

\begin{tabular}{|c|c|c|c|c|c|c|}
\hline \multirow{2}{*}{ Financial Indicators } & \multicolumn{3}{|c|}{ FRS Companies } & \multicolumn{3}{|c|}{ S\&P 400} \\
\hline & 1993 & 1994 & 1995 & 1993 & 1994 & 1995 \\
\hline \multicolumn{7}{|l|}{ Profitability Measures } \\
\hline Net Income to Total Assets & 3.4 & 3.6 & 4.5 & 2.6 & 4.9 & 4.8 \\
\hline 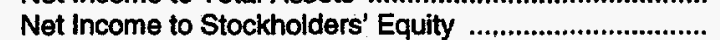 & 9.6 & 10.0 & 12.7 & 9.4 & 16.1 & 15.7 \\
\hline Net Income Plus Interest to Total Invested Capital ......... & 9.3 & 9.7 & 11.7 & 10.3 & 13.5 & 13.4 \\
\hline \multicolumn{7}{|l|}{ Cash Flow from Operations and Uses of Cash } \\
\hline Net Cash Flow from Operations to Total Assets ............. & 11.1 & 10.6 & 12.6 & 8.9 & 9.7 & 10.4 \\
\hline Additions to PP\&E to Net Cash Flow from Operations ... & 75.8 & 77.6 & 76.1 & 63.3 & 66.0 & 66.2 \\
\hline Dividends to Net Cash Flow from Operations ..................... & 27.0 & 30.9 & 26.0 & 22.7 & 22.0 & 20.7 \\
\hline \multicolumn{7}{|l|}{ Liquidity and Leverage Measures } \\
\hline Long-Term Debt to Stockholders' Equity .......................... & 55.2 & 53.1 & 50.7 & 69.1 & 66.5 & 67.7 \\
\hline 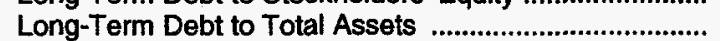 & 19.8 & 19.3 & 18.2 & 19.1 & 20.2 & 20.8 \\
\hline 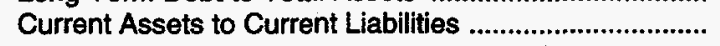 & 97.3 & 99.2 & 94.9 & 100.4 & 113.6 & 113.9 \\
\hline
\end{tabular}

Sources: Standard \& Poor's (S\&P) 400 data - Compustat, Inc. FRS companies' data - Energy Information Administration, Form ElA-28. 
Table B17. Worldwide Income Taxes for FRS Companies, 1994 and 1995

\begin{tabular}{|c|c|c|c|c|c|}
\hline \multirow{2}{*}{$\begin{array}{c}\text { Taxes by } \\
\text { Geographic Sector }\end{array}$} & \multicolumn{2}{|c|}{ Billion Dollars } & \multirow{2}{*}{$\begin{array}{c}\text { Percent Change } \\
\text { from } 1994\end{array}$} & \multicolumn{2}{|c|}{$\begin{array}{l}\text { Income Taxes as a } \\
\text { Percent of Pretax Income }\end{array}$} \\
\hline & 1994 & 1995 & & 1994 & 1995 \\
\hline 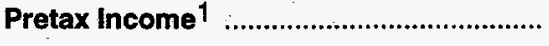 & 29.6 & 34.2 & 15.7 & 100.0 & 100.0 \\
\hline 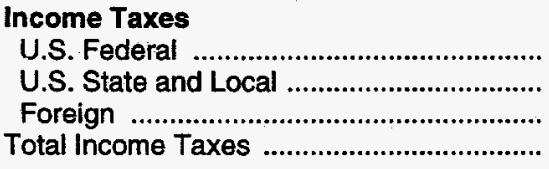 & $\begin{array}{r}2.6 \\
0.5 \\
7.6 \\
10.6\end{array}$ & $\begin{array}{r}3.6 \\
0.6 \\
8.5 \\
12.8\end{array}$ & $\begin{array}{l}37.7 \\
31.1 \\
13.1 \\
19.9\end{array}$ & $\begin{array}{r}8.8 \\
1.6 \\
25.5 \\
35.9\end{array}$ & $\begin{array}{r}10.5 \\
1.8 \\
25.0 \\
37.2\end{array}$ \\
\hline 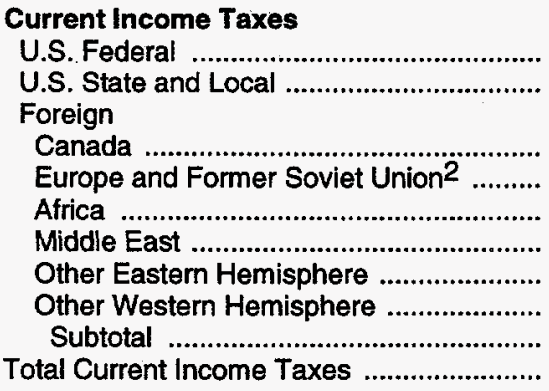 & $\begin{array}{r}0.7 \\
2.3 \\
1.1 \\
0.8 \\
2.1 \\
0.5 \\
7.5 \\
10.0\end{array}$ & $\begin{array}{r}0.6 \\
2.8 \\
1.2 \\
1.0 \\
1.9 \\
0.5 \\
8.0 \\
13.1\end{array}$ & $\begin{array}{r}-10.1 \\
19.7 \\
6.8 \\
22.6 \\
-9.7 \\
10.8 \\
6.6 \\
31.6\end{array}$ & $\begin{array}{r}2.4 \\
7.8 \\
3.8 \\
2.8 \\
7.0 \\
1.6 \\
25.4 \\
33.7\end{array}$ & $\begin{array}{r}13.1 \\
1.9 \\
1.9 \\
8.0 \\
3.5 \\
3.0 \\
5.5 \\
1.5 \\
23.4 \\
38.4\end{array}$ \\
\hline 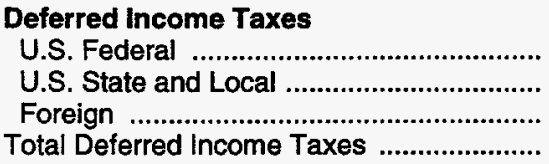 & $\begin{array}{r}0.7 \\
-0.1 \\
0.0 \\
0.7\end{array}$ & $\begin{array}{r}-0.9 \\
0.0 \\
0.5 \\
-0.4\end{array}$ & $\begin{array}{l}\left(\begin{array}{l}3 \\
3\end{array}\right) \\
\left(\begin{array}{l}3 \\
3\end{array}\right)\end{array}$ & $\begin{array}{r}2.3 \\
-0.2 \\
0.1 \\
2.2\end{array}$ & $\begin{array}{r}-2.6 \\
-0.1 \\
1.6 \\
-1.1\end{array}$ \\
\hline
\end{tabular}

1 Excludes discontinued operations, extraordinary items, and cumulative effect of accounting changes.

2 OECD Europe combined with the former Soviet Union and Eastern Europe to avoid disclosure. Prior to 1993, only OECD Europe is included in this region.

3 Not meaningful.

Source: Energy Information Administration, Form ElA-28. 
Table B18. U.S. Federal Income Taxes for FRS Companies, 1994 and 1995

\begin{tabular}{|c|c|c|c|c|c|}
\hline \multirow{2}{*}{ U.S. Tax Determination } & \multicolumn{2}{|c|}{ Billion Dollars } & \multirow{2}{*}{$\begin{array}{l}\text { Percent Change } \\
\text { from } 1994\end{array}$} & \multicolumn{2}{|c|}{$\begin{array}{l}\text { Percent of Net Income } \\
\text { Before Taxes }\end{array}$} \\
\hline & 1994 & 1995 & & 1994 & 1995 \\
\hline $\begin{array}{l}\text { Pretax Income } \\
\text { (worldwide) }\end{array}$ & 29.6 & 34.2 & 15.7 & 100.0 & 100.0 \\
\hline $\begin{array}{l}\text { Adjustments to Income } \\
\text { Income Not Subject to U.S. Taxes ........... } \\
\text { Deductions for Income } \\
\text { Taxes Paid in Other Jurisdictions ............. }\end{array}$ & $\begin{array}{l}-3.6 \\
-0.8\end{array}$ & $\begin{array}{l}-4.0 \\
-0.8\end{array}$ & $\begin{array}{r}13.0 \\
6.8\end{array}$ & $\begin{array}{r}-12.1 \\
-2.6\end{array}$ & $\begin{array}{r}-11.8 \\
-2.4\end{array}$ \\
\hline 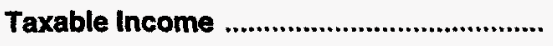 & 25.3 & 29.4 & 16.3 & 85.3 & 85.8 \\
\hline 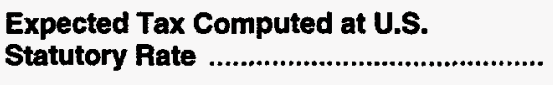 & 8.8 & 10.3 & 16.3 & 29.9 & 30.0 \\
\hline 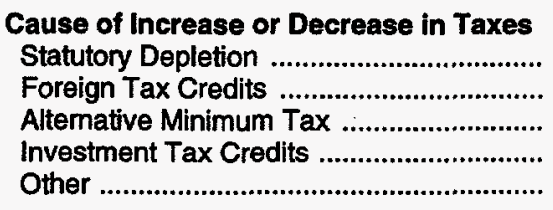 & $\begin{array}{r}-0.1 \\
-4.8 \\
0.0 \\
0.0 \\
-1.3\end{array}$ & $\begin{array}{r}-0.1 \\
-5.7 \\
0.0 \\
-0.1 \\
-0.9\end{array}$ & $\begin{array}{l}34.6 \\
17.2 \\
0.0 \\
\left(\begin{array}{c}2 \\
0\end{array}\right) \\
-33.9\end{array}$ & $\begin{array}{r}-0.2 \\
-16.3 \\
0.0 \\
-0.1 \\
-4.4\end{array}$ & $\begin{array}{r}-0.2 \\
-16.5 \\
0.0 \\
-0.3 \\
-2.5\end{array}$ \\
\hline 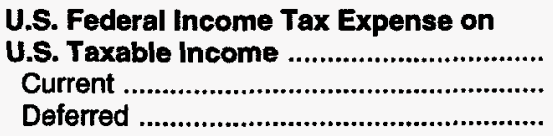 & $\begin{array}{l}2.6 \\
1.9 \\
0.7\end{array}$ & $\begin{array}{r}3.6 \\
4.5 \\
-0.9\end{array}$ & $\begin{array}{r}38.0 \\
131.0 \\
(2)\end{array}$ & $\begin{array}{l}8.8 \\
6.5 \\
2.3\end{array}$ & $\begin{array}{l}10.5 \\
13.1 \\
-2.6\end{array}$ \\
\hline
\end{tabular}

1 Excludes discontinued operations, extraordinary items, and cumulative effect of accounting changes.

2 Not meaningful.

Source: Energy Information Administration, Form EIA-28. 
Table B19. Analysis of Income Taxes for FRS Companies, 1989-1995

(Million Dollars)

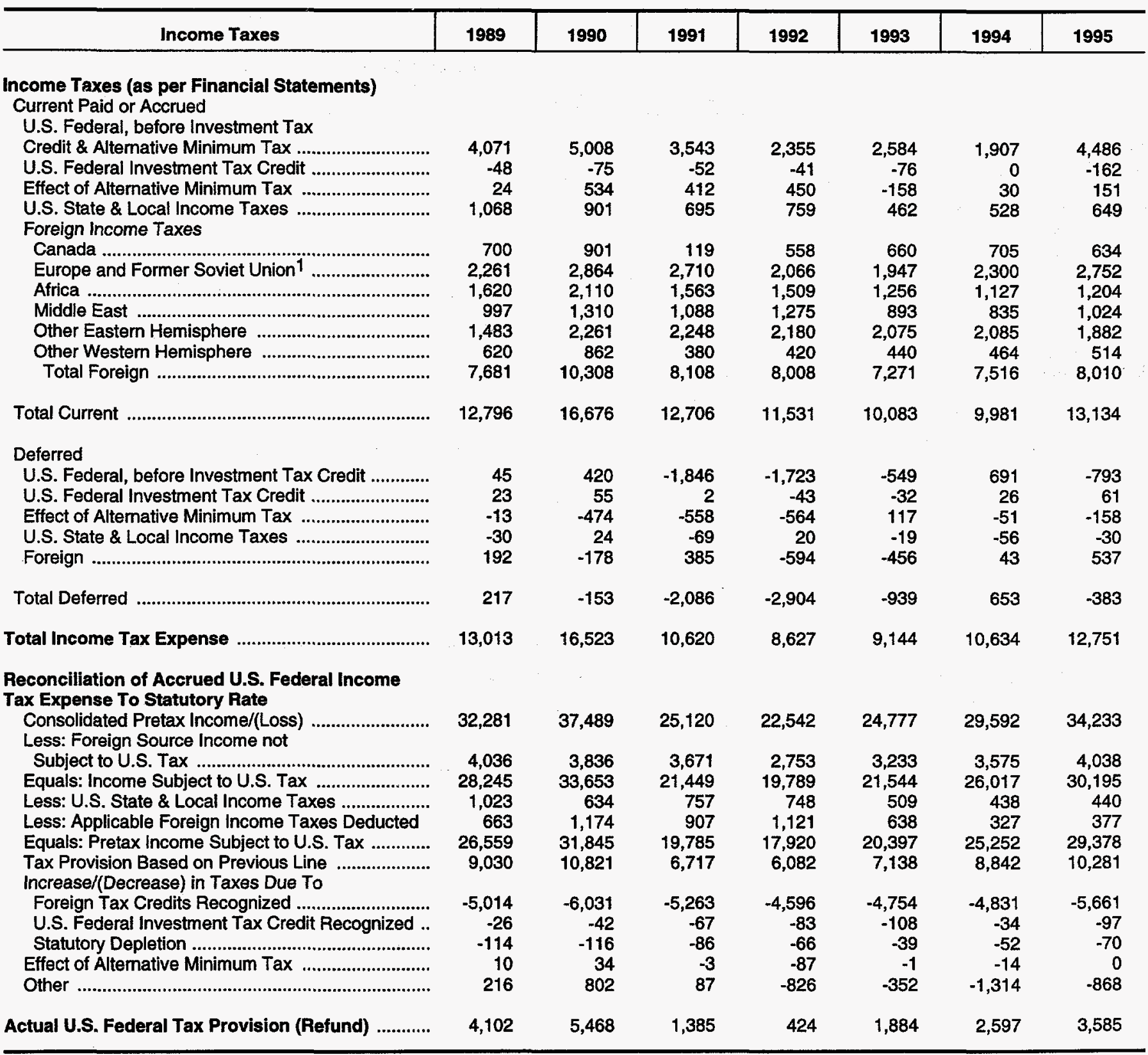

1 OECD Europe combined with the former Soviet Union and Eastern Europe to avoid disclosure. Prior to 1993, only OECD Europe is included in this region.

Source: Energy Information Administration, Form EIA-28. 
Table B20. U.S. Taxes Other Than Income Taxes for FRS Companies, 1995, and Percent Change from 1994

\begin{tabular}{|c|c|c|c|c|c|c|c|c|}
\hline \multirow[b]{2}{*}{$\begin{array}{l}\text { U.S. Taxes Other } \\
\text { than Income Taxes }\end{array}$} & \multicolumn{2}{|c|}{ Total United States } & \multicolumn{2}{|c|}{ Petroleum } & \multicolumn{2}{|c|}{ Coal } & \multicolumn{2}{|c|}{ Other 1} \\
\hline & $\begin{array}{c}1995 \\
\text { (million } \\
\text { dollars) }\end{array}$ & $\begin{array}{c}\text { Percent } \\
\text { Change } \\
\text { from 1994 }\end{array}$ & $\begin{array}{c}1995 \\
\text { (million } \\
\text { dollars) }\end{array}$ & $\begin{array}{c}\text { Percent } \\
\text { Change } \\
\text { from 1994 }\end{array}$ & $\begin{array}{c}1995 \\
\text { (million } \\
\text { dollars) }\end{array}$ & $\begin{array}{c}\text { Percent } \\
\text { Change } \\
\text { from 1994 }\end{array}$ & $\begin{array}{l}1995 \\
\text { (million } \\
\text { dollars) }\end{array}$ & $\begin{array}{c}\text { Percent } \\
\text { Change } \\
\text { from } 1994\end{array}$ \\
\hline 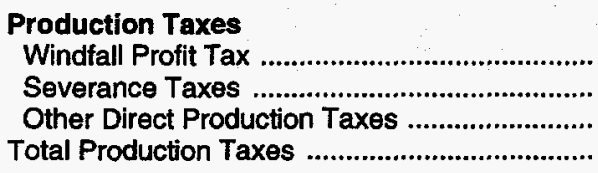 & $\begin{array}{r}0.0 \\
1,596.0 \\
265.0 \\
1,861.0\end{array}$ & $\begin{array}{r}0.0 \\
-4.9 \\
54.1 \\
0.6\end{array}$ & $\begin{array}{r}0.0 \\
1,531.0 \\
162.0 \\
1,693.0\end{array}$ & $\begin{array}{r}0.0 \\
-5.4 \\
62.0 \\
-1.5\end{array}$ & $\begin{array}{r}0.0 \\
57.0 \\
100.0 \\
157.0\end{array}$ & $\begin{array}{c}W \\
W \\
24.6\end{array}$ & $\begin{array}{l}0.0 \\
W \\
W \\
11.0\end{array}$ & $\begin{array}{c}W \\
W \\
120.0\end{array}$ \\
\hline 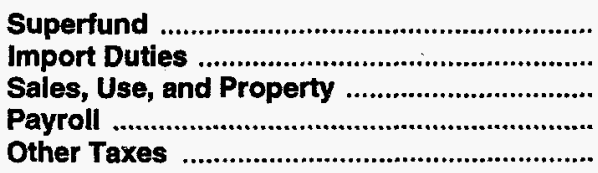 & $\begin{array}{r}293.0 \\
104.0 \\
2,886.0 \\
1,844.0 \\
566.0\end{array}$ & $\begin{array}{r}0.7 \\
-14.8 \\
-6.6 \\
-7.2 \\
-10.2\end{array}$ & $\begin{array}{c}225.0 \\
- \\
- \\
- \\
-\end{array}$ & $\begin{array}{l}-9.6 \\
- \\
- \\
-\end{array}$ & $\begin{array}{l}0.0 \\
- \\
- \\
- \\
-\end{array}$ & $\begin{array}{l}- \\
- \\
- \\
-\end{array}$ & $\begin{array}{c}68.0 \\
- \\
- \\
- \\
-\end{array}$ & $\begin{array}{c}61.9 \\
- \\
- \\
- \\
-\end{array}$ \\
\hline $\begin{array}{l}\text { Total Taxes Paid (Other Than Income } \\
\text { Taxes) } \ldots . . . \ldots \ldots \ldots \ldots \ldots \ldots \ldots \ldots \ldots \ldots \ldots \ldots \ldots \ldots \ldots \ldots \ldots \ldots \ldots \ldots \ldots \ldots \ldots\end{array}$ & $7,554.0$ & -5.2 & - & - & - & - & - & - \\
\hline 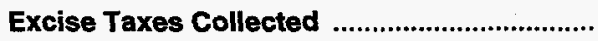 & $30,813.0$ & 2.4 & - & - & - & - & - & - \\
\hline
\end{tabular}

1 Nuclear, Other Energy, and Nonenergy.

$\bar{w}=$ Not available.

$W=$ Data withheld to avoid disclosure.

- = Not applicable.

Source: Energy Information Administration, Form EIA-28. 
Table B21. Petroleum Exploration and Development Expenditures for FRS Companies, United States and Foreign, 1995, and Percent Change from 1994

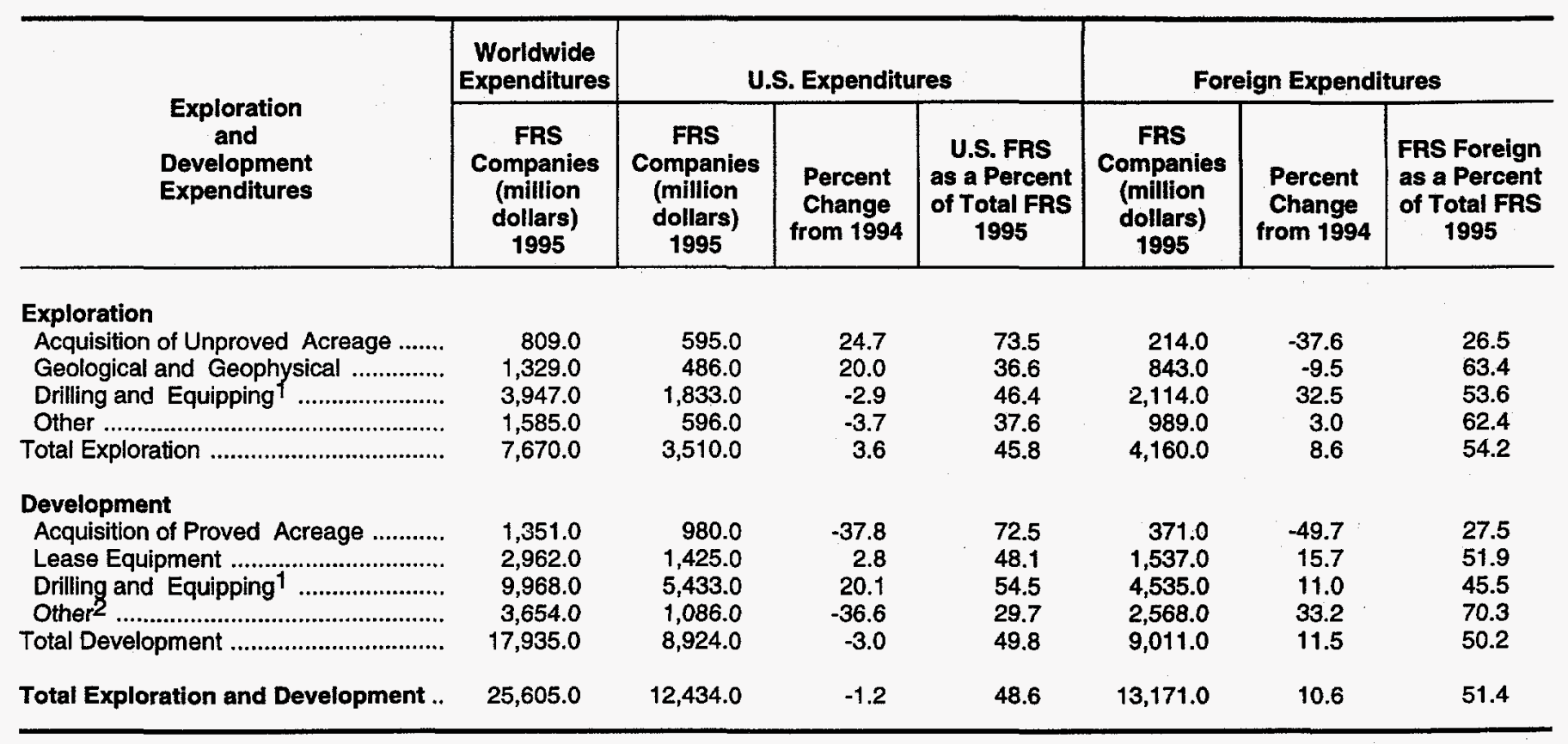

1 Expenditure incurred in a given year not cumulative (includes work in progress adjustment).

2 includes support equipment.

Source: Energy Information Administration, Form EIA-28. 
Table B22. U.S. and Foreign Exploration and Development Expenditures and Production (Lifting) Costs for FRS Companies, 1995

(Million Dollars)

\begin{tabular}{|c|c|c|c|c|c|}
\hline \multirow{2}{*}{ Expenditures } & \multirow{2}{*}{ Worldwide } & \multicolumn{3}{|c|}{ United States } & \multirow{2}{*}{ Foreig } \\
\hline & & Total & Onshore & Offshore & \\
\hline \multicolumn{6}{|l|}{$\begin{array}{l}\text { Exploration and Development } \\
\text { Expenditures }\end{array}$} \\
\hline \multicolumn{6}{|l|}{ Exploration Expenditures } \\
\hline $\begin{array}{l}\text { Unproved Acreage ........................................... } \\
\text { Drilling and Equipping }\end{array}$ & 809 & 595 & 332 & 263 & 214 \\
\hline 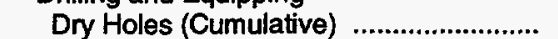 & - & 675 & 307 & 368 & _- \\
\hline 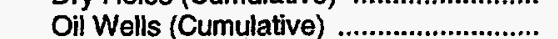 & - & 236 & 77 & 159 & _ \\
\hline 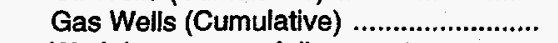 & - & 447 & 194 & 253 & - \\
\hline Work-in-progress Adjustment ..................... & - & 475 & 154 & 321 & _- \\
\hline Total Drilling and Equipping .......................... & 3,947 & 1,833 & 732 & 1,101 & 2,114 \\
\hline 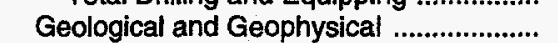 & 1,329 & 486 & 243 & 243 & 843 \\
\hline Other, Including Direct Overhead ............ & 1,585 & 596 & 337 & 259 & 989 \\
\hline Total Exploration Expenditures .................... & 7,670 & 3,510 & 1,644 & 1,866 & 4,160 \\
\hline \multicolumn{6}{|l|}{ Development Expenditures } \\
\hline Proved Acreage & & & & & \\
\hline $\begin{array}{l}\text { (Including Mergers and Acquisitions) ..... } \\
\text { Drilling and Equipping }\end{array}$ & 1,351 & 980 & 813 & 167 & 371 \\
\hline $\begin{array}{l}\text { Dniling and Equipping } \\
\text { Dry Holes (Cumulative) ............................ }\end{array}$ & _ & 197 & 118 & 79 & - \\
\hline Oil Wells (Cumulative) ………........................... & - & 1,643 & 1,063 & 580 & - \\
\hline 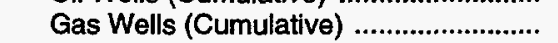 & - & 1,703 & 1,332 & 371 & - \\
\hline 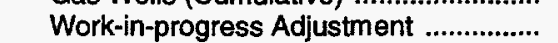 & - & 1,890 & 888 & 1,002 & - \\
\hline Total Drilling and Equipping ................... & 9,968 & 5,433 & 3,401 & 2,032 & 4,535 \\
\hline Lease Equipment .................................... & 2,962 & 1,425 & 941 & 484 & 1,537 \\
\hline $\begin{array}{l}\text { Other Development } \\
\text { Support Equipment }\end{array}$ & & & & & \\
\hline $\begin{array}{l}\text { Support Equipment ................................... } \\
\text { Other. Including Direct Overhead }\end{array}$ & $\begin{array}{r}389 \\
3265\end{array}$ & 140 & 117 & 23 & $\begin{array}{r}249 \\
2319\end{array}$ \\
\hline $\begin{array}{l}\text { Other, Including Direct Overhead .......... } \\
\text { Total Development Expenditures ............ }\end{array}$ & $\begin{array}{r}3,265 \\
17,935\end{array}$ & $\begin{array}{r}946 \\
8,924\end{array}$ & 6,051 & $\begin{array}{r}167 \\
2.873\end{array}$ & $\begin{array}{l}2,319 \\
9,011\end{array}$ \\
\hline \multicolumn{6}{|l|}{ Total Exploration and Development } \\
\hline 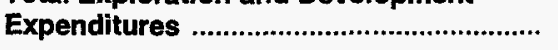 & 25,605 & 12,434 & 7,695 & 4,739 & 13,171 \\
\hline \multicolumn{6}{|l|}{ Production (Lifting) Costs } \\
\hline Windfall Profit Tax ................. & 0 & 0 & - & - & 0 \\
\hline Other Severance and Production Taxes .. & 2,563 & 1,693 & - & - & 870 \\
\hline Other Production Expenses .............................. & 18,681 & 10,439 & - & - & 8,242 \\
\hline Total Production (Lifting) Costs ............... & 21,244 & 12,132 & 9,775 & 2,357 & 9,112 \\
\hline Total Expenditures and Costs Incurred & 46,849 & 24,566 & 17,470 & 7,096 & 22,283 \\
\hline
\end{tabular}

- Not available.

Source: Energy Information Administration, Form EIA-28. 
Table B23. Total Exploratory and Development Wells Drilled in the United States for FRS Companies and U.S. Industry, 1994 and 1995

\begin{tabular}{|c|c|c|c|c|c|c|}
\hline \multirow{2}{*}{ Wells Drilled } & \multicolumn{2}{|c|}{ U.S. Industry } & \multicolumn{2}{|c|}{ FRS } & \multicolumn{2}{|c|}{ All Other } \\
\hline & 1994 & 1995 & 1994 & 1995 & 1994 & 1995 \\
\hline \multicolumn{7}{|l|}{ Exploratory } \\
\hline 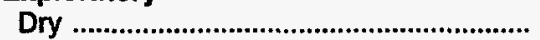 & 2,285 & 1,952 & 253 & 304 & 2,032 & 1,648 \\
\hline 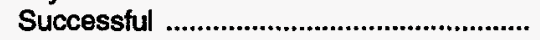 & 1,381 & 1,531 & 328 & 392 & 1,053 & 1,139 \\
\hline 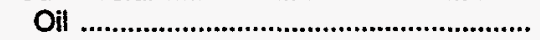 & 614 & 731 & 114 & 137 & 500 & 594 \\
\hline 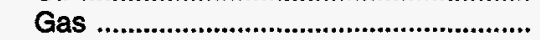 & 767 & 800 & 214 & 255 & 553 & 545 \\
\hline Subtotal & 3,666 & 3,484 & 581 & 696 & 3,085 & 2,787 \\
\hline 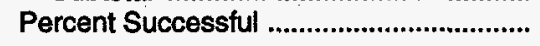 & 37.7 & 43.9 & 56.5 & 56.3 & 34.1 & 40.9 \\
\hline \multicolumn{7}{|l|}{ Development } \\
\hline 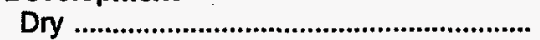 & 3,085 & 2,494 & 220 & 280 & 2,865 & 2,214 \\
\hline 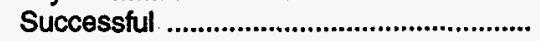 & 14,364 & 12,715 & 4,115 & 4,311 & 10,249 & 8,404 \\
\hline Oil & 6,104 & 6,158 & 2,130 & 2,059 & 3,974 & 4,099 \\
\hline Gas & 8,260 & 6,557 & 1,985 & 2,252 & 6,275 & 4,305 \\
\hline 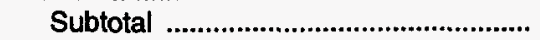 & 17,449 & 15,209 & 4,335 & 4,591 & 13,114 & 10,618 \\
\hline Percent Successtul .......................................... & 82.3 & 83.6 & 94.9 & 93.9 & 78.2 & 79.1 \\
\hline 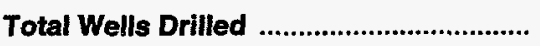 & 21,114 & 18,693 & 4,916 & 5,287 & 16,198 & 13,406 \\
\hline
\end{tabular}

Note: Sum of components may not equal total due to independent rounding.

Sources: Industry data - Special compilation provided by the Office of Oil and Gas, Energy Information Administration. Totals are based on data which appeared in the Energy Information Administration's Monthly Energy Review, September 1996, p. 83. FRS companies data - Energy Information Administration, Form ElA-28. 
Table B24. Completed Well Costs, Oil, Gas, and Dry, for FRS Companies and U.S. Industry, 1994 and 1995

\begin{tabular}{|c|c|c|c|c|c|c|c|c|}
\hline \multirow{2}{*}{$\begin{array}{c}\text { Drilling } \\
\text { and } \\
\text { Equipping Measures }\end{array}$} & \multicolumn{3}{|c|}{ FRS Companies } & \multicolumn{3}{|c|}{ U.S. Industry } & \multicolumn{2}{|c|}{$\begin{array}{l}\text { FRS as a Percent of } \\
\text { U.S. Industry }\end{array}$} \\
\hline & 1994 & 1995 & $\begin{array}{l}\text { Percent } \\
\text { Change }\end{array}$ & 1994 & 1995 & $\begin{array}{l}\text { Percent } \\
\text { Change }\end{array}$ & 1994 & 1995 \\
\hline
\end{tabular}

\section{Exploration}

Oil Wells

Drilling and Equipping Costs ${ }^{1}$..................... $\quad 138.0$

Wells Completed ........................................ $\quad 113.8$

Cost per Well (thousand dollars)

Average Depth (thousand feet)

Cost per Foot (dollars)

1,213

8.2

148.71

Gas Wells

Drilling and Equipping Costs 1

Wells Completed

Cost per Well (thousand dollars)

Average Depth (thousand feet)

Cost per Foot (dollars)

Dry Holes

Drilling and Equipping Costs 1

Wells Completed

Cost per Well (thousand dollars)

Average Depth (thousand feet)

Cost per Foot (dollars)

\section{Development}

Oil Wells

Drilling and Equipping Costs 1

Wells Completed

Cost per Well (thousand dollars)

Average Depth (thousand feet)

Cost per Foot (dollars)

Gas Wells

Drilling and Equipping Costs 1

Wells Completed

Cost per Well (thousand dollars)

Average Depth (thousand feet)

Cost per Foot (dollars)

\section{0}

213.8

1,871

9.5

196.85

236.0
136.6
1,728
9.1
189.71

71.0
20.0
42.5
11.7
27.6

447.0

254.5

1,756

8.5

207.14

11.8

19.0

$-6.1$

-10.8
5.2

926.0

252.9

3,662

10.3

354.79

675.0

303.9

2,221

8.9

250.93

\section{$-27.1$}

20.2

$-39.3$

$-14.2$

$-29.3$

$1,735.0$

$2,130.3$

$1,643.0$

$2,059.2$

798

5.6

146.22

5.7

$-5.3$

$-3.3$

$-2.0$

-2.0
1.5

$-3.5$

141.14

$1,727.0$

$1,703.0$

$2,251.6$

1,985

870

7.0

123.53

756

110.02

$-1.4$

13.4

$-13.1$

$-2.4$

$-10.9$

Dry Holes

Drilling and Equipping Costs 1

Wells Completed

Cost per Well (thousand dollars)

Average Depth (thousand feet)

Cost per Foot (dollars)

$\begin{array}{rrr}191.0 & 197.0 & 3.1 \\ 219.6 & 279.7 & 27.4 \\ 870 & 704 & -19.0 \\ 5.9 & 6.1 & 2.9 \\ 146.81 & 115.54 & -21.3\end{array}$

$6,104.0$

5.7

$6,158.0$

$-$

$\begin{array}{ccc}- & - & - \\ 614.0 & 731.0 & 19.1 \\ - & - & - \\ - & 6.8 & 4.6\end{array}$

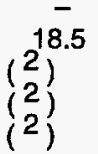

$\left(\begin{array}{l}2 \\ 2 \\ 2 \\ 2\end{array}\right)$

$\begin{array}{cc}767.0 & 800.0 \\ - & - \\ 6.4 & 6.6 \\ - & -\end{array}$

$\overline{4} .3$
-
3.1

27.9
$\left(\begin{array}{l}2 \\ 2 \\ 2\end{array}\right)$
$\left(\begin{array}{l}5 \\ )\end{array}\right.$

$\left(_{\left(\begin{array}{l}31.8 \\ 2 \\ 2 \\ 2\end{array}\right)}^{-}\right.$

$\begin{array}{cc}- & - \\ 2,285.0 & 1,952.0 \\ - & - \\ - & 6.0\end{array}$
$-14.6$
$-0$
0.0
-

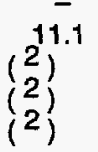

$\left(\begin{array}{l}2 \\ 2 \\ 2 \\ 2\end{array}\right)$

$8,260$.

0.0

$6,55 \overline{7 .}$

6.6

6.5

-20.6
-1.5
-

-
0.9
-7.0

$\left(\begin{array}{l}2{ }^{-} \\ 2 \\ (2\end{array}\right)^{-}$

$\left(\begin{array}{l}33.4 \\ 2 \\ 2 \\ 2\end{array}\right)$

$-$
$3,085$.
5.5

2,4940

$2,494.0$

5.5

-
-19.2
-
0.0
- $\left(\begin{array}{l}2^{34.3} \\ 2 \\ 2\end{array}\right)$

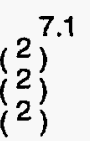

1 Million Dollars.

2 Not meaningful.

- = Not available.

Sources: Industry data - Special compilation provided by the Office of Oil and Gas, Energy Information Administration. Totals are based on data which appeared in the Energy Information Administration's Monthly Energy Review, September 1996, p. 83. FRS companies data - Energy Information Administration, Form EIA-28. 
Table B25. Completed Well Costs, Oil, Gas, and Dry, Onshore and Offshore, for FRS Companies, 1994 and 1995

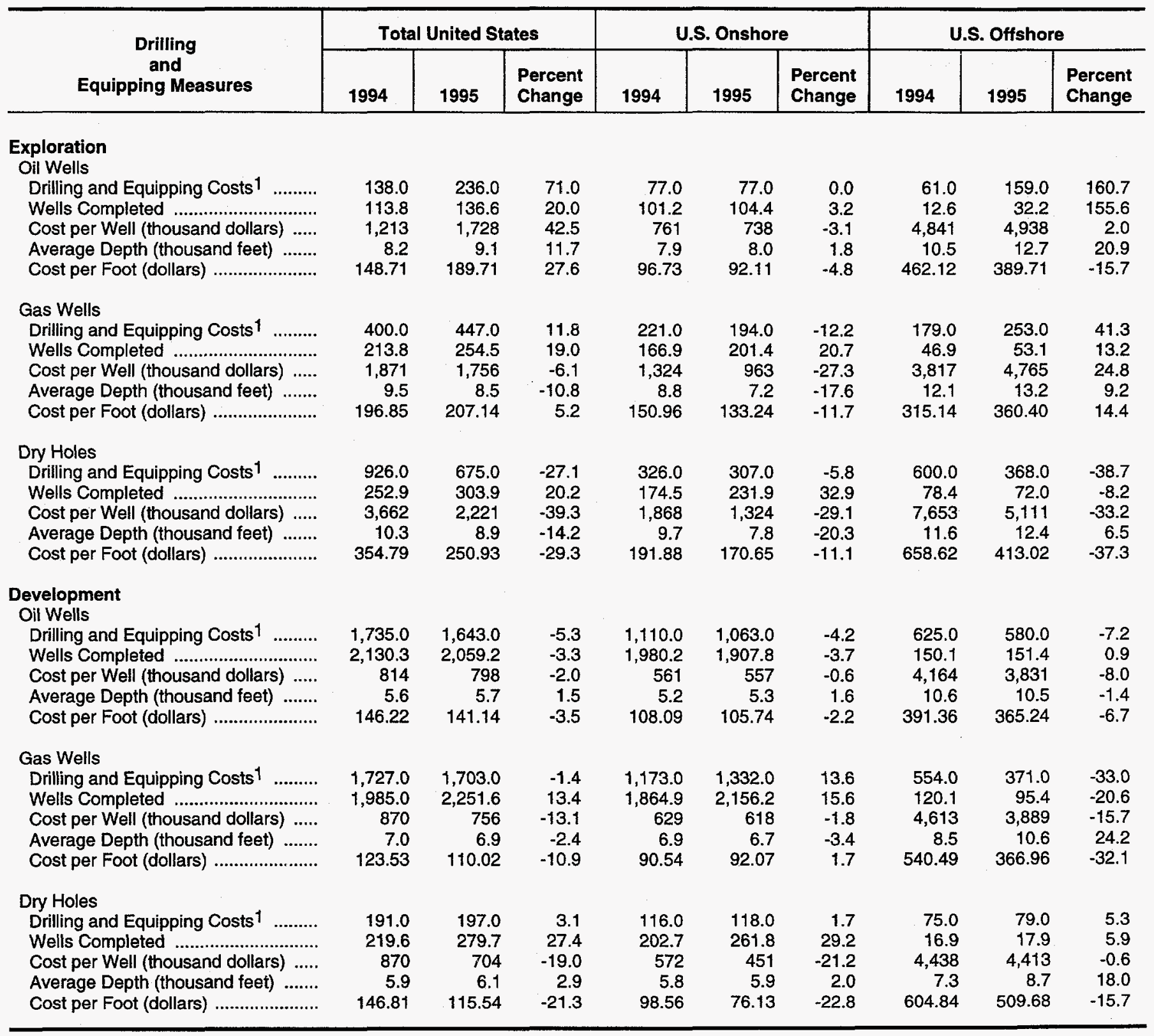

1 Million Dollars.

Source: Energy Information Administration, Form EIA-28. 
Table B26. U.S. Net Wells Completed, and Net In-Progress Wells for FRS Companies, 1989-1995

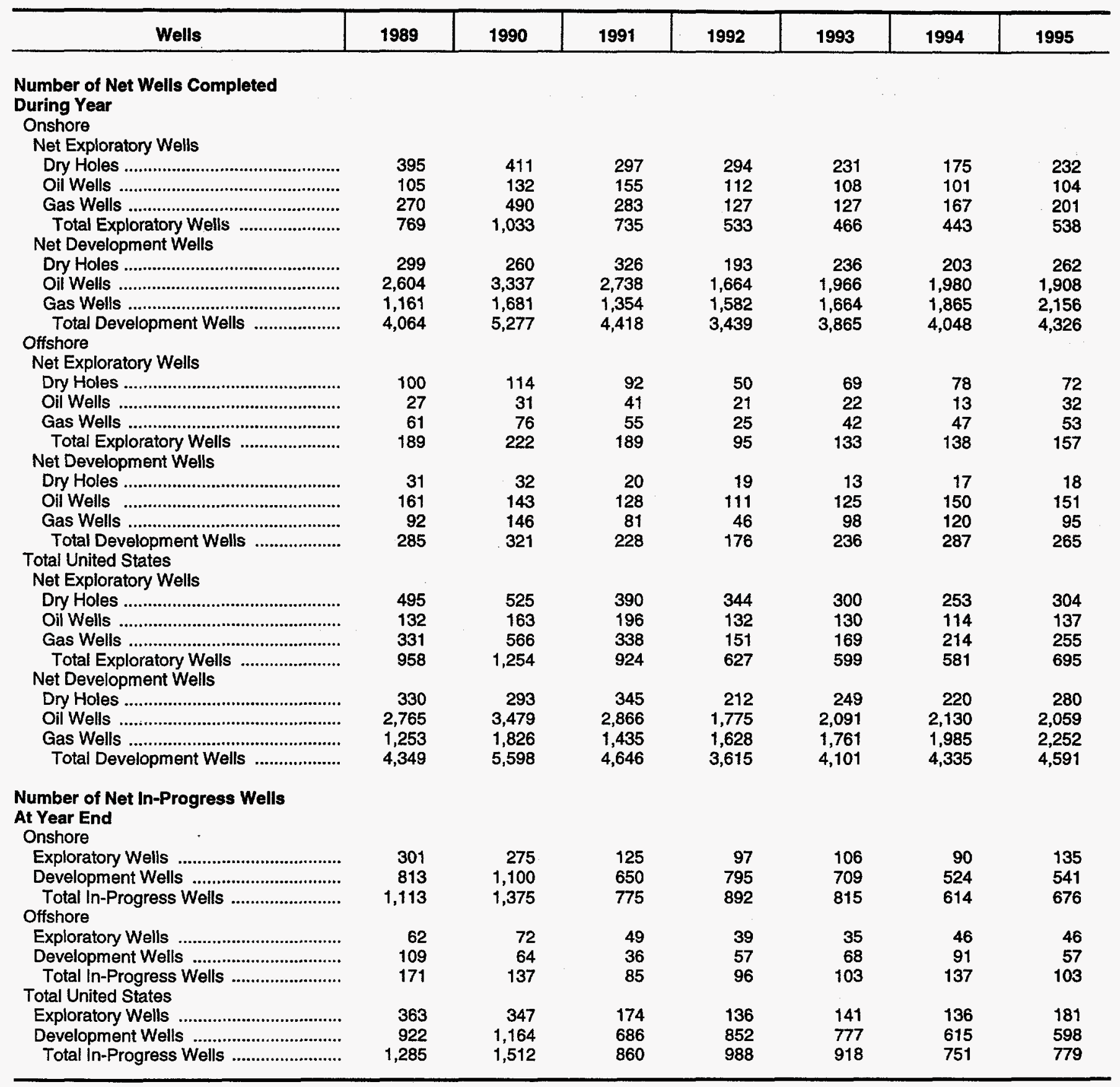

Source: Energy Information Administration, Form EIA-28. 
Table B27. Exploration and Development Net Drilling Footage for FRS Companies, 1989-1995 (Thousand Feet)

\begin{tabular}{|c|c|c|c|c|c|c|c|}
\hline $\begin{array}{l}\text { Exploration, Development, and } \\
\text { Production Statistics }\end{array}$ & 1989 & 1990 & 1991 & 1992 & 1993 & 1994 & 1995 \\
\hline $\begin{array}{l}\text { Onshore } \\
\text { Exploratory Well Footage }\end{array}$ & \multicolumn{6}{|c|}{ Onshore } & \\
\hline 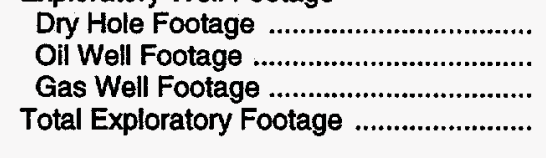 & $\begin{array}{r}3,143 \\
888 \\
1,520 \\
5,551\end{array}$ & $\begin{array}{l}3,660 \\
1,069 \\
2,126 \\
6,855\end{array}$ & $\begin{array}{l}2,611 \\
1,208 \\
1,711 \\
5,530\end{array}$ & $\begin{array}{r}2,623 \\
964 \\
1,035 \\
4,622\end{array}$ & $\begin{array}{r}2,341 \\
974 \\
1,072 \\
4,387\end{array}$ & $\begin{array}{r}1,699 \\
796 \\
1,464 \\
3,959\end{array}$ & $\begin{array}{r}1,799 \\
836 \\
1,456 \\
4,091\end{array}$ \\
\hline 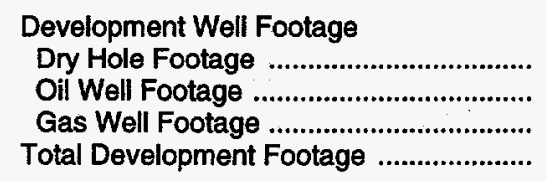 & $\begin{array}{r}1,858 \\
11,289 \\
7,079 \\
20,226\end{array}$ & $\begin{array}{r}1,758 \\
14,442 \\
10,593 \\
26,793\end{array}$ & $\begin{array}{r}1,130 \\
12,928 \\
7,388 \\
21,446\end{array}$ & $\begin{array}{r}1,270 \\
9,192 \\
10,589 \\
21,051\end{array}$ & $\begin{array}{r}1,429 \\
11,407 \\
11,558 \\
24,394\end{array}$ & $\begin{array}{r}1,177 \\
10,269 \\
12,955 \\
24,401\end{array}$ & $\begin{array}{r}1,550 \\
10,053 \\
14,468 \\
26,071\end{array}$ \\
\hline 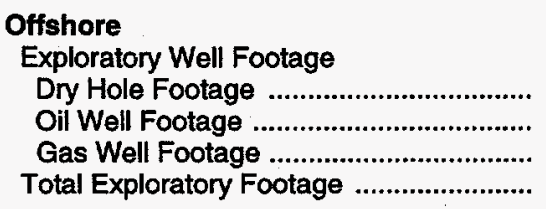 & $\begin{array}{r}1,086 \\
285 \\
694 \\
2,065\end{array}$ & $\begin{array}{r}1,268 \\
400 \\
809 \\
2,477\end{array}$ & $\begin{array}{r}1,087 \\
487 \\
647 \\
2,221\end{array}$ & $\begin{array}{r}755 \\
275 \\
321 \\
1,351\end{array}$ & $\begin{array}{r}710 \\
304 \\
488 \\
1,502\end{array}$ & $\begin{array}{r}911 \\
132 \\
568 \\
1,611\end{array}$ & $\begin{array}{r}891 \\
408 \\
702 \\
2,001\end{array}$ \\
\hline 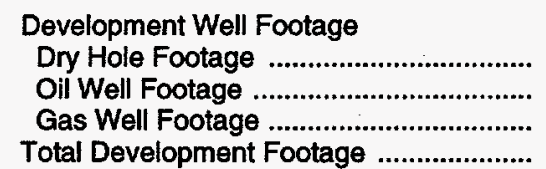 & $\begin{array}{r}260 \\
1,521 \\
983 \\
2,764\end{array}$ & $\begin{array}{r}201 \\
1,247 \\
1,074 \\
2,522\end{array}$ & $\begin{array}{r}202 \\
1,086 \\
711 \\
1,999\end{array}$ & $\begin{array}{r}172 \\
871 \\
466 \\
1,509\end{array}$ & $\begin{array}{r}158 \\
1,267 \\
975 \\
2,400\end{array}$ & $\begin{array}{r}124 \\
1,597 \\
1,025 \\
2,746\end{array}$ & $\begin{array}{r}155 \\
1,588 \\
1,011 \\
2,754\end{array}$ \\
\hline
\end{tabular}

Source: Energy Information Administration, Form EIA-28. 
Table B28. U.S. Net Producing Wells and U.S. Acreage for FRS Companies, 1989-1995

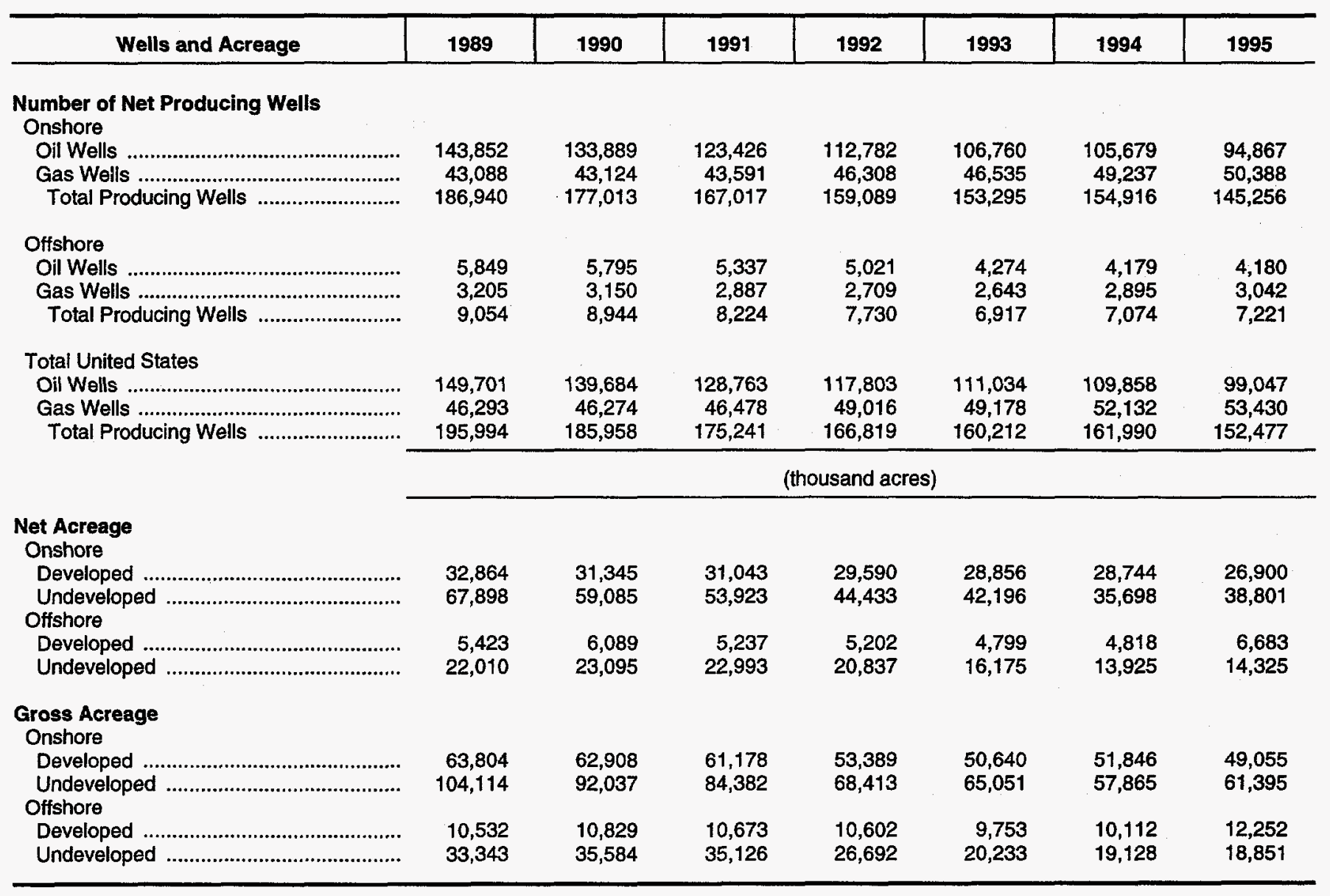

Source: Energy Information Administration, Form EIA-28. 
Table B29. U.S. Net Petroleum Acreage for FRS Companies, Ranked by Total Energy Assets, 1995 and Percent Change from 1994

\begin{tabular}{|c|c|c|c|c|c|c|}
\hline \multirow[b]{2}{*}{$\begin{array}{l}\text { Petroleum } \\
\text { Acreage }\end{array}$} & \multicolumn{2}{|c|}{ Undeveloped Acreage } & \multicolumn{2}{|c|}{ Developed Acreage } & \multicolumn{2}{|c|}{ Total Acreage } \\
\hline & $\begin{array}{l}\text { Thousand } \\
\text { Acres }\end{array}$ & $\begin{array}{c}\text { Percent } \\
\text { Change } \\
\text { from } 1994\end{array}$ & $\begin{array}{l}\text { Thousand } \\
\text { Acres }\end{array}$ & $\begin{array}{c}\text { Percent } \\
\text { Change } \\
\text { from } 1994\end{array}$ & $\begin{array}{l}\text { Thousand } \\
\text { Acres }\end{array}$ & $\begin{array}{c}\text { Percent } \\
\text { Change } \\
\text { from } 1994\end{array}$ \\
\hline \multicolumn{7}{|l|}{ Onshore } \\
\hline Top Four & 9,941 & -14.7 & 8,907 & -9.1 & 18,848 & -12.2 \\
\hline Five Through Twelve ................................. & 12,980 & -5.2 & 8,090 & -9.9 & 21,070 & -7.0 \\
\hline All Other & 15,880 & 53.3 & 9,903 & -0.6 & 25,783 & 26.9 \\
\hline 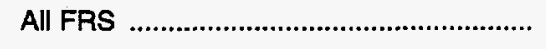 & 38,801 & 8.7 & 26,900 & -6.4 & 65,701 & 2.0 \\
\hline \multicolumn{7}{|l|}{ Offshore } \\
\hline Top Four & 3,176 & -11.9 & 2,138 & 0.6 & 5,314 & -7.2 \\
\hline 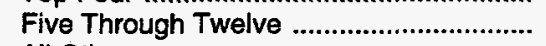 & 8,331 & 19.8 & 3,241 & 123.1 & 11,572 & 37.7 \\
\hline 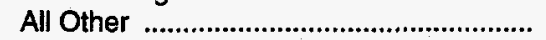 & 2,818 & -16.4 & 1,304 & 5.2 & 4,122 & -10.6 \\
\hline All FRS & 14,325 & 2.9 & 6,683 & 38.7 & 21,008 & 12.1 \\
\hline \multicolumn{7}{|l|}{ Total } \\
\hline 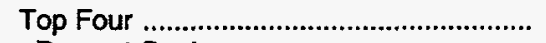 & 13,117 & -14.0 & 11,045 & -7.4 & 24,162 & -11.1 \\
\hline 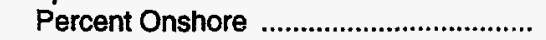 & 75.8 & -- & 80.6 & -- & 78.0 &.- \\
\hline 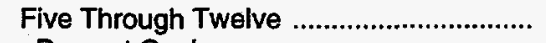 & 21,311 & 3.3 & 11,331 & 8.6 & 32,642 & 5.1 \\
\hline Percent Onshore & 60.9 & - & 71.4 & -- & 64.5 & -- \\
\hline All Other & 18,698 & 36.2 & 11,207 & 0.0 & 29,905 & 20.0 \\
\hline Percent Onshore & 84.9 & -- & 88.4 & -- & 86.2 & -- \\
\hline All FRS & 53,126 & 7.1 & 33,583 & 0.1 & 86,709 & 4.2 \\
\hline Percent Onshore & 73.0 & -- & 80.1 & -- & 75.8 & -. \\
\hline
\end{tabular}

-- Not applicable.

Source: Energy Information Administration, Form EIA-28. 
Table B30. U.S. Net Ownership Interest Petroleum Reserves and Production for FRS Companies and U.S. Industry, 1995

\begin{tabular}{|c|c|c|c|c|}
\hline \multirow{2}{*}{ Reserves and Production } & \multicolumn{2}{|c|}{$\begin{array}{l}\text { Crude Oil and } \\
\text { Natural Gas Liquids } \\
\text { (billion barrels) }\end{array}$} & \multicolumn{2}{|c|}{$\begin{array}{c}\text { Natural Gas } \\
\text { (trillion cubic feet) }\end{array}$} \\
\hline & $\begin{array}{c}\text { FRS } \\
\text { Companies }\end{array}$ & $\begin{array}{c}\text { U.S. } \\
\text { Industry }\end{array}$ & $\begin{array}{c}\text { FRS } \\
\text { Companies }\end{array}$ & $\begin{array}{c}\text { U.S. } \\
\text { Industry }\end{array}$ \\
\hline \multicolumn{5}{|l|}{ Onshore } \\
\hline 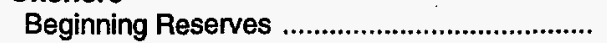 & 14.2 & 25.8 & 57.5 & 134.2 \\
\hline Ending Reserves & 13.7 & 25.6 & 58.3 & 134.8 \\
\hline Percent Change & -3.7 & -0.7 & 1.5 & 0.4 \\
\hline 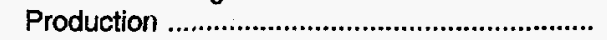 & 1.2 & 2.5 & 5.4 & 13.1 \\
\hline 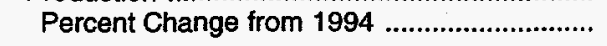 & -4.2 & -3.1 & 2.3 & -1.9 \\
\hline \multicolumn{5}{|l|}{ Offshore } \\
\hline Beginning Reserves & 2.8 & 3.8 & 20.7 & 29.6 \\
\hline Ending Reserves & 3.1 & 4.1 & 21.0 & 30.4 \\
\hline Percent Change & 9.0 & 8.2 & 1.3 & 2.5 \\
\hline 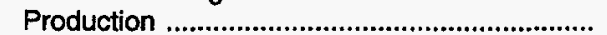 & 0.3 & 0.5 & 2.7 & 4.9 \\
\hline Percent Change from 1994 & 10.6 & 5.5 & -2.3 & -2.0 \\
\hline \multicolumn{5}{|l|}{ Total } \\
\hline Beginning Reserves & 17.0 & 29.6 & 78.2 & 163.8 \\
\hline Ending Reserves & 16.7 & 29.8 & 79.3 & 165.1 \\
\hline Percent Change & -1.6 & 0.4 & 1.4 & 0.8 \\
\hline 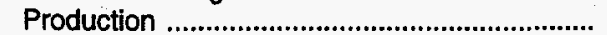 & 1.6 & 3.0 & 8.1 & 18.0 \\
\hline Percent Change from 1994 & -1.5 & -1.8 & 0.7 & -1.9 \\
\hline
\end{tabular}

Note: "Net Ownership Interest" is defined as net working interest plus own royalty interest.

Sources: Industry data - Energy Information Administration Form ElA-23; see U.S. Crude Oil, Natural Gas, and Natural Gas Liquids

Reserves Annual Report, 1994 and 1995 (October 1995 and November 1996). FRS companies data - Energy Information Administration, Form EIA-28. 
Table B31. Proved Petroleum Reserves for FRS Companies, United States and Foreign, 1995

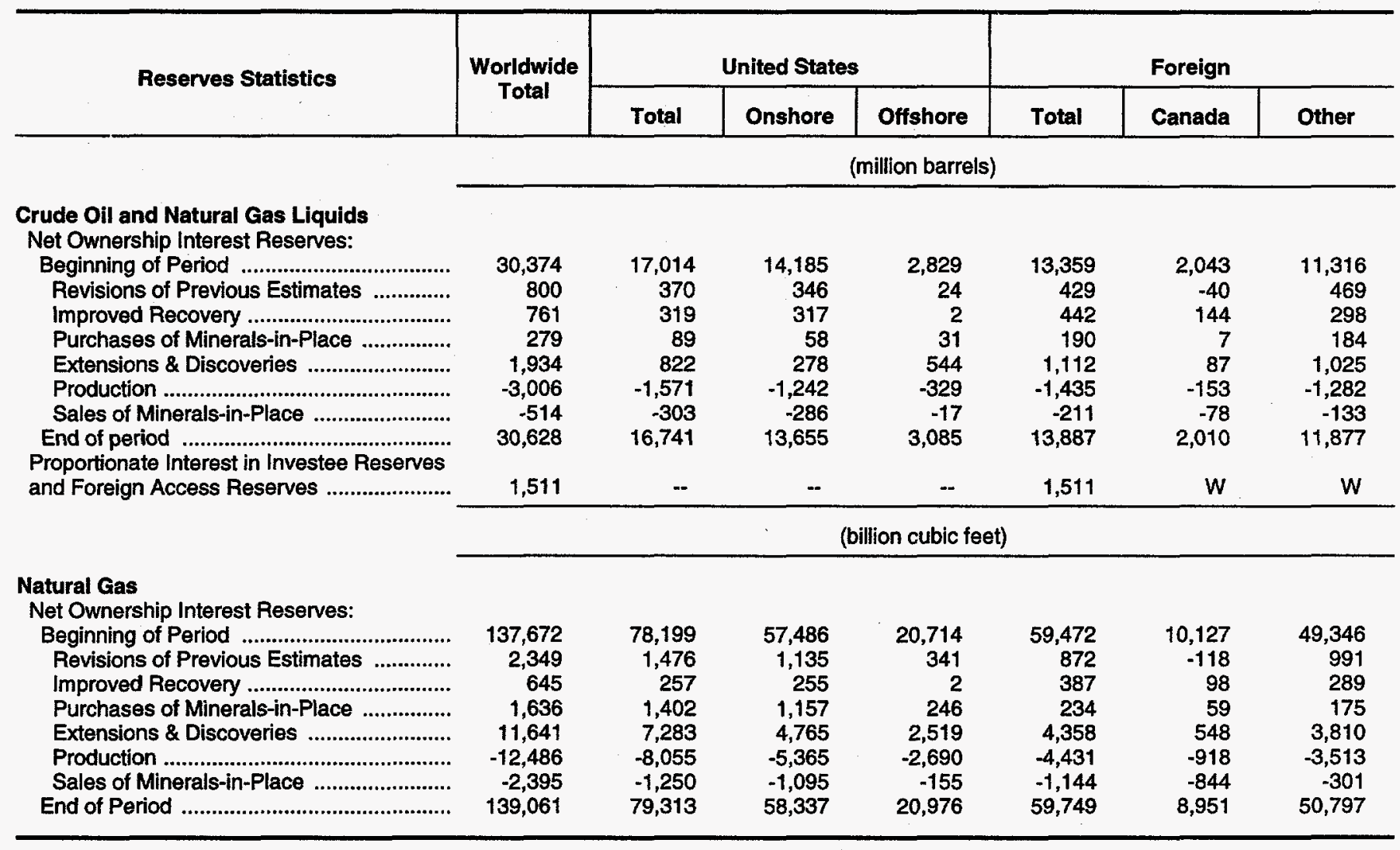

$\overline{\text { W }}=$ Not applicable.

W = Data withheld to avoid disclosure.

Source: Energy Information Administration, Form EIA-28. 
Table B32. U.S. Reserve Additions, Exploration and Development Expenditures, and Expenditures per Barrel of Reserve Additions for FRS Companies Ranked by Total Energy Assets and for U.S. Industry, 1993-1995

\begin{tabular}{|c|c|c|c|c|c|c|c|c|c|}
\hline \multirow{2}{*}{$\begin{array}{l}\text { Reserve Additions, } \\
\text { Expenditures, and Wells }\end{array}$} & \multicolumn{3}{|c|}{1993} & \multicolumn{3}{|c|}{1994} & \multicolumn{3}{|c|}{1995} \\
\hline & Onshore & Offshore & Total & Onshore & Offshore & Total & Onshore & Offshore & Total \\
\hline & \multicolumn{9}{|c|}{ (million barrels) } \\
\hline \multirow[t]{2}{*}{ 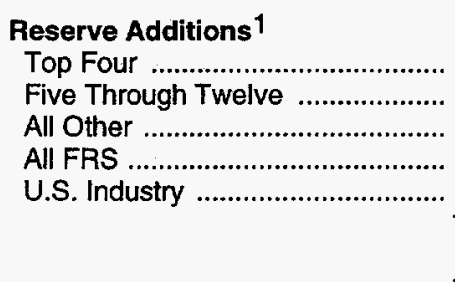 } & $\begin{array}{r}427.8 \\
724.3 \\
310.9 \\
1,463.0 \\
3,389.1 \\
\end{array}$ & $\begin{array}{r}295.2 \\
318.9 \\
236.5 \\
850.6 \\
1,424.5 \\
\end{array}$ & $\begin{array}{r}723.0 \\
1,043.2 \\
547.4 \\
2,313.6 \\
4,813.6 \\
\end{array}$ & $\begin{array}{r}447.6 \\
724.6 \\
353.2 \\
1,525.4 \\
4,423.3\end{array}$ & $\begin{array}{r}464.7 \\
424.3 \\
177.2 \\
1,066.3 \\
1,598.2 \\
\end{array}$ & $\begin{array}{r}912.4 \\
1,148.9 \\
530.4 \\
2,591.7 \\
6,021.4\end{array}$ & $\begin{array}{r}648.5 \\
885.8 \\
496.9 \\
2,031.2 \\
4,741.8\end{array}$ & $\begin{array}{r}433.6 \\
457.3 \\
186.8 \\
1,077.8 \\
1,816.2\end{array}$ & $\begin{array}{r}1,082.1 \\
1,343.1 \\
683.7 \\
3,109.0 \\
6,558.0\end{array}$ \\
\hline & \multicolumn{9}{|c|}{ (million dollars) } \\
\hline \multirow{4}{*}{ 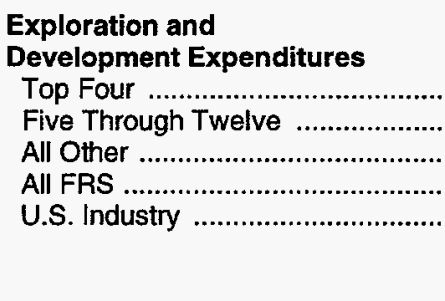 } & & & & & & & & & \\
\hline & $\begin{array}{l}2,173.0 \\
2,848.0 \\
1,731.0 \\
6,752.0\end{array}$ & $\begin{array}{l}1,031.0 \\
1,504.0 \\
1,046.0 \\
\mathbf{3}, 581.0\end{array}$ & $\begin{array}{r}3,204.0 \\
4,352.0 \\
2,777.0 \\
10,333.0\end{array}$ & $\begin{array}{l}1,850.0 \\
2,829.0 \\
2,140.0 \\
6,819.0\end{array}$ & $\begin{array}{l}1,120.0 \\
1,914.0 \\
1,159.0 \\
4,193.0\end{array}$ & $\begin{array}{r}2,970.0 \\
4,743.0 \\
3,299.0 \\
11,012.0\end{array}$ & $\begin{array}{l}1,903.0 \\
3,031.0 \\
1,948.0 \\
6,882.0\end{array}$ & $\begin{array}{l}1,493.0 \\
2,036.0 \\
1,043.0 \\
4,572.0\end{array}$ & $\begin{array}{r}3,396.0 \\
5,067.0 \\
2,991.0 \\
11,454.0\end{array}$ \\
\hline & - & - & - & - & - & - & - & - & - \\
\hline & \multicolumn{9}{|c|}{ (number of wells) } \\
\hline Wells Completed & & & & & & & & & \\
\hline 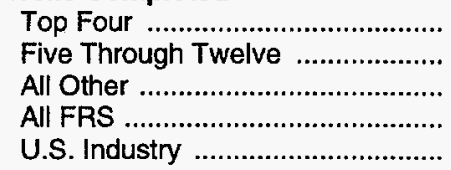 & $\begin{array}{r}1,214.4 \\
1,778.2 \\
1,338.5 \\
4,331.1 \\
24,519.0\end{array}$ & $\begin{array}{l}139.0 \\
124.6 \\
104.5 \\
368.8 \\
798.0\end{array}$ & $\begin{array}{r}1,353.4 \\
1,902.8 \\
1,443.0 \\
4,699.9 \\
25,318.0\end{array}$ & $\begin{array}{r}1,211.9 \\
1,878.5 \\
1,400.0 \\
4,490.4 \\
19,372.0\end{array}$ & $\begin{array}{l}125.0 \\
186.7 \\
113.3 \\
425.0 \\
741.0\end{array}$ & $\begin{array}{r}1,336.9 \\
2,065.2 \\
1,513.3 \\
4,915.4 \\
21,114.0\end{array}$ & $\begin{array}{r}1,425.6 \\
1,835.2 \\
1,602.7 \\
4,863.5 \\
18,183.0\end{array}$ & $\begin{array}{l}146.6 \\
146.9 \\
128.5 \\
422.0 \\
511.0\end{array}$ & $\begin{array}{r}1,572.2 \\
1,982.1 \\
1,731.2 \\
5,285.5 \\
18,693.0\end{array}$ \\
\hline
\end{tabular}

(dollars per barrel)

\begin{tabular}{|c|c|c|c|c|c|c|c|c|c|}
\hline $\begin{array}{l}\text { Exploration and Development } \\
\text { Expenditures per Barrel of } \\
\text { Reserve Additions }\end{array}$ & & & & & & & & & \\
\hline Top Four & 5.08 & 3.49 & 4.43 & 4.13 & 2.41 & 3.26 & 2.93 & 3.44 & 3.14 \\
\hline Five Through Twelve ..................... & 3.93 & 4.72 & 4.17 & 3.90 & 4.51 & 4.13 & 3.42 & 4.45 & 3.77 \\
\hline 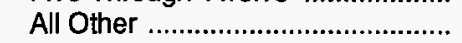 & 5.57 & 4.42 & 5.07 & 6.06 & 6.54 & 6.22 & 3.92 & 5.58 & 4.37 \\
\hline All FRS & 4.62 & 4.21 & 4.47 & 4.47 & 3.93 & 4.25 & 3.39 & 4.24 & 3.68 \\
\hline 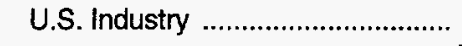 & - & - & - & - & - & - & - & - & - \\
\hline & & & & & isand barr & & & & \\
\hline $\begin{array}{l}\text { Reserve Additions per } \\
\text { Well Completed }\end{array}$ & & & & & & & & & \\
\hline 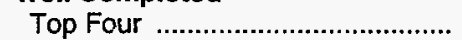 & 352.3 & $2,123.9$ & 534.2 & 369.4 & $3,717.9$ & 682.5 & 454.9 & $2,958.0$ & 688.3 \\
\hline Five Through Twelve ...................... & 407.3 & $2,559.5$ & 548.2 & 385.7 & $2,272.7$ & 556.3 & 482.7 & $3,113.1$ & 677.6 \\
\hline 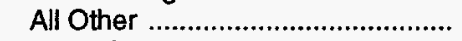 & 232.3 & $2,263.3$ & 379.4 & 252.3 & $1,564.4$ & 350.5 & 310.0 & $1,454.0$ & 394.9 \\
\hline All FRS & 337.8 & $2,306.5$ & 492.3 & 339.7 & $2,508.9$ & 527.3 & 417.6 & $2,554.0$ & 588.2 \\
\hline 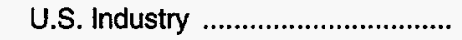 & 138.2 & $1,785.1$ & 190.1 & 228.3 & $2,156.8$ & 285.2 & 260.8 & $3,554.2$ & 350.8 \\
\hline
\end{tabular}

1 Excludes net purchases of minerals in place; includes crude oil and natural gas liquids (measured in millions of barrels) and natural gas (measured in millions of barrels of crude equivalent). The conversion factor for natural gas is 0.178 barrels of crude / 1000 cubic feet. Reserve additions include the net of corrections and adjustments.

- Not available.

Sources: Reserve additions - Energy Information Administration Form EIA-23; see U.S. Crude Oil, Natural Gas, and Natural Gas Liquids Resenves, 1993, 1994, and 1995 Annual Reports. Wells completed - special compilation provided by the Office of Oil and Gas, Energy Information Administration. Totals are based on data which appeared in the Energy Information's Monthly Energy Review, September 1996, $\mathrm{p}$. 83. FRS companies data - Energy Information Administration, Form EIA-28. 
Table B33. Foreign Petroleum Exploration, Development, Reserves, and Production Statistics by Geographic Area for FRS Companies and Foreign Industry, 1995, and Percent Change from 1994

\begin{tabular}{|c|c|c|c|c|c|c|c|}
\hline \multicolumn{8}{|l|}{$\begin{array}{l}\text { Crude Oil and NGL Production } 2 \\
\text { (million barrels) }\end{array}$} \\
\hline FRS Companies & $1,550.2$ & 152.5 & 591.3 & 332.7 & 109.6 & 264.8 & 99.3 \\
\hline Percent Change & 4.5 & 51.9 & 6.3 & -0.8 & 0.7 & 3.6 & 2.5 \\
\hline \multicolumn{8}{|l|}{ Wells Completed } \\
\hline FRS Companies & $1,768.1$ & $1,049.9$ & 177.7 & 102.9 & 59.1 & 231.5 & 147.0 \\
\hline Percent Change & 12.7 & 15.5 & 22.9 & 11.4 & -19.3 & -3.7 & 33.9 \\
\hline Foreign Industry & $23,256.0$ & $10,943.0$ & $6,822.0$ & 609.0 & 651.0 & $1,151.0$ & $3,080.0$ \\
\hline Percent Change & -2.5 & -8.0 & -4.2 & 16.9 & 42.5 & 0.3 & 13.2 \\
\hline \multicolumn{8}{|l|}{$\begin{array}{l}\text { Exploration and Development } \\
\text { Expenditures } \\
\text { (million dollars) }\end{array}$} \\
\hline 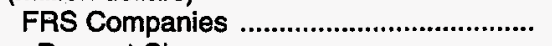 & $13,171.0$ & $1,899.0$ & $5,563.0$ & $2,043.0$ & 361.0 & $2,430.0$ & 875.0 \\
\hline Percent Change & 10.6 & 3.5 & 17.5 & 46.8 & -18.9 & -11.9 & 17.8 \\
\hline \multicolumn{8}{|l|}{$\begin{array}{l}\text { Crude Oil and NGL Reserve } \\
\text { Interests } \\
\text { (million barrels) }\end{array}$} \\
\hline FRS Companies & $15,398.7$ & $2,017.7$ & $5,806.8$ & $2,825.0$ & $1,800.6$ & $2,120.6$ & 827.9 \\
\hline Percent Change & 3.3 & -1.5 & 4.3 & 14.6 & 2.7 & -5.4 & -0.5 \\
\hline
\end{tabular}

1 OECD Europe combined with the former Soviet Union and Eastern Europe to avoid disclosure. Prior to 1993, only OECD Europe is included in this region.

2 Crude oil plus natural gas liquids. Includes ownership interest production and foreign access production.

3 Foreign Industry levels defined as total activity outside of the United States except the People's Republic of China.

4 Success Rate defined as the total number of successful well completions during the period divided by the total number of wells drilled.

5 Includes net ownership interest reserves (90.2 percent) and "Other Access" reserves (9.8 percent). "Other Access" reserves include proportional interest in investee reserves and foreign access reserves.

Note: Sum of components may not equal total due to independent rounding.

Sources: FRS Companies - Energy Information Administration, Form ElA-28. Industry data - World Oil, August 1996, and Energy Information Administration, International Energy Annual, 1995. 
Table B34. Foreign Exploration and Development Expenditures by Region for FRS Companies, 1989-1995 (Million Dollars)

\begin{tabular}{|c|c|c|c|c|c|c|c|}
\hline Foreign Expenditures by Region & 1989 & 1990 & 1991 & 1992 & 1993 & 1994 & 1995 \\
\hline \multicolumn{8}{|l|}{ Exploration Expenditures } \\
\hline 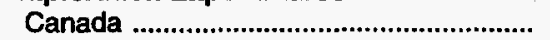 & 1,141 & 753 & 661 & 336 & 403 & 573 & 493 \\
\hline OECD Europe ........................................... & 1,132 & 2,233 & 2,192 & 1,544 & 1,313 & 1,063 & 1,242 \\
\hline Former Soviet Union and E. Europe ........ & 0 & 0 & 0 & 0 & 163 & 204 & 181 \\
\hline 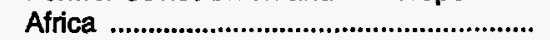 & 585 & 618 & 680 & 738 & 599 & 678 & 707 \\
\hline 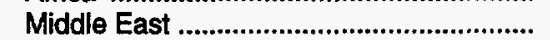 & 197 & 302 & 258 & 273 & 225 & 104 & 90 \\
\hline Other Eastern Hemisphere ......................... & 1,186 & 1,017 & 1,028 & 869 & 736 & 888 & 1,016 \\
\hline Other Western Hemisphere ....................... & 304 & 327 & 435 & 283 & 240 & 320 & 431 \\
\hline Total Foreign Exploration Expenditures .... & 4,545 & 5,250 & 5,254 & 4,043 & 3,679 & 3,830 & 4,160 \\
\hline \multicolumn{8}{|l|}{ Development Expenditures } \\
\hline 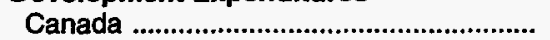 & 5,125 & 1,065 & 1,070 & 770 & 1,156 & 1,262 & 1,406 \\
\hline OECD Europe & 2,407 & 4,383 & 4,643 & 5,252 & 4,169 & 3,376 & 3,962 \\
\hline Former Soviet Union and E. Europe ........ & 0 & 0 & 0 & 0 & 100 & 93 & 178 \\
\hline Africa & 439 & 807 & 845 & 655 & 873 & 714 & 1,336 \\
\hline 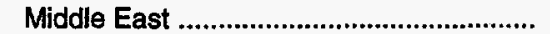 & 209 & 296 & 233 & 285 & 460 & 341 & 271 \\
\hline Other Eastern Hemisphere .......................... & 1,098 & 1,416 & 1,359 & 1,540 & 1,733 & 1,870 & 1,414 \\
\hline Other Western Hemisphere ....................... & 305 & 343 & 300 & 364 & 376 & 423 & 444 \\
\hline Total Foreign Development Expenditures & 9,583 & 8,310 & 8,450 & 8,866 & 8,867 & 8,079 & 9,011 \\
\hline \multicolumn{8}{|l|}{$\begin{array}{l}\text { Total Exploration and Development } \\
\text { Expenditures }\end{array}$} \\
\hline 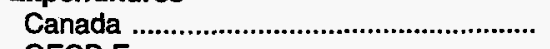 & 6,266 & 1,818 & 1,731 & 1,106 & 1,559 & 1,835 & 1,899 \\
\hline OECD Europe & 3,539 & 6,616 & 6,835 & 6,796 & 5,482 & 4,439 & 5,204 \\
\hline Former Soviet Union and E. Europe ........ & 0 & 0 & 0 & 0 & 263 & 297 & 359 \\
\hline Africa & 1,024 & 1,425 & 1,525 & 1,393 & 1,472 & 1,392 & 2,043 \\
\hline 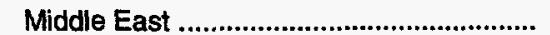 & 406 & 598 & 491 & 558 & 685 & 445 & 361 \\
\hline Other Eastern Hemisphere ............................ & 2,284 & 2,433 & 2,387 & 2,409 & 2,469 & 2,758 & 2,430 \\
\hline Other Western Hemisphere .......................... & 609 & 670 & 735 & 647 & 616 & 743 & 875 \\
\hline \multicolumn{8}{|l|}{ Total Foreign Exploration and } \\
\hline Development Expenditures ........................... & 14,128 & 13,560 & 13,704 & 12,909 & 12,546 & 11,909 & 13,171 \\
\hline
\end{tabular}

Source: Energy Information Administration, Form EIA-28. 
Table B35. Distribution of Foreign Exploration and Development Expenditures for FRS Companies Ranked by Total Energy Assets, 1995, and Percent Change from 1994

\begin{tabular}{|c|c|c|c|c|c|c|}
\hline $\begin{array}{l}\text { Exploration and Development } \\
\text { Expenditures }\end{array}$ & $\begin{array}{l}\text { Total } \\
\text { Foreign }\end{array}$ & Canada & $\begin{array}{c}\text { Europe and } \\
\text { Former } \\
\text { Soviet Union } 1\end{array}$ & $\begin{array}{c}\text { Africa } \\
\text { and } \\
\text { Mideast }\end{array}$ & $\begin{array}{c}\text { Other } \\
\text { Eastern } \\
\text { Hemisphere }\end{array}$ & $\begin{array}{c}\text { Other } \\
\text { Western } \\
\text { Hemisphere }\end{array}$ \\
\hline & \multicolumn{6}{|c|}{ (million dollars) } \\
\hline \multirow[t]{2}{*}{ 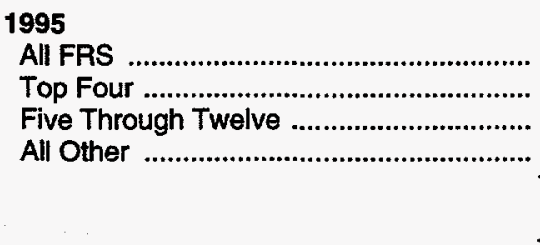 } & $\begin{array}{r}13,171.0 \\
7,419.0 \\
3,767.0 \\
1,985.0\end{array}$ & $\begin{array}{r}1,899.0 \\
1,141.0 \\
526.0 \\
232.0\end{array}$ & $\begin{array}{l}5,563.0 \\
3,155.0 \\
1,329.0 \\
1,079.0\end{array}$ & $\begin{array}{r}2,404.0 \\
1,561.0 \\
696.0 \\
147.0\end{array}$ & $\begin{array}{r}2,430.0 \\
1,320.0 \\
633.0 \\
477.0\end{array}$ & $\begin{array}{r}875.0 \\
242.0 \\
583.0 \\
50.0\end{array}$ \\
\hline & \multicolumn{6}{|c|}{ (percent) } \\
\hline \multicolumn{7}{|l|}{ Distribution 1995} \\
\hline 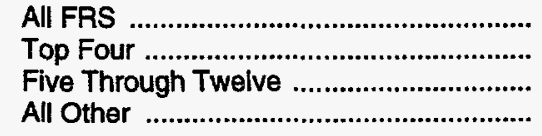 & $\begin{array}{l}100.0 \\
100.0 \\
100.0 \\
100.0\end{array}$ & $\begin{array}{l}14.4 \\
15.4 \\
14.0 \\
11.7\end{array}$ & $\begin{array}{l}42.2 \\
42.5 \\
35.3 \\
54.4\end{array}$ & $\begin{array}{r}18.3 \\
21.0 \\
18.5 \\
7.4\end{array}$ & $\begin{array}{l}18.4 \\
17.8 \\
16.8 \\
24.0\end{array}$ & $\begin{array}{r}6.6 \\
3.3 \\
15.5 \\
2.5\end{array}$ \\
\hline \multicolumn{7}{|l|}{ Change from 1994} \\
\hline 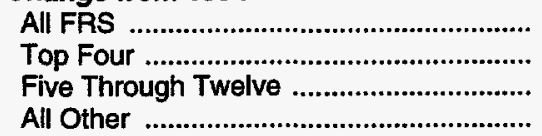 & $\begin{array}{r}10.6 \\
20.0 \\
-3.8 \\
9.4\end{array}$ & $\begin{array}{r}3.5 \\
13.9 \\
-2.0 \\
-21.6\end{array}$ & $\begin{array}{r}17.5 \\
25.2 \\
-1.6 \\
24.7\end{array}$ & $\begin{array}{r}30.9 \\
63.1 \\
-5.2 \\
0.7\end{array}$ & $\begin{array}{r}-11.9 \\
-17.4 \\
-9.8 \\
4.4\end{array}$ & $\begin{array}{r}17.8 \\
137.3 \\
-1.2 \\
-2.0\end{array}$ \\
\hline
\end{tabular}

1 OECD Europe combined with the former Soviet Union and Eastern Europe to avoid disclosure. Prior to 1993, only OECD Europe is included in this region.

Source: Energy Information Administration, Form ElA-28. 
Table B36. Number of Net Wells Completed, Net In-Progress Wells, and Net Producing Wells in Foreign Areas for FRS Companies, 1989-1995

\begin{tabular}{|c|c|c|c|c|c|c|c|}
\hline Number of Wells & 1989 & 1990 & 1991 & 1992 & 1993 & 1994 & 1995 \\
\hline \multicolumn{8}{|l|}{ Canada } \\
\hline \multicolumn{8}{|l|}{$\begin{array}{l}\text { Net Wells Completed During Year } \\
\text { Exploratory Wells }\end{array}$} \\
\hline 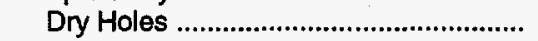 & 113.9 & 104.9 & 101.3 & 65.1 & 71.7 & 111.2 & 107.5 \\
\hline 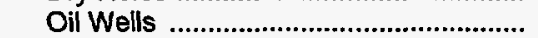 & 56.3 & 61.7 & 38.2 & 19.7 & 47.9 & 42.0 & 66.6 \\
\hline 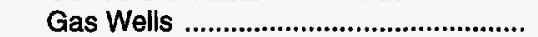 & 38.3 & 48.3 & 54.0 & 29.6 & 46.8 & 105.1 & 74.0 \\
\hline $\begin{array}{l}\text { Total Exploratory Wells } \\
\text { Development Wells }\end{array}$ & 208.5 & 214.9 & 193.5 & 114.4 & 166.4 & 258.3 & 248.1 \\
\hline 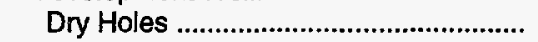 & 34.7 & 47.2 & 32.3 & 29.3 & 47.4 & 59.6 & 42.7 \\
\hline Oil Wells ................................................. & 168.3 & 225.7 & 169.6 & 211.1 & 334.6 & 174.2 & 569.5 \\
\hline 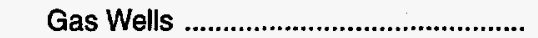 & 39.8 & 97.1 & 97.0 & 39.4 & 292.9 & 416.6 & 189.6 \\
\hline Total Development Wells ................... & 242.8 & 370.0 & 298.9 & 279.8 & 674.9 & 650.4 & 801.8 \\
\hline $\begin{array}{l}\text { Net In-Progress Wells at Year End ......... } \\
\text { Net Producing Wells }\end{array}$ & 126.3 & 63.9 & 29.3 & 31.7 & 65.3 & 57.6 & 43.1 \\
\hline 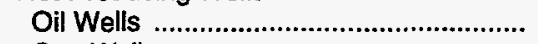 & $15,880.1$ & $15,044.9$ & $13,996.6$ & $12,597.5$ & $11,704.3$ & $11,268.5$ & $9,793.9$ \\
\hline 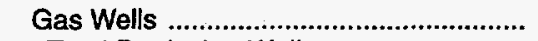 & $7,162.6$ & $6,635.8$ & $6,094.0$ & $5,927.2$ & $5,740.2$ & $5,953.3$ & $5,998.6$ \\
\hline Total Producing Wells .......................... & $23,042.7$ & $21,680.7$ & $20,090.6$ & $18,524.7$ & $17,444.5$ & $17,221.8$ & $15,792.5$ \\
\hline \multicolumn{8}{|l|}{$\begin{array}{l}\text { Europe and Former Soviet Union } 1 \\
\text { Net Wells Completed During Year } \\
\text { Exploratory Wells }\end{array}$} \\
\hline 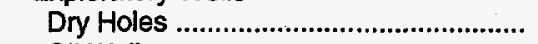 & 75.1 & 74.9 & 77.6 & 47.4 & 33.4 & 33.7 & 42.1 \\
\hline Oil Wells & 13.7 & 16.1 & 8.2 & 16.2 & 11.8 & 13.3 & 21.4 \\
\hline 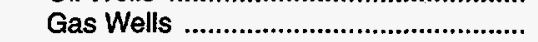 & 14.9 & 15.9 & 15.0 & 11.8 & 14.6 & 11.2 & 10.6 \\
\hline \multicolumn{8}{|l|}{ Development Wells } \\
\hline 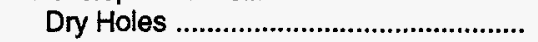 & 4.9 & 3.7 & 5.4 & 2.6 & 3.6 & 1.5 & 2.2 \\
\hline 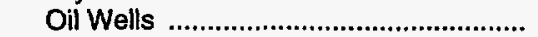 & 52.3 & 54.4 & 52.0 & 38.2 & 59.9 & 60.4 & 72.4 \\
\hline 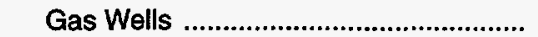 & 27.1 & 22.5 & 26.5 & 25.8 & 28.8 & 24.5 & 29.0 \\
\hline Total Development Wells .................... & 84.3 & 80.6 & 83.9 & 66.6 & 92.3 & 86.4 & 103.6 \\
\hline $\begin{array}{l}\text { Net In-Progress Wells at Year End ......... } \\
\text { Net Producing Wells }\end{array}$ & 65.6 & 78.4 & 77.0 & 70.5 & 76.3 & 74.5 & 73.0 \\
\hline Oil Wells & $\begin{array}{r}1,436.8 \\
621.7\end{array}$ & $\begin{array}{r}1,475.8 \\
643.6\end{array}$ & $\begin{array}{r}1,462.0 \\
645.4\end{array}$ & $\begin{array}{r}1,459.3 \\
647.5\end{array}$ & $\begin{array}{r}1,479.3 \\
687.0\end{array}$ & $\begin{array}{r}1,430.2 \\
720.7\end{array}$ & $\begin{array}{r}1,359.4 \\
741.9\end{array}$ \\
\hline Total Producing Wells .......................... & $2,058.5$ & $2,119.4$ & $2,107.4$ & $2,106.8$ & $2,166.3$ & $2,150.9$ & $2,101.3$ \\
\hline \multicolumn{8}{|l|}{$\begin{array}{l}\text { Africa and Middle East } \\
\text { Net Wells Completed During Year } \\
\text { Exploratory Wells }\end{array}$} \\
\hline 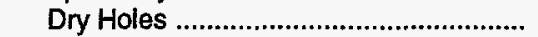 & 37.8 & 51.4 & 54.5 & 65.3 & 37.9 & 32.0 & 28.4 \\
\hline 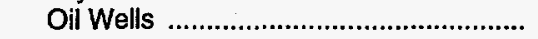 & 14.5 & W & $W$ & $W$ & $W$ & W & W \\
\hline 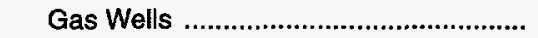 & 1.7 & W & W & W & W & W & W \\
\hline $\begin{array}{l}\text { Total Exploratory Wells } \ldots . . . . . . . . . . . . . . . . . \\
\text { Development Wells }\end{array}$ & 54.0 & 67.5 & 73.9 & 84.8 & 52.8 & 47.9 & 42.8 \\
\hline 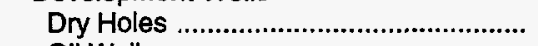 & W & 6.6 & W & W & W & W & $W$ \\
\hline 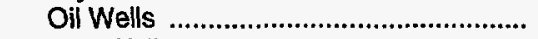 & 85.6 & 77.5 & 82.7 & 91.1 & 72.2 & 105.7 & 109.7 \\
\hline 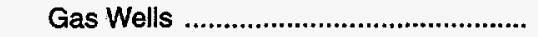 & W & 2.0 & W & W & W & W & W \\
\hline Total Development Wells ................... & 93.1 & 86.1 & 94.1 & 103.5 & 81.8 & 117.7 & 119.2 \\
\hline $\begin{array}{l}\text { Net In-Progress Wells at Year End ......... } \\
\text { Net Producing Wells }\end{array}$ & 48.0 & 29.0 & 44.0 & 34.4 & 21.3 & 45.1 & 41.9 \\
\hline Oil Wells & $1,349.2$ & $1,240.7$ & $1,294.2$ & $1,374.1$ & $1,322.9$ & $1,442.2$ & $1,509.0$ \\
\hline 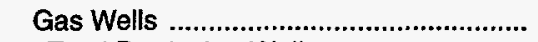 & 20.4 & 20.0 & 20.6 & 26.8 & 25.8 & 34.4 & 41.9 \\
\hline Total Producing Wells ......................... & $1,369.6$ & $1,260.7$ & $1,3+4.8$ & $1,400.9$ & $1,348.7$ & $1,476.6$ & $1,550.9$ \\
\hline
\end{tabular}

See footnotes at end of table. 
Table B36. Number of Net Wells Completed, Net In-Progress Wells, and Net Producing Wells in Foreign Areas for FRS Companies, 1989-1995 (Continued)

\begin{tabular}{|c|c|c|c|c|c|c|c|}
\hline Number of Wells & 1989 & 1990 & 1991 & 1992 & 1993 & 1994 & 1995 \\
\hline \multicolumn{8}{|l|}{$\begin{array}{l}\text { Other Eastern Hemisphere } \\
\text { Net Wells Completed During Year } \\
\text { Exploratory Wells }\end{array}$} \\
\hline 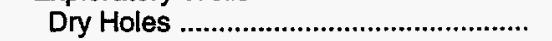 & 61.1 & 57.4 & 60.5 & 47.6 & 43.9 & 47.4 & 47.4 \\
\hline Oil Wells & 19.9 & 18.0 & 21.1 & 22.9 & 8.3 & 11.6 & 13.1 \\
\hline Gas Wells & 15.2 & 11.0 & 11.4 & 10.0 & 16.4 & 14.5 & 44.4 \\
\hline $\begin{array}{l}\text { Total Exploratory Wells } \\
\text { Development Well..................... }\end{array}$ & \multicolumn{6}{|c|}{ Development Wells } & 104.9 \\
\hline 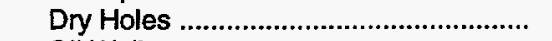 & 5.5 & 4.5 & 14.5 & 11.0 & 8.7 & 5.2 & 1.5 \\
\hline Oil Wells & 130.1 & 124.6 & 106.4 & 106.7 & 124.9 & 115.7 & 92.7 \\
\hline Gas Wells & 41.3 & 47.2 & 48.6 & 71.9 & 62.7 & 45.9 & 32.4 \\
\hline Total Development Wells ........................ & 176.9 & 176.3 & 169.5 & 189.6 & 196.3 & 166.8 & 126.6 \\
\hline $\begin{array}{l}\text { Net In-Progress Wells at Year End ......... } \\
\text { Net Producing Wells }\end{array}$ & 65.4 & 85.5 & 89.4 & 71.5 & 83.8 & 71.9 & 92.5 \\
\hline Oil Wells & $1,468.3$ & $1,632.9$ & $1,532.1$ & $1,650.2$ & $1,666.0$ & $1,714.9$ & $1,476.2$ \\
\hline 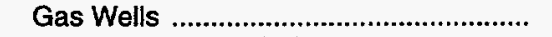 & 279.8 & 324.8 & 321.1 & 373.2 & 393.9 & 437.9 & 401.4 \\
\hline Total Producing Wells ................................ & $1,748.1$ & $1,957.7$ & $1,853.2$ & $2,023.4$ & $2,059.9$ & $2,152.8$ & $1,877.6$ \\
\hline \multirow{2}{*}{\multicolumn{8}{|c|}{$\begin{array}{l}\text { Other Western Hemisphere } \\
\text { Net Wells Completed During Year } \\
\text { Exploratory Wells }\end{array}$}} \\
\hline & & & & & & & \\
\hline 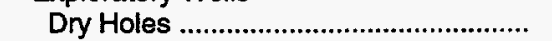 & 22.6 & 19.7 & 15.1 & 6.9 & 8.1 & 7.5 & 9.2 \\
\hline 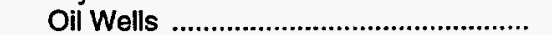 & W & W & W & W & $\mathbf{w}$ & W & $\mathbf{w}$ \\
\hline Gas Wells & W & W & W & W & W & W & $\mathbf{W}$ \\
\hline \multicolumn{7}{|l|}{ Development Wells } & 13.9 \\
\hline 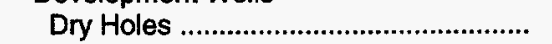 & 5.0 & w & W & w & $w$ & $w$ & W \\
\hline Oil Wells & 119.5 & 87.4 & 87.4 & 87.0 & 78.8 & 85.6 & 120.5 \\
\hline 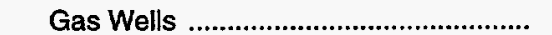 & 0.0 & W & W & W & w & W & W \\
\hline Total Development Wells .................... & 124.5 & 89.9 & 93.4 & 89.0 & 87.2 & 94.3 & 133.1 \\
\hline $\begin{array}{l}\text { Net In-Progress Wells at Year End ......... } \\
\text { Net Producing Wells }\end{array}$ & 10.3 & 15.1 & 9.6 & 7.4 & 15.6 & 14.8 & 20.2 \\
\hline 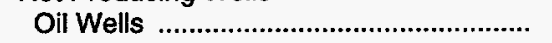 & $3,276.8$ & $3,102.0$ & $3,145.5$ & $2,938.3$ & $3,032.6$ & $2,939.6$ & $2,980.6$ \\
\hline 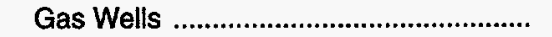 & 88.4 & 48.4 & 44.5 & 42.0 & 65.4 & 48.7 & 57.6 \\
\hline Total Producing Wells ............................... & $3,365.2$ & $3,150.4$ & $3,190.0$ & $2,980.3$ & $3,098.0$ & $2,988.3$ & $3,038.2$ \\
\hline \multicolumn{8}{|l|}{ Total Foreign } \\
\hline \multicolumn{8}{|l|}{$\begin{array}{l}\text { Net Wells Completed During Year } \\
\text { Exploratory Wells }\end{array}$} \\
\hline Exploratory Wells & & & & & & & \\
\hline 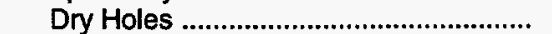 & 310.5 & 308.3 & 309.0 & 232.3 & 195.0 & 231.8 & 234.6 \\
\hline 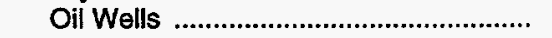 & 107.9 & 112.7 & 95.5 & 81.0 & 93.0 & 88.5 & 119.7 \\
\hline 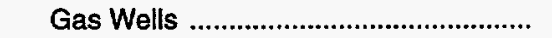 & 74.2 & 77.4 & 82.3 & 53.8 & 79.4 & 133.1 & 129.5 \\
\hline Total Exploratory Wells .......................... & 492.6 & 498.4 & 486.8 & 367.1 & 367.4 & 453.4 & 483.8 \\
\hline \multicolumn{8}{|l|}{ Development Wells } \\
\hline Dry Holes & 57.2 & 64.5 & 61.3 & 52.2 & 71.1 & 77.2 & 51.9 \\
\hline 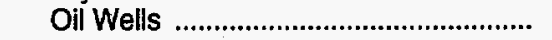 & 555.8 & 569.6 & 498.1 & 534.1 & 670.4 & 541.6 & 964.8 \\
\hline Gas Wells & 108.6 & 168.8 & 180.4 & 142.2 & 391.0 & 496.8 & 267.6 \\
\hline Total Development Wells ..................... & 721.6 & 802.9 & 739.8 & 728.5 & $1,132.5$ & $1,115.6$ & $1,284.3$ \\
\hline Net In-Progress Wells at Year End .......... & 315.6 & 271.9 & 249.3 & 215.5 & 262.3 & 263.9 & 270.7 \\
\hline \multicolumn{8}{|l|}{ Net Producing Wells } \\
\hline Oil Wells & $23,411.2$ & $22,496.3$ & $21,430.4$ & $20,019.4$ & $19,205.1$ & $18,795.4$ & $\begin{array}{r}17,119.1 \\
7 ? 414\end{array}$ \\
\hline Gas Wells & $8,172.9$ & $7,672.6$ & $7,125.6$ & $7,016.7$ & $\begin{array}{r}6,912.3 \\
26,1174\end{array}$ & $\begin{array}{r}7,195.0 \\
250904\end{array}$ & $\begin{array}{r}7,241.4 \\
24,360.5\end{array}$ \\
\hline Total Producing Wells ............................. & $31,584.1$ & $30,168.9$ & $28,556.0$ & $27,036.1$ & $26,117.4$ & $25,990.4$ & $24,360.5$ \\
\hline
\end{tabular}

1 OECD Europe combined with the former Soviet Union and Eastern Europe to avoid disclosure. Prior to 1993, only OECD Europe is included in this region.

= Data withheld to avoid disclosure.

Source: Energy Information Administration, Form EIA-28. 
Table B37. Foreign Proved Oil and Gas Reserves for FRS Companies, 1995

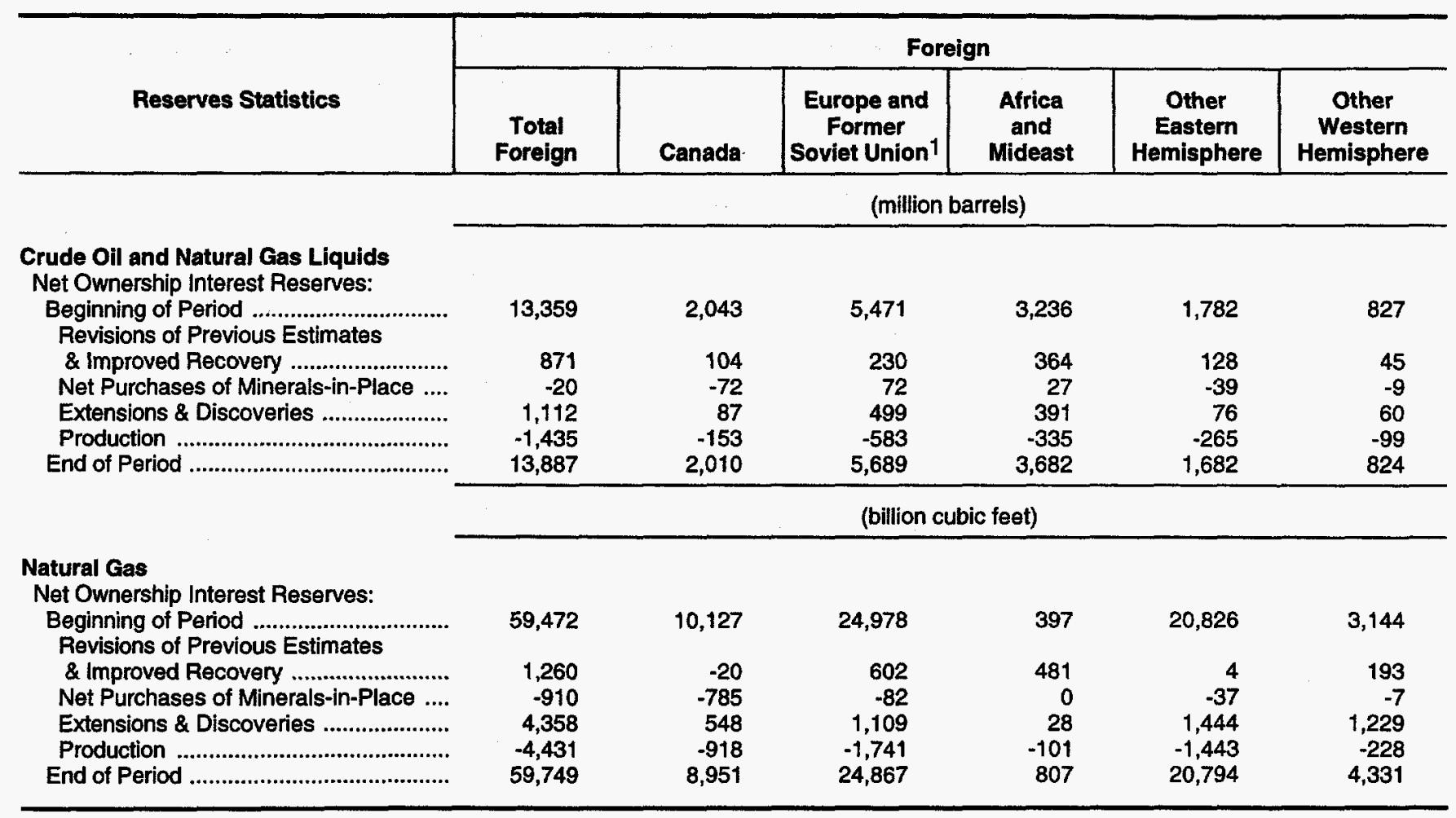

1 OECD Europe combined with the former Soviet Union and Eastern Europe to avoid disclosure. Prior to 1993, only OECD Europe is included in this region.

$W=$ Data withheld to avoid disclosure.

Source: Energy Information Administration, Form ElA-28. 
Table B38. Foreign Production (Lifting) Costs for FRS Companies, 1989-1995

(Million Dollars)

\begin{tabular}{|c|c|c|c|c|c|c|c|}
\hline Production Costs by Region & 1989 & 1990 & 1991 & 1992 & 1993 & 1994 & 1995 \\
\hline \multicolumn{8}{|l|}{ Canada } \\
\hline 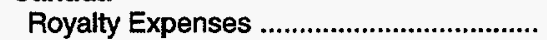 & 19 & w & W & $w$ & 19 & w & $w$ \\
\hline Taxes other than Income Taxes ............... & 94 & $w$ & $w$ & $w$ & 56 & w & $w$ \\
\hline 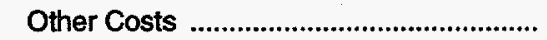 & 1,528 & 1,736 & 1,797 & 1,388 & 1,210 & 1,141 & 1,082 \\
\hline 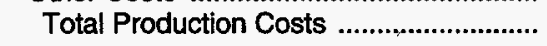 & 1,641 & 1,814 & 1,893 & 1,464 & 1,285 & 1,234 & 1,174 \\
\hline \multicolumn{8}{|l|}{ OECD Europe } \\
\hline 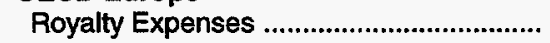 & 224 & 544 & 495 & 465 & 305 & 206 & 235 \\
\hline Taxes other than Income Taxes ............... & 100 & 270 & 229 & 257 & 214 & 274 & 262 \\
\hline Other Costs & 3,073 & 3,692 & $4, \overline{353}$ & 4,199 & 3,617 & 4,128 & 3,966 \\
\hline Total Production Costs .............................. & 3,397 & 4,506 & 5,077 & 4,921 & 4,136 & 4,608 & 4,463 \\
\hline \multicolumn{8}{|l|}{ Former Soviet Union and E. Europe } \\
\hline Royalty Expenses & 0 & 0 & 0 & 0 & 0 & 0 & 0 \\
\hline Taxes other than Income Taxes ............... & 0 & 0 & 0 & 0 & 0 & W & w \\
\hline 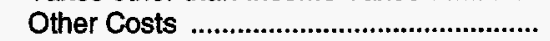 & 0 & 0 & 0 & 0 & 54 & W & W \\
\hline 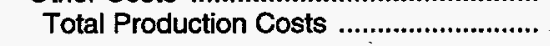 & 0 & 0 & 0 & 0 & 54 & 65 & 128 \\
\hline \multicolumn{8}{|l|}{ Africa } \\
\hline 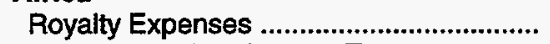 & 210 & 317 & 295 & 282 & $w$ & $\mathbf{w}$ & $w$ \\
\hline Taxes other than Income Taxes ................ & 14 & 9 & 14 & 21 & W & w & W \\
\hline Other Costs & 480 & 625 & 680 & 776 & 821 & 740 & 607 \\
\hline 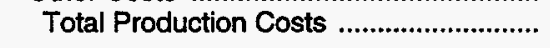 & 704 & 951 & 989 & 1,079 & 1,122 & 1,011 & 916 \\
\hline \multicolumn{8}{|l|}{ Middle East } \\
\hline 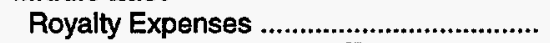 & $w$ & $w$ & $\mathbf{w}$ & 62 & w & $\mathbf{w}$ & W \\
\hline Taxes other than Income Taxes ............... & W & W & W & 292 & W & w & W \\
\hline Other Costs & 295 & 305 & 217 & 324 & 313 & 340 & 258 \\
\hline 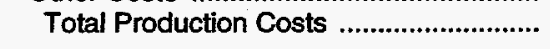 & 454 & 468 & 316 & 678 & 424 & 435 & 403 \\
\hline \multicolumn{8}{|l|}{ Other Eastern Hemisphere } \\
\hline Royalty Expenses and & & & & & & & \\
\hline Taxes other than Income Taxes .............. & 566 & 687 & 730 & 685 & 630 & 433 & 395 \\
\hline Other Costs & 972 & 1,318 & 1,420 & 1,400 & 1,173 & 1,132 & 1,107 \\
\hline Total Production Costs ............................... & 1,538 & 2,005 & 2,150 & 2,085 & 1,803 & 1,565 & 1,502 \\
\hline \multicolumn{8}{|l|}{ Other Western Hemisphere } \\
\hline Royalty Expenses and & & & & & & & \\
\hline Taxes other than Income Taxes ............... & 210 & 312 & 230 & 137 & 122 & 83 & 111 \\
\hline Other Costs & 482 & 530 & 481 & 450 & 374 & 346 & 415 \\
\hline 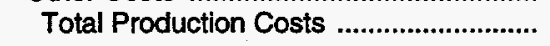 & 692 & 842 & 711 & 587 & 496 & 429 & 526 \\
\hline \multicolumn{8}{|l|}{ Total Foreign } \\
\hline 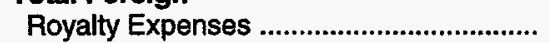 & 618 & 1,107 & 968 & 991 & 789 & 613 & 680 \\
\hline Taxes other than Income Taxes ................ & 978 & 1,273 & 1,220 & 1,286 & 969 & 843 & 870 \\
\hline Other Costs & 6,830 & 8,206 & 8,948 & 8,537 & 7,562 & 7,891 & 7,562 \\
\hline 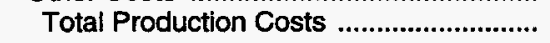 & 8,426 & 10,586 & 11,136 & 10,814 & 9,320 & 9,347 & 9,112 \\
\hline
\end{tabular}

$W=$ Data withheld to avoid disclosure.

-- Not applicable.

Source: Energy Information Administration, Form EIA-28. 
Table B39. U.S. Refining/Marketing Dispositions of Refined Products by Channel of Distribution for FRS Companies, 1989-1995

\begin{tabular}{|c|c|c|c|c|c|c|c|}
\hline U.S. Dispositions & 1989 & 1990 & 1991 & 1992 & 1993 & 1994 & 1995 \\
\hline & \multicolumn{7}{|c|}{ Values (million dollars) } \\
\hline \multicolumn{8}{|l|}{ Motor Gasoline } \\
\hline $\begin{array}{l}\text { Intersegment Sales } \\
\text { U.S. Third-Party Sales }\end{array}$ & 244 & 247 & 568 & 231 & 196 & 268 & 365 \\
\hline $\begin{array}{l}\text { Wholesale-Resellers ................................ } \\
\text { Company Operated Automotive }\end{array}$ & 26,451 & 33,255 & 28,854 & 26,641 & 24,954 & 24,923 & 27,386 \\
\hline $\begin{array}{l}\text { Outlets .................................................... } \\
\text { Company Lessee and Open }\end{array}$ & 11,308 & 14,238 & 13,059 & 12,049 & 11,018 & 9,694 & 10,088 \\
\hline $\begin{array}{l}\text { Automotive Outlets .................. } \\
\text { Other (Industrial, Commercial }\end{array}$ & 23,050 & 25,373 & 22,459 & 23,061 & 21,917 & 20,948 & 20,494 \\
\hline and Other Retail) & 4,566 & 4,576 & 4,043 & 5,713 & 5,391 & 5,199 & 7,368 \\
\hline 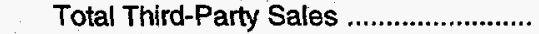 & 65,375 & 77,442 & 68,415 & 67,464 & 63,280 & 60,764 & 65,336 \\
\hline Total Motor Gasoline Sales ............................. & 65,619 & 77,689 & 68,983 & 67,695 & 63,476 & 61,032 & 65,701 \\
\hline \multicolumn{8}{|l|}{ Distillate Fuels } \\
\hline Intersegment Sales & 398 & 473 & 483 & 550 & 440 & 211 & 219 \\
\hline Third-Party Sales .............................................. & 32,277 & 40,222 & 35,052 & 33,370 & 32,624 & 30,357 & 30,201 \\
\hline Total Distillate Fuels Sales .............................. & 32,675 & 40,695 & 35,535 & 33,920 & 33,064 & 30,568 & 30,420 \\
\hline \multicolumn{8}{|l|}{ Other Refined Products } \\
\hline 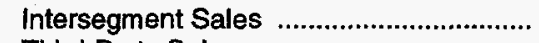 & 4,511 & 5,093 & 4,435 & 4,671 & 4,213 & 3,824 & 3,952 \\
\hline 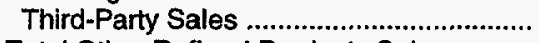 & 19,124 & 20,945 & 19,032 & 17,854 & 16,894 & 19,366 & 20,625 \\
\hline Total Other Refined Products Sales ............ & 23,635 & 26,038 & 23,467 & 22,525 & 21,107 & 23,190 & 24,577 \\
\hline \multicolumn{8}{|l|}{ Total U.S. Refined Products } \\
\hline 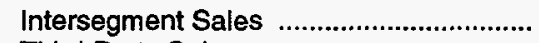 & 5,153 & 5,813 & 5,486 & 5,452 & 4,849 & 4,303 & 4,536 \\
\hline 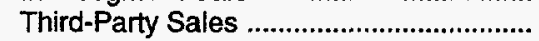 & 116,776 & 138,609 & 122,499 & 118,688 & 112,798 & 110,487 & 116,162 \\
\hline \multirow[t]{2}{*}{ Total U.S. Refined Products Sales ............. } & 121,929 & 144,422 & 127,985 & 124,140 & 117,647 & 114,790 & 120,698 \\
\hline & \multicolumn{7}{|c|}{ Volumes (million barrels) } \\
\hline \multicolumn{8}{|l|}{ Motor Gasoline } \\
\hline Intersegment Sales & 12 & 8 & 18 & 9 & 9 & 9 & 11 \\
\hline \multicolumn{8}{|l|}{ U.S. Third-Party Sales } \\
\hline $\begin{array}{l}\text { Wholesale-Resellers .................................. } \\
\text { Company Operated Automotive }\end{array}$ & 1,007 & 1,072 & 996 & 972 & 1,012 & 1,064 & 1,117 \\
\hline 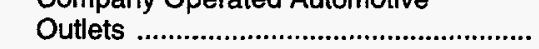 & 356 & 384 & 367 & 350 & 342 & 308 & 309 \\
\hline Company Lessee and Open & & & & & & & \\
\hline 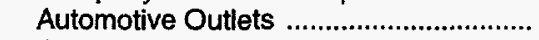 & 768 & 719 & 734 & 740 & 731 & 736 & 680 \\
\hline Other (Industrial, Commercial & & & & & & & \\
\hline and Other Retail) & 184 & 163 & 151 & 216 & 233 & 229 & 304 \\
\hline 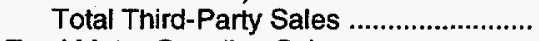 & 2,314 & 2,338 & 2,248 & 2,277 & 2,318 & 2,338 & 2,411 \\
\hline Total Motor Gasoline Sales ........................... & 2,325 & 2,346 & 2,267 & 2,286 & 2,327 & 2,347 & 2,422 \\
\hline \multicolumn{8}{|l|}{ Distillate Fuels } \\
\hline 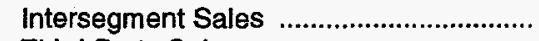 & 16 & 16 & 19 & 24 & 20 & 11 & 11 \\
\hline Third-Party Sales ............................................ & 1,345 & 1,356 & 1,328 & 1,340 & 1,380 & 1,381 & 1,363 \\
\hline Total Distillate Fuels Sales ............................. & 1,361 & 1,372 & 1,347 & 1,364 & 1,400 & 1,392 & 1,374 \\
\hline \multicolumn{8}{|l|}{ Other Refined Products } \\
\hline 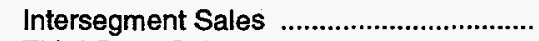 & 232 & 230 & 212 & 232 & 240 & 226 & 222 \\
\hline Third-Party Sales & 1,004 & 879 & 925 & 896 & 843 & 946 & 961 \\
\hline Total Other Refined Products Sales ........... & 1,236 & 1,108 & 1,137 & 1,128 & 1,082 & 1,172 & 1,183 \\
\hline \multicolumn{8}{|l|}{ Total U.S. Refined Products } \\
\hline 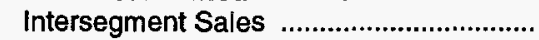 & 260 & 253 & 249 & 264 & 269 & 246 & 245 \\
\hline Third-Party Sales & 4,663 & 4,573 & 4,502 & 4,513 & 4,541 & 4,665 & 4,734 \\
\hline Total U.S. Refined Products Sales .............. & 4,923 & 4,826 & 4,751 & 4,778 & 4,810 & 4,911 & 4,979 \\
\hline
\end{tabular}

See footnote at end of table. 
Table B39. U.S. Refining/Marketing Dispositions of Refined Products by Channel of Distribution for FRS Companies, 1989-1995 (Continued)

\begin{tabular}{|c|c|c|c|c|c|c|c|}
\hline U.S. Dispositions & 1989 & 1990 & 1991 & 1992 & 1993 & 1994 & 1995 \\
\hline & \multicolumn{7}{|c|}{ Number of Automotive Outlets } \\
\hline \multicolumn{8}{|l|}{$\begin{array}{l}\text { Number of Active Automobile } \\
\text { Outlets at Year End }\end{array}$} \\
\hline 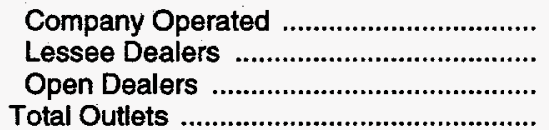 & $\begin{array}{l}10,995 \\
21,114 \\
21,475 \\
53,584\end{array}$ & $\begin{array}{l}11,177 \\
20,376 \\
19,532 \\
51,085\end{array}$ & $\begin{array}{l}10,745 \\
19,891 \\
17,969 \\
48,605\end{array}$ & $\begin{array}{r}9,935 \\
19,334 \\
17,297 \\
46,566\end{array}$ & $\begin{array}{r}9,021 \\
18,588 \\
16,088 \\
43,697\end{array}$ & $\begin{array}{r}8,755 \\
16,385 \\
15,320 \\
40,460\end{array}$ & $\begin{array}{r}8,549 \\
15,861 \\
13,950 \\
38,360\end{array}$ \\
\hline
\end{tabular}

Source: Energy Information Administration, Form EIA-28. 
Table B40. Sales of U.S. Refined Products, by Volume and Price, for FRS Companies Ranked by Total Energy Assets, 1994 and 1995

(Million Barrels and Dollars per Barrel)

\begin{tabular}{|c|c|c|c|c|c|c|c|c|}
\hline \multirow{2}{*}{ Product Distribution Channel } & \multicolumn{2}{|c|}{ All FRS } & \multicolumn{2}{|c|}{ Top Four } & \multicolumn{2}{|c|}{$\begin{array}{l}\text { Five Through } \\
\text { Twelve }\end{array}$} & \multicolumn{2}{|c|}{ All Other } \\
\hline & Volume & Price & Volume & Price & Volume & Price & Volume & Price \\
\hline \multicolumn{9}{|l|}{ Gasoline } \\
\hline 1995 & 11.4 & 32.00 & 11.3 & 32.05 & 0.1 & 20.00 & (1) & $(2)$ \\
\hline 1994 & 9.2 & 29.16 & 9.1 & 29.17 & 0.1 & 18.87 & $\left(\begin{array}{l}1 \\
0\end{array}\right)$ & $(2)$ \\
\hline $\begin{array}{l}\text { Percent Change } \\
\text { Wholesale/Resellers }\end{array}$ & 24.1 & 9.7 & 24.2 & 9.9 & -5.7 & 6.0 & $\left({ }^{2}\right)$ & $(2)$ \\
\hline 1995 & $1,117.3$ & 24.51 & 400.0 & 24.83 & 452.0 & 24.68 & 265.3 & 23.75 \\
\hline 1994 & $1,064.3$ & 23.42 & 401.5 & 23.68 & 410.8 & 23.63 & 252.0 & 22.67 \\
\hline 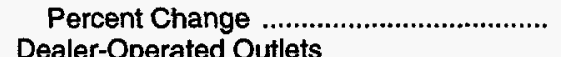 & 5.0 & 4.7 & -0.4 & 4.9 & 10.0 & 4.5 & 5.3 & 4.8 \\
\hline 1995 & 680.3 & 30.12 & 247.7 & 30.76 & 308.3 & 30.15 & 124.3 & 28.78 \\
\hline 1994 & 736.4 & 28.45 & 268.3 & 29.42 & 308.6 & 28.84 & 159.5 & 26.04 \\
\hline 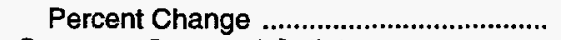 & -7.6 & 5.9 & -7.7 & 4.6 & -0.1 & 4.6 & -22.1 & 10.5 \\
\hline \multicolumn{9}{|l|}{ Company-Operated Outlets } \\
\hline 1995 & 309.4 & 32.60 & 74.8 & 34.08 & 153.1 & 31.02 & 81.6 & 34.22 \\
\hline 1994 & 308.3 & 31.44 & 87.9 & 32.68 & 149.2 & 30.51 & 71.2 & 31.86 \\
\hline 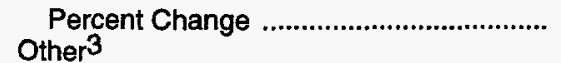 & 0.4 & 3.7 & -15.0 & 4.3 & 2.6 & 1.7 & 14.5 & 7.4 \\
\hline 1995 & 303.5 & 24.27 & 80.5 & 29.71 & 122.5 & 23.35 & 100.6 & 21.05 \\
\hline 1994 & 228.6 & 22.74 & 30.6 & 24.15 & 114.9 & 21.87 & 83.1 & 23.42 \\
\hline 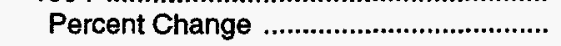 & 32.8 & 6.8 & 162.6 & 23.0 & 6.6 & 6.8 & 21.0 & -10.1 \\
\hline \multicolumn{9}{|l|}{ Total Gasoline } \\
\hline 1995 & $2,422.0$ & 27.13 & 814.3 & 28.06 & $1,035.9$ & 27.09 & 571.8 & 25.86 \\
\hline 1994 & $2,346.8$ & 26.01 & 797.5 & 26.68 & 983.4 & 26.10 & 565.9 & 24.89 \\
\hline 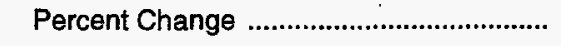 & 3.2 & 4.3 & 2.1 & 5.2 & 5.3 & 3.8 & 1.0 & 3.9 \\
\hline \multicolumn{9}{|l|}{ Distillate } \\
\hline 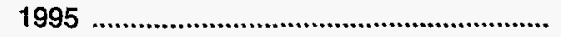 & $1,373.7$ & 22.14 & 483.2 & 22.22 & 537.8 & 22.18 & 352.7 & 21.98 \\
\hline 1994 & $1,391.7$ & 21.96 & 510.3 & 21.80 & 541.3 & 21.90 & 340.2 & 22.31 \\
\hline 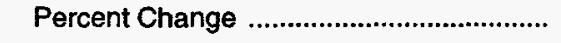 & -1.3 & 0.8 & -5.3 & 1.9 & -0.6 & 1.3 & 3.7 & -1.5 \\
\hline \multicolumn{9}{|l|}{ All Other Products } \\
\hline $1995 \ldots \ldots \ldots \ldots \ldots . . . . . . . . . .$. & $1,183.1$ & 20.77 & 315.3 & 24.44 & 422.9 & 18.42 & 445.0 & 20.41 \\
\hline 1994 & $1,172.5$ & 19.78 & 344.9 & 22.15 & 389.5 & 17.64 & 438.1 & 19.82 \\
\hline 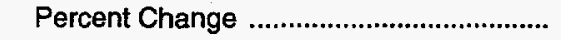 & 0.9 & 5.0 & -8.6 & 10.3 & 8.6 & 4.5 & 1.6 & 3.0 \\
\hline \multicolumn{9}{|l|}{ Total Refined Products } \\
\hline 1995 & $4,978.8$ & 24.24 & $1,612.8$ & 25.61 & $1,996.6$ & 23.93 & $1,369.5$ & 23.09 \\
\hline 1994 & $4,911.0$ & 23.37 & $1,652.6$ & 24.23 & $1,914.2$ & 23.19 & $1,344.2$ & 22.58 \\
\hline 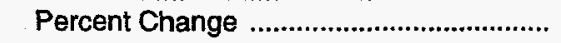 & 1.4 & 3.7 & -2.4 & 5.7 & 4.3 & 3.2 & 1.9 & 2.2 \\
\hline
\end{tabular}

1 Less than 50,000 barrels.

2 Not meaningful.

3 Includes direct sales to industrial and commercial customers and sales to unconsolidated affiliates.

Note: Sum of components may not equal total due to independent rounding.

Source: Energy Information Administration, Form ElA-28. 
Table B41. U.S. Petroleum Refining/Marketing, General Operating Expenses for FRS Companies, 1989-1995 (Billion Dollars)

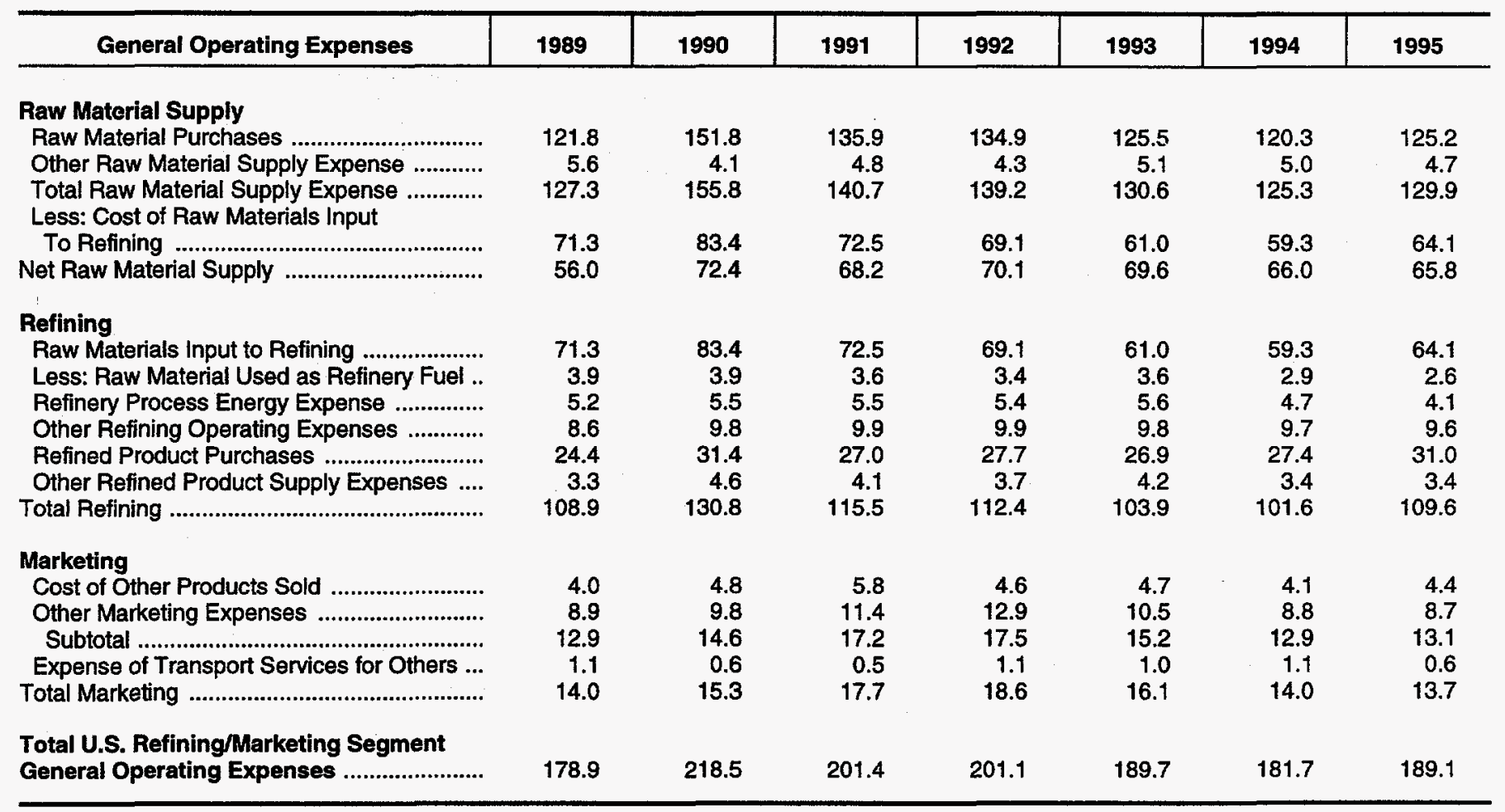

Source: Energy Information Administration, Form ElA-28. 
Table B42. U.S. Petroleum Segments Purchases and Sales of Raw Materials and Refined Products for FRS Companies, 1989-1995

\begin{tabular}{|c|c|c|c|c|c|c|c|}
\hline Purchases and Sales & 1989 & 1990 & 1991 & 1992 & 1993 & 1994 & 1995 \\
\hline & \multicolumn{7}{|c|}{ Values (million dollars) } \\
\hline \multicolumn{8}{|l|}{$\begin{array}{l}\text { Purchases } \\
\text { U.S. Refining/Marketing Segment } \\
\text { Raw Materials }\end{array}$} \\
\hline 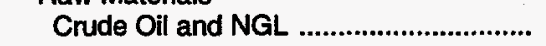 & 116,552 & 144,973 & 129,380 & 124,868 & 111,654 & 104,471 & 111,556 \\
\hline 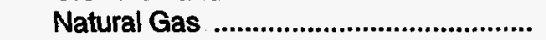 & 3,237 & 3,935 & 4,367 & 7,504 & 10,678 & 12,360 & 9,747 \\
\hline 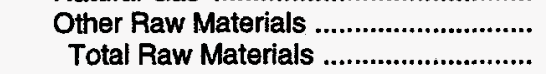 & $\begin{array}{r}1,973 \\
121,762\end{array}$ & $\begin{array}{r}2,848 \\
151,756\end{array}$ & $\begin{array}{r}2,195 \\
135,942\end{array}$ & $\begin{array}{r}2,496 \\
134,868\end{array}$ & $\begin{array}{r}3,196 \\
125,528\end{array}$ & $\begin{array}{r}3,498 \\
120,329\end{array}$ & $\begin{array}{r}3,892 \\
125,195\end{array}$ \\
\hline \multicolumn{8}{|l|}{ Refined Products } \\
\hline Motor Gasoline & 11,095 & 13,927 & 12,106 & 12,403 & 11,831 & 12,430 & 14,131 \\
\hline 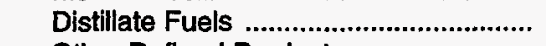 & 5,274 & 7,006 & 5,738 & 6,008 & 6,629 & 6,626 & 6,773 \\
\hline Other Refined Products ........................... & 8,016 & 10,497 & 9,136 & 9,261 & 8,467 & 8,389 & 10,114 \\
\hline 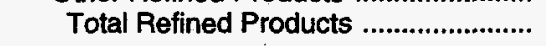 & 24,385 & 31,430 & 26,980 & 27,672 & 26,927 & 27,445 & 31,018 \\
\hline \multicolumn{8}{|l|}{ U.S. Production Segment } \\
\hline Crude Oil and NGL & 2,138 & 2,702 & 4,186 & 2,816 & 2,458 & 2,660 & 3,353 \\
\hline 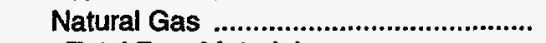 & 2,845 & 3,167 & 3,223 & 4,192 & 5,042 & 5,950 & 6,981 \\
\hline 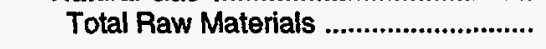 & 4,983 & 5,869 & 7,409 & 7,008 & 7,500 & 8,610 & 10,334 \\
\hline \multirow{2}{*}{\multicolumn{8}{|c|}{$\begin{array}{l}\text { Sales } \\
\text { U.S. Refining/Marketing Segment } \\
\text { Raw Materials }\end{array}$}} \\
\hline & & & & & & & \\
\hline 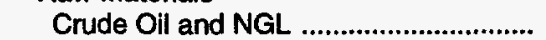 & 55,078 & 69,037 & 64,948 & 63,564 & 56,612 & 49,752 & 53,544 \\
\hline 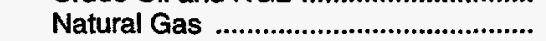 & 2,262 & 3,226 & 3,873 & 7,406 & 10,527 & 12,432 & 9,295 \\
\hline Other Raw Materials .............................. & 1,084 & 1,271 & 929 & 1,175 & 1,720 & 2,201 & 2,325 \\
\hline 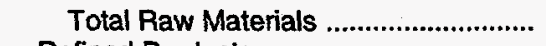 & 58,424 & 73,534 & 69,750 & 72,145 & 68,859 & 64,385 & 65,164 \\
\hline \multicolumn{8}{|l|}{ Refined Products } \\
\hline 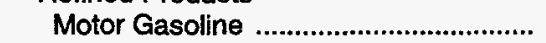 & 65,619 & 77,689 & 68,983 & 67,695 & 63,476 & 61,032 & 65,701 \\
\hline 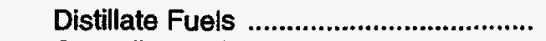 & 32,675 & 40,695 & 35,535 & 33,920 & 33,064 & 30,568 & 30,420 \\
\hline Other Refined Products ............................ & 23,635 & 26,038 & 23,467 & 22,525 & 21,107 & 23,190 & 24,577 \\
\hline Total Refined Products ......................... & 121,929 & 144,422 & 127,985 & 124,140 & 117,647 & 114,790 & 120,698 \\
\hline \multicolumn{8}{|l|}{ U.S. Production Segment } \\
\hline 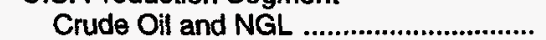 & 30,936 & 38,088 & 32,372 & 29,585 & 25,734 & 23,468 & 26,303 \\
\hline 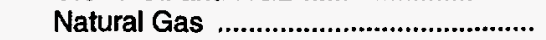 & 14,965 & 15,999 & 14,071 & 16,905 & 20,238 & 19,757 & 18,696 \\
\hline 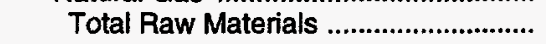 & 45,901 & 54,087 & 46,443 & 46,490 & 45,972 & 43,225 & 44,999 \\
\hline
\end{tabular}

See footnotes at end of table. 
Table B42. U.S. Petroleum Segments Purchases and Sales of Raw Materials and Refined Products for FRS Companies, 1989-1995 (Continued)

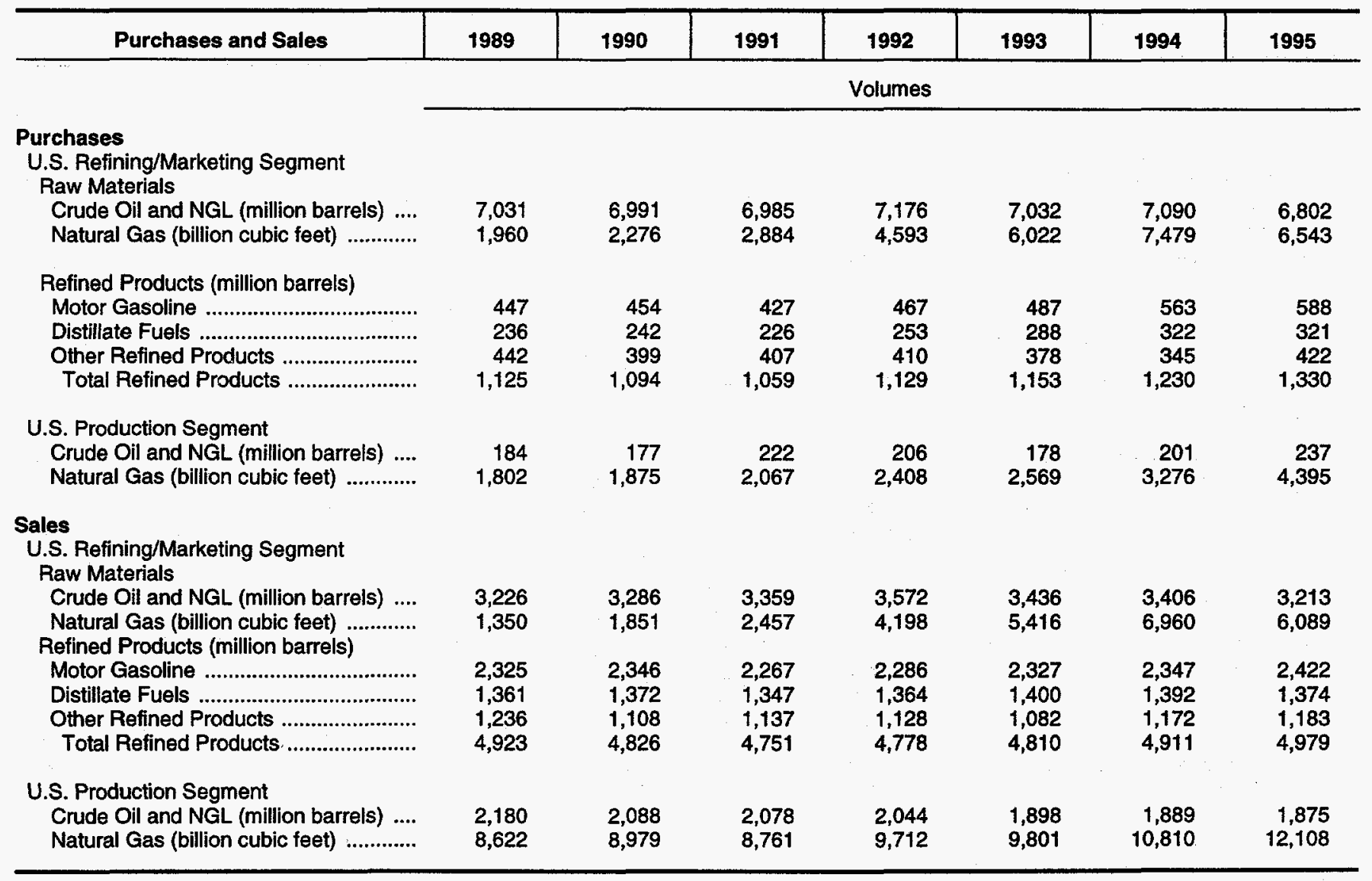

Source: Energy Information Administration, Form EIA-28. 
Table B43. U.S. and Foreign Refining/Marketing Segment, Sources and Dispositions of Crude Oil and Natural Gas Liquids for FRS Companies, 1989-1995

(Million Barrels)

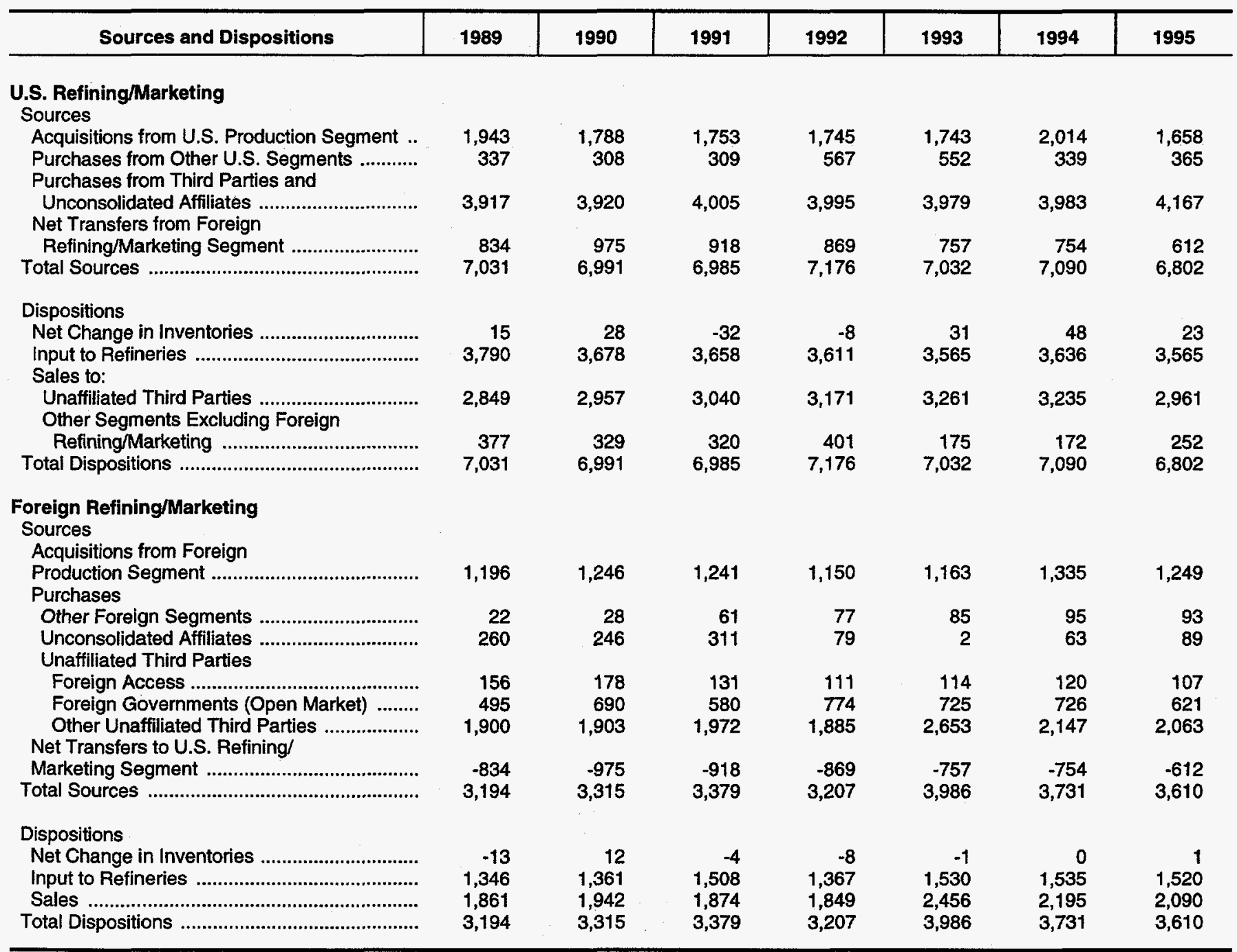

Source: Energy Information Administration, Form ElA-28. 
Table B44. U.S. and Foreign Oil Raw Materials Balance for FRS Companies Ranked by Total Energy Assets, 1993-1995

(Million Barrels)

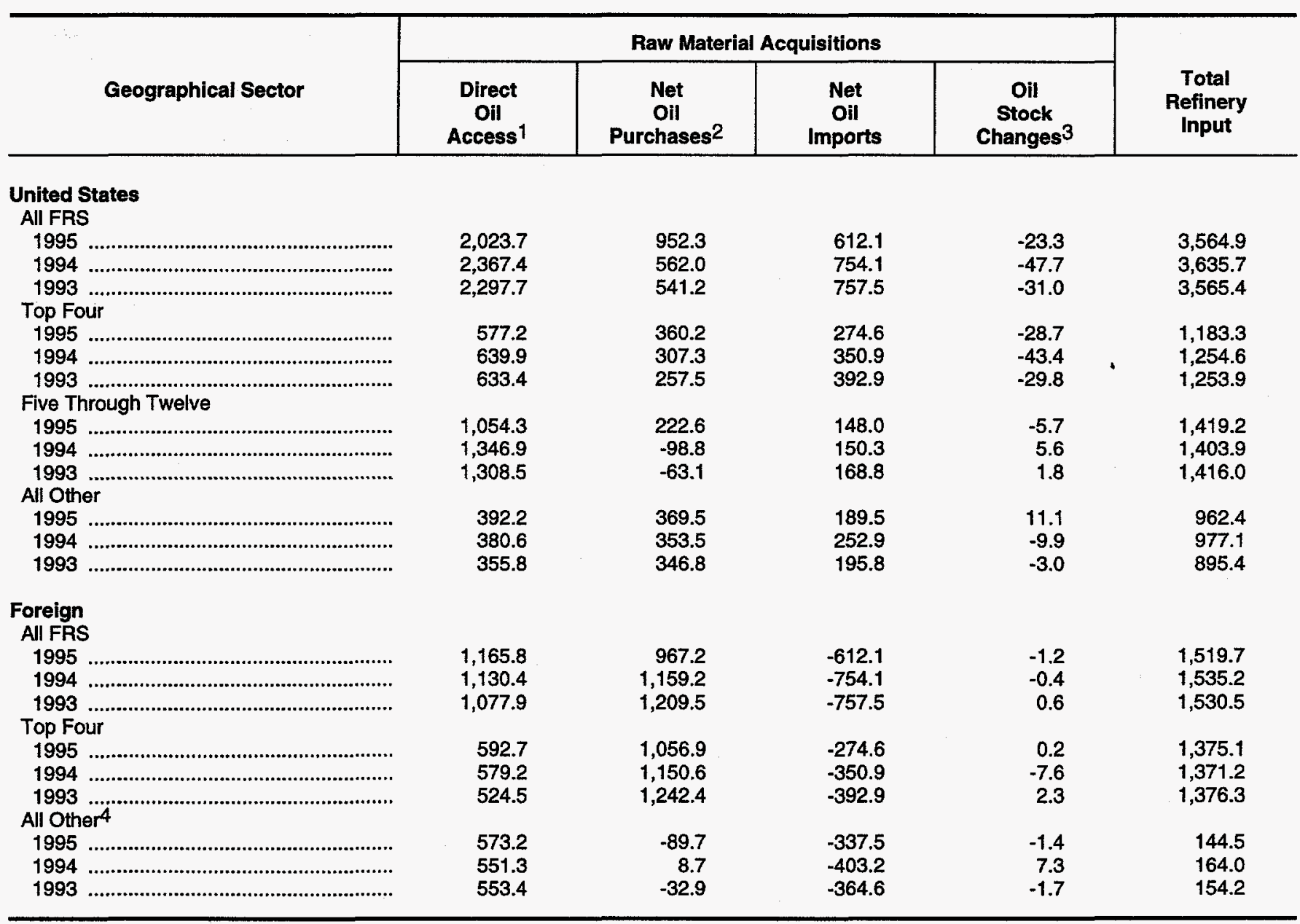

1 Ownership interest production plus purchases from other company segments and from unconsolidated affiliates of crude oil and natural gas liquids (domestic and foreign areas) plus foreign access oil (foreign area only). Foreign access represents acquisitions from foreign entities, for which reporting firms act as producers under long-term contract.

2 Purchases of crude and natural gas liquids (except imports) on the open market or from unaffiliated third parties less oil sales to unaffiliated third parties.

3 Positive number indicates stock withdrawal (addition to supply).

4 The "Five Through Twelve" and "All Other" groups combined into foreign "All Other" to prevent disclosure.

Source: Energy Information Administration, Form EIA-28. 
Table B45. U.S. Refinery Output and Refinery Capacity Statistics for FRS Companies, Ranked by Total Energy Assets, and for U.S. Industry, 1994 and 1995

(Thousand Barrels per Day)

\begin{tabular}{|c|c|c|c|c|c|c|}
\hline \multirow[b]{2}{*}{ Refined Product Statistics 1} & \multicolumn{4}{|c|}{ FRS Companies } & \multirow[b]{2}{*}{$\begin{array}{c}\text { U.S. } \\
\text { Industry }\end{array}$} & \multirow[b]{2}{*}{$\begin{array}{l}\text { FRS Percent } \\
\text { of Industry }\end{array}$} \\
\hline & $\begin{array}{c}\text { All } \\
\text { FRS }\end{array}$ & $\begin{array}{l}\text { Top } \\
\text { Four }\end{array}$ & $\begin{array}{c}\text { Five Through } \\
\text { Twelve }\end{array}$ & $\begin{array}{c}\text { All } \\
\text { Other }\end{array}$ & & \\
\hline \multicolumn{7}{|l|}{1995} \\
\hline 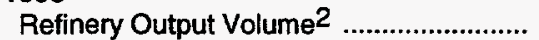 & 10,652 & 3,703 & 4,253 & 2,696 & 16,535 & 64.4 \\
\hline Percent Gasoline & 45.5 & 45.3 & 49.0 & 40.4 & 46.2 & 63.5 \\
\hline 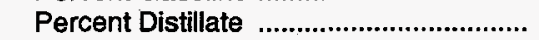 & 27.2 & 25.1 & 28.5 & 28.1 & 28.8 & 60.9 \\
\hline 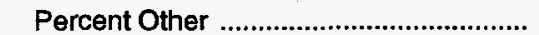 & 27.2 & 29.6 & 22.5 & 31.5 & 25.0 & 70.2 \\
\hline \multicolumn{7}{|l|}{ Refinery Capacity } \\
\hline 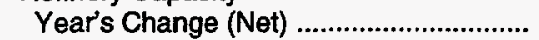 & -242 & -140 & 42 & -144 & -178 & 136.0 \\
\hline At Year End & 10,427 & 3,392 & 4,058 & 2,977 & 15,891 & 65.6 \\
\hline 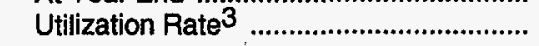 & 91.7 & 92.9 & 95.2 & 85.6 & 90.2 & $(4)$ \\
\hline \multicolumn{7}{|l|}{1994} \\
\hline Refinery Output Volume 2 & 10,812 & 3,921 & 4,246 & 2,645 & 16,341 & 66.2 \\
\hline 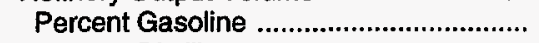 & 45.7 & 44.4 & 48.8 & 42.5 & 45.1 & 67.0 \\
\hline Percent Distillate ........................................... & 28.0 & 27.0 & 28.2 & 29.2 & 29.5 & 62.8 \\
\hline 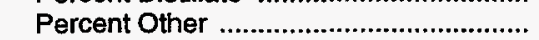 & 26.3 & 28.5 & 23.0 & 28.3 & 25.4 & 68.7 \\
\hline \multicolumn{7}{|l|}{ Refinery Capacity } \\
\hline Year's Change (Net) & -45 & -149 & -29 & 133 & 351 & -12.8 \\
\hline At Year End & 10,669 & 3,532 & 4,016 & 3,121 & 16,069 & 66.4 \\
\hline Utilization Rate ${ }^{3}$ & 91.7 & 93.6 & 94.3 & 86.2 & 90.0 & $\left({ }^{4}\right)$ \\
\hline
\end{tabular}

1 U.S. FRS and U.S. industry data include operations in Puerto Rico and the U.S. Virgin Islands.

2 For FRS companies, includes refinery output at own refineries for own account and at others' refineries for own account.

3 Defined as average daily crude runs at own refineries, for own account, and for account of others, divided by average daily crude distillation capacity.

4 Not meaningful.

Note: Sum of components may not equal total due to independent rounding.

Sources: Industry data - Refinery output and refinery capacity: Energy Information Administration, Forms EIA-820 and EIA-810; see Petroleum Supply Annual, 1994 and 1995. FRS companies data - Energy Information Administration, Form ElA-28. 
Table B46. Foreign Refinery Output and Refinery Capacity Statistics for FRS Companies, Ranked by Total Energy Assets, and for Foreign Industry, 1994 and 1995

(Thousand Barrels per Day)

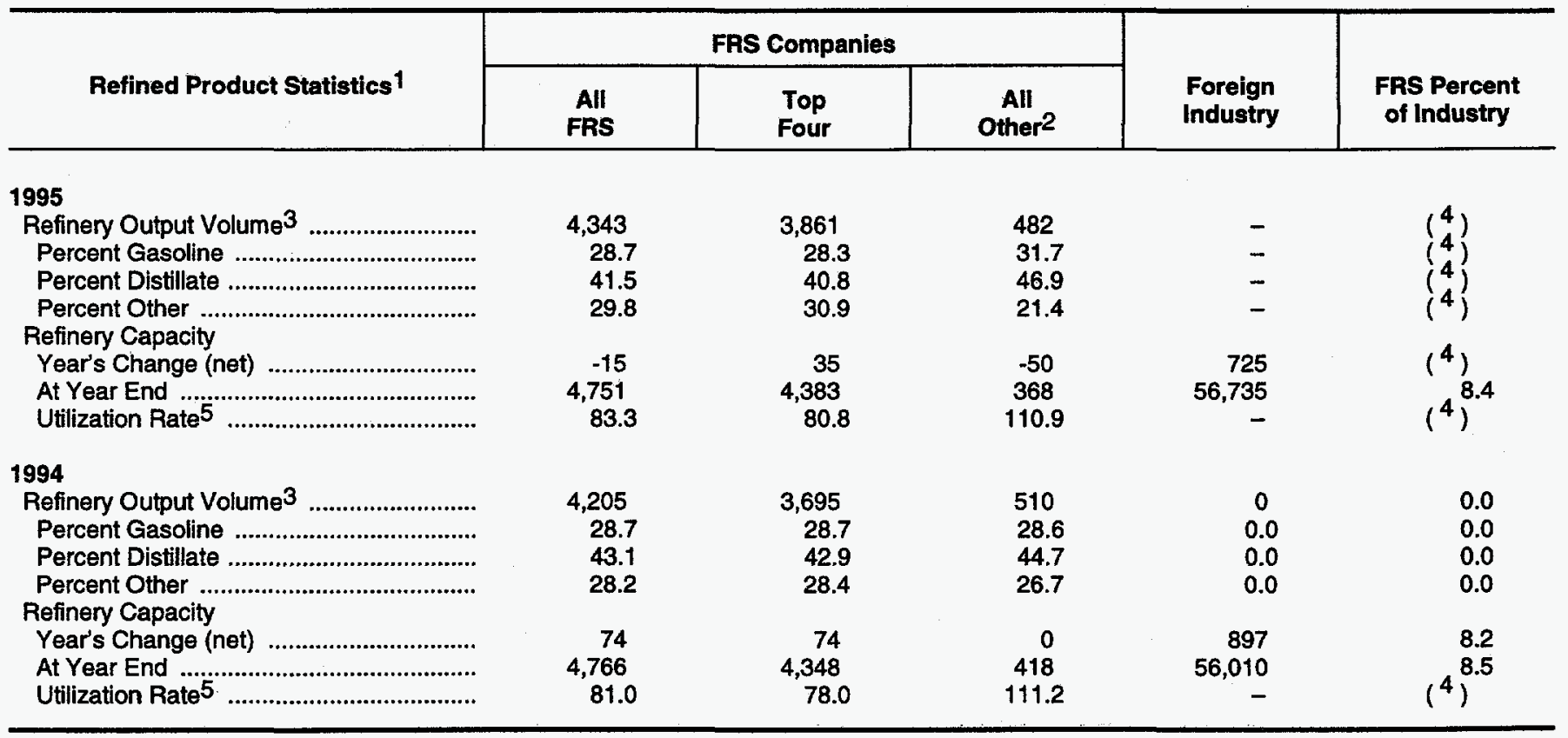

1 Foreign FRS and foreign industry data exclude operations in Puerto Rico and the U.S. Virgin Islands, as well as China.

2 "Five through Twelve" and "All Other" groups combined to avoid disclosure.

3 For FRS companies, includes refinery output at own refineries for own account and at others' refineries for own account.

4 Not meaningful.

5 Defined as average daily crude runs at own refineries, for own account, and for account of others, divided by average daily crude distillation capacity.

- = Not available.

Note: Sum of components may not equal total due to independent rounding.

Sources: Industry data - Energy Information Administration, Intemational Energy Annual, 1994 and 1995. FRS companies data - Energy Information Administration, Form ElA-28. 
Table B47. U.S. and Foreign Petroleum Refining Statistics for FRS Companies, 1989-1995

\begin{tabular}{|c|c|c|c|c|c|c|c|}
\hline Refining Statistics & 1989 & 1990 & 1991 & 1992 & 1993 & 1994 & 1995 \\
\hline & \multicolumn{7}{|c|}{ (thousand barrels per calendar day) } \\
\hline Number of Wholly Owned Refineries .... & 89 & 89 & 88 & 82 & 75 & 74 & 69 \\
\hline & \multicolumn{7}{|c|}{ (thousand barrels per calendar day) } \\
\hline 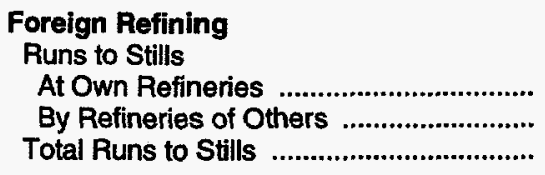 & $\begin{array}{r}3,492 \\
685 \\
4,177\end{array}$ & $\begin{array}{r}3,575 \\
717 \\
4,292\end{array}$ & $\begin{array}{r}3,667 \\
632 \\
4,299\end{array}$ & $\begin{array}{r}3,706 \\
749 \\
4,455\end{array}$ & $\begin{array}{r}3,823 \\
312 \\
4,135\end{array}$ & $\begin{array}{r}3,829 \\
304 \\
4,133\end{array}$ & $\begin{array}{r}3,962 \\
323 \\
4,285\end{array}$ \\
\hline 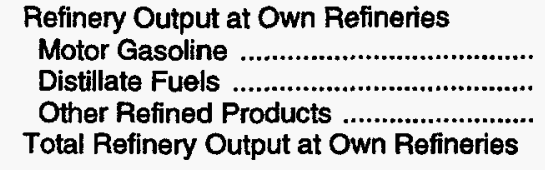 & $\begin{array}{l}1,044 \\
1,459 \\
1,196 \\
3,699\end{array}$ & $\begin{array}{l}1,084 \\
1,431 \\
1,075 \\
3,590\end{array}$ & $\begin{array}{l}1,097 \\
1,534 \\
1,009 \\
3,640\end{array}$ & $\begin{array}{l}1,098 \\
1,553 \\
1,064 \\
3,715\end{array}$ & $\begin{array}{l}1,114 \\
1,634 \\
1,148 \\
3,896\end{array}$ & $\begin{array}{l}1,122 \\
1,674 \\
1,102 \\
3,898\end{array}$ & $\begin{array}{l}1,175 \\
1,662 \\
1,183 \\
4,020\end{array}$ \\
\hline Total Refinery Output & 4,428 & 4,312 & 4,330 & 4,465 & 4,205 & 4,205 & 4,343 \\
\hline \multirow[t]{2}{*}{ Refinery Capacity at End of Year ............. } & 4,414 & 4,504 & 4,622 & 4,648 & 4,692 & 4,766 & 4,751 \\
\hline & \multicolumn{7}{|c|}{ (number of refineries) } \\
\hline Number of Wholly Owned Refineries .... & 28 & 25 & 27 & 27 & 26 & 26 & 24 \\
\hline Number of Partially Owned Refineries .. & 18 & 17 & 15 & 14 & 14 & 14 & 13 \\
\hline
\end{tabular}

Source: Energy Information Administration, Form EIA-28. 
Table B48. U.S. Refining/Marketing Revenues and Costs for FRS Companies, 1993-1995

\begin{tabular}{|c|c|c|c|c|c|c|}
\hline \multirow{2}{*}{ Revenues and Costs } & \multicolumn{3}{|c|}{ Million Dollars } & \multicolumn{3}{|c|}{ Percent of Product Revenues } \\
\hline & 1993 & 1994 & 1995 & 1993 & 1994 & 1995 \\
\hline Refined Product Revenues ...................... & $117,647.0$ & $114,790.0$ & $120,698.0$ & 100.0 & 100.0 & 100.0 \\
\hline 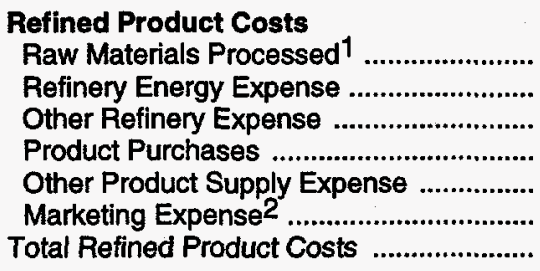 & $\begin{array}{r}58,161.0 \\
5,636.0 \\
8,889.0 \\
26,927.0 \\
4,153.0 \\
10,463.0 \\
114,229.0\end{array}$ & $\begin{array}{r}58,025.0 \\
4,702.0 \\
8,854.0 \\
27,445.0 \\
3,432.0 \\
8,822.0 \\
111,280.0\end{array}$ & $\begin{array}{r}62,142.0 \\
4,101.0 \\
8,854.0 \\
31,018.0 \\
3,432.0 \\
8,709.0 \\
118,256.0\end{array}$ & $\begin{array}{r}49.4 \\
4.8 \\
7.6 \\
22.9 \\
3.5 \\
8.9 \\
97.1\end{array}$ & $\begin{array}{r}50.5 \\
4.1 \\
7.7 \\
23.9 \\
3.0 \\
7.7 \\
96.9\end{array}$ & $\begin{array}{r}51.5 \\
3.4 \\
7.3 \\
25.7 \\
2.8 \\
7.2 \\
98.0\end{array}$ \\
\hline 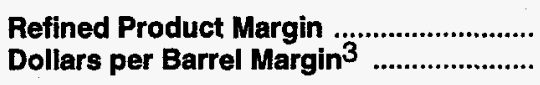 & $\begin{array}{r}3,418.0 \\
0.71\end{array}$ & $\begin{array}{r}3,510.0 \\
0.71\end{array}$ & $\begin{array}{r}2,442.0 \\
0.49\end{array}$ & $\begin{array}{l}2.9 \\
--\end{array}$ & $\begin{array}{l}3.1 \\
--\end{array}$ & $\begin{array}{l}2.0 \\
--\end{array}$ \\
\hline Other Refining/Marketing Revenues 4 ... & $10,614.0$ & $10,586.0$ & $10,449.0$ & -- & $\because$ & - \\
\hline 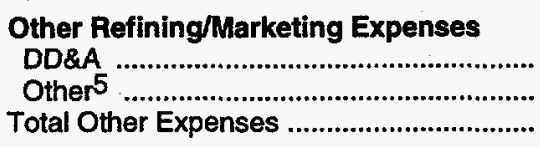 & $\begin{array}{r}3,659.0 \\
7,796.0 \\
11,455.0\end{array}$ & $\begin{array}{r}3,780.0 \\
7,454.0 \\
11,234.0\end{array}$ & $\begin{array}{r}4,732.0 \\
7,166.0 \\
11,898.0\end{array}$ & $\begin{array}{l}-- \\
-- \\
-\end{array}$ & $\begin{array}{l}-- \\
-- \\
-\end{array}$ & $\begin{array}{l}- \\
- \\
-\end{array}$ \\
\hline Refining/Marketing Operating Income .. & $2,577.0$ & $2,862.0$ & 993.0 & - & -- & - \\
\hline Miscellaneous Revenue \& Expense 6 .... & 207.0 & 289.0 & -107.0 & - & 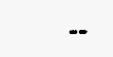 & - \\
\hline 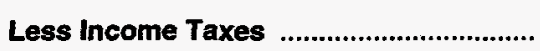 & $1,099.0$ & $1,306.0$ & 371.0 & -. & -. & - \\
\hline Refining/Marketing Net Income ............... & $1,685.0$ & $1,845.0$ & 508.0 & -- & -. & - \\
\hline
\end{tabular}

1 Represents reported cost of raw materials processed at refineries, less any profit from raw material trades or exchanges by refining/marketing.

2 Excludes cost of marketing tires, batteries, and accessories (TBA).

3 Dollars per barrel of refined product sold.

4 Includes revenues from transportation services supplied (non-federally regulated), TBA sales, and miscellaneous.

5 includes general and administrative expenses, research and development costs, costs of transportation services supplied to others not included in raw material costs, and expenses for TBA.

6 Includes other revenue and expense items, extraordinary items, and cumulative effect of accounting changes.

- = Not applicable.

Source: Energy Information Administration, Form EIA-28. 
Table B49. Sources of U.S. Bituminous Coal and Lignite Production, by Region and Mining Method, for FRS Companies and U.S. Industry, 1995, and Percent Change From 1994

\begin{tabular}{|c|c|c|c|c|c|c|}
\hline \multirow{2}{*}{ Production } & \multirow[b]{2}{*}{ Total } & \multicolumn{3}{|c|}{ Region } & \multicolumn{2}{|c|}{ Mining Method } \\
\hline & & East & Midwest & West & Underground & Surface \\
\hline \multirow{3}{*}{ 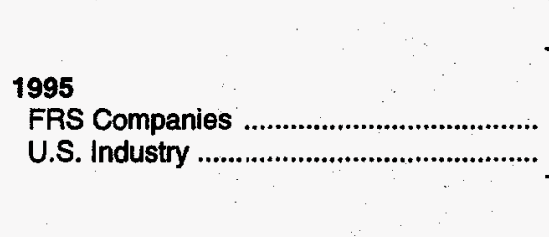 } & \multicolumn{6}{|c|}{ (million tons) } \\
\hline & $\begin{array}{r}165.4 \\
1,028.3\end{array}$ & $\begin{array}{r}45.6 \\
430.2\end{array}$ & $\begin{array}{r}17.2 \\
109.4\end{array}$ & $\begin{array}{l}102.6 \\
488.7\end{array}$ & $\begin{array}{r}62.5 \\
395.8\end{array}$ & $\begin{array}{l}102.9 \\
632.5\end{array}$ \\
\hline & \multicolumn{6}{|c|}{ (percent) } \\
\hline 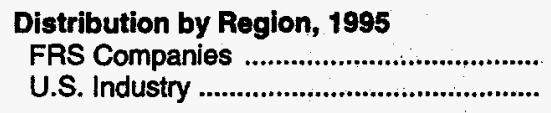 & $\begin{array}{l}100.0 \\
100.0\end{array}$ & $\begin{array}{l}27.6 \\
41.8\end{array}$ & $\begin{array}{l}10.4 \\
10.6\end{array}$ & $\begin{array}{l}62.0 \\
47.5\end{array}$ & $\overline{-}$ & $\ddot{--}$ \\
\hline 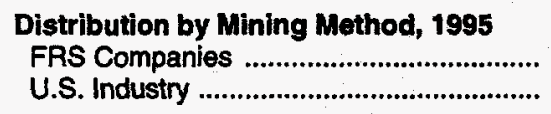 & $\begin{array}{l}100.0 \\
100.0\end{array}$ & $\ddot{--}$ & -- & - & $\begin{array}{l}37.8 \\
38.5\end{array}$ & $\begin{array}{l}62.2 \\
61.5\end{array}$ \\
\hline $\begin{array}{l}\text { FRS Companies as a Percent } \\
\text { of U.S. Industry }\end{array}$ & 16.1 & 10.6 & 15.7 & 21.0 & 15.8 & 16.3 \\
\hline $\begin{array}{l}\text { Change from } 1994 \\
\text { FRS Companies } \\
\text { U.S. Industry Total }\end{array}$ & $\begin{array}{l}-8.0 \\
-0.1\end{array}$ & $\begin{array}{l}-1.2 \\
-2.4\end{array}$ & $\begin{array}{r}8.4 \\
-9.5\end{array}$ & $\begin{array}{r}-12.8 \\
4.6\end{array}$ & $\begin{array}{r}6.7 \\
-0.8\end{array}$ & $\begin{array}{r}-15.1 \\
0.4\end{array}$ \\
\hline
\end{tabular}

-- Not applicable.

Sources: Industry data - Energy Information Administration Form ElA-7A, see Coal Industry Annual 1995 (October 1996). FRS companies data - Energy Information Administration, Form ElA-28. 
Table B50. U.S. Coal Reserves Balance for FRS Companies, 1989-1995 (Million Tons)

\begin{tabular}{|c|c|c|c|c|c|c|c|}
\hline 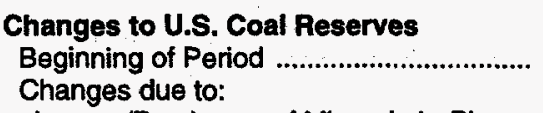 & 51,710 & 49,200 & 44,949 & 39,026 & 18,593 & 16,142 & 13,395 \\
\hline 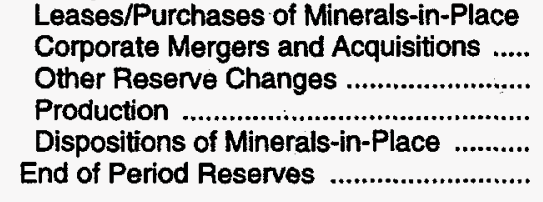 & $\begin{array}{r}417 \\
W \\
W \\
-287 \\
-793 \\
49,200\end{array}$ & $\begin{array}{r}654 \\
W \\
W \\
-282 \\
-4,002 \\
44,948\end{array}$ & $\begin{array}{r}-107 \\
W \\
W \\
-290 \\
-7,824 \\
38,219\end{array}$ & $\begin{array}{r}571 \\
W \\
W \\
-252 \\
-18,576 \\
20,787\end{array}$ & $\begin{array}{r}145 \\
0 \\
-325 \\
-197 \\
-2,074 \\
16,142\end{array}$ & $\begin{array}{r}W \\
W \\
-61 \\
-180 \\
-2,591 \\
13,381\end{array}$ & $\begin{array}{r}W \\
W \\
-699 \\
-165 \\
-2,128 \\
10,493\end{array}$ \\
\hline $\begin{array}{l}\text { Weighted Average Annual } \\
\text { Production Capacity }\end{array}$ & 322 & 320 & 327 & 291 & 236 & 201 & 184 \\
\hline
\end{tabular}

$W=$ Data withheld to avoid disclosure.

Source: Energy Information Administration, Form EIA-28. 
Table B51. U.S. Coal Reserves (End of Year) and Production Statistics for FRS Companies, 1989-1995 (Million Tons)

\begin{tabular}{|c|c|c|c|c|c|c|}
\hline \multirow{2}{*}{ Reserves and Production Statistics } & \multirow{2}{*}{$\begin{array}{l}\text { U.S. } \\
\text { Total }\end{array}$} & \multicolumn{3}{|c|}{ Region } & \multicolumn{2}{|c|}{ Mining Method } \\
\hline & & East & Midwest & West & Underground & Surface \\
\hline \multicolumn{7}{|l|}{1989} \\
\hline $\begin{array}{l}\text { U.S. Coal Reserves } \\
\text { U.S. Coal Production }\end{array}$ & $\begin{array}{r}49,200.2 \\
286.9\end{array}$ & $\begin{array}{r}11,462.1 \\
114.0\end{array}$ & $\begin{array}{r}7,324.2 \\
37.7\end{array}$ & $\begin{array}{r}30,413.9 \\
135.1\end{array}$ & $\begin{array}{r}15,783.7 \\
123.9\end{array}$ & $\begin{array}{r}33,416.4 \\
163.0\end{array}$ \\
\hline \multicolumn{7}{|l|}{1990} \\
\hline 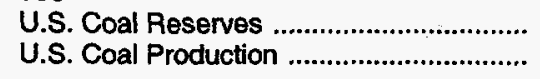 & $\begin{array}{r}44,948.5 \\
282.0\end{array}$ & $\begin{array}{r}8,864.7 \\
118.8\end{array}$ & $\begin{array}{r}6,812.0 \\
25.5\end{array}$ & $\begin{array}{r}29,271.9 \\
137.8\end{array}$ & $\begin{array}{r}14,865.6 \\
119.4\end{array}$ & $\begin{array}{r}30,082.9 \\
162.7\end{array}$ \\
\hline \multicolumn{7}{|l|}{1991} \\
\hline 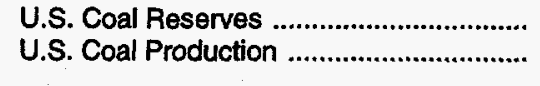 & $\begin{array}{r}38,218.9 \\
289.6\end{array}$ & $\begin{array}{r}4,802.1 \\
114.1\end{array}$ & $\begin{array}{r}5,653.1 \\
26.2\end{array}$ & $\begin{array}{r}27,763.7 \\
149.4\end{array}$ & $\begin{array}{r}10,136.4 \\
122.8\end{array}$ & $\begin{array}{r}28,082.5 \\
166.8\end{array}$ \\
\hline \multicolumn{7}{|l|}{1992} \\
\hline 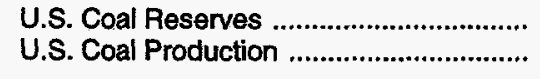 & $\begin{array}{r}20,787.2 \\
251.9\end{array}$ & $\begin{array}{r}4,190.0 \\
75.4\end{array}$ & $\begin{array}{r}4,733.3 \\
22.8\end{array}$ & $\begin{array}{r}11,863.9 \\
153.7\end{array}$ & $\begin{array}{r}8,127.0 \\
83.8\end{array}$ & $\begin{array}{r}12,660.3 \\
168.1\end{array}$ \\
\hline \multicolumn{7}{|l|}{1993} \\
\hline $\begin{array}{l}\text { U.S. Coal Reserves } \\
\text { U.S. Coal Production }\end{array}$ & $\begin{array}{r}16,142.0 \\
197.3\end{array}$ & $\begin{array}{r}2,946.0 \\
40.7\end{array}$ & $\begin{array}{r}3,673.4 \\
13.5\end{array}$ & $\begin{array}{r}9,522.6 \\
143.0\end{array}$ & $\begin{array}{r}6,068.1 \\
52.8\end{array}$ & $\begin{array}{r}10,074.0 \\
144.5\end{array}$ \\
\hline 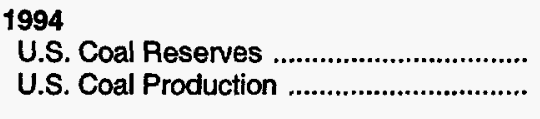 & $\begin{array}{r}13,381.3 \\
179.7\end{array}$ & $\begin{array}{r}2,833.2 \\
46.2\end{array}$ & $\begin{array}{r}3,212.5 \\
15.9\end{array}$ & $\begin{array}{r}7,335.7 \\
117.7\end{array}$ & $\begin{array}{r}5,479.1 \\
58.5\end{array}$ & $\begin{array}{r}7,902.2 \\
121.2\end{array}$ \\
\hline 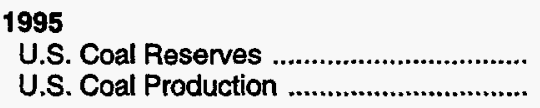 & $\begin{array}{r}10,493.2 \\
165.4\end{array}$ & $\begin{array}{r}2,763.1 \\
45.6\end{array}$ & $\begin{array}{r}3,206.0 \\
17.2\end{array}$ & $\begin{array}{r}4,524.1 \\
102.6\end{array}$ & $\begin{array}{r}5,336.9 \\
62.5\end{array}$ & $\begin{array}{r}5,156.3 \\
102.9\end{array}$ \\
\hline
\end{tabular}

Source: Energy Information Administration, Form EIA-28. 
Table B52. Research and Development Expenditures for FRS Companies, 1989-1995

(Million Dollars)

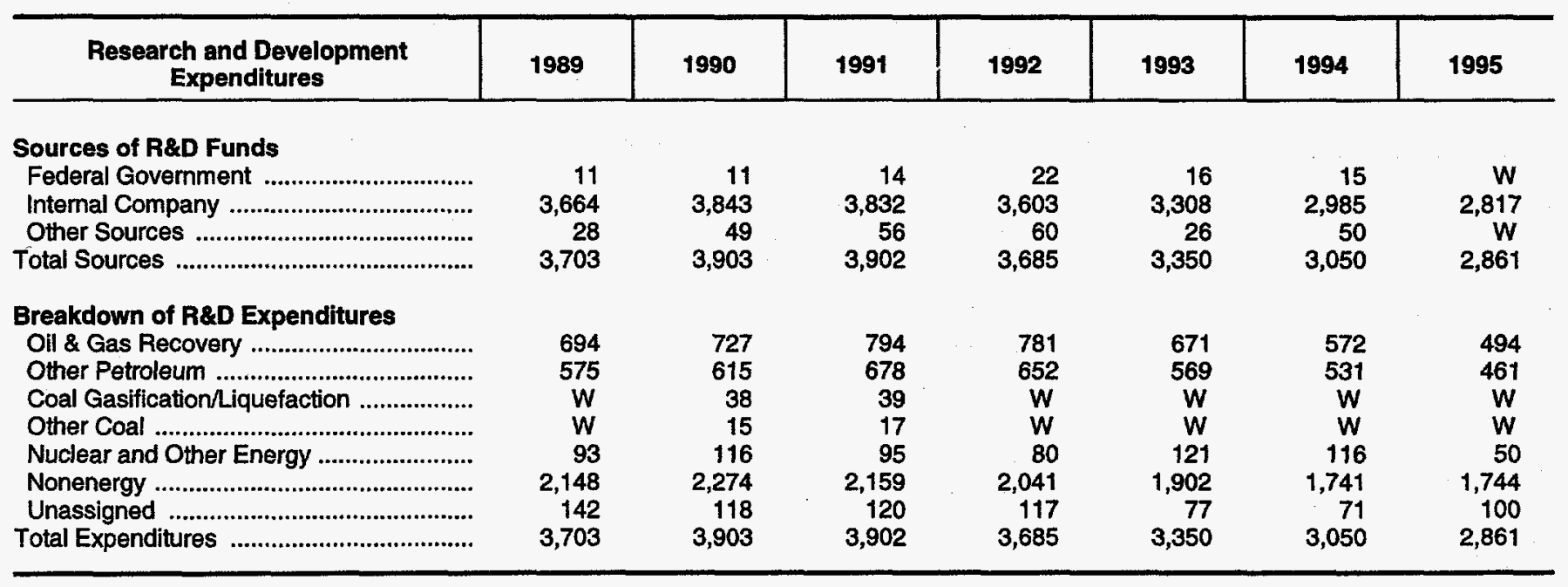

$W=$ Data withheld to avoid disclosure.

Source: Energy Information Administration, Form EIA-28. 

Appendix C

Completed Foreign Direct Investment

Transactions, 1994 



\section{Appendix C}

\section{Completed Foreign Direct Investment Transactions}

Table C1. Completed Transactions by Size in the Petroleum Industry from January 1994 Through December 1994-Acquisitions and Divestitures

\begin{tabular}{|c|c|c|c|c|c|c|}
\hline $\begin{array}{l}\text { Acquiring } \\
\text { Company }\end{array}$ & $\begin{array}{c}\text { Acquiring } \\
\text { Company Activity }\end{array}$ & Affected Company & $\begin{array}{c}\text { Affected Company } \\
\text { Activity }\end{array}$ & $\begin{array}{c}\text { Type of } \\
\text { Transaction }\end{array}$ & $\begin{array}{c}\text { Size of } \\
\text { Transaction } \\
\text { (million dollars) }\end{array}$ & $\begin{array}{c}\text { Date of } \\
\text { Transaction }\end{array}$ \\
\hline & & \multicolumn{3}{|c|}{ Acquisitions } & & \\
\hline $\begin{array}{l}\text { Nova Corp. } \\
\text { (Canada) }\end{array}$ & $\begin{array}{l}\text { Petrochemicals, } \\
\text { gas production and } \\
\text { transmission }\end{array}$ & $\begin{array}{l}\text { Natural Gas } \\
\text { Clearinghouse }\end{array}$ & $\begin{array}{l}\text { Natural gas } \\
\text { marketing }\end{array}$ & $\begin{array}{l}\text { Equity } \\
\text { acquisition }\end{array}$ & 170.0 & January \\
\hline $\begin{array}{l}\text { Bridge Oil Ltd. } \\
\text { (Australia) } \\
\text { Bridge Oil Inc. } \\
\text { (USA) }\end{array}$ & $\begin{array}{l}\text { Oil and gas } \\
\text { exploration and } \\
\text { production }\end{array}$ & $\begin{array}{l}\text { Santa Fe Energy } \\
\text { Resources Inc. }\end{array}$ & $\begin{array}{l}\text { Oil and gas } \\
\text { exploration and } \\
\text { production }\end{array}$ & $\begin{array}{l}\text { Property } \\
\text { acquisition }\end{array}$ & 48.0 & April \\
\hline $\begin{array}{l}\text { Fletcher } \\
\text { Challenge Ltd. } \\
\text { (Canada) }\end{array}$ & $\begin{array}{l}\text { Lumber, pulp, } \\
\text { building supplies, oil } \\
\text { and gas production }\end{array}$ & $\begin{array}{l}\text { Energy Develop- } \\
\text { ment investments }\end{array}$ & NA & $\begin{array}{l}\text { Property } \\
\text { acquisition }\end{array}$ & 45.0 & September \\
\hline $\begin{array}{l}\text { Cairn Energy plc. } \\
\text { (United Kingdom) } \\
\text { Cairn Energy USA } \\
\text { Inc. }\end{array}$ & $\begin{array}{l}\text { Oil and gas } \\
\text { exploration and } \\
\text { production }\end{array}$ & $\begin{array}{l}\text { Smith Offshore } \\
\text { Exploration Co. }\end{array}$ & $\begin{array}{l}\text { Oil and gas } \\
\text { exploration and } \\
\text { production }\end{array}$ & $\begin{array}{l}\text { Asset } \\
\text { acquisition }\end{array}$ & 33.7 & October \\
\hline $\begin{array}{l}\text { Interkohie } \\
\text { (Germany) } \\
\text { Penn Virginia }\end{array}$ & $\begin{array}{l}\text { Mineral rights } \\
\text { ownership and } \\
\text { leasing, coal, oil } \\
\text { and gas exploration } \\
\text { and production }\end{array}$ & $\begin{array}{l}\text { CD\&G } \\
\text { Development Corp. }\end{array}$ & NA & $\begin{array}{l}\text { Property } \\
\text { acquisition }\end{array}$ & 7.1 & May \\
\hline $\begin{array}{l}\text { Aran Energy } \\
\text { plc. } \\
\text { (United } \\
\text { Kingdom) Aran } \\
\text { Energy USA Inc. }\end{array}$ & $\begin{array}{l}\text { Oil and gas } \\
\text { exploration and } \\
\text { production }\end{array}$ & $\begin{array}{l}\text { Trust Company } \\
\text { of the West }\end{array}$ & $\begin{array}{l}\text { Asset } \\
\text { management } \\
\text { company }\end{array}$ & $\begin{array}{l}\text { Property } \\
\text { acquisition }\end{array}$ & 6.9 & March \\
\hline $\begin{array}{l}\text { Forcenergy } \\
\text { (Sweden) }\end{array}$ & $\begin{array}{l}\text { Oil and gas } \\
\text { exploration and } \\
\text { production }\end{array}$ & NA & NA & $\begin{array}{l}\text { Property } \\
\text { acquisition }\end{array}$ & 5.9 & November \\
\hline $\begin{array}{l}\text { Barntex Inc. } \\
\text { (United } \\
\text { Kingdom) } \\
\text { Bellwether } \\
\text { Exploration Co. }\end{array}$ & $\begin{array}{l}\text { Oil and gas } \\
\text { exploration and } \\
\text { production }\end{array}$ & $\begin{array}{l}\text { Odyssey } \\
\text { Partners Ltd. }\end{array}$ & $\begin{array}{l}\text { Oil and gas } \\
\text { exploration and } \\
\text { production }\end{array}$ & Merger & 5.5 & August \\
\hline
\end{tabular}


Table C1. Completed Transactions by Size in the Petroleum industry from January 1994 Through December 1994-Acquisitions and Divestitures (Continued)

\begin{tabular}{|c|c|c|c|c|c|c|}
\hline $\begin{array}{l}\text { Acquiring } \\
\text { Company }\end{array}$ & $\begin{array}{c}\text { Acquiring } \\
\text { Company Activity }\end{array}$ & Affected Company & $\begin{array}{c}\text { Affected Company } \\
\text { Activity }\end{array}$ & $\begin{array}{c}\text { Type of } \\
\text { Transaction }\end{array}$ & $\begin{array}{c}\text { Size of } \\
\text { Transaction } \\
\text { (million dollars) }\end{array}$ & $\begin{array}{c}\text { Date of } \\
\text { Transaction }\end{array}$ \\
\hline & & \multicolumn{3}{|c|}{ Acquisitions (Continued) } & & \\
\hline $\begin{array}{l}\text { Forcenergy } \\
\text { (Sweden) }\end{array}$ & $\begin{array}{l}\text { Oil and gas } \\
\text { exploration and } \\
\text { production }\end{array}$ & NA & NA & $\begin{array}{l}\text { Property } \\
\text { acquisition }\end{array}$ & 5.4 & February \\
\hline $\begin{array}{l}\text { Capco } \\
\text { Resources } \\
\text { (Canada) } \\
\text { Saba Petroleum } \\
\text { Co. }\end{array}$ & $\begin{array}{l}\text { Oil and gas } \\
\text { exploration and } \\
\text { production }\end{array}$ & E.I. duPont & $\begin{array}{l}\text { Petroleum } \\
\text { refining }\end{array}$ & $\begin{array}{l}\text { Asset } \\
\text { acquisition }\end{array}$ & 1.7 & July \\
\hline $\begin{array}{l}\text { Arakis Energy } \\
\text { Corp. } \\
\text { (Canada) }\end{array}$ & $\begin{array}{l}\text { Oil and gas } \\
\text { exploration and } \\
\text { production }\end{array}$ & $\begin{array}{l}\text { Southern Gas } \\
\text { Co. }\end{array}$ & $\begin{array}{l}\text { Oil and gas } \\
\text { exploration and } \\
\text { prodution }\end{array}$ & $\begin{array}{l}\text { Property } \\
\text { acquisition }\end{array}$ & 0.3 & January \\
\hline $\begin{array}{l}\text { Arakis Energy } \\
\text { Corp. } \\
\text { (Canada) } \\
\text { AKS Energy } \\
\text { Corp. }\end{array}$ & $\begin{array}{l}\text { Oil and gas } \\
\text { exploration and } \\
\text { production }\end{array}$ & $\begin{array}{l}\text { Tri-state } \\
\text { Construction }\end{array}$ & NA & $\begin{array}{l}\text { Property } \\
\text { acquisition }\end{array}$ & 0.2 & January \\
\hline $\begin{array}{l}\text { Sonatrach } \\
\text { Petroleum } \\
\text { Investment } \\
\text { Corp. Ltd. } \\
\text { (Algeria) } \\
\text { Anadarko } \\
\text { Petroleum }\end{array}$ & $\begin{array}{l}\text { Oil and gas } \\
\text { exploration and } \\
\text { production }\end{array}$ & $\begin{array}{l}\text { Panhandle } \\
\text { Eastern Pipeline } \\
\text { Co. }\end{array}$ & $\begin{array}{l}\text { Natural gas } \\
\text { transmission }\end{array}$ & $\begin{array}{l}\text { Asset } \\
\text { acquisition }\end{array}$ & NA & October \\
\hline $\begin{array}{l}\text { Segram Co. Ltd. } \\
\text { (Canada) } \\
\text { E.I. duPont }\end{array}$ & $\begin{array}{l}\text { Integrated } \\
\text { petroleum } \\
\text { operations }\end{array}$ & Marathon Oil & $\begin{array}{l}\text { Oil and gas } \\
\text { exploration and } \\
\text { production }\end{array}$ & $\begin{array}{l}\text { Property } \\
\text { acquisition }\end{array}$ & NA & December \\
\hline $\begin{array}{l}\text { Abdullah Taha } \\
\text { Bakhsh } \\
\text { (Saudi Arabia) } \\
\text { Harken Energy } \\
\text { Corp. }\end{array}$ & $\begin{array}{l}\text { Oil and gas } \\
\text { exploration and } \\
\text { production }\end{array}$ & NA & NA & $\begin{array}{l}\text { Property } \\
\text { acquisition }\end{array}$ & NA & October \\
\hline \multirow{2}{*}{$\begin{array}{l}\text { Louis Dreyfus } \\
\text { et cie } \\
\text { (France) } \\
\text { Louis Dreyfus } \\
\text { Natural Gas } \\
\text { Corp. }\end{array}$} & $\begin{array}{l}\text { Oil and gas } \\
\text { exploration and } \\
\text { production }\end{array}$ & $\begin{array}{l}\text { Prudential } \\
\text { Insurance Co. }\end{array}$ & $\begin{array}{l}\text { Insurance } \\
\text { services, holding } \\
\text { company }\end{array}$ & $\begin{array}{l}\text { Property } \\
\text { acquisition }\end{array}$ & NA & December \\
\hline & & \multicolumn{3}{|c|}{ Divestitures } & & \\
\hline $\begin{array}{l}\text { Pittencrief plc } \\
\text { (United } \\
\text { Kingdom) } \\
\text { Pittencrief } \\
\text { America Inc. } \\
\end{array}$ & $\begin{array}{l}\text { Oil and gas } \\
\text { exploration and } \\
\text { production }\end{array}$ & Keldon Oil Co. & Merger & NA & NA & October \\
\hline
\end{tabular}


Table C1. Completed Transactions by Size in the Petroleum Industry from January 1994 Through December 1994-Acquisitions and Divestitures (Continued)

\begin{tabular}{|c|c|c|c|c|c|c|}
\hline $\begin{array}{l}\text { Acquiring } \\
\text { Company }\end{array}$ & $\begin{array}{c}\text { Acquiring } \\
\text { Company Activity }\end{array}$ & Affected Company & $\begin{array}{l}\text { Affected Company } \\
\text { Activity }\end{array}$ & $\begin{array}{c}\text { Type of } \\
\text { Transaction }\end{array}$ & $\begin{array}{c}\text { Size of } \\
\text { Transaction } \\
\text { (million dollars) }\end{array}$ & $\begin{array}{c}\text { Date of } \\
\text { Transaction }\end{array}$ \\
\hline & & \multicolumn{3}{|c|}{ Divestitures (Continued) } & & \\
\hline $\begin{array}{l}\text { Parker and } \\
\text { Parsley } \\
\text { Petroleum Co. }\end{array}$ & $\begin{array}{l}\text { Oil and gas } \\
\text { exploration and } \\
\text { production }\end{array}$ & $\begin{array}{l}\text { Bridge Oil Ltd. } \\
\text { (Australia) } \\
\text { Bridge Oil USA }\end{array}$ & $\begin{array}{l}\text { Oil and gas } \\
\text { exploration and } \\
\text { production }\end{array}$ & $\begin{array}{l}\text { Asset } \\
\text { acquisition }\end{array}$ & 337.0 & July \\
\hline $\begin{array}{l}\text { Occidental } \\
\text { Petroleum } \\
\text { Corp. }\end{array}$ & $\begin{array}{l}\text { Oil and gas } \\
\text { exploration and } \\
\text { production }\end{array}$ & $\begin{array}{l}\text { ENI } \\
\text { (Italy) } \\
\text { Agip Petroleum } \\
\text { Co. }\end{array}$ & $\begin{array}{l}\text { Integrated } \\
\text { petroleum } \\
\text { operations }\end{array}$ & $\begin{array}{l}\text { Property } \\
\text { acquisition }\end{array}$ & 195.0 & March \\
\hline $\begin{array}{l}\text { Bridge Oil, } \\
\text { (USA) Inc. }\end{array}$ & $\begin{array}{l}\text { Oil and gas } \\
\text { exploration and } \\
\text { production }\end{array}$ & $\begin{array}{l}\text { Andrew Sarlos } \\
\text { (Canada) } \\
\text { Santa Fe Energy } \\
\text { Resources Inc. }\end{array}$ & $\begin{array}{l}\text { Oil and gas } \\
\text { exploration and } \\
\text { production }\end{array}$ & $\begin{array}{l}\text { Property } \\
\text { acquisition }\end{array}$ & 48.0 & April \\
\hline $\begin{array}{l}\text { Octel } \\
\text { Associates }\end{array}$ & $\begin{array}{l}\text { Chemicals } \\
\text { production }\end{array}$ & $\begin{array}{l}\text { Seagrams Co. } \\
\text { (Canada) } \\
\text { E.I. du Pont }\end{array}$ & $\begin{array}{l}\text { Petroleum } \\
\text { refining and } \\
\text { chemicals }\end{array}$ & $\begin{array}{l}\text { Asset } \\
\text { acquisition }\end{array}$ & 41.0 & September \\
\hline $\begin{array}{l}\text { Plains } \\
\text { Petroleum }\end{array}$ & $\begin{array}{l}\text { Oil and gas } \\
\text { exploration and } \\
\text { production }\end{array}$ & $\begin{array}{l}\text { Sonatrach } \\
\text { Petroleum } \\
\text { Investment Corp. } \\
\text { Ltd. (Algeria) } \\
\text { Anadarko } \\
\text { Petroleum Corp. }\end{array}$ & $\begin{array}{l}\text { Oil and gas } \\
\text { exploration and } \\
\text { production }\end{array}$ & $\begin{array}{l}\text { Property } \\
\text { acquisition }\end{array}$ & 24.3 & November \\
\hline $\begin{array}{l}\text { Fuel Resources } \\
\text { Inc. }\end{array}$ & $\begin{array}{l}\text { Oil and gas } \\
\text { exploration and } \\
\text { production }\end{array}$ & $\begin{array}{l}\text { Sonatrach } \\
\text { Petroleum } \\
\text { Investment Corp. } \\
\text { Ltd. (Algeria) } \\
\text { Anadarko } \\
\text { Petroleum Corp. }\end{array}$ & $\begin{array}{l}\text { Oil and gas } \\
\text { exploration and } \\
\text { production }\end{array}$ & $\begin{array}{l}\text { Property } \\
\text { acquisition }\end{array}$ & 23.0 & March \\
\hline Floyd Oil Co. & $\begin{array}{l}\text { Oil and gas } \\
\text { exploration and } \\
\text { production }\end{array}$ & $\begin{array}{l}\text { Friends } \\
\text { Provident Life } \\
\text { (United Kingdom) } \\
\text { Presidio Oil Co. }\end{array}$ & $\begin{array}{l}\text { Oil and gas } \\
\text { exploration and } \\
\text { production }\end{array}$ & $\begin{array}{l}\text { Property } \\
\text { acquisition }\end{array}$ & 15.0 & January \\
\hline $\begin{array}{l}\text { Stone Energy } \\
\text { Corp. }\end{array}$ & $\begin{array}{l}\text { Oil and gas } \\
\text { exploration and } \\
\text { production }\end{array}$ & $\begin{array}{l}\text { Seagrams Co. } \\
\text { (Canada) } \\
\text { E.l. duPont }\end{array}$ & $\begin{array}{l}\text { Oil and gas } \\
\text { exploration and } \\
\text { production }\end{array}$ & $\begin{array}{l}\text { Property } \\
\text { acquisition }\end{array}$ & 11.5 & December \\
\hline NA & NA & $\begin{array}{l}\text { Friends } \\
\text { Provident Life } \\
\text { (United Kingdom) } \\
\text { Presidio Oil Co. }\end{array}$ & $\begin{array}{l}\text { Oil and gas } \\
\text { exploration and } \\
\text { production }\end{array}$ & $\begin{array}{l}\text { Property } \\
\text { acquisition }\end{array}$ & 7.0 & January \\
\hline $\begin{array}{l}\text { Saba Petroleum } \\
\text { Co. }\end{array}$ & $\begin{array}{l}\text { Oil and gas } \\
\text { exploration and } \\
\text { production }\end{array}$ & $\begin{array}{l}\text { Seagrams Co. } \\
\text { (Canada) } \\
\text { E.I. duPont }\end{array}$ & $\begin{array}{l}\text { Petroleum } \\
\text { refining }\end{array}$ & $\begin{array}{l}\text { Asset } \\
\text { acquisition }\end{array}$ & 1.7 & July \\
\hline
\end{tabular}


Table C1. Completed Transactions by Size in the Petroleum Industry from January 1994 Through December 1994-Acquisitions and Divestitures (Continued)

\begin{tabular}{|c|c|c|c|c|c|c|}
\hline $\begin{array}{l}\text { Acquiring } \\
\text { Company }\end{array}$ & $\begin{array}{c}\text { Acquiring } \\
\text { Company Activity }\end{array}$ & Affected Company & $\begin{array}{c}\text { Affected Company } \\
\text { Activity }\end{array}$ & $\begin{array}{c}\text { Type of } \\
\text { Transaction }\end{array}$ & $\begin{array}{c}\text { Size of } \\
\text { Transaction } \\
\text { (million dollars) }\end{array}$ & $\begin{array}{c}\text { Date of } \\
\text { Transaction }\end{array}$ \\
\hline & & \multicolumn{3}{|c|}{ Divestitures (Continued) } & & \\
\hline $\begin{array}{l}\text { Parker and } \\
\text { Parsley } \\
\text { Petroleum Co. }\end{array}$ & $\begin{array}{l}\text { Oil and gas } \\
\text { exploration and } \\
\text { production }\end{array}$ & $\begin{array}{l}\text { Bridge Oil Ltd. } \\
\text { (Australia) } \\
\text { Bridge Oil USA }\end{array}$ & $\begin{array}{l}\text { Oil and gas } \\
\text { exploration and } \\
\text { production }\end{array}$ & $\begin{array}{l}\text { Asset } \\
\text { acquisition }\end{array}$ & 337.0 & July \\
\hline $\begin{array}{l}\text { Odessa } \\
\text { Exploration Inc. }\end{array}$ & $\begin{array}{l}\text { Oil and gas } \\
\text { exploration and } \\
\text { production }\end{array}$ & $\begin{array}{l}\text { Seagrams Co. } \\
\text { (Canada) } \\
\text { E.I. duPont }\end{array}$ & $\begin{array}{l}\text { Oil and gas } \\
\text { exploration and } \\
\text { production }\end{array}$ & $\begin{array}{l}\text { Property } \\
\text { acquisition }\end{array}$ & NA & April \\
\hline GHK Co. & NA & $\begin{array}{l}\text { Sonatrach } \\
\text { Petroleum } \\
\text { Investment Corp. } \\
\text { Ltd. (Algeria) } \\
\text { Anadarko } \\
\text { Petroleum Corp. }\end{array}$ & $\begin{array}{l}\text { Oil and gas } \\
\text { exploration and } \\
\text { production }\end{array}$ & $\begin{array}{l}\text { Property } \\
\text { acquisition }\end{array}$ & NA & May \\
\hline $\begin{array}{l}\text { Torch Energy } \\
\text { Advisors Inc. }\end{array}$ & $\begin{array}{l}\text { Oil and gas asset } \\
\text { management }\end{array}$ & $\begin{array}{l}\text { British Petroleum } \\
\text { plc } \\
\text { (United Kingdom) } \\
\text { BP America }\end{array}$ & $\begin{array}{l}\text { Oil and gas } \\
\text { exploration and } \\
\text { production }\end{array}$ & $\begin{array}{l}\text { Property } \\
\text { acquisition }\end{array}$ & NA & August \\
\hline Venoco inc. & $\begin{array}{l}\text { Oil and gas } \\
\text { exploration and } \\
\text { production }\end{array}$ & $\begin{array}{l}\text { Capco } \\
\text { Resources } \\
\text { (Canada) } \\
\text { Saba Petroleum } \\
\text { Co. }\end{array}$ & $\begin{array}{l}\text { Oil and gas } \\
\text { exploration and } \\
\text { production }\end{array}$ & $\begin{array}{l}\text { Property } \\
\text { acquisition }\end{array}$ & NA & November \\
\hline
\end{tabular}

$\mathrm{NA}=$ Not available.

Sources: see page 163. 
Table C2. Completed Transactions by Size in the Coal Industry from January 1994 Through December 1994-Acquisitions and Divestitures

\begin{tabular}{|c|c|c|c|c|c|c|}
\hline & & \multicolumn{3}{|c|}{ Acquisitions } & & \\
\hline $\begin{array}{l}\text { Hanson plc } \\
\text { (United Kingdom) } \\
\text { Peabody Holding } \\
\text { Co. }\end{array}$ & $\begin{array}{l}\text { Coal mining } \\
\text { operations }\end{array}$ & $\begin{array}{l}\text { Exxon Corp. } \\
\text { Carter Mining } \\
\text { Co. }\end{array}$ & $\begin{array}{l}\text { Coal mining } \\
\text { operations }\end{array}$ & $\begin{array}{l}\text { Asset } \\
\text { acquisition }\end{array}$ & 360.0 & October \\
\hline $\begin{array}{l}\text { RTZ Corp. ple } \\
\text { (United Kingdom) } \\
\text { Kennecott Corp. }\end{array}$ & $\begin{array}{l}\text { Metals, coal } \\
\text { mining }\end{array}$ & $\begin{array}{l}\text { WR Grace } \\
\text { Colowyo Coal }\end{array}$ & $\begin{array}{l}\text { Coal mining } \\
\text { operations }\end{array}$ & $\begin{array}{l}\text { Asset } \\
\text { acquisition }\end{array}$ & 233.0 & November \\
\hline \multirow[t]{2}{*}{$\begin{array}{l}\text { RWE AG } \\
\text { (Germany) } \\
\text { Consol Energy }\end{array}$} & $\begin{array}{l}\text { Coal mining } \\
\text { operations }\end{array}$ & $\begin{array}{l}\text { Westmoreland } \\
\text { Coal } \\
\text { Criterion Coal }\end{array}$ & $\begin{array}{l}\text { Coal mining } \\
\text { operations }\end{array}$ & $\begin{array}{l}\text { Asset } \\
\text { acquisition }\end{array}$ & 81.0 & July \\
\hline & & \multicolumn{3}{|c|}{ Divestitures } & & \\
\hline NA & NA & $\begin{array}{l}\text { Royal } \\
\text { Dutch/Shell } \\
\text { Group } \\
\text { (United } \\
\text { Kingdom/ } \\
\text { Netherlands) } \\
\text { Zeigler Coal }\end{array}$ & $\begin{array}{l}\text { Coal mining } \\
\text { operations }\end{array}$ & $\begin{array}{l}\text { Equity } \\
\text { acquisition }\end{array}$ & 618.0 & January \\
\hline $\begin{array}{l}\text { Catenary Coal } \\
\text { Holding }\end{array}$ & $\begin{array}{l}\text { Coal mining } \\
\text { operations }\end{array}$ & $\begin{array}{l}\text { ENI (Italy) } \\
\text { Agip Coal } \\
\text { Holding USA }\end{array}$ & $\begin{array}{l}\text { Coal mining } \\
\text { operations }\end{array}$ & $\begin{array}{l}\text { Asset } \\
\text { acquisition }\end{array}$ & 150.0 & January \\
\hline
\end{tabular}

NA=not available

Sources: see page 163. 



\section{Sources}

Informational material used in compiling Tables $\mathrm{C} 1$ and C2:

- The Wall Street Journal, various issues, 1994 and 1995.

- Business Week, various issues.

- Company financial reports: annual reports to stockholders, annual reports on Securities and Exchange Commission (SEC) Form 10-K, and filings on SEC Schedule 13-D.

- Moody's International Manual, 1994 and 1995. Moody's Investors Service, New York, NY.

- Oil and Gas Journal, various issues, 1994 and 1995. Pennwell Publishing Company, Tulsa, OK.

- SEC News Digest, selected issues, 1994. U.S. Securities and Exchange Commission, Washington, DC.
- The Merger Yearbook U.S./International Edition 1995. Securities Data Company, New York, NY.

- Oil and Gas Investor, September 1994 and April 1995. Hart Publications, Inc., Denver, CO.

- U.S. Oil Week, various issues, 1994 and 1995. Capital Publishing Group, Alexandria, VA.

- Coal, various issues, 1994 and 1995. Maclean Hunter Publishing Co., Chicago, IL.

- Coal Outlook, various issues, 1994. Pasha Publications, Arlington, VA.

- Company press releases. 



\section{Glossary}

Acquisition Costs: Direct costs and indirect costs incurred to acquire legal rights to wasting natural resources. Direct costs include costs incurred to obtain options to lease or purchase mineral rights and costs incurred for the actual leasing (e.g., lease bonuses) or purchasing of the rights. Indirect costs include such costs as: brokers' commissions and expenses; abstract and recording fees; filing and patenting fees; and costs of legal examination of title and documents.

Acreage: An area, measured in acres, that is subject to ownership or control by those holding total or fractional shares of working interests. Acreage is considered developed when development has been completed. (See definition for Working Interest.) A distinction may be made between "gross" acreage and "net" acreage:

- Gross. All acreage covered by any working interest, regardless of the percentage of ownership in the interest.

- Net. Gross acreage adjusted to reflect the percentage of ownership in the working interest in the acreage.

Affiliate: An "affiliate" of, or a person "affiliated" with, a specific person is a person that directly, or indirectly through one or more intermediaries, controls, or is controlled by, or is under common control with, the person specified. The term "affiliate" includes any subsidiary or parent of the person specified.

Amortization: The depreciation, depletion, or charge-off to expense of intangible and tangible assets over a period of time. In the extractive industries, the term is most frequently applied to mean either (1) the periodic chargeoff to expense of the costs associated with nonproducing mineral properties incurred prior to the time when they are developed and entered into production or (2) the systematic charge-off to expense of those costs of productive mineral properties (including tangible and intangible costs of prospecting, acquisition, exploration, and development) that had been initially capitalized (or deferred) prior to the time the properties entered into production, and thereafter are charged off as minerals are produced.

Branded Product: A refined petroleum product sold by a refiner with the understanding that the purchaser has the right to resell the product under a trademark, trade name, service mark, or other identifying symbol or names owned by such refiner.

Christmas Tree: The valves and fittings installed at the top of a gas or oil well to control and direct the flow of well fluids.

Coal Gasification: The process of converting coal into gas. The basic process involves crushing coal to a powder, which is then heated in the presence of steam and oxygen to produce a gas. The gas is then refined to reduce sulfur and other impurities. The gas can be used as a fuel or processed further and concentrated into chemical or liquid fuel.

Coal Liquefaction: A chemical process that converts coal into clean-burning liquid hydrocarbons, such as synthetic crude oil and methanol.

Coal Regions: The following regional definitions are used to report domestic coal reserves, production, and other operating statistics.

- Eastern Region. Consists of the Northern Appalachian Coal Basin. The following States comprise the Eastern Region: Alabama, Georgia, Ohio, Maryland, Mississippi, Pennsylvania, Virginia, Tennessee, North Carolina, West Virginia, and Eastern Kentucky.

- Midwest Region. Consists of the Illinois and Michigan Coal Basins. The following States comprise the Midwest Region: Illinois, Indiana, Michigan, and Western Kentucky.

- Western Region. Consists of the Northern Rocky, Southern Rocky, Western Interior, and West Coast Coal Basins. The following States comprise the Central Western Region: Alaska, Arizona, Arkansas, California, Colorado, Idaho, Iowa, Kansas, Louisiana, Missouri, Montana, New Mexico, North Dakota, Oklahoma, Oregon, Texas, South Dakota, Utah, Washington, and Wyoming.

Company Automotive (Retail) Outlet: Any retail outlet selling motor fuel under a reporting company brand name. (See definition for Branded Product.) 
- Company Operated. A company retail outlet which is operated by salaried or commission personnel paid by the reporting company.

- Lessee. An independent marketer who leases the station and land and has use of tanks, pumps, signs, etc. A lessee dealer typically has a supply agreement with a refiner or a distributor and purchases products at dealer tank wagon prices. The term "lessee dealer" is limited to those dealers who are supplied directly by a refiner or any affiliate or subsidiary company of a refiner. "Direct supply" includes use of commission agent or common carrier delivery.

- Open. An independent marketer who owns or leases (from a third party who is not a refiner) the station or land of a retail outlet and has use of tanks, pumps, signs, etc. An open dealer typically has a supply agreement with a refiner or a distributor and purchases products at or below dealer tank wagon prices.

Contribution to Net Income: The FRS segment equivalent of net income. However, many consolidated items of revenue and expense are not allocated to the segments, and therefore they are not equivalent in a strict sense. The largest item not allocated to the segments is interest expense since this is regarded as a corporate-level item for FRS purposes.

Crude Oil: A mixture of hydrocarbons that exists in liquid phase in natural underground reservoirs and remains liquid at atmospheric pressure after passing through surface separating facilities. For FRS reporting, volumes reported as crude include:

- Liquids technically defined as crude oil.

- Small amounts of hydrocarbons that exist in the gaseous phase in natural underground reservoirs but are liquid at atmospheric pressure after being recovered from oil well (casinghead) gas in lease separators and are commingled with the crude stream without being separately measured.

- Small amounts of nonhydrocarbons produced with the oil.

Statistical data pertaining to crude oil production and reserves are reported as liquid equivalents at the surface (excluding base sediment and water) measured in terms of stock tank barrels of 42 U.S. gallons at atmospheric pressure, corrected to 60 degrees Fahrenheit.
Where a State regulatory agency specifies a definition of crude oil which differs from that set forth above for statistical purposes, the State definition should be followed.

DD\&A: Abbreviation for depreciation, depletion, and amortization.

Deferred Taxes: Taxes accrued and reflected as an expense in a company's income statement but not payable to the taxing authority in that time period. These taxes are accrued to compensate for an understatement of income tax expense which would occur if only the tax currently due to the taxing authority were reflected as the total income tax expense.

Depletion: A term for either (1) a periodic assignment to expense of recorded amounts or (2) an allowable income tax deduction that is related to the exhaustion of mineral reserves. Depletion is included as one of the elements of amortization. When used in that manner, depletion refers only to book depletion (see definition for Amortization).

- Book. The portion of the carrying value (other than the portion associated with tangible assets) prorated in each accounting period, for financial reporting purposes, to the extracted portion of an economic interest in a wasting natural resource.

- Tax-cost. A deduction (allowance) under U.S. Federal Income taxation normally calculated under a formula whereby the adjusted basis of the mineral property is multiplied by a fraction, the numerator of which is the number of units of minerals sold during the tax year and the denominator of which is the estimated number of units of unextracted minerals remaining at the end of the tax year plus the number of units of minerals sold during the tax year.

- Tax-percentage (or Statutory). A deduction (allowance) allowed to certain mineral producers under U.S. Federal income taxation calculated on the basis of a specified percentage of gross revenue from the sale of minerals from each mineral property not to exceed the lesser of 50 percent of the taxable income from the property computed without allowance for depletion. (There are also other limits on percentage depletion on oil and gas production). The taxpayer is entitled to a deduction representing the amount of tax-cost depletion or percentage (statutory) depletion, whichever is higher.

- Excess Statutory Depletion. The excess of estimated statutory depletion allowable as an income tax 
deduction over the amount of cost depletion otherwise allowable as a tax deduction, determined on a total enterprise basis.

Depreciation: See definition for Amortization.

Development: The preparation of a specific mineral deposit for commercial production; this preparation includes construction of access to the deposit and of facilities to extract the minerals. The development process is sometimes further distinguished between a preproduction stage and a current stage, with the distinction being made on the basis of whether the development work is performed before or after production from the mineral deposit has commenced on a commercial scale.

Development Costs: Costs incurred to obtain access to proved reserves and to provide facilities for extracting, treating, gathering, and storing the oil and gas. More specifically, development costs, and also depreciation and applicable operating costs of support equipment and facilities and other costs of development activities, are costs incurred to:

- Gain access to and prepare well locations for drilling, including surveying well locations for the purpose of determining specific development drilling sites, clearing ground, draining, road building, and relocating public roads, gas lines, and power lines, to the extent necessary in developing the proved reserves;

- Drill and equip development wells, development-type stratigraphic test wells, and service wells including the costs of platforms and of well equipment such as casing, tubing, pumping equipment, and the wellhead assembly;

- Acquire, construct, and install production facilities such as lease flow lines, separators, treaters, heaters, manifolds, measuring devices, and production storage tanks, natural gas cycling and processing plants, and utility waste disposal systems; and

- Provide improved recovery systems.

Distillate: A general classification for one of the petroleum fractions produced in conventional distillation operations. Included are kerosene and products known as heating oils and diesel fuels, specifically: No. 1, No. 2, and No. 4 Fuel Oils and No. 1, No. 2, and No. 4 Diesel Fuels.

Domestic Operations: Domestic operations are those operations located in the United States.
- The United States is defined as the 50 States, including their offshore territorial waters, the District of Columbia, U.S. commonwealth territories, and protectorates.

Drilling: The act of boring a hole (1) to determine whether minerals are present in commercially recoverable quantities and (2) to accomplish production of the minerals (including drilling to inject fluids).

- Exploratory. Drilling to locate probable mineral deposits or to establish the nature of geological structures; such wells may not be capable of production if minerals are discovered.

- Developmental. Drilling to delineate the boundaries of a known mineral deposit to enhance the productive capacity of the producing mineral property.

- Directional. Drilling that is deliberately made to depart significantly from the vertical.

Drilling and Equipping of Wells: The drilling and equipping of wells through completion of the "christmas tree."

Dry-Hole Charge: The charge-off to expense of a previously capitalized cost upon the conclusion of an unsuccessful drilling effort.

Equity in Earnings of Unconsolidated Affiliates: A company's proportional share (based on ownership) of the net earnings or losses of an unconsolidated affiliate.

Exploration: The identification of areas that may warrant examination and to examine specific areas that are considered to have prospects of containing oil and gas reserves, including drilling exploratory wells and exploratory-type stratigraphic test wells. Exploration costs may be incurred both before acquiring the related property (sometimes referred to in part as prospecting costs) and after acquiring the property.

Exploration Costs: Costs, including depreciation and applicable operating costs, of support equipment and facilities and other costs directly identifiable with exploration activities, such as:

- Costs of topographical, geological, and geophysical studies, rights of access to properties to conduct those studies, and salaries and other expenses of geologists, geophysical crews, and others conducting those studies. Collectively, these costs are sometimes 
referred to as geological and geophysical, or "G\&G," costs.

- Costs of carrying and retaining undeveloped properties, such as delay rentals, ad valorem taxes on the properties, legal costs for title defense, and the maintenance of land and lease records.

- Dry hole contributions and bottom hole contributions. Costs of drilling and equipping exploratory wells.

- Costs of drilling exploratory-type stratigraphic test wells.

Extraordinary Item: Income and expense items associated with events and transactions that possess a high degree of abnormality and are of a type that would not reasonably be expected to recur in the foreseeable future.

Field: An area consisting of a single reservoir or multiple reservoirs all grouped on or related to the same individual geological structural feature and/or stratigraphic condition. There may be two or more reservoirs in a field which are separated vertically by intervening impervious strata, or laterally by local geologic barriers, or by both.

Footage Drilled: Total footage for wells in various categories, as reported for any specified period, includes (1) the deepest total depth (length of well bores) of all wells drilled from the surface, (2) the total of all bypassed footage drilled in connection with reported wells, and (3) all new footage drilled for directional "sidetrack" wells. Footage reported for directional "sidetrack" wells does not include footage in the common bore which is reported as footage for the original well. In the case of old wells drilled deeper, the reported footage is that which was drilled below the total depth of the old well.

- Deepest Total Depth. The deepest total depth of a given well is the distance from a surface reference point (usually the Kelly bushing) to the point of deepest penetration measured along the well bore. If a well is drilled from a platform or barge over water, the depth of the water is included in the total length of the well bore.

- Sidetrack Drilling. This is a remedial operation that results in the creation of a new section of well bore for the purpose of (1) detouring around junk, (2) redrilling lost hole, or (3) straightening key seats and crooked holes. Directional "sidetrack" wells do not include footage in the common bore, which is reported as footage for the original well.
Foreign Access: Refers to proved reserves of crude (including lease condensate) and natural gas liquids applicable to long-term supply agreements with foreign governments or authorities in which the company acts as producer.

Foreign Operations: These are operations that are located outside the United States. Determination of whether an enterprise's mobile assets, such as offshore drilling rigs or ocean-going vessels, constitute foreign operations should depend on whether such assets are normally identified with operations located outside the United States.

Foreign operations are segregated into the following areas for FRS reporting purposes:

- OECD Europe. Includes Austria, Belgium, Denmark, Finland, France, the Federal Republic of Germany, Greece, Iceland, Ireland, Italy, Luxembourg, the Netherlands, Norway, Portugal, Spain, Sweden, Switzerland, Turkey, and the United Kingdom.

- Former Soviet Union (FSU) and East Europe. The Baltic States of Estonia, Latvia, and Lithuania, as well as Armenia, Azerbaijan, Belarus, Georgia, Kazakhstan, Kyrgystan, Moldova, Russia, Tajikstan, Turkmenistan, Ukraine, Uzbekistan, Albania, Bulgaria, Czech Republic, Hungary, Poland, Romania, Slovakia, and Yugoslavia.

- Middle East. Includes Saudi Arabia, the United Arab Emirates, Iraq, Iran, Kuwait, the Iraq-Saudi Arabia Neutral Zone, Qatar, Dubai, Bahrain, Oman, Yemen, Syria, Jordan, and Israel.

- Canada.

- Africa (the African continent).

- Other Eastern Hemisphere. Areas eastward of the Greenwich prime meridian to 180 degrees longitude and not included in other specified domestic or foreign classifications.

- Other Western Hemisphere. Areas westward of the Greenwich prime meridian to 180 degrees longitude not included in other domestic or foreign classifications.

Funds From Operations: Calculated by adding noncash charges back to net income or contribution to net income. Deferred taxes and depreciation, depletion, and amortization (DD\&A) are the largest noncash charges. 
Funds, Total Sources of: The total source of funds includes net income plus noncash charges such as DD\&A and deferred taxes, issuances of stocks and bonds, and proceeds from the sale or property, plant, and equipment. The concept is similar to cash flow generated but does not attempt to account for changes in working capital items. Thus, for example, an inventory buildup or drawdown would not be accounted for under the "funds" concept since both cash and inventory are items of working capital.

Geological and Geophysical (G\&G) Costs: Costs incurred in making geological and geophysical studies, including, but not limited to, costs incurred for salaries, equipment, obtaining rights of access, and supplies for scouts, geologists, and geophysical crews.

Hydrocarbon: An organic chemical compound of hydrogen and carbon in either the gaseous, liquid, or solid phase. The molecular structure of hydrocarbon compounds varies from the simplest (e.g., methane, a constituent of natural gas) to the very heavy and very complex.

Improved Recovery: The operation whereby crude oil or natural gas is recovered by use of any method other than those that rely primarily on the use of natural reservoir pressure, gas lift, or a pump.

Intangible Drilling and Development Costs (IDC): Costs incurred in preparing well locations, drilling and deepening wells, and preparing wells for initial production up through the point of installing control valves. None of these functions, because of their nature, have salvage value. Such costs would include labor, transportation, consumable supplies, drilling tool rentals, site clearance, and similar costs.

Investment and Advances to Unconsolidated Affiliates: The balance sheet account representing the cost of investments and advances to unconsolidated affiliates. Generally, affiliates which are less than 50 percent owned by a company may not be consolidated into the company's financial statements.

Lease Bonus: An amount paid by a lessee to a lessor as consideration for granting a lease, usually as a lump sum; this payment is in addition to any rental or royalty payments.

Lease Equipment: All equipment located on the lease except the well and the complete christmas tree installation.
Lifting Costs: The costs associated with the extraction of a mineral reserve from a producing property. (See definition for Production Cost.)

Mineral: Any of the various naturally occurring substances (such as coal, crude oil, metals, natural gas, salt, sand, stone, sulfur, and water) usually obtained from the earth. The term is used to include all wasting, i.e., nonregenerative, inorganic substances that are extracted from the earth.

Mineral Interests in Properties (hereinafter referred to as Properties): These include fee ownership or a lease, concession, or other contractual interest representing the right to extract minerals subject to such terms as may be imposed by the conveyance of those interests. Properties also include royalty interests, production payments payable in oil or gas, and other nonoperating interests in properties operated by others. Properties include those agreements with foreign governments or authorities under which an enterprise participates in the operation of the related properties or otherwise serves as "producer" of the underlying reserves, but properties do not include other supply agreements or contracts that represent the right to purchase (as opposed to extract) oil and gas.

Mineral Lease: An agreement wherein a mineral interest owner (lessor) conveys to another party (lessee) the rights to explore for, develop, and produce specified minerals. The lessee acquires a working interest and the lessor retains a nonoperating interest in the property, referred to as the royalty interest, each in proportions agreed upon.

Mineral Rights: The ownership of the minerals beneath the earth's surface with the right to remove them. Mineral rights may be conveyed separately from surface rights.

Mining: Any activity directed to the extraction of ore and associated rock. Included are open pit work, quarrying, augering, alluvial dredging, and combined operations, including surface and underground operations.

Minority Interest in Income: The proportional share of the minority ownership's interest (less than 50 percent) in the earnings or losses of the consolidated subsidiary.

Subsidiaries are generally fully consolidated when a share of ownership between 51 percent and 100 percent is held by the parent. In consolidation, 100 percent of revenues, expenses, assets, etc. are included in the financial statements even though, for example, the subsidiary is only 80 percent owned by the parent company. In such cases, the consolidated balance sheet must have a caption on the right-hand side titled something like "minority interests in consolidated affiliates," and the income 
statement must have a similar line to reduce net income to the pro rata ( 80 percent in this example) share of the consolidated subsidiary's net income.

Motor Gasoline (Finished): A complex mixture of relatively volatile hydrocarbons, with or without small quantities of additives, that has been blended to form a fuel suitable for use in spark-ignition engines. Motor gasoline, as given in ASTM Specification D439 or Federal Specification VV-G-1690B, includes a range in distillation temperatures from 122 to 158 degrees Fahrenheit at the 10-percent recovery point and from 365 to 374 degrees Fahrenheit at the 90-percent recovery point. Motor gasoline includes reformulated motor gasoline, oxygenated motor gasoline, and other finished motor gasoline. Blendstock is excluded until blending has been completed.

- Reformulated Motor Gasoline. Gasoline reformulated for use in motor vehicles, the composition and properties of which meet the requirements of the reformulated gasoline regulations promulgated by the U.S. Environmental Protection Agency under Section $211 \mathrm{~K}$ of the Clean Air Act.

- Oxygenated Gasoline. Gasoline formulated for use in motor vehicles that has an oxygen content of 1.8 percent or higher, by weight. Includes gasohol.

- Other Finished Gasoline. Motor Gasoline not included in the oxygenated or reformulated gasoline categories.

Motor Gasoline, Finished Gasohol: A blend of finished motor gasoline (leaded or unleaded) and alcohol (generally ethanol but sometimes methanol), limited to 10 percent by volume of alcohol.

Motor Gasoline, Finished Leaded: Contains more than 0.05 gram of lead per gallon or more than 0.005 gram of phosphorus per gallon. Premium and regular grades are included, depending on the octane rating. Includes leaded gasohol. Blendstock is excluded until blending has been completed. Alcohol that is to be used in the blending of gasoline is excluded.

Motor Gasoline, Finished Unleaded: Contains not more than 0.05 gram of lead per gallon and not more than 0.005 gram of phosphorus per gallons. Premium and regular grades are included, depending on the octane rating. Includes unleaded gasohol. Blendstock is excluded until blending has been completed. Alcohol that is to be used in the blending of gasohol is also excluded.
MTBE (Methyl tertiary butyl ether) (CH3)3C) CH: An ether intended for motor gasoline blending. (See definition for Oxygenates.)

Natural Gas: A mixture of hydrocarbon compounds and small quantities of various nonhydrocarbons existing in the gaseous phase or in solution with crude oil in natural underground reservoirs at reservoir conditions. The principal hydrocarbons usually contained in the mixture are methane, ethane, propane, butanes, and pentanes. Typical nonhydrocarbon bases which may be present in reservoir natural gas are carbon dioxide, helium, hydrogen sulfide, and nitrogen. Under reservoir conditions, natural gas and the liquefiable portions thereof occur either in a single gaseous phase in the reservoir or in solution with crude oil and are not distinguishable at that time as separate substances.

Natural gas, based on the type of occurrence in the reservoir, is classified by two categories, as follows:

- Non-Associated Gas is natural gas that is not in contact with significant quantities of crude oil in the reservoir.

- Associated/Dissolved Gas is the combined volume of natural gas which occurs in crude oil reservoirs either as free gas (associated) or as gas in solution with crude oil (dissolved).

Associated gas is free natural gas, commonly known as gas cap gas, which overlies and is in contact with crude oil in the reservoir. Dissolved gas is natural gas that is in solution with crude oil in the reservoir at reservoir conditions.

Statistical data pertaining to natural gas production and reserves are reported in units of $1,000,000$ cubic feet (i.e., MMCF) at 14.73 pounds per square inch absolute and 60 degrees Fahrenheit for FRS purposes.

Natural Gas Liquids (NGL): Natural gas liquids are those portions of reservoir gas which are liquefied at the surface in lease separators, field facilities, or gas processing plants. Natural gas liquids include but are not limited to: ethane, propane, butanes, pentanes, natural gasoline, and condensate.

Net Investment in Place: The sum of net property, plant, and equipment (PP\&E) plus investment and advances to unconsolidated affiliates.

Nonbranded Product: Any refined petroleum product that is not a branded product. 
Nuclear Fuel Operations: All nuclear fuel operations, excluding reactor and reactor component manufacturing or containment construction. Includes exploration and development; mining; milling; conversion; enrichment; fabrication; reprocessing; and spent fuel storage.

Offshore: That geographic area that lies seaward of the coastline. In general, the coastline is the line of ordinary low water along with that portion of the coast that is in direct contact with the open sea or the line marking the seaward limit of inland water.

If a State agency uses a different basis for classifying onshore and offshore areas, the State classification should be used. (Cook Inlet in Alaska is classified as offshore.)

Oil Shale: A sedimentary rock containing kerogen, a solid organic material.

Operating Expenses: Segment expenses related both to revenue from sales to unaffiliated customers and revenue from intersegment sales or transfers, excluding loss on disposition of property, plant, and equipment; interest expenses and financial charges; foreign currency translation effects; minority interest; and income taxes.

Operating Income: Operating revenues less operating expenses. Excludes items of other revenue and expense, such as equity in earnings of unconsolidated affiliates, dividends, interest income and expense, income taxes, extraordinary items, and cumulative effect of accounting changes.

Operating Revenues: Segment revenues both from sales to unaffiliated customers (i.e., revenue from customers outside the enterprise as reported in the company's consolidated income statement) and from intersegment sales or transfers, if any, of product and services similar to those sold to unaffiliated customers, excluding equity in earnings of unconsolidated affiliates; dividend and interest income; gain on disposition of property, plant, and equipment; and foreign currency translation effects.

Other Energy Operations: Energy operations not included in Petroleum or Coal. Other Energy includes nuclear, oil shale, tar sands, coal liquefaction and gasification, geothermal, solar, and other forms of nonconventional energy.

Oxygenates: Any substance which, when added to gasoline, increases the amount of oxygen in that gasoline blend. Through a series of waivers and interpretive rules, the Environment Protection Agency (EPA) has determined the allowable limits for oxygenates in unleaded gasoline. The "Substantially Similar" Interpretive Rules (56 FR (February 11, 1991)) allows blends of aliphatic alcohols other than methanol and aliphatic ethers, provided the oxygen content does not exceed 2.7 percent by weight. The "Substantially Similar" Interpretive Rules also provide for blends of methanol up to 0.3 percent by volume exclusive of other oxygenates, and butanol or alcohols of a higher molecular weight up to 2.75 percent by weight. Individual waivers pertaining to the use of oxygenates in unleaded gasoline have been issued by the EPA. They include:

- Fuel Ethanol. Blends of up to 10 percent by volume anhydrous ethanol (200 proof) (commonly referred to as the "gasohol waiver").

- Methanol. Blends of methanol and gasoline-grade tertiary butyl alcohol (GTBA) such that the total oxygen content does not exceed 3.5 percent by weight and the ratio of methanol to GTBA is less than or equal to 1 . It is also specified that this blended fuel must meet American Society for Testing and Materials (ASTM) volatility specifications (commonly referred to as the "ARCO" waiver).

Blends of up to 5.0 percent by volume methanol with a minimum of 3.5 percent by volume cosolvent alcohols having a carbon number of 4 or less (i.e., ethanol, propanol, butanol, and/or GTBA). The total oxygen must not exceed 3.7 percent by weight, and the blend must meet ASTM volatility specifications as well as phase separation and purity specifications (commonly referred to as the "DuPont" waiver).

- MTBE (Methyl tertiary butyl ether). Blends up to 15.0 percent by volume MTBE which must meet the ASTM D4814 specifications. Blenders must take precautions that the blends are not used as base gasolines for other oxygenated blends (commonly referred to as the "Sun" waiver).

PP\&E, Additions to: The current year's expenditures on property, plant, and equipment (PP\&E). The amount is predicated upon each reporting company's accounting practice. That is, accounting practices with regard to capitalization of certain items may differ across companies, and therefore this figure in FRS will be a function of each reporting company's policy.

PP\&E, Net: The original cost of property, plant, and equipment (PP\&E), less accumulated depreciation.

Petroleum: Hydrocarbon mixtures broadly defined to include crude oil, lease condensate, natural gas, products of natural gas processing plants (plant products), refined 
products, and semifinished products and blending materials.

Pipelines, Rate Regulated: FRS establishes three pipeline segments: crude/liquid (raw materials); natural gas; and refined products. The pipelines included in these segments are all Federally or State rate-regulated pipeline operations, which are included in the reporting company's consolidated financial statements. However, at the reporting company's option, intrastate pipeline operations may be included in the U.S. Refining/ Marketing Segment if: they would comprise less than 5 percent of U.S. Refining/Marketing Segment net PP\&E, revenues, and earnings in the aggregate; and if the inclusion of such pipelines in the consolidated financial statements adds less than $\$ 100$ million to the net PP\&E reported for the U.S. Refining/Market Segment.

Primary Recovery: The crude oil or natural gas recovered by any method that may be employed to produce them where the fluid enters the well bore by the action of natural reservoir pressure (energy or gravity).

Primary Transportation: Conveyance of large shipments of petroleum raw materials and refined products usually by pipeline, barge, or ocean-going vessel. All crude oil transportation is primary, including the small amounts moved by truck. All refined product transportation by pipeline, barge, or ocean-going vessel is primary transportation.

Producing Property: A term often used in reference to a property, well, or mine that produces wasting natural resources. The term means a property that produces in paying quantities (that is, one for which proceeds from production exceed operating expenses).

Production, Natural Gas Liquids: Production of natural gas liquids is classified as follows:

- Contract Production. Natural gas liquids accruing to a company because of its ownership of liquids extraction facilities that it uses to extract liquids from gas belonging to others, thereby earning a portion of the resultant liquids.

- Leasehold Production. Natural gas liquids produced, extracted, and credited to a company's interest.

- Contract Reserves. Natural gas liquid reserves corresponding to the contract production defined above.
- Leasehold Reserves. Natural gas liquid reserves corresponding to the leasehold production defined above.

Production, Oil and Gas: The lifting of the oil and gas to the surface and gathering, treating, field processing (as in the case of processing gas to extract liquid hydrocarbons), and field storage. The production function shall normally he regarded as terminating at the outlet valve on the lease or field production storage tank; if unusual physical or operational circumstances exist, it may be more appropriate to regard the production function as terminating at the first point at which oil, gas, or gas liquids are delivered to a main pipeline, a common carrier, a refinery, or a marine terminal.

- Gross Company-Operated Production. Total production from all company-operated properties, including all working and nonworking interests.

- Net Working Interest Production. Total production accruing to the reporting company's working interests less royalty oil and volumes due others.

Production Costs: Costs incurred to operate and maintain wells and related equipment and facilities, including depreciation and applicable operating costs of support equipment and facilities and other costs of operating and maintaining those wells and related equipment and facilities. They become part of the cost of oil and gas produced. The following are examples of production costs (sometimes called lifting costs):

- Costs of labor to operate the wells and related equipment and facilities.

- Repair and maintenance costs.

- The costs of materials, supplies, and fuel consumed and services utilized in operating the wells and related equipment and facilities.

- The costs of property taxes and insurance applicable to proved properties and wells and related equipment and facilities.

- The costs of severance taxes.

Depreciation, depletion, and amortization (DD\&A) of capitalized acquisition, exploration, and development costs are not production costs but also become part of the cost of oil and gas produced along with production (lifting) costs identified above. 
Production costs include the following subcategories of costs:

- Well operations and maintenance

- Well workovers

- Operating fluid injection and improved recovery programs

- Operating gas processing plants

- Ad valorem taxes

- Production or severance taxes

- Other, including overhead.

Research and Development: Basic and applied research in the sciences and engineering and the design and development of prototypes and processes, excluding quality control, routine product testing, market research, sales promotion, sales service, research in the social sciences or psychology, and other non-technological activities or technical services.

Reserves, Change in: For FRS reporting, the following definitions should be used for changes in reserves.

- Revisions of Previous Estimates. Changes in previous estimates of proved reserves, either upward or downward, resulting from new information normally obtained from development drilling and production history or resulting from a change in economic factors. Revisions do not include changes in reserve estimates resulting from increases in proved acreage or from improved recovery techniques.

- Improved Recovery. Changes in reserve estimates resulting from application of improved recovery techniques shall be separately shown, if significant. If not significant, such changes shall be included in revisions of previous estimates.

- Purchases or Sales of Minerals-in-Place. Increase or decrease in the estimated quantity of reserves resulting from the purchase or sale of mineral rights in land with known proved reserves.

- Extensions, Discoveries, and Other Additions. Additions to an enterprise's proved reserves that result from (1) extension of the proved acreage of previously discovered (old) reservoirs through additional drilling in periods subsequent to discovery and (2) discovery of new fields with proved reserves or of new reservoirs of proved reserves in old fields.

Reserves (Coal): Coal reserve estimates comprising the demonstrated coal reserve base inciude only proved (measured) and probable (indicated).

- Proved (Measured) Reserves. Reserves or resources for which tonnage is computed from dimensions revealed in outcrops, trenches, workings, and drill holes and for which the grade is computed from the results of detailed sampling. The sites for inspection, sampling, and measurement are spaced so closely and the geologic character is so well defined that size, shape, and mineral content are well established. The computed tonnage and grade are judged to be accurate within limits which are stated, and no such limit is judged to be different from the computed tonnage or grade by more than 20 percent.

- Probable (Indicated) Reserves. Reserves or resources for which tonnage and grade are computed partly from specific measurements, samples, or production data and partly from projection for a reasonable distance on geologic evidence. The sites available are too widely or otherwise inappropriately spaced to permit the mineral bodies to be outlined completely or the grade established throughout.

Reserves, Net: Includes all proved reserves associated with the company's net working interests. (See definition for Working Interest.)

Reserves, Proved (Oil and Gas): The estimated quantities of crude oil, natural gas, and natural gas liquids which geological and engineering data demonstrate with reasonable certainty to be recoverable in future years from known reservoirs under existing economic and operating conditions.

Reservoirs are considered proved if economic producibility is supported by one or more of: actual production; conclusive formation test; core analysis; and/or electric or other log interpretations. The area of a reservoir considered proved includes (1) that portion delineated by drilling and defined by gas-oil and/or oilwater contacts, if any; and (2) the immediately adjoining portions not yet drilled, but which can be reasonably judged as economically productive on the basis of available geological and engineering data. In the absence of information on fluid contacts, the lowest known structural occurrence of hydrocarbons controls the lower proved limited of the reservoir. 
Volumes of oil and gas placed in underground storage are not to be considered proved reserves, but should be classified as inventory.

Reserves that can be produced economically through application of improved recovery techniques (such as fluid injection) are included in the "proved" classification when successful testing by a pilot project, or the operation of an installed program in the reservoir, provides support for the engineering analysis on which the project or program was based.

Estimates of proved reserves do not include the following: (1) oil that may become available from known reservoirs but is classified separately as "indicated additional reserves;" (2) crude oil, natural gas, and natural gas liquids, the recovery of which is subject to reasonable doubt because of uncertainty as to geology, reservoir characteristics, or economic factors; (3) crude oil, natural gas, and natural gas liquids that may occur in undrilled prospects; and (4) crude oil, natural gas, and natural gas liquids that may be recovered from oil shales, coal, gilsonite and other such sources.

It is not necessary that production, gathering, or transportation facilities be installed or operative for a reservoir to be considered proved.

For natural gas, an appropriate reduction in the reservoir gas volume is made to cover the removal of the liquefiable portions of the gas and the exclusion of nonhydrocarbon gases where they occur in sufficient quantity to render the gas unmarketable. If the liquefiable portions of the gas are not separately estimated, they need not be separately stated for FRS reporting purposes.

Reservoir: A porous and permeable underground formation containing an individual and separate accumulation of producible hydrocarbons (oil and/or gas) that is confined by impermeable rock or water barriers and is characterized by a single natural pressure system.

Residual Fuel Oil: The heavier oils that remain after the distillate fuel oils and lighter hydrocarbons are distilled away in refinery operations and that conform to ASTM Specifications D396 and 975. Included are No. 5, a residual fuel oil of medium viscosity; Navy Special, for use in steam-powered vessels in government service and in shore power plants; No. 6, which includes Bunker C fuel oil, and is used for commercial and industrial heating, electricity generation, and to power ships.

Royalty: A contractual arrangement providing a mineral interest that gives the owner a right to a fractional share of production or proceeds therefrom, that does not contain rights and obligations of operating a mineral property and that is normally free and clear of exploration, developmental, and operating costs, except production taxes.

Short Ton: A unit of weight that equals 2,000 pounds.

Support Equipment and Facilities: These include, but are not limited to, seismic equipment, drilling equipment, construction and grading equipment, vehicles, repair shops, warehouses, supply points, camps, and division, district, or field offices.

Tangible Development Costs: Cost incurred during the development stage for access, mineral-handling, and support facilities having a physical nature. In mining, such costs would include tracks, lighting equipment, ventilation equipment, other equipment installed in the mine to facilitate the extraction of minerals, and supporting facilities for housing and care of work forces. In the oil and gas industry, tangible development costs would include well equipment (such as casing, tubing, pumping equipment, and well heads), as well as field storage tanks and gathering systems.

Tar Sands: Naturally occurring bitumen-impregnated sands that yield mixtures of liquid hydrocarbon and that require further processing other than mechanical blending before becoming finished petroleum products.

Timing Differences: Differences between the periods in which transactions affect taxable income and the periods in which they enter into the determination of pretax accounting income. Timing differences originate in one period and reverse or "turn around" in one or more subsequent periods. Some timing differences reduce income taxes that would otherwise be payable currently; others increase income taxes that would otherwise be payable currently.

Transfer Price: The monetary value assigned to products, services, or rights conveyed or exchanged between related parties, including those occurring between units of a consolidated entity.

Uncompleted Wells, Equipment, and Facilities Costs: The costs incurred to (1) drill and equip wells that are not yet completed and (2) acquire or construct equipment and facilities that are not yet completed and installed.

Undeveloped Property: Refers to a mineral property on which development wells or mines have not been drilled or completed to a point that would permit the production of commercial quantities of mineral reserves. 
Uranium Oxide: A yellow or brown powder produced from naturally occurring uranium minerals as a result of milling uranium ore or processing uranium-bearing solutions. Synonymous with "yellowcake," $\mathrm{U}_{3} \mathrm{O}_{8}$, or uranium concentrate.

Well: A hole drilled in the earth for the purpose of (1) finding or producing crude oil or natural gas; or (2) providing services related to the production of crude oil or natural gas.

Wells are classified as (1) oil wells; (2) gas wells; (3) dry holes; (4) stratigraphic test wells; or (5) service wells. The latter two types of wells are not counted for FRS reporting. Oil wells, gas wells, and dry holes are classified as exploratory wells or development wells. Exploratory wells are subclassified as (1) new-pool wildcats; (2) deeper-pool tests; (3) shallow-pool tests and (4) outpost (extension) tests. Well classifications reflect the status of wells after drilling has been completed.

- Completion. The term refers to the installation of permanent equipment for the production of oil or gas.

- Development Well. A well drilled within the proved area of an oil or gas reservoir to the depth of a stratigraphic horizon known to be productive.

- Dry Hole. An exploratory or development well found to be incapable of producing either oil or gas in sufficient quantities to justify completion as an oil or gas well.

- Exploratory Well. A well that is not a development well, a service well, nor a stratigraphic test as those items are defined elsewhere.
- Oil Well. A well completed for the production of crude oil from at least one oil zone or reservoir.

Wellhead Price: The value at the mouth of the well. In general, the wellhead price is considered to be the sales price obtainable from a third party in an arm's length transaction. Posted prices, requested prices, or prices as defined by lease agreements, contracts, or tax regulations should be used where applicable.

Working Interest: An interest in a mineral property that entitles the owner of that interest to all of a share of mineral production from the property, usually subject to a royalty.

A working interest permits the owner to explore, develop, and operate the property. The working interest owner bears the costs of exploration, development, and operation of the property and, in return, is entitled to a share of the mineral production from the property or to a share of the proceeds therefrom. It may be assigned to another party in whole or in part, or it may be divided into other special property interests.

- Gross Working Interest. The reporting company's working interest plus the proportionate share of any basic royalty interest or overriding royalty interest related to the working interest.

- Net Working Interest. The reporting company's working interest not including any basic royalty or overriding royalty interests. 


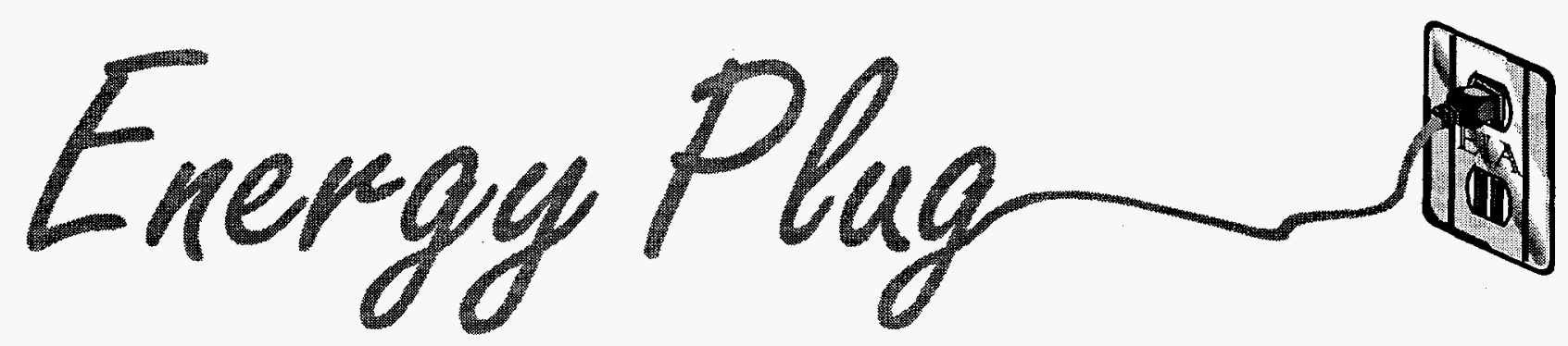

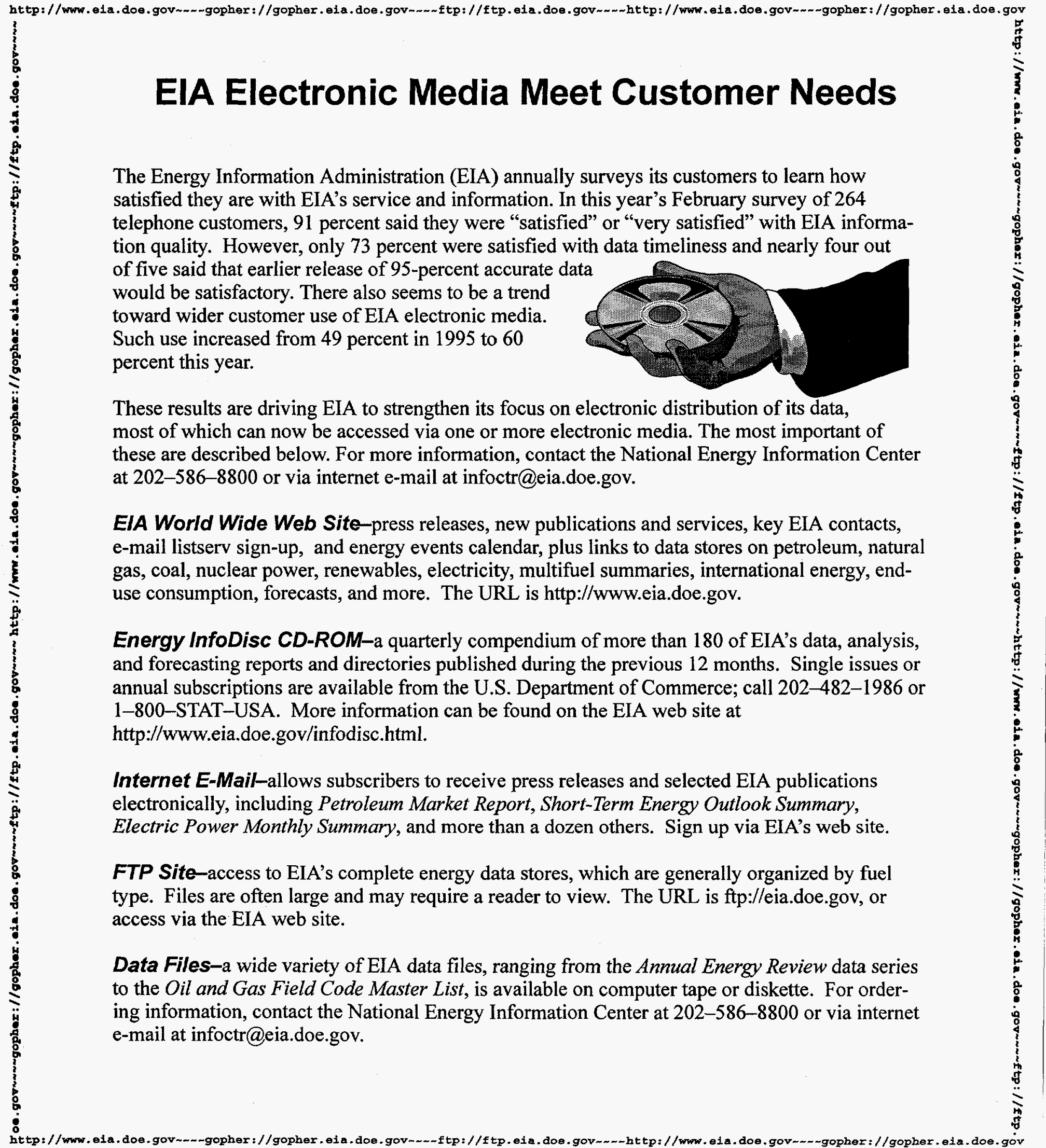

